I N T ER N ATIONAL MONETARY FUND

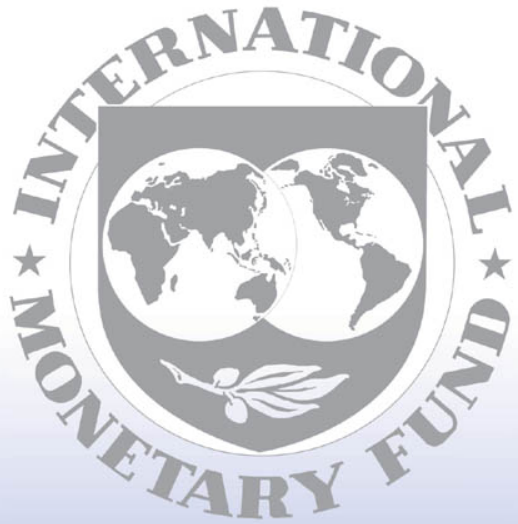

Staff

Country

Reports 


\section{Republic of Belarus: Report on Observance of Standards and Codes-Data Module, Response by the Authorities, and Detailed Assessments Using Data Quality Assessment Framework}

This Report on the Observance of Standards and Codes on the Data Module for the Republic of Belarus was prepared by a staff team of the International Monetary Fund as background documentation for the periodic consultation with the member country. It is based on the information available at the time it was completed on January 24, 2005. The views expressed in this document are those of the staff team and do not necessarily reflect the views of the government of the Republic of Belarus or the Executive Board of the IMF.

The Response by the Authorities on this report, and the Detailed Assessments Using the Data Quality Assessment Framework (DQAF) are also included.

The policy of publication of staff reports and other documents by the IMF allows for the deletion of market-sensitive information.

To assist the IMF in evaluating the publication policy, reader comments are invited and may be sent by e-mail to publicationpolicy@imf.org.

Copies of this report are available to the public from

International Monetary Fund $\bullet$ Publication Services

700 19th Street, N.W. • Washington, D.C. 20431

Telephone: (202) $6237430 \bullet$ Telefax: (202) 6237201

E-mail: publications@imf.org • Internet: http://www.imf.org

Price: $\$ 15.00$ a copy

\section{International Monetary Fund Washington, D.C.}


This page intentionally left blank

(C) International Monetary Fund. Not for Redistribution 
INTERNATIONAL MONETARY FUND

REPUBLIC OF BELARUS

\section{Report on the Observance of Standards and Codes (ROSC)—Data Module}

Prepared by the Statistics Department

Approved by Robert W. Edwards and Michael C. Deppler

January 24, 2005

The Report on the Observance of Standards and Codes (ROSC) data module provides an assessment of the Republic of Belarus's macroeconomic statistics against the recommendations of the Special Data Dissemination Standard (SDDS) complemented by an assessment of data quality based on the IMF's Data Quality Assessment Framework (DQAF July 2003). The DQAF lays out internationally accepted practices in statistics, ranging from good governance in data producing agencies to practices specific to datasets.

The datasets covered in this report are national accounts, consumer and producer price indices, government finance, monetary, and balance of payments statistics. The agencies that compile the datasets assessed in this report are the Ministry of Statistics and Analysis (Minstat), the Ministry of Finance (MoF), and the National Bank of the Republic of Belarus (NBRB).

The datasets to which this report pertains can be accessed in print and on the Internet as follows:

Minstat: http://president.gov.by/Minstat/en/main.html

MoF: $\quad$ http://ncpi.gov.by/minfin

NBRB: http://www.nbrb.by/engl/

This report is based on information provided by the Belarusian authorities prior to and during a staff mission from March 23-April 7, 2004 and publicly available information. The mission team was headed by Mr. Gérard G. Raymond and comprised Messrs. Roman Skarzynski and Samuele Rosa, Mmes. Rita Mesias and Shelley Winston (all Statistics Department), Mr. David Allen (Expert), and Ms. Claudia Fagbemi (Assistant). 
Abbreviations

I. Overall Assessment

II. Assessment by Agency and Dataset.

III. Recommendations

\section{Tables}

1. Data Quality Assessment Framework July 2003 - Summary Results. $\underline{8}$

2a. Assessment of Data Quality-Dimensions 0 and 1-Ministry of Statistics and Analysis.. $\underline{9}$

2b. Assessment of Data Quality-Dimensions 0 and 1 - Ministry of Finance ......................10

2c. Assessment of Data Quality —Dimensions 0 and $1-$ National Bank ..............................11

3a. Assessment of Data Quality_Dimensions 2 to 5-National Accounts ...........................12

3b. Assessment of Data Quality-Dimensions 2 to 5 - Consumer Price Index...................... $\frac{13}{14}$

3c. Assessment of Data Quality_Dimensions 2 to 5-Producer Price Index ......................... $\frac{14}{15}$

3d. Assessment of Data Quality-Dimensions 2 to 5 - Government Finance Statistics .........15

3e. Assessment of Data Quality_Dimensions 2 to 5-Monetary Statistics.........................16

3f. Assessment of Data Quality_Dimensions 2 to 5-Balance of Payments Statistics ..........17

\section{Appendix}

I. Table 4. Practices Compared to the SDDS Coverage, Periodicity, and Timeliness of Data. 
SNA 1993

COICOP

CPI

DQAF July 2003

GDP

GFS

GFSM 1986

GFSM 2001

IMF

ISIC

ITRS

MFSM

Minstat

$\mathrm{MoF}$

NBRB

PPI

ROSC

SDDS

\section{Abbreviations}

System of National Accounts 1993

Classification of Individual Consumption by Purpose

Consumer Price Index

Data Quality Assessment Framework, July 2003 version

Gross Domestic Product

Government Finance Statistics

A Manual of Government Finance Statistics 1986

Government Finance Statistics Manual 2001

International Monetary Fund

International Standard Industrial Classification

International Transactions Reporting System (Republic of Belarus)

Monetary and Financial Statistics Manual

Ministry of Statistics and Analysis of the Republic of Belarus

Ministry of Finance (Republic of Belarus)

National Bank of the Republic of Belarus

Producer Price Index

Report on the Observance of Standards and Codes

Special Data Dissemination Standard 


\section{OVERALl ASSESSMENT}

1. In the Republic of Belarus, the main agencies that compile statistics assessed in this report are the Ministry of Statistics and Analysis (Minstat) (national accounts, consumer price index (CPI), and producer price index (PPI)), the Ministry of Finance (MoF) (government finance statistics (GFS)), and the National Bank of the Republic of Belarus (NBRB) (monetary and balance of payments statistics). In the Republic of Belarus, in addition to these official statistics, numerous targets and forecasts are made by government authorities and other users. This Report on the Observance of Standards and Codes (ROSC) data module, which was prepared during March 23-April 7, 2004 assesses the quality of the above official statistics, not the targets or forecasts. The quality of the Republic of the Belarus's macroeconomic statistics has improved significantly in many areas in the last few years. The authorities have established a relatively good track record of implementing recommendations of past technical assistance in statistics and have demonstrated commitment to pursuing plans and programs to further improve their statistics.

Notwithstanding these improvements, the mission found that all statistical agencies should increase users' confidence in the accuracy and reliability of official statistics. As part of this process, the mission recommends that more detailed information should be disseminated on the revision policies and compilation practices of all datasets, especially for national accounts and GFS. This would help respond to needs raised by certain users contacted by the mission.

2. The Republic of Belarus has not yet subscribed to the SDDS, but a resolution of the Council of Ministers has expressed the Republic of Belarus's intention to do so. ${ }^{12}$ During the mission, the Minister of Finance, the Minister of Statistics and Analysis, and the First Deputy Governor of the NBRB, voiced their strong commitment for SDDS subscription. The authorities have started posting data and metadata on the Minstat, the MoF, and the NBRB web sites. Particularly, the Minstat has posted long-term time-series price indices on the Internet during the mission and the NBRB announced that it will post the international reserves and foreign currency liquidity (reserves template) by end April 2004. ${ }^{3}$ A preliminary review of the Republic of Belarus's observance of the SDDS (see Appendix I) has concluded that it meets or exceeds the specifications for coverage, periodicity, and the timeliness for all SDDS data categories, except for timeliness of national accounts, and the availability of the reserves template; the review did not cover the SDDS availability of advance release calendars, summary methodology statements, and a national summary data page. The remainder of this section presents the mission's main conclusions from applying the IMF's

\footnotetext{
${ }^{1}$ The Republic of Belarus subscribed to the SDDS on December 22, 2004. References to SDDS in this report are to the situation as of the time of the data ROSC mission.

2 Early in January 2004, the authorities conveyed the Resolution of the Council of Ministers "on cooperation between the Republic of Belarus and International Monetary Fund on the Special Data Dissemination Standard," expressing its intention in subscribing to the SDDS.

${ }^{3}$ The reserves template data were posted on the NBRB's web site on April 12, 2004.
} 
Data Quality Assessment Framework (DQAF July 2003) for six economic datasets. The presentation is done at the level of the DQAF's quality dimensions, by agency for the first two dimensions, and across datasets for the remaining four. ${ }^{4}$

3. Prerequisites of quality: The legal relations associated with the statistical activity of State statistical authorities, ministries, and other administrative authorities producing statistics in the Republic of Belarus are well covered by the Law on State Statistics. Nonetheless, for the MoF and the NBRB, the institutional responsibility for collecting, compiling, and disseminating government finance, monetary, and balance of payments statistics is not always clearly defined under the legal and institutional framework. The MoF's responsibility for collecting and compiling GFS is covered only through an internal provision and the dissemination of statistics is limited to the IMF departments, the Minstat, the NBRB, and other Belarusian agencies. The NBRB's statistical responsibilities, which were not completely covered in the Banking Code of the Republic of Belarus, are currently being addressed in the National Assembly. Among other prerequisites of quality,

confidentiality of individual respondents' data is well protected in current legislation but may need to be strengthened in regard to requesting consent from an entity for the disclosure of its information. Staff resources at the Minstat and the NBRB are mostly adequate, but are quantitatively inadequate for the compilation of GFS in the MoF. Recent new tasks in terms of SDDS subscription (external debt and reserves template) may also require additional training and staffing at the NBRB. All agencies demonstrate awareness of quality.

4. Assurances of integrity: All three agencies demonstrate professionalism; all provide guidelines on ethical conduct of their staff. The relevance of national accounts, CPI, and PPI is not systematically monitored. Fiscal data are widely available; however, the terms and conditions under which the MoF collects, compiles, and disseminates GFS are not publicly available.

5. Methodological soundness. All datasets are in stages of meeting internationally accepted methodological guidelines, but could come closer in certain areas. For national accounts, for example, concepts used in the Minstat's surveys generally accord with international standards; however, economic activity and product classifications do not yet meet international standards, and work is under way to progressively implement these international classifications. For the CPI, owner-occupied housing and own account consumption are excluded. For the PPI, service industries are excluded. For government finance, the scopes of the compiled finance statistics and budget system operations are incomplete - not all extrabudgetary operations are included. For monetary and balance of payments statistics, the classification by instrument does not include financial derivatives. In addition, the valuation of monetary gold in monetary statistics is recorded in the NBRB's account at the historical acquisition cost (transaction cost) and is revalued at irregular

\footnotetext{
${ }^{4}$ This data ROSC includes a general, but not detailed assessment of data sources used in compiling the national accounts. The aspects related to the liquidity of reserves assets and pledged and otherwise committed assets are also not covered in this report.
} 
intervals, as authorized by individual directives of the management of the NBRB. However, a decision has already been taken to revalue gold at market prices in monetary statistics beginning with data for April 2004, and to revise historical time series accordingly.

6. Accuracy and reliability. Some datasets receive high marks for accuracy and reliability, and the Republic of Belarus's statistical system has generally comprehensive and timely source data. However, in national accounts, further attention to measurement of the nonobserved economy would be desirable. Also, according to the Minstat, balance of payments inputs for national accounts are not timely enough. Also, in balance of payments source data, there are no distinct International Transactions Reporting System (ITRS) codes for financial transactions and related income on bonds and notes and on money market instruments. In addition, financial institutions' transactions in securities are calculated as residual after valuation and other changes. Measures taken in assessing and validating source data, intermediate data, and statistical outputs appear appropriate. However, the mission has concerns about the accuracy and reliability of actual data produced, particularly of the GDP and industrial and agricultural production data. The mission's focus did not involve an audit of sources used to compile national accounts statistics: if the basic inputs used in the statistical process are distorted, outputs will also be distorted, even if internationally recognized methodologies are applied. Thus, the mission recommended that all data producing agencies in the Republic of Belarus should enhance their data assessment and validation procedures, finding ways in the process of increasing users' confidence in the accuracy and reliability of official statistics.

7. Serviceability. Most datasets are generally consistent internally and over time and are available on a timely basis with good frequency. In general, timeliness and periodicity of the datasets meet or exceed SDDS requirements. The exception is the timeliness of the data on national accounts. Moreover, the statistical discrepancy is explicitly shown in GDP estimates at current prices but not in the constant price series. Also, there are significant differences between fiscal and monetary data on financing of central government, and neither the MoF nor the NBRB carry out a comprehensive reconciliation of both data sets. Revisions of quarterly national accounts were made from 1990 to 1999, but explanations were not published. Preliminary and revised data are not clearly identified in most datasets.

8. Accessibility. Monetary and balance of payments statistics are readily and conveniently available to the public. Nevertheless, the accessibility of statistics and assistance to users in national accounts, CPI, PPI, and GFS could be further improved. Metadata for all datasets need enhancement, especially for national accounts and GFS.

9. Section II of this ROSC data module provides a summary assessment by agency and dataset based on a four-part scale (see the footnote, Table 1). This is followed by staff recommendations in Section III. The authorities' response to this report and a volume of detailed assessments are presented in separate documents. 


\section{Assessment by AgenCy And Dataset}

10. Assessments of the quality of six macroeconomic datasets - national accounts, CPI, producer price index, government finance, monetary, and balance of payments statisticswere conducted using the DQAF July 2003. In this section, the results are presented at the level of the DQAF's elements, using a four-point scale (Table 1). Assessments of the prerequisites of data quality and the assurances of integrity (Dimensions " 0 " and " 1 " of the DQAF), are presented in Tables $2 \mathrm{a}, 2 \mathrm{~b}$, and $2 \mathrm{c}$. For each dataset, the assessment of methodological soundness, accuracy and reliability, serviceability, and accessibility (Dimensions " 2 " to " 5 " of the DQAF) are shown in Tables 3a-f. 
Table 1. Republic of Belarus: Data Quality Assessment Framework July 2003—Summary Results

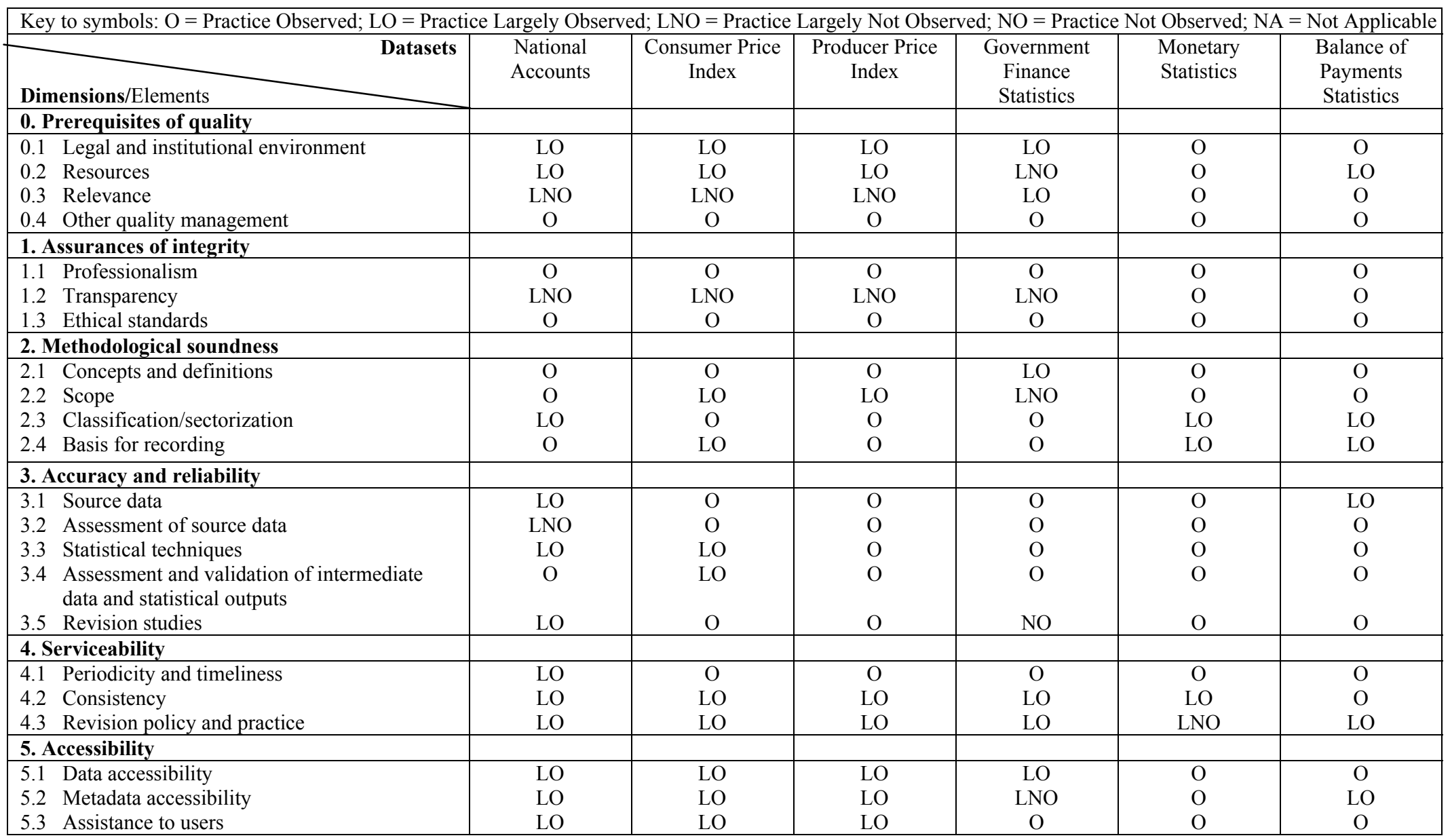

Practice observed: current practices generally in observance meet or achieve the objectives of DQAF internationally accepted statistical practices without any significant deficiencies. Practice largely observed: some departures, but these are not seen as sufficient to raise doubts about the authorities' ability to observe the DQAF practices. Practice largely not observed: significant departures and the authorities will need to take significant action to achieve observance. Practice not observed: most DQAF practices are not met. Not applicable: used only exceptionally when statistical practices do not apply to a country's circumstances. 
Table 2a. Republic of Belarus: Assessment of Data Quality_Dimensions 0 and 1-Ministry of Statistics and Analysis

\section{Prerequisites of quality}

Legal and institutional environment. The Law on State Statistics, 1997 specifies the procedure for organizing and coordinating State statistics, and governs legal relations associated with the statistical activity of State statistical authorities, ministries, and other administrative authorities that produce statistics. The Minstat prepares an annual coordinated statistical work plan and is responsible for setting standards for classifications and methods for compiling statistics. The Law guarantees the confidentiality of data used for compiling statistics. However, the Minstat needs to strengthen the law to guard against the disclosure of confidential information.

Resources. Staff resources are generally adequate. Computing needs and technology appear adequate for the CPI and PPI. However, the computing facilities for national accounts staff need improvement, and there are no provisions of emergency backup of data

Relevance. The relevance of national accounts, CPI, and PPI to users is not systematically monitored. An Inter-Agency Council has been established, comprising the heads of relevant departments and other government-related bodies. It takes account of government users' requirements, but mainly addresses methodological and priorities issues. Concerns expressed by some users concerning the accuracy and reliability of source data could be addressed more actively.

Other quality management. Other quality management tasks are facilitated by the Minstat's Department of Statistical Planning that coordinates all work associated with the improvement and maintenance of statistical quality. It makes studies and proposals regarding data quality for specific statistical activities, for example, pilot testing of surveys.

\section{Assurances of integrity}

Professionalism. Articles 4 and 10 of the Law on State Statistics highlight the Minstat's commitments to professionalism. Interference by any government authorities, officials, and other persons in the activity of the State statistical authorities is not permitted. Only statistical considerations are taken into account when determining data sources and methods. Recruitment and promotion of staff are based on expertise in statistics. The Minstat encourages research and analysis by specialists to maintain the Minstat's reputation for professionalism. Sources and methods are under the control of the Minstat. The Minstat is entitled to comment on misuse and misinterpretation of statistics, and exercises that right, as necessary.

Transparency is conveyed through publicizing the Law on State Statistics, publications, and metadata, including on the Minstat's web site. Advance notice is not given to the public about major changes in methodology, sources, and statistical techniques for compilation. Even though the Minstat's web site states that there is no internal governmental access to statistics prior to their release, summary annual national accounts data are made available to the government three months prior to their release to the public. All products of the Minstat are clearly identified as such. However, the users' perception is that major changes in methodology, source data, and statistical techniques are not provided. Serious efforts should be made to correct this perception.

Ethical standards. Ethical standards are detailed in articles 13 and 15 of the Law on State Statistics. Requirements regarding staff behavior are notified in the duty manual, which is provided to each staff member. The Law on Civil Service also provides guidelines on staff behavior including confidentiality and conflict of interest. This law was recently amended and training courses were arranged to inform staff about their responsibilities. 


\section{Prerequisites of quality \\ Legal and institutional environment. The MoF has a legal and institutional} environment that supports its responsibility for the compilation and dissemination of GFS and budget execution data. Although the responsibility for GFS

compilation is clearly specified in an internal provision of the MoF, the GFS dissemination is limited to the International Monetary Fund (IMF), the Ministry of Statistics and Analysis (Minstat), the National Bank of the Republic of Belarus (NBRB), and other agencies concerned. Data sharing and coordination among public institutions are adequate, though they can be improved. The confidentiality of data reported is protected by the Law on State Statistics, the State Secret Law and the Law on Civil Service. The budgetary legislation requires each

administrative authority to submit consolidated budgets to the MoF. Also, some administrative provisions support the collection and compilation of GFS.

Resources. Staff, computing, and financing resources are quantitatively inadequate for GFS compilation in the MoF. Additional computing resources are needed, and additional financial resources should be provided.

Relevance. The MoF does not undertake research to help identify new and emerging data requirements, but user requests for changes in the data compiled and disseminated are taken into account for future quality improvements. There are no surveys for obtaining feedback about the relevance and practical utility of fiscal data for analytical purposes, although some feedback is received from other government units.

Other quality management. Other quality management has been put in place to compile and disseminate fiscal data with increased coverage of institutions, timeliness, and periodicity, for example, the social protection funds are now included in the budget. Though there are no formal processes to assess the quality of the GFS, some monitoring mechanisms are in place to ensure consistency of data.

\section{Assurances of integrity}

Professionalism. The culture of professionalism is clearly recognized as essentia to the credibility of statistical results in the internal provisions of the $\mathrm{MoF}$ and in the Law on Civil Service. The choice and tenure of the compiling unit's head are based on independent process. Efforts are made to promote professionalism by sending staff to training courses abroad, contracting experts to provide on-the-job training, analytical work, publication of methodological papers, and organization of lectures and seminars. Professionalism is a key factor in the recruitment and promotion of staff. No evidence exists of political interference in the choice of data sources and statistical methods. The MoF is empowered to respond to misinterpretation/misuse of fiscal statistics.

Transparency. The public has unimpeded access to the budget legislation, and the broad legal framework for collection, compilation and dissemination of fiscal data. However, transparency is affected because the MoF does not make available, to the public, the terms and conditions under which the MoF collects, compiles, and disseminates GFS. No official agency outside of MoF has access to data prior to publication; however, this practice is not publicly announced. All GFS products that are disseminated clearly identify the producing agencies and data sources. Although explanatory notes are provided when the changes are introduced in publications, no advance notice is given to the public about major changes in the methodology or other relevant changes that materially affect GFS

Ethical standards. The ethical standards guiding staff behavior are the Law on Civil Service and the MoF's internal provisions about its functions and obligations. Staff in the MoF is generally aware of ethical provisions that regulate their work. A civil servant may face disciplinary, administrative, criminal, or other penalties for non-execution or improper execution of his official responsibilities, for violation of labor discipline, or violation of restrictions associated to the civil service. 
Table 2c. Republic of Belarus: Assessment of Data Quality_Dimensions 0 and 1 -National Bank of the Republic of Belarus

\section{Prerequisites of quality}

Legal and institutional environment. The NBRB's statistical responsibilities are defined in the Banking Code and the NBRB Statute. The NBRB's rights to collect statistical information are adequately defined, and the compilation of balance of payments data is listed among the NBRB's functions. The dissemination of these data to the public is not clearly mandated, and no responsibilities with regard to compiling and disseminating monetary statistics are stipulated. However, draft amendments to the Banking Code, which are expected to be enacted in the Spring 2004 session of the National Assembly, contain adequate references to the NBRB's rights and responsibilities with regard to the compilation and dissemination of both the balance of payments and monetary statistics. Data sharing and coordination among data-producing agencies are adequate, and sufficient safeguards exist to ensure data confidentiality.

Resources. Under normal circumstances, units compiling balance of payments and monetary statistics have adequate personnel and material resources, including sufficient computer equipment. However, there is some concern that the recent additional tasks related to the SDDS subscription (external debt framework and reserves template) may require additional training and resources. Some concerns relate to the continuing expansion of tasks of the Money and Credit Statistics Division (MCSD) to include a vast range of datasets not directly related to monetary statistics. As a result, staff resources may be inadequate to effectively handle the prospective tasks of implementing the new data presentation framework based on the Monetary and Financial Statistical Manual (MFSM) and establishing the system for the compilation of data on transactions and other flows.

Relevance. Regular formal consultations with official users of statistics are held in the framework of the Interagency Council of Statistics and the quarterly meetings on the directions of money and credit policy. Users' views are actively sought through informal channels, through contacts with academia, and through providing a contact person, an email address, and phone number in the NBRB's Bulletin of Banking Statistics and on the NBRB's web site. Data presentation formats are occasionally modified in response to users' requests.

Other quality management. The NBRB recognizes that official statistics must have the confidence of their users. Procedures are in place that focus on quality, for example, the design and development of the ITRS form, or plans for implementing the new framework for monetary statistics. Close statistical cooperation with the Central Bank of Russia provides additional stimulus for quality improvement.

\section{Assurances of integrity}

Professionalism. The statutory provisions under which the NBRB compiles monetary and balance of payments statistics are adequate to support its impartiality in conducting these functions. Staff involved in compiling monetary and balance of payments statistics is provided adequate professional independence and is given opportunities to enhance their professionalism through participation in external courses and on-the-job training. The choice of sources and statistical methods is determined solely by statistical considerations. Misinterpretations of monetary and balance of payments statistics are addressed through the NBRB's spokesperson. The NBRB seeks to prevent misinterpretation or misuse of its statistics by providing the metadata and explanatory methodological notes on its web site and in its publications.

Transparency. The legislation governing the NBRB's statistical activities is publicly available. There is no governmental access to statistics prior to their release and access to all users is provided simultaneously. This policy is publicly announced in the metadata that are posted on the NBRB's web site. The appropriate NBRB unit is clearly identified as a producer of data. Advance notice is given on major changes in methodology. Reasons for adjustments in time series data are explained in comments to corresponding tables.

Ethical standards. A Code of Professional Ethics of the Employee of the NBRB was introduced in April 2003. It includes a number of provisions on how to avoid conflict of interest. Each employee is required to know and follow this code. Copies of the code are easily available to the NBRB staff. 


\section{Methodological soundness}

Concepts and definitions. The national accounts are compiled according to the conceptual framework of the System of

National Accounts 1993 (SNA 1993).

Scope. All tables and accounts required by the Inter-Secretariat Working Group on National Accounts are compiled.

Quarterly estimates of GDP at constant prices by production and by expenditure are also published.

Classification/sectorization. Institutional units and transactions and other flows accord with the SNA 1993. Classifications do not yet meet international standard industrial classification (ISIC) and the central product classification (CPC), though work is under way to implement progressively international standards. Classification of individual consumption by purpose (COICOP) is used to classify household consumption and classification of functions of government (COFOG) is used for general government expenditures Basis of recording. Value added, and all components of GDP by expenditure, accord with international standards of valuation. Transactions are recorded on an accrual basis.

\section{Accuracy and reliability}

Source data. The data sources for national accounts are generally suitable for national accounts and available on a timely basis (apart from certain balance of payments components). The primary source is the enterprise survey. Response rates for surveys are very high. Validation methods appear satisfactory. Use is also made of data from various administrative sources.

Assessment of source data. Most surveys are fully enumerated. Sampling errors are calculated for the household survey, based on random sampling methods. Data used in the compilation of the national account are carefully assessed and the best available sources are used in compiling the accounts. However, the mission's view is that the national accounts source data, particularly on GDP and industrial and agricultural production data, are not fully accurate and reliable.

Statistical techniques for the compilation of GDP according to the production and expenditure approaches are generally satisfactory. Measurement of the nonobserved economy requires refinement.

Constant price estimation methods are generally satisfactory.

\section{Assessment and validation of}

intermediate data and statistical

outputs. Estimates are validated at all

stages of processing. A statistical

discrepancy is used to balance the two

GDP estimates after all major components

have been validated.

Revision studies. Studies of revisions

have been carried out on an occasional

basis.

\section{Serviceability}

Periodicity and timeliness. National accounts are disseminated quarterly (in conformity with the SDDS) but with a

longer delay than the one month

timeliness SDDS requirement

Consistency. Data are generally

consistent internally and over time. There is an exception regarding the treatment of the statistical discrepancy. This is explicitly shown in the current price estimates, while in constant price estimates, it is included in net exports. Following a study, revisions were made to national accounts data for 1990 to 1999 and these have been published on a consistent basis. The national accounts are consistent with other major statistical frameworks.

Revision policy and practice. There is an explicit revision policy, which is included in a published document and followed closely by staff. However, the annual accounts are not generally subject to further revision subsequent to the publication based on actual annual (as distinct from quarterly) data.

\section{Accessibility}

Data accessibility. National account statistics are disseminated in the publications with sufficient level of details, but few charts are included and no analytical comments are provided. Monthly GDP data are published for cumulative (year to date) period and not for individual months. However, quarterly discrete series are available. Data are released on a preannounced schedule and advance release calendars are posted on the web site. Statistics are released simultaneously to all users, except for prior governmental access to annual data (see Table 2a).

Metadata accessibility. Metadata are posted on the Minstat's web site in a format similar to the SDDS. Detailed metadata are published in the Methodological Guidelines that has a limited distribution. Publications show information about concepts and definitions, but very little information is available on sources and methods. A significant number of users were not satisfied with the metadata or its accessibility.

Assistance to users is in place and all statistical publications contain the name and telephone number of the main contact person for those statistics. However, some users are not completely satisfied with assistance provided, e.g,, obtaining official statistics is a long process, and responses from the Minstat are not very clear. 
Table 3b. Republic of Belarus: Assessment of Data Quality-Dimensions 2 to 5-Consumer Price Index

\begin{tabular}{|c|c|c|c|}
\hline 2. Methodological soundness & 3. Accuracy and reliability & 4. Serviceability & 5. Accessibility \\
\hline $\begin{array}{l}\text { Concepts and definitions. The CPI } \\
\text { follows the concepts and definitions and } \\
\text { the basis for recording of international } \\
\text { good practices. } \\
\text { Scope. The scope of the CPI includes } \\
\text { urban households whose major activity } \\
\text { involves an unincorporated business } \\
\text { activity, but only data on household } \\
\text { purchases and not their own-account } \\
\text { consumption are included. The CPI } \\
\text { includes } 377 \text { goods and services. Imputed } \\
\text { rents from owner-occupied dwellings and } \\
\text { sales of illegal market goods and services } \\
\text { are excluded. In addition, goods and } \\
\text { services produced for own final } \\
\text { consumption are not included in the CPI. } \\
\text { Classification/sectorization. The SNA } \\
\text { 1993 is followed to classify household } \\
\text { units, transactions and other monetary } \\
\text { flows. The classification and sectorization } \\
\text { used in the compilation of the CPI are in } \\
\text { broad conformity with internationally } \\
\text { accepted systems. COICOP guidelines are } \\
\text { used to classify consumption activities. } \\
\text { Basis for recording. The basis for } \\
\text { recording the CPI is market prices. } \\
\text { Weights are not applied to purchase of } \\
\text { existing durable goods, such as used cars. }\end{array}$ & $\begin{array}{l}\text { Source data provide an adequate basis to } \\
\text { compile the CPI. The data reasonably } \\
\text { approximate the definitions, scope, } \\
\text { classifications, valuation, and time of } \\
\text { recording. } \\
\text { Assessment of source data. Measures are } \\
\text { taken in the assessment of source data. } \\
\text { Information about sampling errors for } \\
\text { each survey conducted is monitored on a } \\
\text { monthly basis. } \\
\text { Statistical techniques are generally } \\
\text { sound. Weights are annually updated. } \\
\text { Assessment and validation of } \\
\text { intermediate data and statistical } \\
\text { outputs. Intermediate data and statistical } \\
\text { outputs are assessed and validated, but } \\
\text { control edits are not supported by } \\
\text { computer programs for assessing and } \\
\text { validating data. All verifications and } \\
\text { assessments are done manually. } \\
\text { Revision studies are routinely conducted, } \\
\text { primarily on weight updating. Findings } \\
\text { from revision studies are used to } \\
\text { minimize future errors. }\end{array}$ & $\begin{array}{l}\text { Periodicity and timeliness. The CPI is } \\
\text { disseminated monthly with a lag of } 12 \\
\text { days and, accordingly, exceeds the one } \\
\text { month SDDS timeliness requirements. } \\
\text { Consistency. There are no consistency } \\
\text { issues as the CPI is not calculated for } \\
\text { regions or population centers within the } \\
\text { Republic of Belarus, nor is it calculated } \\
\text { for a particular subgroup. Long-term time } \\
\text { series (base year 1990) exist for three } \\
\text { subgroups (food, non food, and services), } \\
\text { but are infrequently published. } \\
\text { Revision policy and practice. Revision } \\
\text { policy is known to data users. CPI data } \\
\text { are not revised once published. The index } \\
\text { weights of the CPI are updated annually. } \\
\text { Studies of the annual weight updating are } \\
\text { conducted, but are not disseminated. }\end{array}$ & $\begin{array}{l}\text { Data accessibility. An advance release } \\
\text { calendar is available on the Minstat's web } \\
\text { site. Data are simultaneously released to } \\
\text { all users. Data for the CPI are generally } \\
\text { accessible, but the infrequent publication } \\
\text { of long-term time-series data of five years } \\
\text { or longer, with a given reference base, } \\
\text { does not meet international good practices } \\
\text { for index publication. Users need to be } \\
\text { made aware of the difference between } \\
\text { fixed base period and previous period. } \\
\text { Relevant series are not disseminated in a } \\
\text { seasonally adjusted form, and there are no } \\
\text { plans to seasonally adjust the data. } \\
\text { Metadata accessibility. Metadata are } \\
\text { available on the Minstat's web site, but } \\
\text { only limited CPI methodology } \\
\text { descriptions are provided. There is no } \\
\text { published information in official } \\
\text { statistical publications on the survey } \\
\text { sources, such as the response rates, survey } \\
\text { monitoring, non-sampling errors, sample } \\
\text { frame, sample design, estimation, and } \\
\text { imputation techniques. } \\
\text { Assistance to users is made available by } \\
\text { facsimile, email, and internet address that } \\
\text { are provided on the inside of most price } \\
\text { statistics publications, along with the } \\
\text { contact name. The Minstat publishes a } \\
\text { comprehensive print catalog of its } \\
\text { publications. Nevertheless, users indicate } \\
\text { that their requests for data are not met in a } \\
\text { timely manner. }\end{array}$ \\
\hline
\end{tabular}


Table 3c. Republic of Belarus: Assessment of Data Quality_Dimensions 2 to 5-Producer Price Index

\begin{tabular}{|c|c|c|c|}
\hline 2. Methodological soundness & 3. Accuracy and reliability & 4. Serviceability & 5. Accessibility \\
\hline $\begin{array}{l}\text { Concepts and definitions. The } \\
\text { concepts and definitions for the PPI and } \\
\text { principles of national accounts broadly } \\
\text { follow internationally accepted good } \\
\text { practices. } \\
\text { Scope. The PPI scope covers total } \\
\text { industry and is provided for } 14 \text { main } \\
\text { branches. However, service industries } \\
\text { are excluded. Also, own-account } \\
\text { production and own-account dwellings } \\
\text { are not covered. } \\
\text { Classification/sectorization. The SNA } \\
\text { 1993 is followed in classifying } \\
\text { institutional units and transactions. At } \\
\text { the industrial detail, ISIC is used, while } \\
\text { the Statistical Classification of } \\
\text { Economic Activities in the European } \\
\text { Communities (NACE) is also used to } \\
\text { classify the principal economic activity } \\
\text { of enterprises. } \\
\text { Basis for recording. The basis for } \\
\text { recording the PPI is the valuation rule } \\
\text { used for valuing the output (for the } \\
\text { weights of the PPI) and the product } \\
\text { prices collected are based on } \\
\text { basic/producer prices. }\end{array}$ & $\begin{array}{l}\text { Source data. The PPI source data used } \\
\text { to construct the weights and prices are } \\
\text { sound and comprehensive. } \\
\text { Assessment of source data is routinely } \\
\text { conducted. Unusually large movements } \\
\text { in prices are traced back to the } \\
\text { enterprise, if warranted, for verification. } \\
\text { Post-enumeration checks are made, and } \\
\text { the index is revised back for two } \\
\text { months. } \\
\text { Statistical techniques employ sound } \\
\text { procedures. Adjustments to unit records } \\
\text { are made only when clearly warranted } \\
\text { and can be identified in the price } \\
\text { tabulations. Procedures for imputation } \\
\text { and adjustments for non-response are } \\
\text { soundly based. } \\
\text { Assessment and validation of } \\
\text { intermediate data and statistical } \\
\text { outputs. The PPI is checked and } \\
\text { assessed against the relevant } \\
\text { components of the CPI and national } \\
\text { accounts. } \\
\text { Revision studies are mainly conducted } \\
\text { on weight revisions. Findings from } \\
\text { these revision studies are used to } \\
\text { minimize future errors. }\end{array}$ & $\begin{array}{l}\text { Periodicity and timeliness. The PPI is } \\
\text { disseminated monthly with a lag of } 12 \\
\text { days and, accordingly, exceeds the one } \\
\text { month SDDS timeliness requirements. } \\
\text { Consistency. Long-term series (base } \\
\text { year 1990) exist, but are infrequently } \\
\text { published. PPI series are published for } \\
\text { industry and product classifications, } \\
\text { and these series are carefully checked } \\
\text { for internal consistency. } \\
\text { Revision policy and practice. Revision } \\
\text { policy is known to data users. } \\
\text { Preliminary data for the PPI are first } \\
\text { released, and, then, two months after } \\
\text { the PPI data become final. Revision } \\
\text { studies are conducted but are not } \\
\text { published in official statistical } \\
\text { publications. }\end{array}$ & $\begin{array}{l}\text { Data accessibility. An advance release } \\
\text { calendar is available on the Minstat's web } \\
\text { site. Data are released to all users } \\
\text { simultaneously. Data for the PPI are } \\
\text { generally accessible, but the infrequent } \\
\text { publication of long-term time-series data of } \\
\text { five years or greater, with a given reference } \\
\text { base, does not meet international best } \\
\text { practices for index publication. Users need to } \\
\text { be made aware of the difference between } \\
\text { fixed base period and previous period. } \\
\text { Relevant series are not disseminated in a } \\
\text { seasonally adjusted form, and there are no } \\
\text { plans to seasonally adjust the data. } \\
\text { Metadata accessibility. Metadata are } \\
\text { available on the Minstat's web site, but } \\
\text { limited PPI methodology descriptions are } \\
\text { provided. There is no published information } \\
\text { in official statistical publications on the } \\
\text { survey sources, such as the response rates, } \\
\text { survey monitoring, non-sampling errors, } \\
\text { sample frame, sample design, estimation, } \\
\text { and imputation techniques. } \\
\text { Assistance to users is available by } \\
\text { facsimile, email, and internet address that are } \\
\text { provided on the inside of most price statistics } \\
\text { publications, along with the contact name. } \\
\text { The Minstat publishes a comprehensive } \\
\text { catalog of publications. Nevertheless, users } \\
\text { indicate that their requests for data are not } \\
\text { met in a timely manner. }\end{array}$ \\
\hline
\end{tabular}

CInternational Monetary Fund. Not for Redistribution 
Table 3d. Republic of Belarus: Assessment of Data Quality_Dimensions 2 to 5-Government Finance Statistics

\begin{tabular}{|c|c|c|c|}
\hline 2. Methodological soundness & 3. Accuracy and reliability & 4. Serviceability & 5. Accessibility \\
\hline $\begin{array}{l}\text { Concepts and definitions of the fiscal data } \\
\text { are broadly consistent with the } \\
\text { recommendations of } A \text { Manual of } \\
\text { Government Finance Statistics 1986 } \\
\text { (GFSM 1986). The authorities have not yet } \\
\text { prepared a plan to migrate to Government } \\
\text { Finance Statistics Manual } 2001 \text { (GFSM } \\
\text { 2001). } \\
\text { Scope. Although the MoF maintains } \\
\text { records of all operations of the general } \\
\text { government units, the scopes of the GFS } \\
\text { and budget data are incomplete. Both do } \\
\text { not include some extrabudgetary } \\
\text { operations. } \\
\text { Classification/sectorization of GFS is } \\
\text { mostly in accordance with } \\
\text { recommendations of the GFSM } 1986 \text {. The } \\
\text { budgetary expenditures are classified by } \\
\text { institution and by function. } \\
\text { Basis for recording. Revenue, } \\
\text { expenditure, and financing in the GFS and } \\
\text { budgetary data are recorded on a cash } \\
\text { basis. However, the Treasury of the MoF } \\
\text { keeps records of expenses on an accrual } \\
\text { basis. Most transactions are shown on a } \\
\text { gross basis, in line with the GFSM } 1986 \text {. }\end{array}$ & $\begin{array}{l}\text { Source data cover detailed financial } \\
\text { information on all budgetary units and some } \\
\text { extrabudgetary funds. The general budget } \\
\text { classification of revenue, expenditure, and } \\
\text { financing is broadly aligned with the GFSM } \\
\text { 1986. Source data are reported in a timely } \\
\text { manner. } \\
\text { Assessment of source data. Some procedures } \\
\text { for assessment of source data are in place to } \\
\text { evaluate the accuracy of the budget execution } \\
\text { data (and some refinements are planned). } \\
\text { Statistical techniques. Fiscal data are based on } \\
\text { comprehensive information and no statistical } \\
\text { adjustments are carried out. Data on local } \\
\text { governments are based on comprehensive } \\
\text { information. Budget execution reports are also } \\
\text { based on comprehensive information. } \\
\text { Assessment and validation of intermediate } \\
\text { data and statistical outputs. Assessment and } \\
\text { validation of intermediate data are prepared } \\
\text { against accounting data and banking statements. } \\
\text { Cross-checking with the NBRB on changes in } \\
\text { deposits is performed every year. Also, the main } \\
\text { statistical outputs of the GFS are validated } \\
\text { against other macroeconomic statistics. All } \\
\text { discrepancies between GFS and intermediate } \\
\text { data are investigated. } \\
\text { Revision studies and analyses are not } \\
\text { conducted. }\end{array}$ & $\begin{array}{l}\text { Periodicity and timeliness. } \\
\text { General government operations are } \\
\text { disseminated quarterly with a lag } \\
\text { of one month. Central government } \\
\text { operations and debt are } \\
\text { disseminated monthly with a lag of } \\
\text { one month. Accordingly, the } \\
\text { periodicity and timeliness of } \\
\text { general government operations and } \\
\text { central government debt exceed } \\
\text { the SDDS requirements. } \\
\text { Consistency. Statistics are } \\
\text { consistent within the dataset, over } \\
\text { a reasonable period of time, but } \\
\text { not always with those data } \\
\text { obtained through other data } \\
\text { sources and/or statistical } \\
\text { frameworks; e.g. comprehensive } \\
\text { reconciliation with monetary data } \\
\text { is not carried out. } \\
\text { Revision policy and practice. } \\
\text { The annual GFS published for the } \\
\text { first time are preliminary, and final } \\
\text { data are published following } \\
\text { revisions. Revisions are completed } \\
\text { when all institutions provide } \\
\text { revised data. Preliminary and final } \\
\text { data are adequately noted in } \\
\text { publications. Both are } \\
\text { disseminated with the same level } \\
\text { of detail and through the same } \\
\text { media. The revision policy is not } \\
\text { publicized. }\end{array}$ & $\begin{array}{l}\text { Data accessibility is affected because the } \\
\text { detailed underlying data are not provided. } \\
\text { The presentation of fiscal data does facilitate } \\
\text { analysis. The main statistical publication of } \\
\text { the MoF is a table compiled in preparation } \\
\text { for SDDS subscription. Fiscal data are } \\
\text { disseminated according to a preannounced } \\
\text { calendar. Fiscal data are made available to } \\
\text { all users simultaneously. The authorities } \\
\text { indicate that nonpublished, nonconfidential, } \\
\text { and disaggregated data are made available } \\
\text { upon request. The availability of } \\
\text { nonpublished data and the terms and } \\
\text { conditions under which such data are made } \\
\text { available are not publicized. } \\
\text { Metadata accessibility. The concepts, } \\
\text { scope, classifications, basis of recording, } \\
\text { data sources, and statistical methods for } \\
\text { budget data are documented as internal } \\
\text { provisions in the MoF. The same } \\
\text { documentation is not provided for GFS. GFS } \\
\text { and detailed budgetary metadata are not } \\
\text { accessible to the users. } \\
\text { Assistance to users is provided by } \\
\text { publicizing the contact person's name, an } \\
\text { email address and telephone number on the } \\
\text { MoF's web site. }\end{array}$ \\
\hline
\end{tabular}


Table 3e. Republic of Belarus: Assessment of Data Quality-Dimensions 2 to 5-Monetary Statistics

\begin{tabular}{|c|c|c|c|}
\hline 2. Methodological soundness & 3. Accuracy and reliability & 4. Serviceability & 5. Accessibility \\
\hline $\begin{array}{l}\text { Concepts and definitions. The analytical } \\
\text { framework used for compiling monetary } \\
\text { statistics reflects concepts and definitions } \\
\text { that are, in general, consistent with the } \\
\text { Monetary and Financial Statistical Manual } \\
\text { MFSM. } \\
\text { Scope. The scope of monetary statistics is } \\
\text { consistent with the guidelines of the MFSM } \\
\text { and covers all resident depository } \\
\text { corporations, including those in the process } \\
\text { of liquidation. } \\
\text { Classification/sectorization. } \\
\text { Classification and sectorization principles } \\
\text { follow the guidelines of the } M F S M \text {, except } \\
\text { for the treatment of financial derivatives, } \\
\text { which are recorded as off-balance sheet } \\
\text { items and excluded from statistics. } \\
\text { Basis for recording. The accounting rules } \\
\text { are consistent with the } M F S M \text { guidelines. } \\
\text { Transactions are recorded on an accrual } \\
\text { basis, and accrued interest is incorporated } \\
\text { into the outstanding amount of the } \\
\text { underlying financial asset or liability. } \\
\text { Contrary to the } M F S M \text { guidelines, however, } \\
\text { monetary gold is valued at historic } \\
\text { acquisition cost rather than at market prices. } \\
\text { (The NBRB has decided to apply market } \\
\text { price valuation of gold in its monthly } \\
\text { monetary statistics beginning with data for } \\
\text { April } 2004 \text {, and to revise historical data } \\
\text { accordingly.) }\end{array}$ & $\begin{array}{l}\text { Source data are balance sheet items of } \\
\text { depository corporations and } \\
\text { supplementary information from banks } \\
\text { and the IMF. These data are timely and } \\
\text { provide a reasonably good } \\
\text { approximation of the concepts, } \\
\text { definitions, scope, classifications, and } \\
\text { recording principles for compiling } \\
\text { sound monetary statistics. } \\
\text { Assessment of source data. } \\
\text { Compilers of monetary statistics } \\
\text { routinely assess source data and initiate } \\
\text { their modifications, such as changes in } \\
\text { charts of accounts, if needed for } \\
\text { improvements in statistical outputs. } \\
\text { Statistical techniques. The } \\
\text { compilation of monetary statistics is, to } \\
\text { a great extent, automated, which } \\
\text { minimizes the processing time and } \\
\text { errors. } \\
\text { Assessment and validation of } \\
\text { intermediate data and statistical } \\
\text { outputs. Intermediate results are } \\
\text { routinely validated against other reports } \\
\text { available. } \\
\text { Revision studies are periodically } \\
\text { carried out and used internally to } \\
\text { inform statistical processes. }\end{array}$ & $\begin{array}{l}\text { Periodicity and timeliness. } \\
\text { Periodicity is monthly and timeliness is } \\
\text { two weeks, which meet or-for the } \\
\text { analytical accounts of the banking } \\
\text { sector-exceed the timeliness } \\
\text { prescribed in the SDDS. } \\
\text { Consistency. Statistics are reasonably } \\
\text { consistent within the datasets and over } \\
\text { a reasonable period of time. Consistent } \\
\text { time series are available since } 1996 \text {. } \\
\text { Intermediate data are reconciled with } \\
\text { balance of payments and international } \\
\text { investment position (IIP), and } \\
\text { reconciliation with GFS is not carried } \\
\text { out. } \\
\text { Revision policy and practice. Monthly } \\
\text { data are considered preliminary and } \\
\text { subject to revisions for one quarter after } \\
\text { publication, and end-of-year data for } \\
\text { six months after publication. This data } \\
\text { revision policy is publicized on the } \\
\text { NBRB's web site. Contrary to } \\
\text { internationally accepted standards, } \\
\text { preliminary and revised data are not } \\
\text { clearly identified as such. In addition, } \\
\text { revisions are explained in footnotes, but } \\
\text { no revision studies are publicized. }\end{array}$ & $\begin{array}{l}\text { Data accessibility. Data are } \\
\text { disseminated, in hard copy, in the } \\
\text { monthly Bulletin of Banking Statistics } \\
\text { and the bi-weekly Bankauski Vesnik in } \\
\text { Russian, while the Bulletin of Banking } \\
\text { Statistics in English is available } \\
\text { quarterly. Downloadable data in Excel } \\
\text { are posted on the NBRB's web site in } \\
\text { Russian. An advance release calendar is } \\
\text { published in the Bulletin of Banking } \\
\text { Statistics and is posted on the web site. } \\
\text { Data are released simultaneously to all } \\
\text { users. This policy is publicized on the } \\
\text { NBRB's web site. Unpublished and } \\
\text { nonconfidential data are made available } \\
\text { free of charge, upon request. } \\
\text { Metadata accessibility. A } \\
\text { methodological commentary is } \\
\text { published in the Bulletin of Banking } \\
\text { Statistics and on the web site. Metadata } \\
\text { are posted on the web site in SDDS- } \\
\text { based format. However, the description } \\
\text { of accounting and valuation rules needs } \\
\text { improvement. } \\
\text { Assistance to users. The name and } \\
\text { phone number for contact person are } \\
\text { provided in the Bulletin of Banking } \\
\text { Statistics and-including email and fax } \\
\text { number-on the web site. }\end{array}$ \\
\hline
\end{tabular}

(C) International Monetary Fund. Not for Redistribution 


\begin{tabular}{|c|c|c|c|}
\hline 2. Methodological soundness & 3. Accuracy and reliability & 4. Serviceability & 5. Accessibility \\
\hline $\begin{array}{l}\text { Concepts and definitions. } \\
\text { Balance of payments broadly follows } \\
\text { the concepts and definitions set out in } \\
\text { the IMF's Balance of Payments } \\
\text { Manual, fifth edition (BPM5). } \\
\text { Scope. The scope is broadly consistent } \\
\text { with internationally accepted standards, } \\
\text { guidelines, or good practices. } \\
\text { Classification/sectorization } \\
\text { systems used are broadly consistent } \\
\text { with internationally accepted standards, } \\
\text { guidelines, or good practices. However, } \\
\text { financial derivatives are not included. } \\
\text { Basis for recording. The basis for } \\
\text { recording flows and stocks mostly } \\
\text { follows international guidelines. } \\
\text { However, income account is not fully } \\
\text { on an accrual basis. Grossing/netting } \\
\text { procedure follows } B P M 5 \text { guidelines. }\end{array}$ & $\begin{array}{l}\text { Source data are collected from } \\
\text { comprehensive data collection } \\
\text { programs that take into account } \\
\text { country-specific conditions. No distinct } \\
\text { ITRS codes are available for income on } \\
\text { bonds and notes and on money market } \\
\text { instruments. } \\
\text { Assessment of source data. Regular } \\
\text { assessment and validation of source and } \\
\text { intermediate data are undertaken. } \\
\text { Statistical techniques are sound and } \\
\text { consistent with international practices, } \\
\text { except for data on bank's transactions } \\
\text { in securities that are derived residually. } \\
\text { Assessment and validation of } \\
\text { intermediate data and statistical } \\
\text { outputs. Intermediate results and } \\
\text { statistical outputs are regularly assessed } \\
\text { and validated. } \\
\text { Revision studies. Studies and analyses } \\
\text { of revisions are carried out routinely } \\
\text { and used to inform statistical processes, } \\
\text { in particular regarding merchandise } \\
\text { trade data. }\end{array}$ & $\begin{array}{l}\text { Periodicity and timeliness. The } \\
\text { quarterly balance of payments are } \\
\text { disseminated with a lag of one quarter } \\
\text { and meet the SDDS requirements. } \\
\text { Consistency. Data are consistent } \\
\text { internally and over time, and are } \\
\text { reconciled with merchandise trade } \\
\text { statistics and the national accounts. } \\
\text { Data are also consistent with the } \\
\text { external debt and international } \\
\text { investment position statistics as they } \\
\text { result from the same sources. } \\
\text { Revision policy and practice. The } \\
\text { revision policy is well established and } \\
\text { transparent; tables identifying the cause } \\
\text { of revisions and providing a } \\
\text { comparison of initial and revised } \\
\text { estimates are published each quarter. } \\
\text { The impact of methodological changes } \\
\text { is explained to data users. The } \\
\text { disseminated tables do not distinguish } \\
\text { between preliminary, revised, and final } \\
\text { data. }\end{array}$ & $\begin{array}{l}\text { Data accessibility. Balance of } \\
\text { payments statistics are accessible on the } \\
\text { NBRB's web site and are released } \\
\text { simultaneously to all users according to } \\
\text { a pre-announced schedule. The bulletin } \\
\text { on Quarterly Balance of Payments } \\
\text { Statistics provides very comprehensive } \\
\text { tables and analysis of external } \\
\text { developments, at different levels of } \\
\text { detail. } \\
\text { Metadata accessibility. Metadata are } \\
\text { accessible in the form of internet based } \\
\text { SDDS formats, methodological notes in } \\
\text { the quarterly bulletin, and dedicated } \\
\text { boxes in different issues of the } \\
\text { quarterly bulletin on methodological } \\
\text { changes. (A comprehensive } \\
\text { documentation on data source, concepts } \\
\text { and definitions, and methodology is } \\
\text { under preparation.) } \\
\text { Assistance to users. Prompt assistance } \\
\text { to users is available on the NBRB's } \\
\text { web site. Staff or department contact } \\
\text { information is available on all } \\
\text { dissemination formats. }\end{array}$ \\
\hline
\end{tabular}




\section{RECOMMENDATIONS}

11. Based on the review of the Republic of Belarus's statistical practices, discussions with the data producing agencies, and responses from data users (see Appendix III of the Detailed Assessments volume), the mission has a set of recommendations. They are designed to increase further the Republic of Belarus's adherence to internationally accepted statistical practices and would, in the mission's view, enhance the analytical usefulness of the Republic of Belarus's statistics. Some additional technical suggestions are included in the Detailed Assessments volume.

\section{Cross-cutting Recommendations}

\section{High priority}

- $\quad$ Following the authorities' decision to subscribe to SDDS, continue preparatory steps for this subscription.

- $\quad$ Establish broadly based advisory committees representative of various groups of users.

- Conduct regular users surveys to determine if the statistical agencies are meeting the needs of users.

- $\quad$ Provide more detailed metadata and methodological descriptions in statistical publications and on the three institutions' web sites.

- Announce major changes in methodology in advance of the publication of the revised data.

- Improve public awareness of statistics producing agencies, and user understanding of official data.

- $\quad$ Develop improved back-up arrangements for storage of data, including off-site storage.

- Clearly mark data that are preliminary or revised.

- $\quad$ Conduct and publicize revision studies.

\section{National Accounts}

\section{High priority}

- $\quad$ Commence negotiations between the Minstat and the NBRB with the aim of improving the timeliness of the balance of payments data supplied to the Minstat for the quarterly national accounts.

- $\quad$ Review the quality of the monthly industrial production indices and publish them on a standard reference base.

- Give priority attention to the implementation of the General Classification of Types of Economic Activity (OKED) and the central product classification.

- Document and disseminate explanations between the Ministry of Economy's targets and the Minstat's actual GDP statistics. 


\section{Other recommendations}

- $\quad$ Strengthen procedures to guard against the disclosure of confidential information.

- $\quad$ Provide improved computing facilities for national accounts staff.

- $\quad$ Provide explanations on the differences between the constant price estimates based on previous period and those on a fixed base period to users.

- $\quad$ Undertake analyses of quarterly and annual trends in the statistical discrepancy as a means of identifying error sources and biases that require attention.

\section{Price Indices}

\section{High priority}

- $\quad$ Develop a range of control edits supported by computer programs for verification of data, and identification of errors.

- $\quad$ Publish long-term time-series more frequently.

- $\quad$ Provide explanations to users on the differences between price indices based on previous period and those on a fixed base period.

\section{Other recommendations}

- $\quad$ Strengthen procedures to guard against the disclosure of confidential information.

- Examine the desirability of including owner-occupied housing imputations in the CPI.

- $\quad$ Include net purchases of second-hand goods, such as cars, in the CPI.

- Include goods and services produced for own final consumption in the CPI.

- Include service industries to achieve a broader coverage of the PPI.

- Review the possibility of imputations on owner-account production and owneroccupied dwellings for the PPI.

- $\quad$ Produce and disseminate seasonally adjusted data.

- $\quad$ Provide requested data in a more timely basis.

\section{Government Finance Statistics}

High priority

- $\quad$ Compile and disseminate GFS for the consolidated central government and the general government including all budgetary, social security funds, and extrabudgetary operations using the classification determined by international standards.

- $\quad$ Disseminate on MoF's web site the GFS compiled and published in the IMF's International Financial Statistics (IFS) and Government Finance Statistics Yearbook (GFSY).

- Increase staff resources and provide more computing and financing resources for GFS compilation in the MoF. 
- $\quad$ Coordinate with the NBRB to carry out a detailed reconciliation of fiscal data on bank financing with monetary data on changes in net claims on government.

\section{Other recommendations}

- $\quad$ Improve the presentations of disseminated GFS to include additional breakdowns and time series.

- $\quad$ Establish a plan and timetable for adopting the GFSM 2001; commence relevant training; and start recording government transaction both on a cash and on an accrual basis.

\section{Monetary Statistics}

\section{High Priority}

- $\quad$ Carry out statistical adjustments to monthly data to revalue monetary gold at market prices, with a contra entry in revaluation accounts.

- Incorporate data on financial derivatives in the statistics, providing appropriate lines both in assets and liabilities.

- Coordinate with the MoF to carry out a detailed reconciliation of monetary data on changes in net claims on government with fiscal data on bank financing.

\section{Other recommendations}

- $\quad$ Enhance the description of methodology provided to the users to include more information on the recording basis and valuation rules.

\section{Balance of Payments Statistics}

\section{High priority}

- Introduce the functional category of financial derivatives in the standard balance of payments presentation.

- Calculate financial transactions in securities from changes in stocks independently, and derive valuation and other changes as a residual.

- $\quad$ Add separate codes for income on bonds and notes, and money market instruments.

- $\quad$ Calculate income on bank's security holdings on an accrual basis.

- $\quad$ Establish a survey to collect data on other sectors' non guaranteed debt on an accrual basis. 
Table 4. Republic of Belarus: Practices Compared to the SDDS Coverage, Periodicity, and Timeliness of Data

\begin{tabular}{|c|c|c|c|c|c|c|}
\hline \multirow[b]{2}{*}{ SDDS Data Category } & \multirow{2}{*}{$\begin{array}{l}\text { Coverage } \\
\text { (meets SDDS } \\
\text { requirement) }\end{array}$} & \multicolumn{2}{|c|}{ Periodicity } & \multicolumn{2}{|c|}{ Timeliness } & \multirow[b]{2}{*}{ Comments } \\
\hline & & SDDS & $\begin{array}{c}\text { Republic of } \\
\text { Belarus }\end{array}$ & SDDS & $\begin{array}{l}\text { Republic of } \\
\text { Belarus }\end{array}$ & \\
\hline \multicolumn{7}{|l|}{ Real Sector } \\
\hline National accounts & Yes & Q & Q & Q & $105 \mathrm{D}$ & $\begin{array}{l}\text { Timeliness does not meet SDDS } \\
\text { requirements. }\end{array}$ \\
\hline $\begin{array}{l}\text { Production } \\
\text { index/indices }\end{array}$ & Yes & M & $\mathrm{M}$ & $\begin{array}{c}6 \mathrm{~W} \\
(1 \mathrm{M} \\
\text { encouraged }) \\
\end{array}$ & $2 \mathrm{~W}$ & $\begin{array}{l}\text { Timeliness exceeds SDDS } \\
\text { requirements. }\end{array}$ \\
\hline Employment & Yes & Q & $\mathrm{M}$ & $\mathrm{Q}$ & $\mathrm{M}$ & $\begin{array}{l}\text { Periodicity and timeliness exceed } \\
\text { SDDS requirements. }\end{array}$ \\
\hline \multirow{2}{*}{$\begin{array}{l}\text { Unemployment } \\
\text { Wages/Earnings }\end{array}$} & Yes & Q & M & Q & M & $\begin{array}{l}\text { Periodicity and timeliness exceed } \\
\text { SDDS requirements. }\end{array}$ \\
\hline & Yes & Q & $\mathrm{M}$ & Q & $\mathrm{M}$ & $\begin{array}{l}\text { Periodicity and timeliness exceed } \\
\text { SDDS requirements. }\end{array}$ \\
\hline \multirow{2}{*}{$\begin{array}{l}\text { Consumer price index } \\
\text { Producer price index }\end{array}$} & Yes & M & $\mathrm{M}$ & $\mathrm{M}$ & $12 \mathrm{D}$ & $\begin{array}{l}\text { Timeliness exceeds SDDS } \\
\text { requirements. }\end{array}$ \\
\hline & Yes & M & M & $\mathrm{M}$ & $12 \mathrm{D}$ & $\begin{array}{l}\text { Timeliness exceeds SDDS } \\
\text { requirements. }\end{array}$ \\
\hline \multicolumn{7}{|l|}{ Fiscal sector } \\
\hline $\begin{array}{l}\text { General government } \\
\text { operations }\end{array}$ & Yes & $\mathrm{A}$ & Q & $2 \mathrm{Q}$ & $\mathrm{M}$ & $\begin{array}{l}\text { Periodicity and timeliness exceed } \\
\text { SDDS requirements. }\end{array}$ \\
\hline $\begin{array}{l}\text { Central government } \\
\text { operations }\end{array}$ & Yes & $\mathrm{M}$ & $\mathrm{M}$ & $\mathrm{M}$ & $\mathrm{M}$ & \\
\hline $\begin{array}{l}\text { Central government } \\
\text { debt }\end{array}$ & Yes & $\mathrm{Q}$ & $\mathrm{M}$ & Q & $\mathrm{M}$ & $\begin{array}{l}\text { Periodicity and timeliness exceed } \\
\text { SDDS requirements. }\end{array}$ \\
\hline \multicolumn{7}{|l|}{ Financial sector } \\
\hline $\begin{array}{l}\text { Analytical accounts of } \\
\text { the banking sector }\end{array}$ & Yes & $\mathrm{M}$ & $\mathrm{M}$ & $\mathrm{M}$ & $2 \mathrm{~W}$ & Data are disseminated weekly. \\
\hline $\begin{array}{l}\text { Analytical accounts of } \\
\text { the central bank }\end{array}$ & Yes & $\begin{array}{l}\mathrm{M}(\mathrm{W} \\
\text { recom- } \\
\text { mended })\end{array}$ & M & $\begin{array}{c}2 \mathrm{~W}(1 \mathrm{~W} \\
\text { encouraged })\end{array}$ & $2 \mathrm{~W}$ & Data are disseminated daily. \\
\hline Interest rates & Yes & D & $\mathrm{D}$ & $\mathrm{D}$ & $\mathrm{D}$ & \\
\hline Stock market & $\cdots$ & $\mathrm{D}$ & $\cdots$ & $\mathrm{D}$ & $\cdots$ & $\begin{array}{l}\text { A stock market exists in The } \\
\text { Republic of Belarus but the } \\
\text { volumes of equities traded are } \\
\text { minimal. }\end{array}$ \\
\hline \multicolumn{7}{|l|}{ External sector } \\
\hline Balance of payments & Yes & Q & Q & Q & Q & \\
\hline Official reserve assets & Yes & $\begin{array}{c}\mathrm{M}(W \\
\text { recom- } \\
\text { mended })\end{array}$ & $\mathrm{W}$ & $\mathrm{W}$ & $\mathrm{W}$ & \\
\hline Reserves template & No & $\mathrm{M}$ & $\ldots$ & $\mathrm{M}$ & $\ldots$ & Data are not yet available. \\
\hline Merchandise trade & Yes & $\mathrm{M}$ & $\mathrm{M}$ & $\begin{array}{c}8 \mathrm{~W}(4-6 \mathrm{~W} \\
\text { encouraged })\end{array}$ & $7 \mathrm{~W}$ & $\begin{array}{l}\text { Timeliness exceeds SDDS } \\
\text { requirements. }\end{array}$ \\
\hline $\begin{array}{l}\text { International } \\
\text { investment position }\end{array}$ & Yes & $\begin{array}{c}\text { A }(Q \\
\text { recom- } \\
\text { mended })\end{array}$ & Q & $\begin{array}{c}\text { 3Q }(1 Q \\
\text { encouraged) }\end{array}$ & $1 \mathrm{Q}$ & $\begin{array}{l}\text { Prescribed breakdown of } \\
\text { components does not appear to } \\
\text { be available. }\end{array}$ \\
\hline External debt & $\ldots$ & $\mathrm{Q}$ & Q & Q & Q & \\
\hline Exchange rates & Yes & $\mathrm{D}$ & $\mathrm{D}$ & $\ldots$ & $\ldots$ & \\
\hline $\begin{array}{l}\text { Addendum: } \\
\text { Population }\end{array}$ & $\cdots$ & A & $\cdots$ & $\cdots$ & $\cdots$ & \\
\hline
\end{tabular}

Note: Periodicity and timeliness: (D) daily; (W) weekly or with a lag of no more than one week from the reference date or the closing of the reference week; (M) monthly or with a lag of no more than one month; (Q) quarterly or with a lag of no more than one quarter; (A) annually; (NA) not available; and (...) not applicable. 
INTERNATIONAL MONETARY FUND

REPUBLIC OF BELARUS

Report on the Observance of Standards and Codes-Data Module Response by the Authorities

January 24, 2005

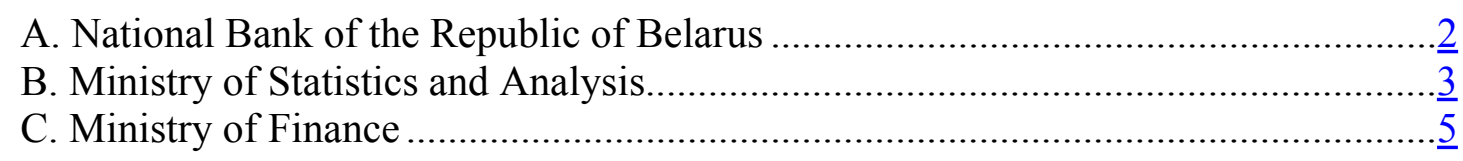

CInternational Monetary Fund. Not for Redistribution 
This document provides the response by the Belarusian authorities to the data module of the Report on Standards and Codes (ROSC) following the mission that took place during March 23-April 7, 2004. It was prepared by the National Bank of the Republic of Belarus (NBRB), the Ministry of Statistics and Analysis (Minstat), and the Ministry of Finance (MoF). Several of the mission's recommendations have been already implemented, including substantial work for the Republic of Belarus's subscription to the Special Data Dissemination Standards. 5

\section{A. National Bank of the Republic of Belarus}

The National Bank of the Republic of Belarus (NBRB) agrees on the whole with the evaluation of monetary statistics and balance of payments statistics stated in the Report on the Observance of Standards and Codes (ROSC) and currently remedied the indicated deficiencies. At the same time, the majority of recommendations stipulated in the ROSC have been already fulfilled.

In particular, the following steps were taken regarding monetary statistics:

1. Since January 1, 2004, monetary gold is valued at market prices. At present, the National Bank of the Republic of Belarus adjusts this indicator for the previous periods.

2. At present, the issue of accounting financial derivatives on the NBRB's and banks' balance sheet accounts by compilation of monetary surveys is being examined.

3. In July 2004, the National Bank of the Republic of Belarus carried out detailed comparison of monetary data with regard to changes in net claims to the Government with tax and budget data on banking financing. The IMF was informed on the results of this comparison.

The following steps were taken concerning balance of payments statistics:

1. Starting from the publication of the BOP for January-March 2004, the section "Financial Derivatives" was introduced in its presentation. The BOP presentation for the previous periods was revised.

2. The methodology of estimating flow changes of the banking sector's securities (assets, portfolio investments) based on the stocks and monthly average exchange rates was developed. These flow changes are calculated independently and the valuation and other changes are derived as a residual value. Mentioned methodology

\footnotetext{
${ }^{5}$ The Republic of Belarus subscribed to the Special Data Dissemination Standards on December 22, 2004.
} 
was used to estimate BOP data for January-March 2004. Based on this methodology the data for previous periods were revised.

3. Within current procedures of amending banks' reports, the NBRB plans to introduce separate codes for income on bonds, notes and money market instruments into the ITRS with a view to get information with necessary breakdown starting from the data for 2005 .

4. BOP Department commenced developing approaches on applying the accrual basis when estimating income on banking sector's securities.

5. Corresponding changes were made to the Government's statistical reporting form 2Invest "Information on investments into the Republic of Belarus from abroad and investments from the Republic of Belarus to abroad" which will allow to collect data on unguaranteed debts of other sectors based on the accrual basis beginning from the 2005 data.

6. The methods of differentiating preliminary, revised and final BOP data in the disseminated tables were developed. These methods were introduced beginning from the publication of the BOP for January-June 2004.

7. To secure timeliness of the BOP data for compiling national accounts, the schedule of the BOP compilation was changed. At present, the BOP data are submitted to the Ministry of Statistics on the no later then $80^{\text {th }}$ day after the end of the reporting period.

\section{B. Ministry of Statistics and Analysis}

Information on Progress in Addressing Concerns Raised by the International Monetary Fund Mission

\begin{tabular}{|c|c|}
\hline Completed & Still to be done \\
\hline \multicolumn{2}{|c|}{ System of National Accounts } \\
\hline $\begin{array}{l}\text { 1. Quarterly national accounts are posted on } \\
\text { the 90th day after the reference period, } \\
\text { starting with data for the first quarter of } \\
2004 \text { (Minstat website). } \\
\text { 2. As of May } 2004 \text { the Quarterly Estimates } \\
\text { of Gross Domestic Product publication } \\
\text { contains more detailed information on } \\
\text { methods for estimating GDP and on their } \\
\text { sources. Data on net exports at constant } \\
\text { prices and statistical discrepancy are } \\
\text { published separately. A brief analysis of } \\
\text { the data is provided. } \\
\text { Information on national accounts is } \\
\text { released simultaneously to all users: } \\
\text { - monthly GDP data are released on the } \\
15^{\text {th }}-17^{\text {th }} \text { of the month following the } \\
\text { reference month (Socio-Economic }\end{array}$ & $\begin{array}{l}\text { 1. Partial replacement of tabular material } \\
\text { with diagrams and charts, starting with } \\
\text { the National Accounts of the Republic } \\
\text { of Belarus publication. To be completed } \\
\text { in March } 2005 \text {. }\end{array}$ \\
\hline
\end{tabular}




\begin{tabular}{|c|c|}
\hline Completed & Still to be done \\
\hline $\begin{array}{l}\text { Situation of the Republic of Belarus } \\
\text { report, Minstat website); } \\
\text { - } \quad \text { quarterly data are released on the 90th } \\
\text { day after the reference period (Minstat } \\
\text { website). } \\
\text { 4. Detailed metadata on the system of } \\
\text { national accounts have been posted on the } \\
\text { Minstat website since January } 2003 \text {. } \\
\text { 5. Notification of a broad range of users of } \\
\text { changes in the methodology for } \\
\text { estimating GDP and revision of GDP data } \\
\text { compared to previously published data, as } \\
\text { they occur (December 30, 2004, Minstat } \\
\text { website). }\end{array}$ & \\
\hline \multicolumn{2}{|c|}{$\begin{array}{r}\text { Price Statistics } \\
\end{array}$} \\
\hline $\begin{array}{l}\text { 1. Time series of consumer and producer } \\
\text { price indices were posted on the Minstat } \\
\text { website while the IMF mission was in the } \\
\text { country. Data are updated monthly on the } \\
12^{\text {th }} \text { of the month following the reference } \\
\text { period. } \\
\text { The question of including used durable } \\
\text { goods (for example, automobiles) in the } \\
\text { consumer price index is currently being } \\
\text { studied. } \\
\text { 3. Computer programs have been developed } \\
\text { to support control audits for verification } \\
\text { of data and identification of errors. }\end{array}$ & \\
\hline \multicolumn{2}{|c|}{ Statistical Planning and Organization of Statistical Observations } \\
\hline \multicolumn{2}{|c|}{ Industrial Statistics } \\
\hline $\begin{array}{l}\text { 1. Monthly indices of the physical volume } \\
\text { of industrial output with a fixed base } \\
(2000=100 \%) \text { are posted on the Minstat } \\
\text { website, with an explanation of the } \\
\text { difference between indices based on a } \\
\text { previous period and those on a fixed base } \\
\text { period. }\end{array}$ & \\
\hline
\end{tabular}




\section{Ministry of Finance}

The Republic of Belarus' Ministry of Finance reviewed the Report on the Observance of Standards and Codes (ROSC) - Data Module concerning government finance statistics (GFS). In our opinion, this report contains a fairly in-depth analysis of GFS compilation practices and a number of useful recommendations, which we are taking into consideration in our improvement of GFS methodology. Changes that have been made since the departure of the mission, as well as plans by the Ministry of Finance to carry out the recommendations contained in the report are reflected in the following table.

Information on Changes Made after the Departure of the International Monetary Fund Mission and Further Plans to Carry Out the Recommendations in the Report on Observance of Standards and Codes

\begin{tabular}{|c|c|}
\hline Implemented & Still to be done \\
\hline $\begin{array}{l}\text { 1. Starting with the } 2005 \text { Annual Budget } \\
\text { Law, innovation funds previously treated as } \\
\text { extrabudgetary resources are included in the } \\
\text { consolidated budget to expand the coverage } \\
\text { of the budget and record the resources of } \\
\text { these funds as a part of the budget using the } \\
\text { budget classification. }\end{array}$ & $\begin{array}{l}\text { 1. The data on execution of the consolidated } \\
\text { budget will be posted on the website of the } \\
\text { Ministry of Finance of the Republic of } \\
\text { Belarus in May } 2005 \text {. } \\
\text { There are plans for further expansion of the } \\
\text { budget coverage by including extrabudgetary } \\
\text { operations and recording them in accordance } \\
\text { with the budget classification starting in } \\
2006 \text {. }\end{array}$ \\
\hline $\begin{array}{l}\text { 2. Consistent with the GFS Manual } 2001 \\
\text { requirements draft functional and economic } \\
\text { classifications were prepared, as well as the } \\
\text { classification of budget revenue. It is } \\
\text { expected that the IMF will perform an expert } \\
\text { assessment of the draft classification of } \\
\text { budget revenues of the Republic of Belarus. }\end{array}$ & $\begin{array}{l}\text { 2. There are plans to make the migration } \\
\text { (with IMF technical assistance) to the budget } \\
\text { classification complying with the } \\
\text { requirements of the Government Finance } \\
\text { Statistics Manual } 2001 \text {. }\end{array}$ \\
\hline $\begin{array}{l}\text { 3. The number of staff involved in the } \\
\text { compilation of government finance statistics } \\
\text { (GFS) has been doubled. Additional } \\
\text { computer equipment has been installed, and } \\
\text { GFS data are backed up regularly. }\end{array}$ & $\begin{array}{l}\text { 3. The number of staff involved in the } \\
\text { compilation of GFS and classification issues } \\
\text { will be increased starting in January } 2005 \text {. }\end{array}$ \\
\hline $\begin{array}{l}\text { 4. The detailed reconciliation of fiscal and } \\
\text { monetary data pertaining to financing of the } \\
\text { budget deficit for } 2003 \text { was done in July } \\
2004 \text {. The data on reconciliation were } \\
\text { presented to the IMF. }\end{array}$ & $\begin{array}{l}\text { 4. The Ministry of Finance together with the } \\
\text { National Bank of the Republic of Belarus } \\
\text { will perform annual reconciliation of fiscal } \\
\text { and monetary statistics. }\end{array}$ \\
\hline $\begin{array}{l}\text { 5. The decision was made to bring the } \\
\text { methodology for compilation of fiscal }\end{array}$ & $\begin{array}{l}\text { 5. A plan of migration to the GFS Manual } \\
2001 \text { will be formulated by July } 2005 \text {. }\end{array}$ \\
\hline
\end{tabular}




\begin{tabular}{|l|l|}
\hline \multicolumn{1}{|c|}{ Implemented } & \multicolumn{1}{|c|}{ Still to be done } \\
\hline statistics into line with the GFS Manual & $\begin{array}{l}\text { 6. Metadata concerning SDDS indicators will } \\
\text { be posted in Russian and English on the } \\
\text { website of the Ministry of Finance in January } \\
2005 .\end{array}$ \\
$\begin{array}{l}\text { There are plans to post the regulatory-legal } \\
\text { basis for the budget process and budget } \\
\text { classification and the relevant metadata on } \\
\text { the Ministry of Finance's website within the } \\
\text { same timeframe. }\end{array}$ \\
$\begin{array}{l}\text { 7. Government finance statistics will be } \\
\text { posted on the Ministry of Finance's website } \\
\text { starting in July 2005. }\end{array}$ \\
$\begin{array}{l}\text { Software for the compilation of quarterly } \\
\text { reports on government finance statistics of } \\
\text { the Republic of Belarus for inclusion in the } \\
\text { IMF's GFS Yearbook will be upgraded in } \\
\text { 2005. } \\
\text { There are plans to publish GFS data on the } \\
\text { Ministry of Finance's website in accordance } \\
\text { with the GFS Manual 2001 approach starting } \\
\text { in January 2006. }\end{array}$ \\
\hline
\end{tabular}




\section{INTERNATIONAL MONETARY FUND}

REPUBLIC OF BELARUS

\section{Detailed Assessments Using the Data Quality Assessment Framework (DQAF July 2003)}

Prepared by the Statistics Department

Approved by Robert W. Edwards and Michael C. Deppler

January 24,2005

This document contains a detailed assessment by dataset of the elements and indicators that underlie the data quality dimensions discussed in Republic of Belarus's Report on the Observance of Standards and Codes (ROSC) - Data Module. It also includes as appendices the Data Quality Assessment Framework generic framework and the results of the users' survey. 


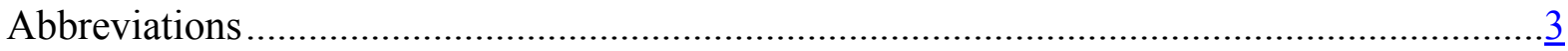

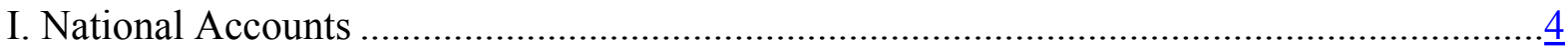

II. Price Statistics (Consumer Price Index) …......................................................... 50

III. Price Statistics (Producer Price Index) .....................................................................

IV. Government Finance Statistics ................................................................. 103

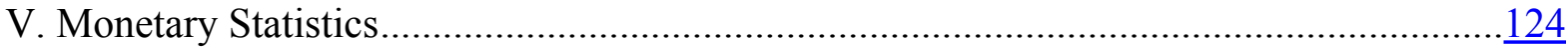

VI. Balance of Payment Statistics........................................................................ 142

Tables

1. Summary of Results for National Accounts ............................................................ 49

2. Summary of Results for Price Statistics (Consumer Price Index) ....................................

3. Summary of Results for Price Statistics (Producer Price Index) ..................................102

4. Summary of Results for Government Finance Statistics ......................................... $\frac{123}{141}$

5. Summary of Results for Monetary Statistics ...........................................................

6. Summary of Results for Balance of Payments Statistics ............................................165

Appendices

I. Summary of the Special Data Dissemination Standard (SDDS) ................................. 166

II. Data Quality Assessment Framework - Generic Framework .................................... $\frac{168}{171}$

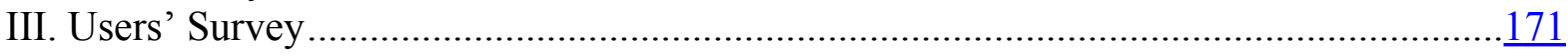

Appendix Tables

Questionnaire for Users of Official Macroeconomic Statistics ..................................... 180 


\section{AbBreviations}

1993 SNA

BPFAFD

BPM5

BSD

CIS

COFOG

COICOP

CPI

DQAF July 2003

DPS

DSBB

GDP

GFS

GFSM 1986

GFSM 2001

Goskomstat

HIES

HFCE

IMF

ISIC

ITRS

MCSD

MFSM

Minstat

$\mathrm{MoF}$

NAD

NBRB

OKED

PPI

ROSC

SDDS

WGBP
System of National Accounts 1993

Budget Policy, Financial Analysis, and Forecasting Division of the MoF

Balance of Payments Statistics Manual, fifth edition

Banking Statistics Department of the NBRB

Commonwealth of Independent States

Classification of the Functions of Government

Classification of Individual Consumption by Purpose

Consumer Price Index

Data Quality Assessment Framework, July 2003 version

Department of Price Statistics (Republic of Belarus)

Dissemination Standards Bulletin Board

Gross Domestic Product

Government Finance Statistics

A Manual of Government Finance Statistics 1986

Government Finance Statistics Manual 2001

Russia's State Statistical Committee

Household Income and Expenditure Survey

Household final consumption expenditure

International Monetary Fund

International Standard Industrial Classification of all Economic Activities

International Transactions Reporting System (Republic of Belarus)

Money and Credit Statistics Division of the NBRB

Monetary and Financial Statistics Manual

Ministry of Statistics and Analysis of the Republic of Belarus

Ministry of Finance (Republic of Belarus)

National Accounts Department (Republic of Belarus)

National Bank of the Republic of Belarus

General Classification of Types of Economic Activity

Producer Price Index

Report on the Observance of Standards and Codes

Special Data Dissemination Standard

Interbank Working Group on Balance of Payments Methodological Issues 


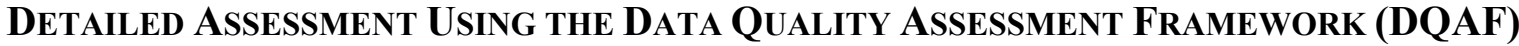

The following detailed information on indicators of statistical practices in the areas of the national accounts, prices, government finance, monetary, and balance of payments statistics was gathered from information provided by the officials and publicly available documents. This information, which is organized along the lines of the generic Data Quality Assessment Framework, July 2003 version (see Appendix II), was used to prepare the summary assessment of data quality elements, based on a four-part scale of observance, shown in the Republic of Belarus's Report on the Observance of Standards and Codes (ROSC)—Data Module. ${ }^{6}$

\section{National Accounts}

\section{Prerequisites of quality}

\subsection{Legal and institutional environment}

\subsubsection{The responsibility for collecting, processing, and disseminating the statistics is clearly specified}

The production of official statistics in the Republic of Belarus is the responsibility of the Ministry of Statistics and Analysis of the Republic of Belarus (Minstat). The Minstat operates under the Law of the Republic of Belarus on State Statistics (the Law on State Statistics), which was adopted by the House of Representatives on January 11, 1997, approved by the Council of the Republic on January 30, 1997, and signed by the President of the Republic of Belarus on February 17, 1997. The Law on State Statistics was developed in line with recommendations of Eurostat.

The Minstat is accountable to the Council of Ministers of the Republic of Belarus and operates under Belarusian legislation. It has its own settlement account and other accounts with banking institutions.

The State statistical system for the Republic of Belarus comprises the Minstat, and oblast (including City of Minsk), district and city agencies of statistics. The Minstat and its agencies

\footnotetext{
${ }^{6}$ This report is based on information provided by the Belarusian authorities prior to and during a staff mission during March 23-April 7, 2004 and publicly available information. The mission team was headed by Mr. Gérard G. Raymond and comprised Messrs. Roman Skarzynski and Samuele Rosa, Mmes. Rita Mesias and Shelley Winston (all Statistics Department), Mr. David Allen (Expert), and Ms. Claudia Fagbemi (Assistant).
} 
in oblasts, cities and regions, and other organizations subordinated ${ }^{7}$ to the Minstat constitute a single system of State statistics for the Republic of Belarus.

The Minstat is headed by a Minister who is appointed under the Constitution by the President. The Minister is a member of the government and is empowered to issue directives and instructions that are binding on subordinate statistical bodies within the Minstat.

The Minstat has a Board of Management that comprises the minister (as chairman), his deputies, and other staff. The Board of Management considers and determines fundamental issues relating to the organization of statistical activities (for example, methodology, questionnaires, release practices, staff appointments and terminations, performance at regional levels, organization structure, statistical program priorities, and budgetary allocations). The Minister of Minstat, as a member of the Cabinet of Ministers, reports to the government concerning major decisions made by the Board.

There is also an Inter-Agency Council for State Statistics, established under a government resolution, which makes proposals on methods and questionnaires, and considers proposals for the inclusion in the statistical work plan (discussed below). The Inter-Agency Council for State Statistics reviews proposals submitted to it, and makes recommendations that are forwarded to the Council of Ministers for decisions about financing.

The Inter-Agency Council for State Statistics comprises the Deputy Prime Minister of the Republic of Belarus (Chairman), the Minister of the Minstat, the Minister of Labor and Social Protection, the Minister of Justice, the Deputy Ministers of Industry, Finance, and Economy, and representatives of the Academy of Science and other bodies. The composition of the Council allows it to take direct account of user requirements to some extent, but it is not very broadly based in terms of membership compared with models in some countries. Due to its membership, it functions as an advisory body rather than an executive decision making body. The reports of the Council are publicly available documents.

Article 3 of the Law on State Statistics specifies the basic tasks of state statistics as:

- $\quad$ collecting, processing, compiling and analyzing economic and social statistics, using scientifically based statistical methodology; and

- disseminating statistical information to governmental authorities and other users.

\footnotetext{
${ }^{7}$ Subordinate organizations include main computing center, Statistical Research Institute Computing Centers of Oblast (City of Minsk) department of statistics.
} 
The Minstat, its offices in the oblasts, cities, and rayons, and the other subordinate organizations constitute the uniform system of state statistical authorities of the Republic of Belarus. The Minstat is subordinate to the Council of Ministers of the Republic of Belarus. The Minstat acts on the basis of the provisions of the Minister of the Minstat, as approved by the Council of Ministers of the Republic of Belarus, and other regulatory acts.

Article 10 provides that State statistical authorities have the right to:

- receive statistical data, in the manner established by the central statistical authority, from legal entities, and entrepreneurs who have not formed a legal entity;

- $\quad$ verify the reliability of statistical data and, where distortions are found, to give mandatory instructions concerning their elimination and appropriate corrections in aggregated statistical data; and

- $\quad$ require entities to comply with the requirements of the Law, including entities that are not legally incorporated.

Under Article 11, ministries and other central administrative authorities that produce state statistics shall have the right to:

- $\quad$ receive and use statistical data "in the manner specified by Articles 5, 8, and 9 of this Law"; and

- monitor the status of primary accounting and statistical reporting, and check the authenticity of statistical data reported.

Under Article 12, State statistical authorities are required to:

- $\quad$ organize state statistical observations and provide government authorities with reliable and objective statistical information on the socio-economic situation of the country;

- $\quad$ ensure the accessibility of summary statistical information for a wide range of users, and give necessary explanations and comments on the methodology of producing statistical data, including through the mass media; and

- $\quad$ ensure that the primary data collected by state statistical authorities are not subject to disclosure and are used exclusively for statistical purposes.

The Minstat is required to provide State bodies and other users with reliable and objective economic and social statistics, including national accounts statistics. It also provides explanations about methodologies for compiling data. 
Section 34 of the Constitution of the Republic of Belarus provides that citizens have the right to receive information on the activities of State bodies, and those bodies shall provide citizens with an opportunity to obtain access to the materials pertaining to their rights and legitimate interests. This Section of the Constitution is endorsed by Article 12 of the Law on State Statistics. The extensive publication program of the Minstat is consistent with this provision in the Constitution.

Within the Minstat, the National Accounts Department (NAD) is responsible for the compilation of the national accounts for the Republic of Belarus.

\subsubsection{Data sharing and coordination among data-producing agencies are adequate}

The Law on State Statistics provides for data sharing and coordination of statistical activities.

- $\quad$ Article 5 provides that ministries and other central administrative authorities shall compile state statistics in accordance with the forms and methodological instructions approved by the central statistical authority.

- $\quad$ Article 7 provides that State statistical observations (including state administrative data, one-time assessments, censuses, and sample surveys) shall be carried out by state statistical authorities, ministries, and other central administrative authorities on the basis of the methodological instructions, programs, and forms of statistical reporting approved by the central statistical authority.

- $\quad$ Article 10 states that decisions of the state statistical authorities, within their competence, shall be mandatory for implementation by ministries, other central administrative authorities, local executive and administrative authorities, legal entities and other individual entrepreneurs.

- Article 13 requires ministries and other central administrative authorities that compile state statistics to:

○ ensure the collection, processing, and reliability of statistical data in their areas of responsibility; and

○ supply to state statistical authorities, on their demand, statistical data specified by state statistical reporting.

The Department of Statistical Planning and Statistical Monitoring within the Minstat is responsible for ensuring effective coordination between the Minstat and the ministries with the primary responsibility for compiling the statistics and other data producing agencies. 


\subsubsection{Individual reporters' data are to be kept confidential and used for statistical purposes only}

Article 9 provides that information containing state and commercial secrets shall not be subject to disclosure, and stipulates that statistical information shall be used for State and scientific purposes and for informing the public. This provides for the protection of the privacy of individual data submitted by, and in respect of, persons.

Article 15 specifies that employees of State statistical authorities, ministries, and other central administrative authorities who produce state statistics must not violate the requirements of the Law concerning the collection and use of statistical data and for concealing and distorting them. Employees of the Minstat are required to sign a contract at the commencement of employment that they will not divulge State secrets. This requirement is reinforced in a Duty Manual supplied to each staff member. All computers are password protected. The Minstat's officials informed the mission that there has been no instance where an employee has violated this requirement of the Law.

Article 12 further reinforces the requirement for confidentiality of individual data supplied. State statistical authorities are required to preserve state and commercial secrecy, and to ensure that primary data obtained from legal entities or physical persons are used exclusively for statistical purposes. Similarly, Article 13 requires that ministries and other central administrative authorities that produce state statistics shall preserve state and commercial secrecy. In addition, article 21 of the Law on Civil Service in the Republic of Belarus (law No. 204-3 of June 14, 2003) states, among the obligations of civil service that civil servants must not disseminate state secrets entrusted to them, and the disclosure of state secrets could result in their dismissal of the civil service.

The mission discussed with senior officials from the Minstat the question of release of data where only a small number of entities are involved. The mission was informed that, where one or two nongovernment enterprises contribute to a statistical cell, the Minstat ensures that such data remains confidential, but that these rules are not applied where government enterprises are concerned. The mission considers that more comprehensive procedures are required to guide staff in ensuring that statistics released do not disclose information relating to an individual entity, either directly or by deduction. This is important in order to maintain public confidence in the Minstat.

The Minstat's officials indicated that there are situations where an entity may give written consent for the disclosure of information about the entity, but that the Minstat seeks to avoid too many such situations from a workload point of view. The mission observed, however, that it is not clear from the legislation that the Minstat has the authority to release individual data with the consent of the entity concerned. This is a legal right of statistical agencies in some other countries and the mission considers that the legislation in the Republic of Belarus should be clarified concerning this right, even though it is seldom exercised. 
The Minstat should consider seeking an amendment to the Law on State Statistics enabling the Minstat to release data that would otherwise be confidential with the consent of the entity (entities) involved. This provision would need to be used very sparingly, but would allow publication of significant data where only one or two entities are involved; for example, the production of a specific commodity by one or two producers.

All survey questionnaires state clearly, on the top of the front page, that all information collected by the Minstat will be kept confidential and used for statistical purposes only. Officials of the Minstat assured the mission that there is adequate physical security for all premises, adequate physical protection of computing facilities, and various encoding procedures, all of which serve to assist in protecting the confidentiality of the data stored in the premises of the Minstat and guard against unlawful access to data.

\subsubsection{Statistical reporting is ensured through legal mandate and/or measures to encourage response}

There is a clear legal mandate for collection of information for statistical purposes. Article 8 requires that all legal entities, and entrepreneurs who have not formed legal entities, shall submit statistical reports free of charge, observing the forms, deadlines, and addresses approved by the central statistical authority. Article 8 also provides that questionnaires and deadlines for statistical reporting by banks, free of charge, shall be approved by the central statistical authority as agreed with the National Bank of the Republic of Belarus (NBRB).

Under Article 14, officials and entrepreneurs carrying out their activity without forming a legal entity who evade the mandatory submission of statistical data to state statistical authorities and also to ministries and other central administrative authorities that produce state statistics, or submit them in a distorted form or in violation of the established schedules, are in breach of the legislation. In addition, damage caused as the result of the submission of distorted statistical data shall be subject to penalty under legislation of the Republic of Belarus.

The Minstat's employees are entitled to visit business entities in order to check the accuracy of the data reported in State statistical questionnaires. Such inspections are selectively undertaken by the Minstat, sometimes involving specialists of branch ministries. These measures result in a high level of cooperation and the collection of reliable data. In 2003, inspections on data accuracy were carried out at 3,700 business entities. Amendments were incorporated where discrepancies were discovered.

In the event that an entity refuses to provide information required under the Law on State Statistics, the Minstat may require the entity to appear before a court and the court may impose a penalty. Court action is, however, used as a last resort and exercised in relatively few instances. Such cases have received publicity that is favorable to the Minstat and this appears likely to have had a deterrent effect on others who may contemplate refusal to comply with the Law on State Statistics. 
The Minstat, therefore, has very strong powers to collect information for statistical purposes and this is reflected in very high response rates and, presumably, in accurate responses in the various questionnaires. The Minstat does not appear to have used other approaches to encourage response, such as the provision of brochures explaining the uses and importance of specific fields of statistics and the supply of summary data, free of charge, to respondents.

The Minstat may wish to consider supplementary approaches of these kinds as means of maintaining high levels of response.

\section{$0.2 \quad$ Resources}

\subsubsection{Staff, facilities, computing resources, and financing are commensurate with statistical programs}

The Minstat has about 2,200 staff of which about 360 are located in headquarters in Minsk. About 90 percent of the staff is female. The overall staffing levels for the Minstat are regarded by senior management as adequate and the staff turnover appears to be relatively stable. However, there are difficulties in hiring highly qualified programmers because of their high demand and better remuneration in other organizations.

Retirement age is normally 55 years, but some retirees are re-appointed as temporary employees, in some cases, temporarily replacing a staff member who is absent on maternity leave. The Minstat pays particular attention to ensuring that there are sufficient staff numbers to effectively carry out its various operations, while allowing for annual leave, maternity leave, and other staff entitlements.

The NAD has 31 staff and the head of the NAD regards this as an adequate number for the tasks involved at present. However, any significant increase in responsibilities such as adding to the range of national accounts statistics produced, would warrant an examination of the adequacy of staff numbers. In addition, the reliability of the national accounts statistics could be enhanced by the allocation of specific resources in the NAD (for example, one person dedicated to estimation of the nonobserved economy) (see section 3.3.1).

Staffing has been relatively stable over recent years; for instance, only four new staff joined the NAD during the last five years. New staff typically join as graduates of the Belarusian State Economic University. There are not many cases of national accounts staff leaving to work in other organizations. However, there have been few cases of NAD staff on maternity leave in recent years.

The age profile of the NAD shows that about 50 percent of the staff are aged over 45 years (retirement is usually at age 55) and the other 50 percent are mainly aged between 25 and 35 . The average age of NAD staff is 42.5 years. The challenge for the NAD is to continue to nurture and develop the "younger group" from which will ultimately form the leadership group. The NAD ensures that each specific section of the department comprises people from 
both the "older" and "younger" groups to provide succession. There are some measures in place to encourage the retention of experienced staff. However, there are constraints on promotion and merit increases within the civil service system.

The Minstat is at present in the process of providing additional computing capacity throughout the organization. This will include the replacement of a number of old computers with new ones with much enhanced capabilities. The NAD, at present, has 17 personal computers, many of which are now old and of limited capacity and speed. The NAD is likely to receive an allocation of new computers in April 2004 and the mission strongly supports this as a means of improving efficiency in data handling.

Data back-up arrangements for national accounts data are limited. Certain data are backed up on diskette (as most NAD computers do not have a compact disk facility) and aggregated data are stored on hard copy. The mission considers that greater attention should be given to backing up data on a regular basis, including off-site storage, to guard against the possibility of system breakdowns and loss of hardware and software.

\subsubsection{Measures to ensure efficient use of resources are implemented}

Resources within the Minstat are allocated in accordance with the statistical work plan that is developed each year. The Minstat arranges for statistical inquiries to be conducted in accordance with the statistical work plan for the Minstat. The statistical work plan is prepared in consultation with ministries and other administrative bodies. This instrument is used by the Minstat for coordinating and approving statistical plans.

The statistical work plan is developed in an iterative way, starting with submissions from the heads of each department. The Department of Planning and Statistical Monitoring in the Minstat then drafts the entire work plan for consideration and approval by the Board of Management. The statistical work plan is approved in August of each year and covers the following five years. It includes details of plans to be achieved in each department of the Minstat, and target dates for various stages of development. Each department presents information on progress and achievements at annual meetings of the Board of Management.

Article 6 provides that the State statistical authorities are financed from state budget funds in accordance with the statistical work plan that is approved by the Council of Ministers of the Republic of Belarus. Additional statistical work may be carried out through supplementary financing from the state budget or funds provided by those requesting this work. The work plan sets out all statistical activities to be undertaken by the Minstat during the course of the plan, including target dates for completion of specific tasks. It is the responsibility of each department's head to ensure that their components of the work plan are completed satisfactorily. The statistical work plan is reviewed annually by the Board of Management of the Minstat. There is a certain amount of flexibility to incorporate any important new statistical activity between annual reviews where a major new statistical requirement has been articulated by the government. 
Under Article 12 of the Law on State Statistics, State statistical authorities are required to "use international concepts, classifications, and methods in compiling statistics as the basis for ensuring the harmony and effectiveness of the statistical system of the Republic of Belarus on all official levels.”

National accounts and other relevant statistics departments within the Minstat generally use consistent methodologies and classification systems, thereby avoiding the need for significant adjustments to the data and leading to efficiencies in data handling. The survey questionnaires are reviewed annually by the Department of Planning and Statistical Monitoring, and adjustments are made where required.

The survey fieldwork is conducted under the control of the regional statistical bodies and the source data are collected, reviewed, and collated at that level. The collated data are submitted to headquarters in electronic format. This minimizes costs of administering surveys and compiling statistical aggregates.

A range of external training opportunities has been provided in recent years for national accounts staff, including:

- technical assistance from the Organization for Economic Co-operation and Development (OECD) in the formative years of developing the national accounts according to System of National Accounts 1993 (1993 SNA);

- $\quad$ one multi-sector advisor and one national accounts advisor from the International Monetary Fund (IMF) spanning a number of years;

- $\quad$ training at the Joint Vienna Institute for about seven staff at different times; and

- $\quad$ training for about ten staff provided by the German Federal Statistics Bureau.

In addition, NAD staff meet once a month to consider and discuss specific national accounts issues and to learn more about new developments and improved methodologies. Over recent years, some NAD staff have benefited from participation in workshops organized by Eurostat. Staff also participate in meetings on statistics for the Commonwealth of Independent States (CIS). These meetings discuss methodological issues and ways of improving efficiency.

An evaluation of the performance of each staff member of the Minstat is conducted annually and continued employment (renewal of contract) and promotion is determined on the basis of the evaluation.

Improved computing facilities should enhance productivity in the NAD, and access by the NAD to the internal electronic communication system for the Minstat should provide further opportunities for improved productivity and data sharing. 
The mission noted a large number of questionnaires in use throughout the Minstat and much evidence of duplication in data requirement, as well as cases where similar data are requested in different survey vehicles. For instance, 37 different questionnaires are used in the collection of agricultural statistics. The mission sees considerable scope for the rationalization of questionnaires and surveys to eliminate duplication while still satisfying the data needs for national accounts compilation and users in government and other organizations.

The mission considers that the Minstat should embark on a program of survey and questionnaire rationalization in order to improve internal efficiencies within the Minstat, reduce reporting load on respondents, and release resources for other priority statistical work, while satisfying the major needs for compiling national accounts. This task needs to be done carefully over a period of years.

\subsection{Relevance}

\subsubsection{The relevance and practical utility of existing statistics in meeting users' needs are monitored}

Apart from the Inter-Agency Council for State Statistics, which focuses on methodological issues, there is no committee to provide advice about new and emerging data needs. The mission considers that the Minstat should examine the desirability of establishing a more broadly based user committee to provide it with advice on statistical policy, methodology, and priority issues.

The relevance and practical utility of the national accounts data in meeting user needs are not assessed in any systematic way. The Minstat has not conducted any user surveys in the field of national accounts statistics and does not have any mechanism in place to systematically monitor user feedback on these statistics. National accounts statistics have not yet been on the agenda for consideration by the Inter-Agency Council for State Statistics. However, the NAD does have close contact with a small number of users, often in the context of providing data or explaining methodology, and considers that it is well informed about user requirements and views on national accounts issues. The NAD does not have any plans for such a group relating to national accounts.

The Minstat should consider the potential benefits accruing from a user advisory group, representative of a range of users of national accounts statistics in government, academic organizations, trade unions, and the private sector, to meet regularly (about four times a year, after the initial more frequent meetings) to provide advice on the range of data produced, methodological issues, perceptions of quality, and possible future developments. It is worth noting that an additional potential benefit from such a user group is an improved user understanding of national accounts data and the possibility of external support in the face of criticism about the statistics produced. The Minstat should also consider conducting occasional surveys of users of national accounts statistics to obtain feedback. 


\section{$0.4 \quad$ Other quality management}

\subsubsection{Processes are in place to focus on quality}

The Department of Planning and Statistical Monitoring within the Minstat has prime responsibility for placing a strong focus on the quality of statistical processes and products. It coordinates all work associated with the improvement and maintenance of statistical quality.

Staff of the Minstat participate in international discussions where statistical techniques and practices are discussed and this serves to further emphasize the importance of striving for high quality data. Some studies are undertaken jointly with Russia's State Statistical Committee (Goskomstat) and comparisons of methods are conducted to share views and information about new statistical developments.

\subsubsection{Processes are in place to monitor the quality of the statistical program}

The Minstat's Department of Statistical Planning coordinates all work associated with the improvement and maintenance of statistical quality. The information on such issues is considered by the Board of Management. All statistical questionnaires are sent to the Department of Statistical Planning for review. Then, the questionnaires are considered by the Scientific-Methodological Council of the Minstat and approved by the Minstat's Board of Management.

The functions of the Board of Management of the Minstat include providing a clear focus on quality through close attention to methodological issues. This is, in turn, conveyed by management to staff throughout the organization. Each staff member is given a copy of a Duty Manual that, inter alia, reinforces the importance of high standards of work and the need to produce high standard statistics. In addition, staff members, as civil servants, are made aware of their responsibilities under the Law on the Civil Service, which includes references to the requirement for work of a high standard.

According to Article 3 of the Law on State Statistics, "Basic Tasks and Principles of State Statistics that is publicly available," states that the basic principles of state statistics are: (a) objectivity and reliability of statistical information; (b) stability and comparability of statistical data; and (c) accessibility and openness of statistical information within the bounds set by the legislation of the Republic of Belarus.

The NAD addresses the quality of national accounts data through extensive checks on the validity of data supplied from the wide range of sources accessed. Data are analyzed for internal consistency and for comparability over time and also, wherever possible, they are checked for consistency with other data sources. In addition, broad national accounting and other aggregates are reconciled. In the course of this work, national accounts staff raise questions where necessary with the source organizations and provide feedback on the accuracy and reliability of the data and the need for possible adjustments. 


\subsubsection{Processes are in place to deal with quality considerations in planning the statistical program}

In developing the overall statistical plan, quality issues are addressed, both at individual department level and for the Minstat as a whole. Trade-off decisions are made, for example between timeliness and accuracy, and between accuracy and resources. Such decisions are made at all levels of the organization.

Within the NAD, trade-off decisions of these kinds are typically made at the stage where the use of an alternative data source or methodology is contemplated. Another example would relate to further development of national accounts, where decisions about priorities are required in the context of scarce resources.

\section{Assurances of integrity}

\subsection{Professionalism}

\subsubsection{Statistics are produced on an impartial basis}

Article 4 of the Law on State Statistics provides that the central statistical authority is subordinate to the Council of Ministers and shall act on the basis of the regulations approved by the Council of the Republic of Belarus. The regulations are prepared by the Minstat.

Article 10 provides that interference by any government authorities, officials, and other persons in the activity of the state statistical authorities shall not be permitted, and the mission was informed that there has never been any question of interference or attempted interference with the professional independence of the Minstat.

The appointment and termination of the minister are determined by the government. Upon election of the president a new government is formed. The present Minister of Statistics was appointed in 1998. The Minstat is contemplating proposing a change from a ministry to a National Statistical Committee, to help reinforce the notion of the independence of the chief statistician, making decisions based purely on statistical considerations and free from political interference.

Recruitment and promotion of specialists in the Minstat are based on the specialists' expertise in statistics. Specialists are usually recruited from the faculty of the department of statistics at the Belarusian State Economic University. The Minstat encourages research and analysis by specialists to maintain the Minstat's reputation for professionalism.

Professionalism is also promoted through the encouragement of staff participation in training courses, workshops and seminars, to ensure awareness and understanding of statistical standards and good statistical practices. 


\subsubsection{Choices of sources and statistical techniques as well as decisions about dissemination are informed solely by statistical considerations}

The sources and methods for compiling price statistics and component statistics are fully under the control of the Minstat, and concepts and standards follow international standards to a large extent. Appropriate data sources are used throughout the compilation of the national accounts. There appears not to have been any outside interference or attempted interference in matters of sources, methods, and dissemination.

Interference by any government authorities, officials, and other persons in the activity of the state statistical authorities is not permitted. There have been no known cases of interference or attempted interference.

Article 10 of the Law of the Republic of Belarus on State Statistics provides guarantees of independence in the selection of the methodology, data sources, content, and format of the data disseminated by the Minstat. According to the Minstat, there is no external interference in the conduct of its work. Article 3 of the Law on State Statistics reinforces this by stating that one of the basic principles of state statistics is objectivity and reliability of statistical information.

\subsubsection{The appropriate statistical entity is entitled to comment on erroneous interpretation and misuse of statistics}

Article 10 of the Law on State Statistics gives State statistical authorities the right to comment on the incorrect utilization and interpretation of statistics. The NAD informed the mission that on occasions it has received, and responded to, criticism about the national accounts data, and that the criticisms tend to be in terms of comments about the size of the movement in gross domestic product (GDP). In the opinion of the critics, the GDP movements are sometimes considered to be under- or over-stated.

The NAD provides some explanations about the compilation of the national accounts in its national accounts publications and these should assist in reducing the amount of public criticism. However, the explanations tend to refer mainly to the concepts used, with little if any information about data sources and methods. Much more detail is provided in the Methodological Guidelines in Statistics (2003), but this publication has very limited circulation (only 100 copies were printed) and it is not referred to in the Catalogue of Publications. The mission was informed that the Minstat plans to publish the Methodological Guidelines on its web site.

It would also be useful if the NAD could provide some analytical comments in its publications, identifying the main factors underlying unusual figures and movements, in order to improve user understanding of the data and reduce the likelihood of misinterpretation. 
The Minstat has not regularly held any media conferences at the time of release of national accounts or other publications. However, requests are sometimes received for an article or a presentation on television, on a national accounts topic, and such requests are usually accepted.

\subsection{Transparency}

\subsubsection{The terms and conditions under which statistics are collected, processed, and disseminated are available to the public}

The Law on State Statistics was published in the Republic Newspaper at the time that it was signed by the President in February 1997. The Law is published on the Minstat's web site in both Russian and English. Any user can request the Law from the database of legal and regulatory information, which is maintained by the National Center of Legal Information. The general public may also refer to the Law on State Statistics at the Minstat headquarters, and in the Minstat's oblast, city, and district offices. Each of the Minstat survey questionnaires refers to a specific resolution made by the Minister of the Minstat that authorizes that survey.

As noted above, the national accounts publications show information about concepts and the Methodological Guidelines in Statistics provide considerably more detail about national accounts (and also cover all major data products of the Minstat).

The Minstat produces annual reports on its performance, which are considered at expanded meetings of the Board of Management, where there are invited representatives of oblast (including City of Minsk) statistical agencies and Council of Ministers of the Republic of Belarus.

The Minstat may wish to consider increasing public awareness about its activities and products (for example, through brochures and the provision of summary data free of charge) as a means of improving public confidence in the Minstat and maintaining a high level of cooperation in its surveys.

\subsubsection{Internal governmental access to statistics prior to their release is publicly identified}

The Minstat's web site states that there is no internal governmental access to national accounts statistics prior to their release to the public. There is, however, an exception for annual national accounts data. The Ministry of the Economy, the NBRB, and other major users receive summary data in December, well in advance of the detailed publication, which is issued in the following March. Information on access to annual and summary national accounts data should also be published on the Minstat's web site. 


\subsubsection{Products of statistical agencies/units are clearly identified as such}

All national accounts data products are clearly identified as being issued by the Minstat on the web site and in publications. In the case of joint publications, the part attributable to the Minstat is clearly identified. The Minstat requests acknowledgement when its statistics are published by others, and this occurs in practice with national accounts statistics.

\subsubsection{Advanced notice is given of major changes in methodology, source data, and statistical techniques}

Major changes in methodology are noted in the relevant publications after their implementation, but not in advance of publication. However, major users are often notified in advance of methodology changes in the course of normal working contacts.

The possibility of major changes is foreshadowed in the statistical work plan, but this is received by a very restricted group of persons and organizations. The mission believes that the Minstat should consider publicly announcing significant changes to the basis for compiling national accounts in advance, including through press briefings. While it might be argued that some users are not particularly interested in knowing about upcoming changes, it is also fair to say that advance notice of this kind can be useful in improving user knowledge and reducing criticisms based on misunderstandings about the data and the underlying methodology. The mission was informed that, prior to 2003, advance notice of planned changes, in summary form, was given to the public in the National Register of Legal Acts. However, this practice has now been discontinued.

\subsection{Ethical standards}

\subsubsection{Guidelines for staff behavior are in place and are well known to the staff}

Articles 13 and 15 of the Law of the Republic of Belarus on State Statistics provide guidelines on correct behavior when the Minstat or its staff is confronted with potential conflict of interest situations.

Article 13, "Obligations of Ministries and Other Central Administrative," stipulates that authorities that maintain state statistics are required to preserve state and commercial secrecy.

Article 15, "Liability for Violations Committed while Using Statistical Data," states that employees of state statistical authorities, ministries, and other central administrative authorities who maintain state statistics shall bear liability in accordance with the legislation of the Republic of Belarus for violating the requirements of this Law concerning the collection and use of statistical data and for concealing and distorting them.

Requirements regarding staff behavior are notified in the Duty Manual, which is provided to each staff member. The Law on civil service also provides guidelines about staff behavior. 
This Law was recently amended and training courses were arranged to inform staff about their responsibilities.

All new staff are required to sign an employment contract that outlines the ethical standards, and are reminded annually of these standards.

The Law on Civil Service requires civil servants to observe culture of communication and other norms of business ethics, not allow actions that negatively affect civil service, maintain confidentiality about work activities, and observe internal regulations of work procedures, especially with those related to confidential information. It provides guidelines about staff behavior, including the need to ensure the preservation of the confidentiality of data for individual entities. This Law was recently amended and training courses were arranged to inform staff about their responsibilities.

\section{Methodological soundness}

\subsection{Concepts and definitions}

\subsubsection{The overall structure in terms of concepts and definitions follows internationally} accepted standards, guidelines, or good practices

National accounts compilation is based on the 1993 SNA and the methodology for compiling the national accounts is described in detail in the publication Methodological Guidelines on Statistics (2003) and, in more summary form, in national accounts publications.

The requirement to adopt international standards in reinforced by Article 10 that requires the Minstat to cooperate in the field of statistics with the statistical authorities of other countries and international organizations; and by Article 12 that provides that the Minstat should develop and improve methods of statistical observations and indicators in accordance with international statistical standards.

\subsection{Scope}

2.2.1 The scope is broadly consistent with internationally accepted standards, guidelines, or good practices

The system of national accounts for the Republic of Belarus includes the following accounts and tables that are considered part of the minimum requirements for the implementation of the 1993 SNA by the Inter-Secretariat Working Group on National Accounts:

- $\quad$ value added and GDP by economic activity at current and constant prices;

- $\quad$ expenditure components of GDP at current and constant prices; 
- $\quad$ generation of income account;

- $\quad$ allocation of primary income account;

- $\quad$ secondary distribution of income account;

- $\quad$ redistribution of income account;

- $\quad$ disposable income account;

- $\quad$ adjusted disposable income account;

- $\quad$ capital account; and

- $\quad$ rest of the world account.

The accounts (apart from expenditure of GDP and the rest of the world account) are classified by institutional sector.

The NAD does not compile the financial account. It has compiled some experimental estimates, but expects it will be some years before the financial account is fully developed.

The following additional accounts and tables that the Inter-Secretariat Working Group on National Accounts has determined as recommended for implementing the 1993 SNA are compiled on a regular basis:

- $\quad$ quarterly value added and GDP at current and constant prices by economic activity;

- $\quad$ quarterly expenditures of GDP at current and constant prices; and

- $\quad$ annual input-output tables.

Other accounts regularly compiled and published by the Minstat include quarterly GDP by income components at current prices.

The concept of residence used in the national accounts is consistent with the 1993 SNA and the Balance of Payments Manual, fifth edition. In particular, the following are included as part of the Belarusian economy for national accounts compilation:

- $\quad$ territorial enclaves in the rest of the world (such as embassies);

- $\quad$ free zones/bonded warehouses/factories operated by offshore enterprises under customs control; and 
- $\quad$ workers who work part of the year in another country.

The production boundary is broadly in accordance with the 1993 SNA. The following items are in the scope of measurement of output:

- $\quad$ own-account production of all goods for own final consumption;

- $\quad$ research and development on own-account;

- $\quad$ output of goods for own-account fixed capital formation;

- $\quad$ mineral exploration;

- $\quad$ production of entertainment, literary, and artistic originals; and

- $\quad$ production of computer software.

Annual estimates of exhaustiveness are made for the various sectors of the economy, based on a variety of data sources and special surveys. Ratios are calculated from the annual data and incorporated in estimates for quarterly GDP data, to take account of under-coverage and under-reporting of legal activities. A systematic approach to these calculations is made, but resources have not allowed the conduct of special surveys to supplement the existing data and to improve the reliability of the estimates. The mission considers it is now important that the Minstat undertakes some small-scale supplementary surveys' design to improve the estimates of exhaustiveness.

Illegal production is not in the scope of output measurement with the exception of illegal (home-based) production of vodka for which estimates are made. However, the NAD considers that the methodology for estimating the nonobserved economy may result in some inclusion of illegal production.

The assets boundary broadly conforms to the 1993 SNA and includes the following items:

\section{Tangible assets}

- $\quad$ defense related assets that can be used for civilian purposes;

- $\quad$ valuables owned by households; and

- $\quad$ agricultural work-in-progress. 


\section{Intangible assets}

- $\quad$ mineral exploration;

- $\quad$ systems and standard applications computer software;

- $\quad$ entertainment, literary, or artistic materials; and

- $\quad$ patented entities.

Historical monuments, purchased goodwill and valuables other than those owned by households are not included in the assets boundary.

\subsection{Classification/sectorization}

\subsubsection{Classification/sectorization systems used are broadly consistent with internationally} accepted standards, guidelines, or good practices

Article 10 of the Law on State Statistics provides that State statistical authorities shall have the right to cooperate in the field of statistics with the statistical authorities of other countries and international organizations.

The classification of transactions, flows, and institutional units broadly follow the recommendations of the 1993 SNA.

The Classification of Branches of the Economy (OKONX) is currently used to classify economic activity. This differs markedly from the International Standard Industrial Classification (ISIC), and users would find it difficult to make comparisons with data based on ISIC for many economic activities.

The Minstat has commenced implementing a new activity classification system, known as the General Classification of Types of Economic Activity (OKED). This is closely related to the ISIC and is fully compatible at the four-digit level. Statistics for 2004 will be based on both the old and new classifications, and it is planned that the old classification will be discontinued after 2004.

The national classification of products used in the Republic of Belarus is compatible with the two-digit level of the Classification of Branches of the Economy. Products within agriculture and industry correspond with the classification of products by activity at the one and twodigit levels. The Minstat plans to commence implementing the central product classification from January 2005 and this will be introduced over a five-year period. The Harmonised System is used in the compilation of exports and imports statistics. 
The classification of individual consumption by purpose (COICOP) is used in the household income and expenditure survey (HIES) and in the compilation of household final consumption expenditure (HFCE).

Data on the execution of the State budget are classified according to the Classification of the Functions of Government (COFOG).

\subsection{Basis for recording}

\subsubsection{Market prices are used to value flows and stocks}

The principal valuation rules, which are broadly in accordance with the 1993 SNA, are as follows:

- $\quad$ market prices are used in the valuation of goods and services;

- $\quad$ output for own use is valued at equivalent market prices;

- $\quad$ intermediate consumption is valued at actual purchaser's prices, excluding deductible value-added tax and including excise taxes;

- $\quad$ stocks of fixed assets are valued at purchasers' prices;

- $\quad$ consumption of fixed capital is mainly recorded at replacement values, after taking account of revaluations;

- dwelling services are valued according to the cost of operating and maintaining the dwelling stock (with no allowance for the opportunity cost of dwelling purchase);

- $\quad$ household expenditures are valued at purchasers' prices;

- $\quad$ imports and exports are valued f.o.b., consistent with balance of payments statistics; and

- $\quad$ foreign trade transactions in foreign currency are converted using the official exchange rates of the NBRB prevailing when the transactions take place. 


\subsubsection{Recording is done on an accrual basis}

Most transactions and flows are recorded on an accrual basis:

- $\quad$ capital formation is recorded in the period the production takes place;

- government revenues and expenditures are recorded in the government accounts on a cash basis. However, the NAD adjusts the data to convert them to an estimated accrual basis;

- work in progress is recorded in the period when it is produced; and

- international transactions are recorded at the time the goods enter or leave the economic territory as documented on the corresponding customs declarations.

\subsubsection{Grossing/netting procedures are broadly consistent with internationally accepted standards, guidelines, or good practices}

Grossing and netting procedures are generally in accordance with the 1993 SNA. Value added data are compiled and published on a gross basis and are available on a net basis; that is, net of consumption of fixed capital.

Data are collected from enterprises through the enterprise survey and questionnaires also include key data in respect of component establishments. However, transactions between establishments within the same enterprise are recorded on a net basis for the enterprise, rather than on a gross basis.

\section{Accuracy and reliability}

\subsection{Source data}

\subsubsection{Source data are obtained from comprehensive data collection programs that take into account country-specific conditions}

Article 12 requires the maintenance of a single State register of enterprises and organizations of all forms of ownership and appropriate interaction with other registers and lists of ministries and other central administrative authorities. However, this register is in fact maintained by the Ministry of Justice. A Central Statistical Register is compiled, for the purpose of collecting statistics, by the Minstat's Department of Statistical Planning and Statistical Monitoring, and is discussed later in this report.

The data used in compiling the national accounts statistics are derived from a wide variety of sources, including enterprise surveys (annual and quarterly), surveys for specific sectors of the economy, administrative data sources, and the HIES. 
The compilation process is highly dependent on the enterprise survey data, with the specific sectoral surveys being used mainly as supplementary sources. Administrative data comprise primarily budget execution data (from the MoF). Use is made of the balance of payments data compiled by the NBRB and merchandise trade statistics, which are also compiled by the NBRB using data from the State Customs Committee. HIES data are used as the main source for estimating household consumption expenditure and household production. Information about issued licenses is obtained from a number of ministries to assist in derivation of estimates of the nonobserved economy. Other data sources include:

- $\quad$ surveys of large farms and all state and statutory farms;

- $\quad$ surveys of subsidiary plots;

- $\quad$ surveys of construction;

- $\quad$ volume data from transport providers;

- $\quad$ surveys of financial intermediation and real estate; and

- $\quad$ survey of employed persons, wages, and employment.

The NAD reviews the questionnaires used for major surveys relevant to the national accounts on a regular basis, in order to ensure conformity with national accounts concepts and definitions.

Following are comments on the major data sources used in compiling the national accounts statistics:

\section{The Central Statistical Register}

The Central Statistical Register is maintained by the Minstat as the framework for conducting most of its surveys and censuses. The register covers all legal enterprises, and is assembled based on information supplied by registration authorities operating throughout the Republic of Belarus, including at local levels.

All new legal entities are required by law to register, within a prescribed period of time, with the appropriate registration authorities. All legal entities that make certain changes (such as their legal entity name, location address, form of legal organization or type of ownership) are also required to notify the appropriate registration authorities. All of this information is sent to the Minstat and forms the basis for compiling and updating the register on a continuing basis. 
The register is also updated with reference to relevant information obtained by the Minstat in the course of its regular censuses and surveys (for example, information on changes in name or form of ownership).

A number of different registration authorities currently exist, including at local levels, but the mission was informed that much of the responsibility for registration will be taken over by the Ministry of Justice. This is expected to result in more standardized systems and forms and more efficient practices for the Minstat in maintaining the register.

The Minstat plans to conduct a register updating survey in which entities currently on the register will be requested to check the information in respect of all characteristics contained on the register and inform the Minstat of all changes.

There are at present 90,000 legal entities listed on the register. The register includes public organizations, religious organizations, and groups of dachas (administered by village authorities), but subsidiary garden plots are excluded.

The register relates to legal entities and also contains information about component establishments within legal entities; these are also recognized as statistical units for certain survey purposes.

The concept of "small enterprises" is recognized for survey purposes. The definition of small enterprise varies across economic activities; for example, less than 100 employees for industry, less than 50 for construction, and less than 20 employees for retail trade.

The statistical units on the register are classified by main economic activity undertaken by the enterprise using the Classification of Branches of the Economy. However, the units are recoded to the General Classification of Types of Economic Activity, which is closely related to ISIC.

\section{Enterprise Surveys}

The annual and quarterly enterprise surveys cover all enterprises regardless of size. ${ }^{8}$ They are conducted according to the national classification of economic activities; that is, the Classification of Branches of the Economy for data up to and including 2003 and the General Classification of Types of Economic Activity from 2004 (with 2004 compiled on both bases). The concepts used in this survey are in accordance with the 1993 SNA.

The surveys are conducted at the enterprise level and basic information is also collected annually for component establishments within enterprises. A very detailed financial

\footnotetext{
${ }^{8}$ The use of sampling is under consideration for small enterprises that account for about 6 percent of total GDP, and the mission supports this initiative.
} 
questionnaire is used for large and medium sized enterprises and a shorter, but still comprehensive, four-page questionnaire is used for small enterprises.

The response rate for large and medium sized enterprises is virtually 100 percent. This is due to the penalties that may be incurred under the Law on State Statistics in the event of provision of incorrect information or failure to complete required questionnaires (see Section 0.1 .4 above).

Response rates for small enterprises are about 80 percent and, in addition, there are difficulties arising from insufficient knowledge about businesses that have commenced operation during the period, or that have ceased or changed the nature of their operations. This involves some estimation, usually on the basis of limited information. However, small enterprises account for only about 6 percent of total GDP.

Key data from enterprise surveys are checked against data from relevant sectoral surveys to assist in validity checking of overall results. Response rates for large and medium enterprises in surveys of individual sectors of the economy are also about 100 percent, while 80 percent is a reasonable indication of the response rate for small enterprises.

The enterprise survey questionnaires are sufficiently detailed to provide data for calculating gross output, intermediate consumption and gross value added, including details of the structure of intermediate consumption. The enterprise survey also provides data on investments in tangible fixed assets and intangible assets.

Data from the enterprise surveys cover the whole economy and special adjustments are subsequently made by the NAD for the nonobserved economy, as further discussed in 3.2.2 below.

\section{Household Income and Expenditure Survey (HIES)}

The HIES is the main data source used in compiling estimates of HFCE, a major component of GDP according to the expenditure approach. However, where relevant retail trade data are available, these are also examined and compared with the corresponding HIES data, commodity by commodity. On occasions, the retail trade data (adjusted to remove estimated sales to nonhousehold purchasers, such as for intermediate consumption) are used in place of the corresponding HIES data.

The HIES is conducted as a regular sample survey covering approximately 6,000 households. The sample selection is based on the 1999 population census with regular updating for population changes (births, deaths, and migration) based on administrative records.

Adjustments are also made, in the latter stages of the census cycle, with reference to electoral roll data. The sample is representative of large cities, smaller cities within oblasts, towns, and villages. 
The sample of households is selected so that each household has an equal chance of selection. Response is voluntary, but a response rate of 86 percent is achieved. Where a household drops out of the survey, mathematical procedures are applied to compensate for missing data. Households that change addresses are not followed to the new address unless they move within the same city and are easy to locate. Otherwise, such households are treated as nonresponse cases and their loss from the sample is compensated for by reweighting.

Collective households (such as elderly and nursing homes, student hostels, hotels, soldiers' barracks, hospitals, sanatoria, and prisons) are excluded from the HIES.

Corrections for nonresponse bias are made with reference to basic data collected for each household (including refusals) on characteristics such as place of residence, number in household, number of children under 18 years, number of elderly persons, and type of housing.

The sampled families are surveyed during a 12-month period, and each household is visited 17 times by an interviewer. Two types of information are collected.

- A diary is kept by each household to record daily expenditure for a 14-day period, including detailed descriptions of items, place of purchase and value, as well as daily consumption of food produced on the individual land plot (production for own consumption) or received as a gift. Sample families are equally distributed in to rotation groups throughout the quarter.

- An interview is used to obtain data on major household expenditures and incomes during the last quarter. This information is used to calculate annual expenditures and incomes.

Data produced from the HIES and used by the NAD include average monthly expenditures per household on 21 consumer goods and services items (based on COICOP). Food expenditure items are further subdivided into 26 items. The NAD also uses data collected and compiled regarding the share of food obtained from individual land plots.

Other HIES data used in the compilation of national accounts statistics include:

- $\quad$ household income by category;

- $\quad$ expenditure on rents and utilities;

- $\quad$ social benefits received; and

- own account fixed capital formation 
The following categories are considered to be under-represented: high income households; entrepreneurs and self-employed households; and homeless people. In compiling the HIES data, some adjustments are made at macro levels to compensate for such biases.

Household consumption expenditures and acquisitions of fixed assets are valued at purchasers' prices.

Expenditures on items such as tobacco products and alcohol are known to be understated, but corrections are not made for this when presenting HIES results. However, the NAD makes such adjustments in compiling HFCE.

Sampling errors for estimates are not routinely calculated, but users are alerted to data cells where the standard error of the estimate exceeds plus or minus 5 percent.

\section{Agricultural surveys}

Estimates for agricultural output and intermediate consumption are compiled using data collected by the Department of Agricultural Statistics within the Minstat. These data are compiled from a wide range of surveys covering topics such as: areas sown for crops, production of crops, livestock numbers and production, and materials used in agriculture. Financial data are also collected and compiled in the case of agricultural enterprises. Gross product estimates are published for agriculture and forestry separately, with no further disaggregation.

\section{Other data sources}

Data on government operations on the execution of the State budget are obtained from the MoF. These reports include data for both the national and local budgets. However, the data are not fully compatible with the definitions, scope, and classifications required for compiling the national accounts statistics. Hence, some adjustments are made by the Minstat. Reports on extra-budgetary operations, such as the social protection fund, are also available.

The balance of payments statistics are compiled by the NBRB. These statistics are used without adjustment by the Minstat in compiling the national accounts. The NBRB does not make adjustments for smuggling operations, but estimates the volume of shuttle trade based on household survey data and informal surveys of "open markets" (tax-advantaged retail trade operations). The NAD considers that smuggling is not greatly significant in the Republic of Belarus and that the incidence of border trade and shuttle trade has declined significantly in the last few years. In general, the NAD considers the balance of payments (including merchandise trade data) as compiled by the NBRB to be reliable.

The Minstat obtains reports from trade unions containing data on subsidies and payments in kind made to households at trade union expense. This covers services such as recreation and training expenses. 
A range of other data from administrative agencies is accessed for use in the national accounts estimates.

In general terms, the data sources and compilation methods for quarterly and annual estimates are similar, with differences being due primarily to the reliability of source data and the range and level of detail of the data available.

\subsubsection{Source data reasonably approximate the definitions, scope, classifications, valuation, and time of recording required}

The data from the various surveys are generally consistent with the definitions, scope, classifications, valuation, and time of recording required for national accounts statistics. The NAD is consulted in the design/redesign of questionnaires to ensure major national accounts requirements are met. Annual data are compiled on a calendar year basis and quarterly data are compiled for the period being assessed.

The data compiled from enterprise surveys are sufficiently detailed to allow adjustments to be made when necessary, to conform with national accounts concepts. Survey data on outputs of goods and services are valued at basic prices and intermediate consumption is valued at purchasers' prices.

Enterprises are classified by main type of economic activity according to the Classification of Branches of the Economy. The General Classification of Types of Economic Activity will be used as from 2004, and this is compatible with ISIC at the four-digit level. Data on government expenditure are available in sufficient detail to allow for the classification according to COFOG.

Two kinds of establishments exist within enterprises: those that maintain accounting records and those that do not maintain such records. Key financial data are collected from the first kind of establishment, and a range of nonfinancial data are collected from all enterprises.

\subsubsection{Source data are timely}

The national accounts for the Republic of Belarus are compiled on a regular quarterly and annual basis according to established timetables. The Minstat also compiles and publishes monthly estimates of GDP according to the production approach at both current and constant prices. The preliminary monthly GDP estimates are used to compile preliminary quarterly GDP estimates.

The preliminary monthly GDP estimates are based on output data for major economic activities including agriculture, industry, construction, distributive trade, transport and communications. The source data for the preliminary estimates are obtained on about the sixth to tenth day after the end of the reference month, and this timing is satisfactory for the 
compilation of preliminary monthly GDP estimates by the target date, which is the fifteenth day following the end of the reference month. ${ }^{9}$

Quarterly national accounts estimates based on actual quarterly data (as distinct from the partial data used for the preliminary monthly and quarterly GDP estimates) are produced by the one hundred and fifth day (twenty-first week) after the end of the reference quarter. In practice the estimates of GDP according to the production approach are available by the ninetieth day, but, are held until the finalization of GDP estimates according to the expenditure approach. The sole reason for the delay in finalizing the GDP expenditure approach estimates stems from the unavailability of balance of payments data from the NBRB until about ninety-five days after the end of the reference quarter.

Source data are available on a sufficiently timely basis from the major sources, including the enterprise surveys, the HIES, and the agricultural surveys. The major exception is the balance of payments data where the supply of data by the NBRB adversely affects the timeliness of the quarterly GDP estimates.

\subsection{Assessment of source data}

3.2.1 Source data-including censuses, sample surveys and administrative records-are routinely assessed, for example., for coverage, sample error, response error, and nonsampling error; the results of the assessments are monitored and made available to guide statistical processes

\section{Household income and expenditure survey}

The coverage of the HIES is satisfactory. The main exclusions are persons living in institutions, this practice is common in most countries. Sampling errors for HIES estimates are not routinely calculated, but users are alerted to data cells where the standard errors of the estimates exceed plus or minus 5 percent.

\section{Enterprise surveys}

The enterprise surveys cover all sectors of the economies. The surveys do not at present make use of sampling techniques although sampling of small enterprises is currently being introduced. The NAD makes various checks on trends in enterprise survey data. Data for large enterprises are checked for errors and inconsistencies, and, sometimes, the NAD raises queries directly with respondents in order to verify or amend reported data. There is limited

\footnotetext{
${ }^{9}$ In the case of State budget operations and certain paid services, the timing of supply of necessary data is such that estimates are incorporated based on the latest available month with adjustments for the most recent monthly CPI movement. Revisions are made in the following month.
} 
opportunity to make comparisons with data from the taxation authorities as the economic activity classification used by those authorities are compiled at a very broad level.

\section{Production approach procedures}

The estimates of output and intermediate consumption, and, hence, value added, are compiled and published for 24 components based on the Classification of Branches of the Economy, based mainly on data from the enterprise surveys. Following are comments on some important components of the GDP according to the production approach.

\section{Owner-occupied dwellings (dwelling services)}

In estimating dwelling services, the NAD uses detailed data on dwelling space classified by type of dwellings. These data are valued according to the cost of operating and maintaining the dwelling stock. The mission considers that this approach would result in some understatement of the estimate as it makes no allowance for the opportunity cost of purchasing dwellings. The NAD may wish to consider reviewing this approach and/or considering an alternative approach in which data on market rents for equivalent dwellings are applied to the data on dwelling space. The mission recognizes, however, that there may be difficulties in obtaining reliable and representative data on rental values from real estate agents and other sources.

\section{Work-in-progress}

Estimation of work-in-progress is broadly in accordance with the 1993 SNA. Data derived from the enterprise surveys are used to estimate output of large construction projects spanning more than one period. Estimates of standing timber and livestock for consumption are derived from agricultural surveys, but perennial crops are not estimated as work-inprogress, and the total output is allocated to the period of the harvest.

\section{Cash versus accrual recording}

Data are generally recorded on an accrual basis. Government transactions are adjusted for arrears in order to convert from a cash basis to an accrual basis.

\section{Expenditure approach}

The categories of expenditure on GDP are derived independently, but adjustments are made in order to reconcile GDP estimates. GDP according to the production approach is compared with GDP according to the expenditure approach. The former measure is generally considered to be the more reliable. GDP estimates according to the production and expenditure approaches are reconciled through the incorporation of the statistical discrepancy as a component of GDP according to the expenditure approach; that is, as a balancing item. 
The following comments relate to individual categories of GDP according to the expenditure approach:

\section{- $\quad$ HFCE}

- HFCE is estimated for quite detailed COICOP components. HFCE is estimated using primarily data from the HIES, but with some reference to data on retail sales.

- Expenditures on items such as tobacco products and alcohol are known to be understated and corrections are not made for this when presenting HIES results. However, the NAD makes independent estimates based on retail trade, production, and foreign trade statistics (the commodity flow method). Independent estimates are also made for textiles and for motor vehicles. HIES data are also used to make estimates of household production for own consumption; for example, owner-occupied dwellings (as discussed later).

- Own-account agricultural production is estimated from data collected by village councils on areas of sown crops, harvested crops, and livestock. The own-account production is valued using prices of agricultural products sold by agricultural companies in various geographic areas.

- Expenses of residents abroad are included in HFCE and expenditures of nonresidents in the domestic economy are excluded. This is consistent with the treatment in the balance of payments statistics.

- $\quad$ Government final consumption expenditure.

- Government final consumption expenditure is classified according to COFOG at the one-digit level for the annual estimates. Government final consumption expenditure excludes incidental sales.

- Gross fixed capital formation.

- Gross fixed capital formation is calculated on the basis of data from the enterprise survey. Data are collected on new construction activity as well as purchases of fixed assets. These are compared with estimates derived using a commodity flow approach based on production, imports, and exports.

- Valuables are not estimated. Items considered stores of wealth are excluded from consumption expenditure and capital formation to the extent that they can be identified. 


\section{- Inventories}

- Estimates of inventories are available from the enterprise survey. These estimates are adjusted for holding gains. Enterprises write-off inventories using the weighted average prices applied for each inventory. The NAD revalues inventories as at the beginning and end of the period, using average prices of the period. The NAD reports that the data provided by respondents, and the underlying methodology, are generally satisfactory, but that judgment is required when evaluating the results of the calculations before finalizing the estimates of changes in inventories.

\section{- $\quad$ Exports and imports of goods and services}

- Exports and imports of goods data are compiled by the NBRB on the basis of data from the State Customs Committee and in accordance with the balance of payments methodology Balance of Payments Statistics Manual, fifth edition (BPM5). These data are used by the NAD without further adjustment in the compilation of the national accounts.

- Travel expenditures by residents abroad are estimates based on arrivals and departures data obtained from the NBRB and other ministries, together with data from a quarterly sample survey of resident travelers conducted by the Minstat in which travelers supply information about expenditures abroad classified by broad categories.

- The accuracy of administrative data received from other ministries, trade associations, regulatory authorities are not routinely assessed. According to the Minstat, these data are obtained on a regular basis, and therefore are not checked. Even though these data sources are approved for dissemination to the Minstat and are signed by officials of these administrations, periodic checks by the Minstat are required.

- $\quad$ There are widespread concerns, expressed by users and the IMF's European Department, about the accuracy and reliability of much of the data produced by the Minstat, especially the GDP data and the industrial and agricultural production data. The mission's focus did not involve an audit of sources and actual data produced by the statistical agencies. If the basic inputs used in the statistical process are distorted, it follows that outputs will also be distorted, even if internationally recognized methodologies are applied.

- Despite the assurances by the Minstat about the legislative provisions that require accurate reporting by respondents, and the powers of the statistical authorities to inspect records and verify reported data, there remains the possibility that some respondents may misreport on their statistical questionnaires in order to show results that accord with government targets set. This is the view that has been expressed by 
some users. This view is refuted by officials at the Minstat. It is clear that these issues need to be fully explored in a separate technical assistance mission.

\subsection{Statistical techniques}

\subsubsection{Data compilation employs sound statistical techniques}

The data compilation techniques are generally sound.

\section{Production approach procedures}

Estimates of output, intermediate consumption and valued added are compiled and published for 24 categories of Classification of Branches of the Economy, based mainly on data collected in the annual and quarterly enterprise surveys.

Following are comments on specific issues related to the production approach:

- $\quad$ Agriculture

- Gross product estimates for agriculture are compiled using data collected by the Department of Agricultural Statistics within the Minstat. These data are compiled from a wide range of surveys covering topics such as areas sown for crops; production of crops; livestock numbers and production; and materials used in agriculture. Financial information is also collected and compiled in the case of agricultural enterprises. Gross product estimates are published for agriculture and forestry separately, with no further disaggregation.

- The output of agricultural activity undertaken by households is estimated based on data from household surveys and other information from the Department of Agricultural Statistics. Output data for agricultural products from subsidiary plots operated by persons in rural areas are based on information collected by village councils on areas covered by crops, yields, and livestock. The value of such output is estimated at prices of those products sold by agribusiness companies in oblasts of the Republic of Belarus.

- Work in progress

- The procedure for estimating work in progress is broadly in accordance with the 1993 SNA guidelines. Data are derived from the enterprise surveys to estimate large construction projects and output of large equipment. Estimates of growing crops, standing timber, livestock for consumption, and stocks of fish are largely based on data collected and compiled by the Minstat.

- The GDP estimates according to the income approach largely use the same data sources as those for GDP according to the production approach. Use is also made 
of data from the survey of employment and wages, and data from the Ministry of Labour and Social Protection regarding social benefits.

- $\quad$ Compensation of employees

- Compensation of employees comprises wages and salaries, employers' actual social contributions, and employers' imputed social contributions. The main data source for wages and salaries is the survey of employment and wages. Wages and salaries, as measured in the survey, include payments in kind. No adjustment is made to take account of "envelope salaries"; that is, wage payments that are not recorded in the accounts of businesses in order to avoid payment of social taxes. Based on recent research and analysis, the NAD considers that these are now of little significance.

- $\quad$ Consumption of fixed capital

- The basic data for measuring consumption of fixed capital is obtained from the fixed assets section of the enterprise surveys. The survey asks for data on the stock of assets at the beginning and at the end of the period, changes during the period, and depreciation. The survey records the stock of assets at historic prices after deduction of accumulated depreciation (that is, residual values). Data are obtained for various categories of tangible fixed assets. The NAD uses three different approaches to the measurement of consumption of fixed capital, and compares the results before finally determining the size of the estimate. Effective quite recently, legal entities are required by law to revalue their assets on January 1 each year. This has led to some convergence in the estimates on the different bases and a greater confidence in the resulting calculations.

\subsubsection{Other statistical procedures (for example, data adjustments and transformations, and statistical analysis) employ sound statistical techniques}

Sampling is not widely used in enterprise and sectoral surveys and grossing up is not an issue. Grossing-up techniques used in the HIES are soundly based.

In order to allow for nonrespondents to surveys, data are grossed up by the NAD using employment data and information from the central statistical register.

The NAD makes estimates to cover the legal activities undertaken in the nonobserved economy. These mainly comprise activities that are not reported or are under-reported by respondents to evade taxes and administrative controls.

The NAD is familiar with the various conceptual models for estimating the size and nature of the nonobserved economy (for example, the Organization for Economic Co-operation and Development (OECD) Handbook), and has received advice on conceptual and 
methodological issues from the Statistical Research Institute. However, the NAD does not have the resources to conduct any special surveys to supplement other available data.

The NAD mainly relies on comparing employment data from household and labor surveys with employment data from enterprise and sectoral surveys. This leads to refinements of the estimates of self-employed persons and, ultimately, to estimates of the size of the nonobserved economy classified by economic activities.

Currently, the NAD estimates that the nonobserved economy accounts for 10 to 11 percent of total GDP. This is lower than in many countries in Eastern Europe, but it is recognized that the very strict government controls in the Republic of Belarus (including tight controls over registration of legal entities and strong powers of enforcement and inspection by the Minstat) serve to reduce opportunities for nonobserved economic activity.

The reliability of the national accounts statistics could be enhanced by the allocation of specific resources in the NAD (for example, one person dedicated to estimation of the nonobserved economy). This would enable further analysis of the various data sources available and the conduct of some small scale surveys to supplement the available data. Some technical assistance on measurement of the nonobserved economy could also be of considerable benefit. Measurement of the nonobserved economy is covered in IMF training courses on national accounts. However, this topic is not specifically included in IMF technical assistance programs.

Fixed ratios derived from benchmark surveys are generally not used in compiling estimates of GDP according to the expenditure approach. However, there are a small number of exceptions.

\section{Specific quarterly GDP compilation issues}

Seasonal adjustment is undertaken using X-12 ARIMA.

\section{Issues relating to volume measures of GDP}

Both price deflation and quantity revaluation (extrapolation using volume indicators) approaches are used. Where price deflation is used, the double deflation approach is generally adopted.

The base year for constant price estimates is changed every five years in line with international guidelines. The present base year is 2000, covering the years 2000 onwards. The previous base year was 1995, covering the years 1995 to 2000 . Thus, the year 2000 is treated as the "overlap period," and it is possible to create a longer-term series by linking the two series. 
The constant price series for 1995 to 2000 are calculated on the base year $1995=100$. The constant price series for 2000 and subsequent periods are calculated on the base year 2000 $=100$. Thus, series for the year 2000 and the component quarters are compiled and published on two different bases, allowing the possibility of calculating longer-term time series.

The table below summarizes methods used to derive constant price estimates for the production approach.

\section{Production Account: Methods Used to Derive Constant Price Estimates (Using Existing Classification of Branches of the Economy)}

\begin{tabular}{|c|c|}
\hline Economic Activity & Method Used \\
\hline Industry & Extrapolation using volume index of production. \\
\hline Agriculture & $\begin{array}{l}\text { Extrapolation using volume indexes of agricultural output, } \\
\text { separately for public and private subsidiary plots; agricultural } \\
\text { services extrapolated by number of employees. }\end{array}$ \\
\hline Construction & $\begin{array}{l}\text { Extrapolation using volume indices of assets constructed during } \\
\text { period. }\end{array}$ \\
\hline Freight transport & $\begin{array}{l}\text { Extrapolation using a volume index of cargo transported (tons per } \\
\text { kilometer). }\end{array}$ \\
\hline Passenger transport & $\begin{array}{l}\text { Extrapolation using a volume index of passenger movement } \\
\text { (persons per kilometer). }\end{array}$ \\
\hline Communications & $\begin{array}{l}\text { Extrapolation using volume indices of communication services } \\
\text { provided to legal entities and to private consumers. }\end{array}$ \\
\hline Trade and catering & Extrapolation using volume indices of trade turnover. \\
\hline $\begin{array}{l}\text { Material supply (wholesaling of industrial } \\
\text { components, etc.) }\end{array}$ & Deflation using producer price index (PPI). \\
\hline $\begin{array}{l}\text { Procurement (purchase of agricultural and } \\
\text { other primary products) }\end{array}$ & Extrapolation using volume indices. \\
\hline Real estate & Deflation using the total consumer price index (CPI). \\
\hline Commercial market activities & Deflation using the total CPI. \\
\hline Geology (exploration) & Deflation using price index of building and construction work. \\
\hline Housing & Extrapolation using index of change in the volume of housing stock. \\
\hline Public utilities & Extrapolated using volume indices of production and services. \\
\hline Personal services & Deflation using price indices of various kinds of services. \\
\hline Science & Extrapolation using number of employees \\
\hline Finance, credit, and insurance & $\begin{array}{l}\text { FISIM deflated using total CPI; the remainder extrapolated using } \\
\text { number of employees. }\end{array}$ \\
\hline General administration and defense & Extrapolation using number of employees. \\
\hline
\end{tabular}


GDP by expenditure approach at constant prices

The methods used to derive expenditure on GDP at constant prices are summarized in the table below. These appear to be soundly based.

Expenditure based on GDP: Methods Used to Derive Constant Price Estimates

\begin{tabular}{|l|l|}
\hline \multicolumn{1}{|c|}{ GDP Component } & \multicolumn{1}{c|}{ Method Used } \\
\hline HFCE & CPI (at detailed levels). \\
\hline Government final consumption expenditure & $\begin{array}{l}\text { Goods: deflation using CPI. Services: extrapolation } \\
\text { using volume index of government employment. }\end{array}$ \\
\hline Gross fixed capital formation & Deflation using investment price indices and PPIs. \\
\hline Change in inventories & Deflation using PPIs for industry and agriculture. \\
\hline Exports and imports of goods & Revaluation using indices of physical production. \\
\hline Exports and imports of services & $\begin{array}{l}\text { Use implicit deflators derived for exports and imports } \\
\text { of goods. }\end{array}$ \\
\hline
\end{tabular}

\subsection{Assessment and validation of intermediate data and statistical outputs}

\subsubsection{Intermediate results are validated against other information where applicable}

Data derived from the enterprise surveys are assessed against data on output derived from other primary and secondary sources, including administrative statistics and selected data from the HIES. In compiling household consumption estimates, comparisons are made between HIES estimates and data from the retail trade survey and other sources.

\subsubsection{Statistical discrepancies in intermediate data are assessed and investigated}

The various survey departments within the Minstat are responsible for validity checking of their data and undertaking comparisons with external sources where relevant. In compiling the national accounts statistics, the NAD uses balance of payments data without adjustment. Data from the State budget report are used with certain adjustments to accord with the accrual basis.

In compiling estimates of HFCE the NAD makes comparisons of HIES and retail trade data as far as possible, and also makes estimates using the commodity flow approach.

In general, discrepancies in intermediate data are assessed by the NAD and major differences investigated. This results in the adjustment of data from the enterprise survey or selective replacement with data from alternative sources. 


\subsubsection{Statistical discrepancies and other potential indicators of problems in statistical outputs are investigated}

GDP estimates according to the production and expenditure approaches are reconciled through the incorporation of the statistical discrepancy as a component of GDP according to the expenditure approach, that is, as a balancing item. There has been no systematic analysis of quarterly and annual trends in the statistical discrepancy over time, and the mission suggests that this may prove useful in determining possible error sources.

The Minstat compiles annual input-output tables, which are used by the NAD as a basis for re-examining the validity of the already published national accounts data for that year. The Minstat does not revise annual national accounts data following finalization of the inputoutput tables, but takes note of significant discrepancies for reference in compiling national accounts data for subsequent years.

\subsection{Revision studies}

\subsubsection{Studies and analyses of revisions are carried out routinely and used internally to inform statistical processes (see also 4.3.3)}

The NAD has carried out some studies of revisions. It would be very desirable for the NAD to make such studies, on a regular basis and over a period of years, of the direction and magnitude of revisions occurring between preliminary and final estimates (quarterly) and between preliminary and final estimates (annual), and endeavor to ascertain systematic errors and biases in data sources and methods; for example, consistent under-estimation of specific components in the advance GDP estimates when compared with the subsequent estimates.

\section{Serviceability}

\subsection{Periodicity and timeliness}

\subsubsection{Periodicity follows dissemination standards}

The GDP estimates are disseminated quarterly, however, the Minstat is not at present meeting the Special Data Dissemination Standard (SDDS) requirement (one quarter) due to the late finalization of the balance of payments statistics. However, the Minstat publishes monthly industrial production indices within two weeks of the end of the month, well within the SDDS requirement.

Detailed annual GDP estimates are published 15 months after the end of the reference year in the publication National Accounts of the Republic of Belarus. Summary data are produced 11 months following the end of the year and made available to selected government users. 


\subsubsection{Timeliness follows dissemination standards}

Timeliness for the GDP estimates does not meet the SDDS requirement because the "full" quarterly GDP estimates are published on the one hundred and fifth day (that is, 15 weeks) following the end of the reference quarter. However, the Minstat publishes monthly indices of industrial production within two weeks of the end of the month. Accordingly, the Minstat could take a flexibility option in respect of the timeliness of the quarterly GDP estimates. ${ }^{10}$

From the viewpoint of users, however, it would be desirable if the Minstat could publish the full quarterly GDP estimates by about the ninetieth day following the end of the quarter.

GDP data according to the production approach are compiled and available by the ninetieth day following the end of the quarter. However the release of the publication is held until the one hundred and fifth day so that the GDP data according to the expenditure approach can be incorporated. This also involves balancing the two basic approaches. The sole reason for delays with the expenditure approach results from the late receipt of balance of payments data from the NBRB. In fact, all required data, apart from the balance of payments data, are available on around the eighty-fifth to ninetieth day following the end of the quarter. It would be desirable if the Minstat and the NBRB could reach an agreement for the supply, to the Minstat, of the required balance of payments data at an earlier stage of each quarter with a view to advancing the release of the quarterly GDP by several days.

\subsection{Consistency}

\subsubsection{Statistics are consistent within the dataset}

The GDP estimates according to the production approach, are considered by the NAD to be more reliable than those made according to the expenditure approach. GDP estimates according to the production and expenditure approaches are reconciled through the incorporation of the statistical discrepancy as a component of GDP according to the expenditure approach, that is, as a balancing item. However, in reconciling the two basic approaches, the other components of the expenditure approach are reviewed at the final compilation stage, including reference to recent trends in such components, and adjustments are sometimes made to such components before determining the size of the statistical discrepancy. In the same way, the components of GDP according to the production approach are also reviewed and sometimes adjusted.

Analysis of the data over the years 1997 to 2002 shows that the statistical discrepancy in terms of percentage of annual GDP has ranged between minus 0.2 percent and 1.6 percent. The statistical discrepancy in terms of percentage of quarterly GDP has ranged between minus 0.2 percent and 5.0 percent. These are within acceptable limits.

\footnotetext{
${ }^{10}$ However, the industrial production indices are not published as indices on a standard reference base, although such series are available.
} 
There is a difference in presentation between the quarterly estimates at current and constant prices. The statistical discrepancy is explicitly shown as a balancing item in the current price estimates. However, the statistical discrepancy is included in net exports in the constant price estimates and not explicitly shown. This has been done for some years because of apparent distortions in the data series. Recently, the NAD commenced a review of this approach. The mission supports this review and in principle considers that the statistical discrepancy should be published explicitly in the constant price estimates.

\subsubsection{Statistics are consistent or reconcilable over a reasonable period of time}

The NAD made revisions to national accounts data for the years 1990 to 1999 following a joint study with Goskomstat, Russian Federation, of national accounts methodology. These revised data for the Republic of Belarus were presented on a consistent basis and published in a publication entitled National Accounts of the Republic of Belarus in 2001. Revisions were also made and published for the component quarterly series for the years 1992 to 1999 . The mission was informed, however, that there were no significant practical differences between the revised annual and quarterly series and those published initially.

The constant price estimates are presented on a base $1995=100$ (that is, in terms of 1995 prices) for the years 1995 to 2000 and on a base $2000=100$ for the years 2000 onwards. Thus, the year 2000 is regarded as a link period in which data are available on both bases. It is, therefore, possible for users to make their own calculation of a long-term series through a simple mathematical calculation.

It is noted that the constant price estimates of GDP are shown in terms of 1995 and 2000 prices and that the series are also expressed in terms of the prices of the previous year (annual data), and in terms of the prices of the corresponding quarter of the previous year (quarterly data). The NAD states that some users prefer this approach as it is a more traditional approach, from the viewpoint of former Soviet Union countries, and one that they have become accustomed to, while other users prefer a series on a consistent basis for a number of years. The NAD also indicates that there is considerable confusion among users on this issue.

The Minstat should carefully explain the two different approaches in national accounts publications in an attempt to reduce user confusion on the issue.

\subsubsection{Statistics are consistent or reconcilable with those obtained through other data sources and/or statistical frameworks}

The statistics are consistent and reconcilable with other major data sources. In the case of the balance of payments and merchandise trade statistics, the data compiled by the NBRB are used in the national accounts compilation without adjustment. The government finance statistics (GFS) are partially adjusted from a cash basis to an accrual basis. The estimates of 
HFCE are broadly based on the HIES, but adjustments are made for some items such as tobacco products and alcohol. There are no other significant instances of adjustment.

\subsection{Revision policy and practice}

\subsubsection{Revisions follow a regular and transparent schedule}

GDP data are compiled on a cumulative monthly basis (that is, year to date) based on data for major economic activities and imputations for the other economic activities. The initiative of the Minstat in compiling these series needs to be recognized. However, due to the methodology used to collect the data, including reporting by respondents of revisions to past cumulative data, the Minstat is not able to compile discrete monthly series from these data. ${ }^{11}$

The Minstat is able, however, to compile discrete quarterly GDP estimates from the cumulative monthly information. ${ }^{12}$ Discrete quarterly GDP estimates are also subsequently compiled based on actual quarterly data obtained for all economic activities (production approach) and reconciled with GDP estimates according to the expenditure approach.

The initial quarterly estimates are revised following completion of the GDP estimates based on actual quarterly surveys data, and further revisions are made following completion of the annual national accounts data and the reconciliation of quarterly and annual estimates. This occurs 13 months following the end of the reporting year.

Revisions may be made to quarterly estimates following identification of errors that may have occurred in earlier data, but such revisions rarely occur in practice. However, the NAD seeks to learn from the experience by identifying reasons for revisions (for example, incorrect reporting, incorrect classification, inappropriate methodology, etc.) in order to improve data accuracy or reliability in subsequent periods.

Preliminary annual GDP data are compiled and published, based on the component quarterly data. The annual data are then revised following compilation of annual estimates based on actual annual data received from source departments within the Minstat and from other sources. However, further revisions to annual national accounts do not occur, even following the finalization of the annual input-output tables.

The revision schedules are followed closely by the NAD, and the various dates are generally closely adhered to. The schedules have been documented for the benefit of staff and are also incorporated in the Methodological Guidelines on Statistics (2003).

\footnotetext{
${ }^{11}$ For example, a respondent may notify a revision to January-April data when reporting data for May, and the Minstat cannot determine which month (or months) have been revised by the respondent.

12 The quarterly estimates compiled from this "advance system" are made available about the fifteenth day following the end of the final month of each quarter.
} 


\subsubsection{Preliminary and/or revised data are clearly identified}

Preliminary data are clearly identified as such in the quarterly national accounts publication disseminated by the Minstat. There is no such note for annual national accounts data, except for the annual data for the latest year, as published in the quarterly publication. This is sufficient because annual data are not revised following the publication of annual estimates based on actual annual data.

The Minstat uses a standard notation to identify revised data in some of its publications. However, this convention is not used in most of the national accounts publications and revised data generally are not readily apparent to users. Only those users familiar with national accounts revisions policy would be in a position to identify which series may have been revised. This is an important issue for quarterly series, but not so relevant for annual series.

\subsubsection{Studies and analyses of revisions are made public (see also 3.5.1)}

Revisions were made to national accounts data from 1990-1999. These revised series were published, but no explanatory notes were provided in the publication. The Minstat informed the mission that this was not done as the revisions were not significant. Apart from this, systematic studies and analyses of revisions made in the normal course of national accounts compilation are not conducted, and, hence, there are no such studies to be made public.

\section{Accessibility}

\subsection{Data accessibility}

5.1.1 Statistics are presented in a way that facilitates proper interpretation and meaningful comparisons (layout and clarity of text, tables, and charts)

Annual national accounts data are published in the Statistical Yearbook and in the annual publication National Accounts of the Republic of Belarus. These publications are in both Russian and English. A summary of annual national accounts data is also released to governmental users; this is not an official publication. Some basic national accounts statistics are also published on the Minstat's web site.

Quarterly national accounts data are published in the Quarterly Estimates of Gross Domestic Product and, in more summary form, in the Quarterly Statistical Bulletin. These two publications are in both Russian and English. These show GDP estimates at current and constant prices for recent quarters.

GDP data are also produced on a cumulative basis. Hence, GDP is not compiled on a discrete monthly basis, and it follows from this that users are unable to calculate movements in GDP over defined periods, such as April 2004 compared with April 2003. The mission considers 
that the primary focus should be on developing an appropriate methodology for compiling estimates for each individual month, but recognizes that this is not possible under the existing accounting law.

Input-output tables are published in the annual publication Input- Output Tables. The latest issue contains data for 2001 and was published in 2003.

Publication tables are in general clearly presented although the users' confusion about the various estimates at constant prices indicates that there is scope for rationalizing the data published and/or clearly explaining to users the different bases. The publications rely almost entirely on tabular presentation with practically no use of graphs and charts. There are descriptions of concepts in the publications, but very little comment about data sources and methods. There are also no analytical comments about major changes occurring in the data from period to period.

The mission considers that users would benefit considerably from the provision of information about data sources and methods and from analytical comment about changes from period to period. This would also assist in improving the image of the Minstat as a professional, impartial, and relevant statistical organization

The Methodological Guidelines on Statistics contain much more detailed information about concepts, sources, and methods, but this has very limited circulation. The publication contains no explanatory notes about the revised methodology and its effects on the various series compiled. However, these matters were discussed with some major users at the time of publication. Similarly there are no analytical comments that highlight major trends for the guidance of users.

\subsubsection{Dissemination media and format are adequate}

Dissemination practices are generally sound. The data are disseminated on the official web site of the Minstat, in specific annual and quarterly national accounts publications, and in general statistical publications. The web site and most publications present the information in both Russian and English.

National accounts data are also available on request in electronic form (email, diskettes and compact disk). This availability is publicized in the Catalog of Statistical Publications. However, it is not advertised in national accounts publications.

The data on the Minstat's web site are provided in html format, which can be converted into Word or Excel format.

The mission notes that the distribution lists for national accounts publications are quite small; about 85 users receive the publications. 


\subsubsection{Statistics are released on a preannounced schedule}

The national accounts data are disseminated according to an advance release calendar disseminated by the Minstat for the upcoming three months. The advance release calendar is published on the Minstat's web site. The list of published materials and their dates of publication are shown in the annual "Plan of Production of Statistical Materials," developed by the Minstat. In addition, the Catalogue of Statistical Publications shows the expected month of publication for each listed publication. The Minstat is generally able to adhere to the target dates for release.

\subsubsection{Statistics are made available to all users at the same time}

All national accounts data are distributed simultaneously to all users through the internet and national accounts and general statistical publications, on the preannounced date of publication.

\subsubsection{Statistics not routinely disseminated are made available upon request}

Unpublished, nonconfidential sub-aggregates are made available to users upon request, but this availability is not well publicized. The Minstat has agreements with some universities and research institutions concerning the supply of unpublished nonconfidential data.

\subsection{Metadata accessibility}

5.2.1 Documentation on concepts, scope, classifications, basis of recording, data sources, and statistical techniques is available, and differences from internationally accepted standards, guidelines, or good practices are annotated

Descriptions of national accounts concepts are shown in the relevant publications and on the Minstat's web site. This web site includes some metadata compiled according to SDDS guidelines. However, little or no information is presented in publications about sources of data and methods used. For example, the publications do not comment on aspects of the general reliability of the source data, including rates of response, sampling methods and standard errors (where relevant), and possible biases.

However, the Methodological Guidelines in Statistics (2003), which relates to all major Minstat data products, contains detailed information about concepts, sources, and methods. This has a limited circulation. Only 100 copies were printed, but extracts for particular sections such as the national accounts can be provided to users on request. This is the second issue of the Methodological Guidelines. The first issue was published in 1999.

Methodological Guidelines do not highlight differences and deviations from internationally accepted standards or guidelines, such as the economic activity and product classifications currently in use. 


\subsubsection{Levels of detail are adapted to the needs of the intended audience}

In general, the metadata for national accounts are very limited and require considerable extension in order to assist users in understanding the basis for compiling the national accounts statistics. The exception is the Methodological Guidelines in Statistics (2003), which contains a very detailed explanation of concepts, sources, and methods. There is a strong need for supplying a more complete description of concepts, sources, and methods in publications, but not at the level that appears in the Methodological Guidelines.

The mission considers that users would benefit considerably from the provision of information about data sources and methods and from analytical comment about changes from period to period. This would also assist in improving the image of the Minstat as a professional, impartial, and relevant statistical organization

\subsection{Assistance to users}

\subsubsection{Contact points for each subject field are publicized}

The name and telephone number of the head of the NAD are publicized in all national accounts publications and on the Minstat's web site. The head is available to assist users requiring further data or explanations.

\subsubsection{Catalogs of publications, documents, and other services, including information on any changes, are widely available}

The Catalog of Statistical Publications is published annually. It is made available as a booklet and is also posted on the Minstat's web site. It is prepared in Russian and English. When first printed, the Catalog is sent to a list of about 250 users, including about 35 users of national accounts statistics. The Catalog is placed in libraries of the Minstat in Minsk and the six oblasts. The Catalog also provides information for ordering publications and order forms are sent to about 500 users about a month prior to the issue of the Catalog.

The Catalog provides brief comments about the contents of each publication and the language of the publication. It does not indicate prices of publications. Due to rapid inflation, which is currently about 30 percent per year, the prices are contractual, to be negotiated at the time of purchase.

The Minstat has a Department of Working with Users and Statistics Information, which is responsible for providing information and products to users. The Minstat has a library, which is open to the public, and a bookshop, both of which are located in the headquarters building. The full range of data and metadata are not available from the regional offices of the Minstat. For example, any user located outside Minsk who requires a national accounts publication must make a request in writing to the Department of Working with Users at the Minstat headquarters. 
The publications show the site address and the email address of the Minstat, and the name and telephone number of the Head of the NAD.

While procedures are in place to assist and inform users about the Minstat's products, some users have commented that they are not completely satisfied with the quality of the service provided, usually from the viewpoint of timeliness and availability of metadata. 
Table 1. Republic of Belarus: Data Quality Assessment Framework (July 2003): Summary of Results for National Accounts

(Compiling Agency: Minstat)

\begin{tabular}{|c|c|c|c|c|c|c|c|}
\hline \multirow{2}{*}{\multicolumn{2}{|c|}{ Element }} & \multirow{2}{*}{ NA } & \multicolumn{4}{|c|}{ Assessment } & \multirow{2}{*}{ Comments } \\
\hline & & & $\mathrm{O}$ & LO & LNO & NO & \\
\hline 0. & \multicolumn{7}{|l|}{ Prerequisites of quality } \\
\hline & Legal and institutional environment & & \multirow[b]{4}{*}{$\mathrm{X}$} & $\mathrm{X}$ & \multirow{4}{*}{$\mathrm{X}$} & & $\begin{array}{l}\text { Limited procedures to ensure confidentiality maintained where small numbers } \\
\text { of entities concerned }\end{array}$ \\
\hline 0.2 & Resources & & & $\mathrm{X}$ & & & Improved computing facilities required \\
\hline 0.3 & Relevance & & & & & & No user advisory committee and user surveys \\
\hline 0.4 & Other quality management & & & & & & \\
\hline \multicolumn{8}{|c|}{ 1. $\quad$ Assurances of integrity } \\
\hline 1.1 & Professionalism & & \multirow[t]{2}{*}{$\mathrm{X}$} & & \multirow{3}{*}{$\mathrm{X}$} & & \multirow{3}{*}{$\begin{array}{l}\text { Advance notice only given informally; government access not publicly } \\
\text { identified }\end{array}$} \\
\hline 1.2 & Transparency & & & & & & \\
\hline 1.3 & Ethical standards & & $\mathrm{X}$ & & & & \\
\hline 2. & \multicolumn{7}{|l|}{ Methodological soundness } \\
\hline 2.1 & Concepts and definitions & & $\mathrm{X}$ & & & & \multirow{4}{*}{$\begin{array}{l}\text { Economic activity and product classifications do not yet meet international } \\
\text { standards, but soon to be implemented progressively }\end{array}$} \\
\hline 2.2 & Scope & & $\mathrm{X}$ & & & & \\
\hline & Classification/sectorization & & & $\mathrm{X}$ & & & \\
\hline 2.4 & Basis for recording & & $\mathrm{X}$ & & & & \\
\hline 3. & \multicolumn{7}{|l|}{ Accuracy and reliability } \\
\hline 3.1 & Source data & & \multirow{5}{*}{$\mathrm{X}$} & $\mathrm{X}$ & \multirow{5}{*}{$\mathrm{X}$} & & Balance of payments data are late \\
\hline & Assessment of source data & & & & & & $\begin{array}{l}\text { Reservations about reliability of national accounts and some sectors (e.g., } \\
\text { industry and agriculture) }\end{array}$ \\
\hline 3.3 & Statistical techniques & & & $\mathrm{X}$ & & & Further attention to measurement of nonobserved economy desirable \\
\hline 3.4 & $\begin{array}{l}\text { Assessment and validation of intermediate data and statistical } \\
\text { outputs }\end{array}$ & & & & & & \\
\hline 3.5 & Revision studies & & & $\mathrm{X}$ & & & Studies of direction/magnitude of revisions over time are not made. \\
\hline 4. & \multicolumn{7}{|l|}{ Serviceability } \\
\hline & Periodicity and timeliness & & & $\mathrm{X}$ & & & Quarterly GDP does not meet SDDS timeliness. \\
\hline & Consistency & & & $\mathrm{X}$ & & & $\begin{array}{l}\text { Stat discrepancy treated differently in constant price estimates compared with } \\
\text { current prices }\end{array}$ \\
\hline & Revision policy and practice & & & $\mathrm{X}$ & & & $\begin{array}{l}\text { Revised quarterly data not clearly identified; revisions } 1990 \text { to 1999, but no } \\
\text { explanations }\end{array}$ \\
\hline \multicolumn{8}{|c|}{ 5. $\quad$ Accessibility } \\
\hline & Data accessibility & & & $\mathrm{X}$ & & & \\
\hline & Metadata accessibility & & & $\mathrm{X}$ & & & Publications have limited metadata and no analytical comments \\
\hline 5.3 & Assistance to users & & & $\mathrm{X}$ & & & Some users not completely satisfied with assistance provided \\
\hline
\end{tabular}

(C) International Monetary Fund. Not for Redistribution 


\section{Price Statistics (Consumer Price Index)}

\section{Prerequisites of quality}

\section{$0.1 \quad$ Legal and institutional environment}

\subsubsection{The responsibility for collecting, processing, and disseminating the statistics is clearly specified}

The production of official statistics in the Republic of Belarus is the responsibility of the Ministry of Statistics and Analysis of the Republic of Belarus (Minstat). The Minstat operates under the Law of the Republic of Belarus on State Statistics (the Law on State Statistics), which was adopted by the House of Representatives on January 11, 1997, approved by the Council of the Republic on January 30, 1997, and signed by the President of the Republic of Belarus on February 17, 1997. The Law on State Statistics was developed in line with recommendations of Eurostat.

The Minstat is accountable to the Council of Ministers of the Republic of Belarus and operates under Belarusian legislation. It has its own settlement account and other accounts with banking institutions.

The State statistical system for the Republic of Belarus comprises the Minstat, and oblast (including City of Minsk), district and city agencies of statistics. The Minstat and its agencies in oblasts, cities and regions, and other organizations subordinated ${ }^{13}$ to the Minstat constitute a single system of State statistics for the Republic of Belarus.

The Minstat is headed by a Minister who is appointed under the Constitution by the President. The Minister is a member of the government and is empowered to issue directives and instructions that are binding on subordinate statistical bodies within the Minstat.

The Minstat has a Board of Management that comprises the minister (as chairman), his deputies, and other staff. The Board of Management considers and determines fundamental issues relating to the organization of statistical activities (for example, methodology, questionnaires, release practices, staff appointments and terminations, performance at regional levels, organization structure, statistical program priorities, and budgetary allocations). The Minister of Minstat, as a member of the Cabinet of Ministers, reports to the government concerning major decisions made by the Board.

\footnotetext{
${ }^{13}$ Subordinate organizations include main computing center, Statistical Research Institute Computing Centers of Oblast (City of Minsk) department of statistics.
} 
There is also an Inter-Agency Council for State Statistics, established under a government resolution, which makes proposals on methods and questionnaires, and considers proposals for the inclusion in the statistical work plan (discussed below). The Inter-Agency Council for State Statistics reviews proposals submitted to it, and makes recommendations that are forwarded to the Council of Ministers for decisions about financing.

The Inter-Agency Council for State Statistics comprises the Deputy Prime Minister of the Republic of Belarus (Chairman), the Minister of the Minstat, the Minister of Labor and Social Protection, the Minister of Justice, the Deputy Ministers of Industry, Finance, and Economy, and representatives of the Academy of Science and other bodies. The composition of the Council allows it to take direct account of user requirements to some extent, but it is not very broadly based in terms of membership compared with models in some countries. Due to its membership, it functions as an advisory body rather than an executive decision making body. The reports of the Council are publicly available documents.

Article 3 of the Law on State Statistics specifies the basic tasks of state statistics as:

- $\quad$ collecting, processing, compiling and analyzing economic and social statistics, using scientifically based statistical methodology; and

- disseminating statistical information to governmental authorities and other users.

The Minstat, its offices in the oblasts, cities, and rayons, and the other subordinate organizations constitute the uniform system of state statistical authorities of the Republic of Belarus. The Minstat is subordinate to the Council of Ministers of the Republic of Belarus. The Minstat acts on the basis of the provisions of the Minister of the Minstat, as approved by the Council of Ministers of the Republic of Belarus, and other regulatory acts.

Article 10 provides that State statistical authorities have the right to:

- receive statistical data, in the manner established by the central statistical authority, from legal entities, and entrepreneurs who have not formed a legal entity;

- $\quad$ verify the reliability of statistical data and, where distortions are found, to give mandatory instructions concerning their elimination and appropriate corrections in aggregated statistical data; and

- $\quad$ require entities to comply with the requirements of the Law, including entities that are not legally incorporated. 
Under Article 11, ministries and other central administrative authorities that produce state statistics shall have the right to:

- $\quad$ receive and use statistical data "in the manner specified by Articles 5, 8, and 9 of this Law"; and

- monitor the status of primary accounting and statistical reporting, and check the authenticity of statistical data reported.

Under Article 12, State statistical authorities are required to:

- $\quad$ organize state statistical observations and provide government authorities with reliable and objective statistical information on the socio-economic situation of the country;

- ensure the accessibility of summary statistical information for a wide range of users, and give necessary explanations and comments on the methodology of producing statistical data, including through the mass media; and

- $\quad$ ensure that the primary data collected by state statistical authorities are not subject to disclosure and are used exclusively for statistical purposes.

The Minstat is required to provide State bodies and other users with reliable and objective economic and social statistics, including national accounts statistics. It also provides explanations about methodologies for compiling data.

Section 34 of the Constitution of the Republic of Belarus provides that citizens have the right to receive information on the activities of State bodies, and those bodies shall provide citizens with an opportunity to obtain access to the materials pertaining to their rights and legitimate interests. This Section of the Constitution is endorsed by Article 12 of the Law on State Statistics. The extensive publication program of the Minstat is consistent with this provision in the Constitution.

Within the Minstat, the Department of Price Statistics (DPS) is responsible for the compilation of the Consumer Price Index for the Republic of Belarus.

\subsubsection{Data sharing and coordination among data-producing agencies are adequate}

The Law on State Statistics provides for data sharing and coordination of statistical activities.

- $\quad$ Article 5 provides that ministries and other central administrative authorities shall compile state statistics in accordance with the forms and methodological instructions approved by the central statistical authority. 
- $\quad$ Article 7 provides that State statistical observations (including state administrative data, one-time assessments, censuses, and sample surveys) shall be carried out by state statistical authorities, ministries, and other central administrative authorities on the basis of the methodological instructions, programs, and forms of statistical reporting approved by the central statistical authority.

- $\quad$ Article 10 states that decisions of the state statistical authorities, within their competence, shall be mandatory for implementation by ministries, other central administrative authorities, local executive and administrative authorities, legal entities and other individual entrepreneurs.

- Article 13 requires ministries and other central administrative authorities that compile state statistics to:

- ensure the collection, processing, and reliability of statistical data in their areas of responsibility; and

○ supply to state statistical authorities, on their demand, statistical data specified by state statistical reporting.

The Department of Statistical Planning and Statistical Monitoring within the Minstat is responsible for ensuring effective coordination between the Minstat and the ministries with the primary responsibility for compiling the statistics and other data producing agencies.

\subsubsection{Individual reporters' data are to be kept confidential and used for statistical purposes only}

Article 9 provides that information containing state and commercial secrets shall not be subject to disclosure, and stipulates that statistical information shall be used for State and scientific purposes and for informing the public. This provides for the protection of the privacy of individual data submitted by, and in respect of, persons.

Article 15 specifies that employees of State statistical authorities, ministries, and other central administrative authorities who produce state statistics must not violate the requirements of the Law concerning the collection and use of statistical data and for concealing and distorting them. Employees of the Minstat are required to sign a contract at the commencement of employment that they will not divulge State secrets. This requirement is reinforced in a Duty Manual supplied to each staff member. All computers are password protected. The Minstat's officials informed the mission that there has been no instance where an employee has violated this requirement of the Law.

Article 12 further reinforces the requirement for confidentiality of individual data supplied. State statistical authorities are required to preserve state and commercial secrecy, and to ensure that primary data obtained from legal entities or physical persons are used exclusively for statistical purposes. Similarly, Article 13 requires that ministries and other central 
administrative authorities that produce state statistics shall preserve state and commercial secrecy. In addition, article 21 of the Law on Civil Service in the Republic of Belarus (law No. 204-3 of June 14, 2003) states, among the obligations of civil service, that civil servants must not disseminate state secrets entrusted to them, and the disclosure of state secrets could result in their dismissal of the civil service.

The mission discussed with senior officials from the Minstat the question of release of data where only a small number of entities are involved. The mission was informed that, where one or two nongovernment enterprises contribute to a statistical cell, the Minstat ensures that such data remains confidential, but that these rules are not applied where government enterprises are concerned. The mission considers that more comprehensive procedures are required to guide staff in ensuring that statistics released do not disclose information relating to an individual entity, either directly or by deduction. This is important in order to maintain public confidence in the Minstat.

The Minstat's officials indicated that there are situations where an entity may give written consent for the disclosure of information about the entity, but that the Minstat seeks to avoid too many such situations from a workload point of view. The mission observed, however, that it is not clear from the legislation that the Minstat has the authority to release individual data with the consent of the entity concerned. This is a legal right of statistical agencies in some other countries and the mission considers that the legislation in the Republic of Belarus should be clarified concerning this right, even though it is seldom exercised.

The Minstat should consider seeking an amendment to the Law on State Statistics enabling the Minstat to release data that would otherwise be confidential with the consent of the entity (entities) involved. This provision would need to be used very sparingly, but would allow publication of significant data where only one or two entities are involved; e.g., the production of a specific commodity by one or two producers.

All survey questionnaires state clearly, on the top of the front page, that all information collected by the Minstat will be kept confidential and used for statistical purposes only.

Officials of the Minstat assured the mission that there is adequate physical security for all premises, adequate physical protection of computing facilities, and various encoding procedures, all of which serve to assist in protecting the confidentiality of the data stored in the premises of the Minstat and guard against unlawful access to data.

The staff is sensitive to issues regarding data confidentiality and takes appropriate measures to ensure that respondents' information are guarded. All computers are password protected, and a local network is provided only for prices information.

Confidentiality agreements are signed by CPI specialists. CPI data are presented only in aggregated and consolidated manner for researchers and other persons requesting data. 


\subsubsection{Statistical reporting is ensured through legal mandate and/or measures to encourage response}

There is a clear legal mandate for collection of information for statistical purposes. Article 8 requires that all legal entities, and entrepreneurs who have not formed legal entities, shall submit statistical reports free of charge, observing the forms, deadlines, and addresses approved by the central statistical authority. Article 8 also provides that questionnaires and deadlines for statistical reporting by banks, free of charge, shall be approved by the central statistical authority as agreed with the National Bank of the Republic of Belarus (NBRB).

Under Article 14, officials and entrepreneurs carrying out their activity without forming a legal entity who evade the mandatory submission of statistical data to state statistical authorities and also to ministries and other central administrative authorities that produce state statistics, or submit them in a distorted form or in violation of the established schedules, are in breach of the legislation. In addition, damage caused as the result of the submission of distorted statistical data shall be subject to penalty under legislation of the Republic of Belarus.

The Minstat's employees are entitled to visit business entities in order to check the accuracy of the data reported in State statistical questionnaires. Such inspections are selectively undertaken by the Minstat, sometimes involving specialists of branch ministries. These measures result in a high level of cooperation and the collection of reliable data. In 2003, inspections on data accuracy were carried out at 3,700 business entities. Amendments were incorporated where discrepancies were discovered.

In the event that an entity refuses to provide information required under the Law on State Statistics, the Minstat may require the entity to appear before a court and the court may impose a penalty. Court action is, however, used as a last resort and exercised in relatively few instances. Such cases have received publicity that is favorable to the Minstat and this appears likely to have had a deterrent effect on others who may contemplate refusal to comply with the Law on State Statistics.

The Minstat, therefore, has very strong powers to collect information for statistical purposes and this is reflected in very high response rates and, presumably, in accurate responses in the various questionnaires. The Minstat does not appear to have used other approaches to encourage response, such as the provision of brochures explaining the uses and importance of specific fields of statistics and the supply of summary data, free of charge, to respondents.

The Minstat may wish to consider supplementary approaches of these kinds as means of maintaining high levels of response.

In order to avoid nonresponses, all households are given clear instructions on how to provide price information. 


\section{$0.2 \quad$ Resources}

\subsubsection{Staff, facilities, computing resources, and financing are commensurate with statistical programs}

The Minstat has about 2,200 staff of which about 360 are located in headquarters in Minsk. About 90 percent of the staff is female. The overall staffing levels for the Minstat are regarded by senior management as adequate and staff turnover is not regarded as a significant problem; in fact the overall staff situation appears to be relatively stable. Retirement age is normally 55 years for women, but some retirees are re-appointed as temporary employees, in some cases temporarily replacing a staff member who is absent on maternity leave. The Minstat pays particular attention to ensuring that there are sufficient staff members to effectively carry out its various operations, while allowing for annual leave, maternity leave and other staff entitlements. There are some measures in place to encourage the retention of experienced staff. However, there are constraints on promotion and merit increases within the civil service system.

Number of staff working on prices appears adequate.

The Minstat's Department of Price Statistics

\begin{tabular}{lccccc}
\hline Number of Units & $\begin{array}{c}\text { Geographic } \\
\text { Breakdown }\end{array}$ & Number of Staff & CPI & PPI & $\begin{array}{c}\text { Head of } \\
\text { Prices }\end{array}$ \\
\hline Minsk & Republic level & 17 & 10 & 6 & 1 \\
Regions (6) & Regional level & $8-10$ & $\begin{array}{l}\text { Not separately assigned for CPI } \\
\text { and PPI }\end{array}$ \\
$\begin{array}{l}\text { Capital and } \\
\text { four districts }\end{array}$ & District level & 118 & -- & -- & - \\
Total & & 235 & & & - \\
\hline
\end{tabular}

The Republic of Belarus is geographically divided into six regions and Minsk City. The statistical survey for prices is arranged in 31 cities and towns of the country, including Minsk City, all regional centers, and four district centers in each region. At the regional level, work is done on both the CPI and PPI. At the republic level, there are ten specialists who work on the CPI, all of whom are university graduates.

Plans for prices expansion are gradual, thus, there are no needs for increases in staff and resources. The Minstat's salary levels are adequate for the nature of work, and are competitive with the private sector for comparable jobs and positions.

Computing needs and technology appear adequate. In April 2003, software was developed to estimate core inflation. The CPI data are saved on two computers plus on a floppy disk that are all housed in the Minstat. 
There are no provisions of emergency back-up systems for retrieval of CPI statistical series and their updates in the event of natural disasters, accidents, and other unusual events.

\subsubsection{Measures to ensure efficient use of resources are implemented}

Resources within the Minstat are allocated in accordance with the statistical work plan that is developed each year. The Minstat arranges for statistical inquiries to be conducted in accordance with the statistical work plan for the Minstat. The statistical work plan is prepared in consultation with ministries and other administrative bodies. This instrument is used by the Minstat for coordinating and approving statistical plans.

The statistical work plan is developed in an iterative way, starting with submissions from the heads of each department. The Department of Planning and Statistical Monitoring in the Minstat then drafts the entire work plan for consideration and approval by the Board of Management. The statistical work plan is approved in August of each year and covers the following five years. It includes details of plans to be achieved in each department of the Minstat, and target dates for various stages of development. Each department presents information on progress and achievements at annual meetings of the Board of Management.

Article 6 provides that the State statistical authorities are financed from state budget funds in accordance with the statistical work plan that is approved by the Council of Ministers of the Republic of Belarus. Additional statistical work may be carried out through supplementary financing from the state budget or funds provided by those requesting this work. The work plan sets out all statistical activities to be undertaken by the Minstat during the course of the plan, including target dates for completion of specific tasks. It is the responsibility of each department's head to ensure that their components of the work plan are completed satisfactorily. The statistical work plan is reviewed annually by the Board of Management of the Minstat. There is a certain amount of flexibility to incorporate any important new statistical activity between annual reviews where a major new statistical requirement has been articulated by the government.

Under Article 12 of the Law on State Statistics, State statistical authorities are required to "use international concepts, classifications, and methods in compiling statistics as the basis for ensuring the harmony and effectiveness of the statistical system of the Republic of Belarus on all official levels."

On an annual basis, a report on the specialists' performance is prepared by the head of the DPS for the Minstat. If a specialist work performance is inadequate, that specialist is terminated. Employment contracts for the Minstat staff are renewed every one to three years.

Efficiencies are sought through periodic reviews of work processes. Consistent concepts, classification, and other methodologies across categories are encouraged. The surveys are conducted and the source data are collected at the district level, then the source data are 
reviewed and collated at the regional level. The CPI data are then transmitted through dedicated lines to the Minstat.

The Minstat sends representatives to CIS meetings on statistics to discuss common problems and to get information on methodologies and ways of improving efficiency.

\section{$0.3 \quad$ Relevance}

\subsubsection{The relevance and practical utility of existing statistics in meeting users' needs are monitored}

Apart from the Inter-Agency Council for State Statistics, which focuses on methodological issues, there is no committee to provide advice about new and emerging data needs. The mission considers that the Minstat should examine the desirability of establishing a more broadly based user committee to provide it with advice on statistical policy, methodology, and priority issues.

Feedback from users on the quality standards of the CPI statistics is not solicited. There are no initiatives or projects in place to facilitate feedback from users of price statistics. The Research Institute of Economics solicits user feedback on data quality from business managers. However, the institute's idea of user feedback on data quality was conveyed to the Inter-Agency Council for State Statistics, but due to lack of resources, the project was put on hold.

The relevance and practical utility of the CPI data in meeting user needs are not assessed in any systematic way. The Minstat has not conducted any user surveys in the field of prices statistics and does not have any mechanism in place to systematically monitor user feedback on these statistics.

Data users are kept informed on prices statistics through the National Economic Gazette that is published twice per week. This newspaper publishes the CPI index on a monthly basis. Users' feedbacks are solicited and answers to users' questions on the CPI are published in this newspaper.

\subsection{Other quality management}

\subsubsection{Processes are in place to focus on quality}

Each year the Minstat performs tasks aimed at improving the current state statistical reports. The Minstat provides instructions on filling out these reports by taking into account the suggestions made by other ministries and departments. The drafts of reports and instructions 
are worked out jointly by the branch departments and the Department of Statistical Planning and Organization of Statistical Survey. These drafts of reports and instructions are then considered by the Scientific-Methodological Council of the Minstat that is headed by the first deputy minister, and then approved by the Minstat's Board of Management.

Each year, regional and district staff who work on the CPI participate in statistical seminars organized by the Minstat. The State University usually arranges a seminar for the Association of Statisticians of the Republic of Belarus that is headed by the Director of the Statistical Research Institute.

New studies are undertaken with the Federal Service of State Statistics of the Russian Federation. International comparisons are conducted to share views and new statistical ideas.

Source data are routinely checked and verified. Usually, specialists for the Minstat visit the regional offices to check and to verify (a) if prices are collected correctly, (b) if acceptable goods are selected for the CPI, and (c) if goods specification are detailed enough to allow for substitution.

In 2003, for two and a half months, the Committee of State Control performed an evaluation of data quality for the CPI. The committee's main task was to determine the statistical methodology used to estimate the CPI.

\subsubsection{Processes are in place to monitor the quality of the statistical program}

The Minstat's Department of Statistical Planning coordinates all work associated with the improvement and maintenance of statistical quality. The information on such issues is considered by the Board of Management. All statistical questionnaires are sent to the Department of Statistical Planning for review. Then, the questionnaires are considered by the Scientific-Methodological Council of the Minstat and approved by the Minstat's Board of Management.

The functions of the Board of Management of the Minstat include providing a clear focus on quality through close attention to methodological issues. This is, in turn, conveyed by management to staff throughout the organization. Each staff member is given a copy of a Duty Manual that, inter alia, reinforces the importance of high standards of work and the need to produce high standard statistics. In addition, staff members, as civil servants, are made aware of their responsibilities under the Law on the Civil Service, which includes references to the requirement for work of a high standard.

According to Article 3 of the Law on State Statistics, "Basic Tasks and Principles of State Statistics that is publicly available," states that the basic principles of state statistics are: (a) objectivity and reliability of statistical information; (b) stability and comparability of statistical data; and (c) accessibility and openness of statistical information within the bounds set by the legislation of the Republic of Belarus. 
Reviews are undertaken of all unusual movements in the price data received at the Minstat, and are traced back to the reporter, if necessary. The CPI data are disseminated twelve days after the reference period. At the district level, specialists have twenty days for collection and revision. Data are then sent to the regional offices that have five days to review the data before they are sent to the Minstat headquarters.

CPI data are final when documented by the Minstat.

\subsubsection{Processes are in place to deal with quality considerations in planning the statistical program}

There are no trade-offs between timeliness and quality. The annual plan ensures that all deadlines are met, and quality price statistics are compiled and disseminated.

\section{Assurances of integrity}

\subsection{Professionalism}

\subsubsection{Statistics are produced on an impartial basis}

Article 4 of the Law on State Statistics provides that the central statistical authority is subordinate to the Council of Ministers and shall act on the basis of the regulations approved by the Council of the Republic of Belarus. The regulations are prepared by the Minstat.

Article 10 provides that interference by any government authorities, officials, and other persons in the activity of the state statistical authorities shall not be permitted, and the mission was informed that there has never been any question of interference or attempted interference with the professional independence of the Minstat.

The appointment and termination of the minister are determined by the government. Upon election of the president a new government is formed. The present Minister of Statistics was appointed in 1998. The Minstat is contemplating proposing a change from a ministry to a National Statistical Committee, to help reinforce the notion of the independence of the chief statistician, making decisions based purely on statistical considerations and free from political interference.

Recruitment and promotion of specialists in the Minstat are based on the specialists' expertise in statistics. Specialists are usually recruited from the faculty of the department of statistics at the Belarusian State Economic University. The Minstat encourages research and analysis by specialists to maintain the Minstat's reputation for professionalism.

Professionalism is also promoted through the encouragement of staff participation in training courses, workshops and seminars, to ensure awareness and understanding of statistical standards and good statistical practices. 
The Minstat provides on-the-job training in prices at the regional and district levels. However, according to the Minstat, they do not have the opportunity to send their specialists in prices methodology and compilation methods to seminars and workshops arranged by the IMF Institute. The Minstat houses a statistical library where specialists can have easy access to professional literature.

The Minstat encourages specialist's research and analysis to maintain the Minstat's reputation for professionalism.

Under the auspices of the Organization for Economic Co-operation and Development (OECD), joint meetings with the Russian Federation, Mongolia, and other CIS countries are held once per year on the issues of international comparisons. International comparisons for price statistics are maintained in the majority of CIS countries. These meetings are attended by the heads of prices departments where discussions on CPI methodological compilations are conducted.

\subsubsection{Choices of sources and statistical techniques as well as decisions about dissemination are informed solely by statistical considerations}

The sources and methods for compiling price statistics and component statistics are fully under the control of the Minstat, and concepts and standards follow international standards to a large extent. Appropriate data sources are used throughout the compilation of the CPI. There appears not to have been any outside interference or attempted interference in matters of sources, methods, and dissemination.

Interference by any government authorities, officials, and other persons in the activity of the state statistical authorities is not permitted. There have been no known cases of interference or attempted interference.

Article 10 of the Law of the Republic of Belarus on State Statistics provides guarantees of independence in the selection of the methodology, data sources, content, and format of the data disseminated by the Minstat. According to the Minstat, there is no external interference in the conduct of its work. Article 3 of the Law on State Statistics reinforces this by stating that one of the basic principles of state statistics is objectivity and reliability of statistical information.

\subsubsection{The appropriate statistical entity is entitled to comment on erroneous interpretation and misuse of statistics}

Article 10 of the Law of the Republic of Belarus on State Statistics, "the Rights of State Statistical Authorities," states, among other things that the Minstat has the right to comment on the incorrect utilization and incorrect interpretation of statistical data. In cases where there are erroneous interpretations of the statistics, the Minstat will provide clarifications in the mass media (for example, publications in the National Economic Gazette). The Minstat 
monitors all newspapers for erroneous interpretation of the CPI and provides timely responses.

\subsection{Transparency}

\subsubsection{The terms and conditions under which statistics are collected, processed, and disseminated are available to the public}

The Minstat's web site at http://president.gov.by/Minstat/en/about/law.htm provides the Law of the Republic of Belarus on State Statistics. The terms and conditions under which official statistics are collected, compiled and disseminated are provided. These terms and conditions refer to the obligation to compile and disseminate price statistics, the confidentiality of the data reported, and other key features such as the Minstat's rights.

All statistical publications identify where more information about the Minstat and its prices statistics can be found.

\subsubsection{Internal governmental access to statistics prior to their release is publicly identified}

Metadata for prices posted on the Minstat's web site at http://president.gov.by/The Minstat/en/main.html clearly states that there is no internal governmental access to statistics prior to their release to the public.

\subsubsection{Products of statistical agencies/units are clearly identified as such}

Products of the Minstat are clearly identified through the use of the Ministry's name and logo on the web site and in publications. In the case of joint publications, the part attributable to the Minstat is clearly identified. The Minstat requests acknowledgement when its prices statistics are used for reproduction in other agencies or ministries publications.

\subsubsection{Advanced notice is given of major changes in methodology, source data, and statistical techniques}

The Minstat does not give advance notice to the public in statistical publications when major changes are introduced in methodology, sources, and statistical techniques for compilation of prices statistics. This mission was informed that prior to 2003, advance notice of planned changes, in summary form, was given to the public in the National Register of Legal Acts. However, this practice has now been discontinued. Users can obtain information on the changes in methodology, sources, and statistical techniques for compilation of prices statistics from the reference data base of regulative legal information maintained by the National Center of Legal Acts. 


\subsection{Ethical standards}

\subsubsection{Guidelines for staff behavior are in place and are well known to the staff}

Articles 13 and 15 of the Law of the Republic of Belarus on State Statistics provide guidelines on correct behavior when the Minstat or its staff is confronted with potential conflict of interest situations.

Article 13, "Obligations of Ministries and Other Central Administrative," stipulates that authorities that maintain state statistics are required to preserve state and commercial secrecy.

Article 15, "Liability for Violations Committed while Using Statistical Data," states that employees of state statistical authorities, ministries, and other central administrative authorities who maintain state statistics shall bear liability in accordance with the legislation of the Republic of Belarus for violating the requirements of this Law concerning the collection and use of statistical data and for concealing and distorting them.

Requirements regarding staff behavior are notified in the Duty Manual, which is provided to each staff member. The Law on civil service also provides guidelines about staff behavior. This Law was recently amended and training courses were arranged to inform staff about their responsibilities.

All new staff are required to sign an employment contract that outlines the ethical standards, and are reminded annually of these standards.

The Law on Civil Service requires civil servants to observe culture of communication and other norms of business ethics, not allow actions that negatively affect civil service, maintain confidentiality about work activities, and observe internal regulations of work procedures, especially with those related to confidential information. It provides guidelines about staff behavior, including the need to ensure the preservation of the confidentiality of data for individual entities. This Law was recently amended and training courses were arranged to inform staff about their responsibilities.

\section{Methodological soundness}

\subsection{Concepts and definitions}

\subsubsection{The overall structure in terms of concepts and definitions follows internationally accepted standards, guidelines, or good practices}

The concepts and definitions of the national CPI generally follow the recommendations of the System of National Accounts 1993 (1993 SNA). The methodology for compiling the CPI is described in detail in the publication Methodological Guideline in Statistics (2003). 
Expenditure weights are estimated using the HIES as the primary data source. The concepts and definitions used for measuring household expenditure is the HIES that follows 1993 SNA guidelines. The COICOP is used to classify goods and services included in the CPI.

There are no expenditure estimates either for household consumption of housing services from own production (owners' inputted rents, see also 2.2.1) or residential capital formation. Weights are not calculated, but are believed to be relatively insignificant. Nevertheless, residential ownerships are increasing and weights should be calculated.

\subsection{Scope}

\subsubsection{The scope is broadly consistent with internationally accepted standards, guidelines, or good practices}

Expenditure aggregate for households of all sizes are included in the CPI; however, only urban households are included in the CPI index weight. Rural households are not representative of the economy of the Republic of Belarus since the majority of the population resides in urban areas. Prices are collected from 31 cities and towns that comprise 68 percent of the total population of the Republic of Belarus, and 74 percent of all urban population. Many households with high income tend not to participate in the expenditure survey that is used to weight the CPI. However, macro level mathematical adjustments are conducted to make allowances for these households' exclusions.

Households whose major activity involves an unincorporated business activity are included in the CPI, but only data on household purchases and not their own-account consumption are included. Sales of illegal market goods and services such as prostitution and drugs are excluded.

Imputed rents for owner-occupied housings are excluded. According to the DPS, homeowners who live in their house and do not rent their house, do not provide information on imputed rents needed for the expenditure survey. Rents are included in the CPI, and these rental rates are the same for both the owners and lessees over a long period of time due to the structure of the Republic of Belarus's economy. According to the Inter-Secretariat Working Group on Price Statistics (IWGPS), subsidized and controlled prices in the actual rent series should not be used in calculating the owner's equivalent rent series. Nevertheless, imputed rents are missing components that should be included in the CPI series that is needed particularly for the deflator of dwelling activities of the GDP estimates. 


\subsection{Classification/sectorization}

\subsubsection{Classification/sectorization systems used are broadly consistent with internationally accepted standards, guidelines, or good practices}

The classification and sectorization used in the compilation of the CPI are in broad conformity with internationally accepted systems. COICOP guidelines are used to classify consumption activities.

\subsection{Basis for recording}

\subsubsection{Market prices are used to value flows and stocks}

Generally, market prices are used to value flows and stocks; however, there is some level of administrative price controls. Consumption expenditure in the HIES (the weights of the CPI) is valued at purchasers' prices, which include trade and transportation margins and applicable taxes less subsidies on products. Household residential capital formation is not included in the CPI.

All product specifications are carefully designed at the regional level with guidance provided by specialists in the Minstat in Minsk. Price determining characteristics generally consider size, color, brand, and quality.

\subsubsection{Recording is done on an accrual basis}

The prices of goods and services are recorded in the period they are purchased. The CPI is collected between the tenth and thirtieth of the month. The prices of volatile goods, such as bread, fruits, and vegetables are collected frequently, usually two to three times per month.

\subsubsection{Grossing/netting procedures are broadly consistent with internationally accepted standards, guidelines, or good practices}

The CPI does not cover net purchases of existing goods, such as used cars, owner-occupied housing or other durable consumption goods with a secondary market that are defined as acquisition less disposal of such goods. Third party liability car insurance, the only insurance offered in the Republic of Belarus, is not included in the CPI so there are no issues relating to netting claims from premiums paid. 


\section{Accuracy and reliability}

\subsection{Source data}

\subsubsection{Source data are obtained from comprehensive data collection programs that take into account country-specific conditions}

Data sources are kept under continuous review to ensure that the data collection program is comprehensive. Specialists located at the regional and district levels check the places of purchases, public and private enterprises, and informal markets to ensure that data are correct.

In order to estimate the CPI, the Minstat selects over 377 goods and services that characterize the structure of consumer expenditure of the population. Registration of the prices is carried out in 31 cities and towns of the Republic of Belarus, in public and private retail shops, and in urban and informal market places.

Information from other available sources is used to supplement the core compilation. These sources include the (a) Capital Construction, Fees and Rental Commercial Services Department, (b) Statistical Trade and Services Department, (c) Social Statistics Department, (d) Retail, Wholesale Department, (e) Trade and Payment Services to the Population Department, and (f) Population Department.

Sources for CPI Weights: The HIES is conducted as a regular sample survey covering approximately 6,000 households. The sample selection is based on the 1999 population census with regular updating for population changes (births, deaths, and migration) based on administrative records. Adjustments are also made, in the latter stages of the census cycle, with reference to electoral roll data. The sample is representative of large cities, smaller cities within oblasts, towns, and villages.

The sample of households is selected so that each household has an equal chance of selection. Response is voluntary, but a response rate of 86 percent is achieved. Where a household drops out of the survey, mathematical procedures are applied to compensate for missing data. Households that change addresses are not followed to the new address unless they move within the same city and are easy to locate. Otherwise, such households are treated as nonresponse cases and their loss from the sample is compensated for by reweighting.

Collective households (such as elderly and nursing homes, student hostels, hotels, soldiers' barracks, hospitals, sanatoria, and prisons) are excluded from the HIES.

Corrections for nonresponse bias are made with reference to basic data collected for each household (including refusals) on characteristics such as place of residence, number in household, number of children under 18 years, number of elderly persons, and type of housing. 
The sampled families are surveyed during a 12-month period, and each household is visited 17 times by an interviewer. Two types of information are collected.

- A diary is kept by each household to record daily expenditure for a 14-day period, including detailed descriptions of items, place of purchase and value, as well as daily consumption of food produced on the individual land plot (production for own consumption) or received as a gift. Sample families are equally distributed in to rotation groups throughout the quarter.

- $\quad$ An interview is used to obtain data on major household expenditures and incomes during the last quarter. This information is used to calculate annual expenditures and incomes.

Data produced from the HIES and used by the Consumer Prices Department include average monthly expenditure per family on 878 codes of the consumer goods and services based on COICOP. Food expenditure items are further subdivided into 285 items.

Sources for CPI Prices: Coverage of the CPI is comprehensive. The enterprises from which prices are collected are selected by purposive sample based on the kinds of products sold. Most prices are collected by personal visits to the enterprises. Interviewers are required to select and precisely specify the most popular variety, for which prices will then be collected on a continuing basis. Primarily large supermarkets and retailers are selected, but medium and large market places are also included. No street vendors are included. At the district level, three price quotes are selected, at the regional level, five price quotes are selected, and, in Minsk city, ten price quotes are selected (each region including Minsk city have administrative district offices who collects the price information).

Places of recording change; in the sample however, the cities included do not change. Prices for 377 goods and services are collected monthly for 31 cities of the Republic of Belarus. The CPI includes all major groups of goods and services covering 41,000 prices. However, the CPI does not include owner-occupied dwellings, illegally marketed goods, and secondhand durable goods.

The sample for the CPI is composed of 4,385 outlets. There are 1,043 outlets for food, 1,845 outlets for nonfood products, and 1,497 outlets for services. The sample information maintained by the Minstat contains the name of the outlets, the address, the types of products sold, and whether the outlet is public or private.

Ad hoc surveys are conducted to identify new products and provide source data for weights and prices. First, the DPS determines what good to investigate, then, the HIES surveys households to determine if adequate amounts are being consumed for that particular good, and if so, interviews are conducted at the regional and district levels to collect the price for this good. 
Unfortunately there are no periodic meetings held with consumer groups and the business community to identify new developments that should be taken into account in the CPI compilation system. This problem highlights the need for a users' group.

\subsubsection{Source data reasonably approximate the definitions, scope, classifications, valuation,} and time of recording required

The Minstat's price data are consistent with the definitions, scope, classifications, and time of recording, reference periods, and valuation of CPI estimates.

The CPI price sample is representative of monetary transactions in urban areas for the goods and services used by households for consumption, with the exception of used goods.

\subsubsection{Source data are timely}

HIES' data are timely to allow for the compilation of the CPI data. Four interviews are preceded by a baseline interview for the expenditure survey. In addition, between each pair of interviews, the households are asked to keep a diary of current expenses for a period of two weeks. A new sample is selected annually. Thus, the weights for the CPI are annually updated. Regional specialists are guided by the annual plan so that prices for the CPI are collected in a timely manner. The CPI sample is also timely.

\subsection{Assessment of source data}

3.2.1 Source data - including censuses, sample surveys and administrative records-are routinely assessed, for example, for coverage, sample error, response error, and nonsampling error; the results of the assessments are monitored and made available to guide statistical processes

The sampling errors for each survey conducted are monitored on a monthly basis. Information on weights, price relatives, misclassifications, and outliers are routinely checked. Problems of non response are uncommon due to the established relationships between the interviewers and the enterprises. Corrections are done to account for any misclassifications. If there were a mistake with last month's price, the specialist would be alerted and corrections to previous data would be done.

Possible response error could occur during the collection of the household expenditure survey. For example, households appear to systematically underreport expenditures on commodity groups such as tobacco and alcoholic beverages. For that reason, the DPS supplements the data source with data from the Statistical Trade and Services Department. Data for communal services are supplemented by the Capital Construction Department. Data for cultural services, movies, and theaters are supplemented by the Social Statistics Department. 
Unusually large movements in prices are traced back to the retail enterprise if warranted and are verified. Apart from this kind of verification, post-enumeration checks are not made. Pilot testing is done to analyze the effects of changes in the survey questionnaires. Comments and recommendations are solicited from the enterprises in order to design a better enterprise survey.

The accuracy of administrative data received from other ministries, trade associations, regulatory authorities are not routinely assessed. According to the Minstat, these data are obtained on a regular basis, and therefore are not checked. Even though these data sources are approved for dissemination to the Minstat and are signed by officials of these administrations, periodic checks by the Minstat are required.

\subsection{Statistical techniques}

\subsubsection{Data compilation employs sound statistical techniques to deal with data sources}

The CPI is collected and tabulated first at the district level, second, at the regional level, then in the Minstat. Prices are first collected and tabulated at the district level and then sent to the regional offices. Two data sets or 12 sets of data are sent by the regional office, to the Minstat. One data set contains the capital of regions, and the other data sets contain aggregated data on four cities. At the regional level, price relatives are aggregated at the elementary levels for the 377 items in each of the six regions plus Minsk. Upon receipt in the Minstat, all data sets are combined, weighted, and aggregated into the national index.

Adjustments to unit records are made only when clearly warranted and can be identified in the price tabulations. When outliers are identified, data are first verified from the datasets in the Minstat, then the regional and district offices are contacted if adjustments are needed.

Procedures for imputation and adjustment for nonresponse are soundly based. There are no failures to obtain the required information in a timely manner from all enterprises selected in the sample.

Prices for temporarily missing products are imputed based on the change in price of similar products using the matched samples technique. Prices for seasonal products, such as fruits and vegetables, are also imputed. Products that become permanently unavailable are replaced in the sample. The design of the product specification allows for such replacements. Quality adjustments for products are conducted, usually using an explicit quality adjustment. Since specialists are privy to input costs, as mandated by the Statistical Law, they are able to estimate the value of the quality change. Thus, there is no need for implicit quality adjustment methods such as over pricing.

New products are introduced into the sample as they gain market share. The DPS coordinates with the HIES to determine when a new product gain ample market share and when to introduce the product into the CPI. 
The CPI in the Republic of Belarus is compiled in two stages. The first stage is performed in the regional office where price ratios are aggregated at the elementary levels for one month, price change of each of the 377 items groups in each of the six regions plus Minsk. The second stage is performed in the Minstat, using a modified Laspeyres formula, where the 377 short-term price indices are aggregated into the national index.

\subsubsection{Other statistical procedures (for example, data adjustments and transformations, and statistical analysis) employ sound statistical techniques}

The HIES, as defined in the $1993 S N A$, is used to establish weights. The weights are annually revised and are introduced into the index in May of each year. According to the InterSecretariat Working Group on Price Statistics, countries in which there are periods of high inflation, as in the case of the Republic of Belarus, multiple year weights should be calculated instead. Multiple year weights can be calculated either by averaging the value shares or averaging actual value levels. Averaging value levels will give more importance to the most recent year of data in the index base period. Another option is to uprate the value for each year to a common period and then compute a simple arithmetic average of adjusted yearly data.

According to the DPS, the share of parallel markets or underground economies is small in the Republic of Belarus; therefore, expenditure weights are not estimated.

There are no distinctions in prices if the consumer chooses to pay by credit or by cash. The values recorded for goods and services represent the economic cost to the consumer at the time the good or service is purchased regardless of method for payment.

Goods and services produced for own final consumption are not included in the CPI.

At the elementary level, an arithmetic mean or the ratio of average prices is used to calculate the index. Short-term price change is calculated base on previous month $=100$. Long-term price change is calculated as December of the previous year $=100$, and historical chained index with December $1990=100$.

The method used to aggregate the elementary indices to higher levels is a modified Laspeyres formula. The present CPI weights refer to the year 2002. The weights are fixed at the item level, and are adjusted for price change to align them with the appropriate price reference period. When new weights are introduced, the new index is linked to the old index, and an annual overlap period is used to calculate linking factors. One and a half to two months are needed to link the old index to the new index. 


\section{$3.4 \quad$ Assessment and validation of intermediate data and statistical outputs}

\subsubsection{Intermediate results are validated against other information where applicable}

The CPI is compared with the PPI and export and import price indices from the Foreign Trade Department.

Implicit deflators in the national accounts are available for the part of the economy covered by the regular CPI compilation. However, using micro surveys, an index of communication services for legal entities that are not covered in regular CPI compilation, is estimated by the DPS for national accounts. Cargo and transportation data are also compiled by the DPS for the Transportation and Communication Statistics Department, and are not included in the CPI.

\subsubsection{Statistical discrepancies in intermediate data are assessed and investigated}

Any unusual movements such as outliers in item indices are verified and traced back to the reporting outlet if necessary.

\subsubsection{Statistical discrepancies and other potential indicators of problems in statistical outputs are investigated}

Discrepancies arising from inconsistent imputation for missing data, seasonal goods, and quality adjusted goods are routinely assessed. Unfortunately, there are no ranges of control edits supported by computer programs that can be used to assess and validate the data. All verifications and assessments are done manually. Manual verifications may lead to nonsampling and nonobservation errors.

\subsection{Revision studies}

\subsubsection{Studies and analyses of revisions are carried out routinely and used internally to inform statistical processes (see also 4.3.3)}

CPI data are not revised once published. However, weights are routinely analyzed to determine the effects of sampling bias in the index. The items in the CPI basket and source data are analyzed to determine nonsampling errors. Findings from these revision studies are shared with the specialists at the regional and district levels, with the hopes that future errors can be avoided.

Adequate documentation on these revision studies is well maintained and includes methods used to incorporate new data sources, and the way data are adjusted. All proposals for weight revisions must be approved by the Scientific Methodological Council of the Minstat. Final approval is given by the Order of the Minister with registration in National Register of Legal Act of the Republic of Belarus. This order is published in the Official Bulletin of Legal Acts. 
According to the Law on Indexing of Population Income, information concerning any revisions in the CPI must be published since the population income is indexed to the CPI.

\section{Serviceability}

\subsection{Periodicity and timeliness}

\subsubsection{Periodicity follows dissemination standards}

The periodicity of the statistics follows the SDDS requirements. The CPI is compiled monthly.

\subsubsection{Timeliness follows dissemination standards}

The monthly estimates are disseminated within one month after the end of the reference month. Summary CPI statistics are disseminated 12 days after the end of the reference period, while more detailed CPI data are disseminated 21 days after the end of the reference period, and accordingly exceeds SDDS requirements.

\subsection{Consistency}

\subsubsection{Statistics are consistent within the dataset}

There are no consistency issues as the CPI is not calculated for regions or population centers within the Republic of Belarus, nor is it calculated for a particular subgroup.

\subsubsection{Statistics are consistent or reconcilable over a reasonable period of time}

Time series data are available for at least five years. Historical time-series data are available for December $1990=100$. In July 1993, the IMF Technical Assistance mission recommended that the new CPI and historical time-series should be officially published so that other government agencies, businesses, and international organizations can take advantage of the State Statistical Committee's most reliable broad-based measure of the general level of inflation for the Republic of Belarus. A historical time-series with index reference period of December $1990=100$ has been infrequently published. This historical time-series is annually published only in the National Economic Gazette, and not in any other official statistical publications.

The DPS hyperlinked the CPI historical time-series to the Minstat's web site during the mission. The availability of historical time-series is a requirement of the SDDS. 


\subsubsection{Statistics are consistent or reconcilable with those obtained through other data sources and/or statistical frameworks}

CPI data are largely consistent with the PPI and national accounts statistics.

\subsection{Revision policy and practice}

\subsubsection{Revisions follow a regular and transparent schedule}

CPI data are not revised once published. However, the CPI weights are updated annually. The new weights are normally introduced with data published in June.

The public is aware of the annual weight updating of the CPI.

\subsubsection{Preliminary and/or revised data are clearly identified}

CPI data are final and are not subject to revisions.

\subsubsection{Studies and analyses of revisions are made public (see also 3.5.1)}

The impact of annual weight updating studies is not disseminated in official statistical publications, but would be appropriate for the annual CPI statistical bulletins. Nevertheless, according to the Law on Indexing of Population Income, information on CPI must be published since the pension and public wage income is indexed to the CPI.

\section{Accessibility}

\subsection{Data accessibility}

\subsubsection{Statistics are presented in a way that facilitates proper interpretation and meaningful} comparisons (layout and clarity of text, tables, and charts)

CPI data are published in a clear manner. In certain publications, charts and tables are also disseminated with the data to facilitate analysis. Datasets are published in consolidated format, by food, nonfood, and services. Data for each category are further broken down by the types of food, nonfood, and services. In all statistical publications, the CPI data are published with the corresponding period of the previous year $=100$, previous month $=100$, and December of the previous year $=100$. CPI data for each year since 1992 to 2002 are published. Chain-linked historical time series data have been disseminated in the National Economic Gazette on an infrequent basis, but now are posted on the Minstat's web site.

The infrequent publication of long time series data of five years or greater, with a given reference base, does not meet international good practice for index publication. 
Relevant series are not disseminated in a seasonally adjusted form, and there are no plans to seasonally adjust the data.

\subsubsection{Dissemination media and format are adequate}

CPI data are disseminated in ways that facilitate redissemination in the media through official press releases and internet web site. The data are simultaneously disseminated to all interested parties through a monthly press release prepared by the Minstat, "Balta." Data are also simultaneously disseminated on the Minstat's internet web site http://president.gov.by/Minstat/main.html.

More comprehensive and/or detailed statistics are also disseminated. Requests for these types of data are usually completed in five days and longer if requests are labor intensive.

CPI data published with the corresponding period of the previous year $=100$, previous month $=100$, December of the previous year $=100$, and CPI data for each year since 1992 to 2002 and CPI in December $1990=100$, are published on the Minstat's web site.

\subsubsection{Statistics are released on a preannounced schedule}

An advance release calendar is posted on the Minstat's web site, http://president.gov.by/Minstat/main.html, with release dates for the upcoming three months.

CPI data are usually released punctually on the twelfth of the month. If the twelfth is not a working day, the CPI is released on the prior Friday before the twelfth.

\subsubsection{Statistics are made available to all users at the same time}

The CPI data are transmitted simultaneously to all users on the twelfth of the month, or the prior Friday before the twelfth of the month, usually through the press release.

\subsubsection{Statistics not routinely disseminated are made available upon request}

Detailed customized tabulation (detailed breakdowns) of CPI data is available upon request, in addition to the tables routinely disseminated. For specific purposes, customized tabulation of data that satisfy the Minstat's disclosure requirements are also available for a fee.

Data users are aware of the availability of additional statistics and of the procedures for obtaining them. These procedures are explicitly provided in statistical publications. 


\subsection{Metadata accessibility}

5.2.1 Documentation on concepts, scope, classifications, basis of recording, data sources, and statistical techniques is available, and differences from internationally accepted standards, guidelines, or good practices are annotated

Brief CPI methodologies are provided in the Statistical Yearbook of the Republic of Belarus, 2003, Consumer Price Indices, the Quarterly Statistical Bulletin, and in Price Indices for Consumer Goods and Services, and for Produced Industrial Goods. Very detailed methodological descriptions are provided in statistical publications, such as Methodological Guidelines and Methodological Guidelines on Statistics; however, these publications are not easily accessible to the public. Users can obtain methodological information in the reference database of the regulative-legal information.

There is no published information in official statistical publications on the survey sources, such as the response rates, survey monitoring, nonsampling errors, sample frame, sample design, estimation, and imputation techniques. However, references are made of the administrative data sources used.

The Republic of Belarus is expected to subscribe to the SDDS in the near future. However, while there are no SDDS summary methodologies on CPI at this time, there are CPI metadata in SDDS format that are posted on the Minstat's web site.

\subsubsection{Levels of detail are adapted to the needs of the intended audience}

There are no pamphlets, brochures, background papers, or working documents about the CPI and other prices statistics that are made available to the public on a frequent basis.

\subsection{Assistance to users}

\subsubsection{Contact points for each subject field are publicized}

A contact person with telephone, facsimile, email, and internet address is provided on the inside of most price statistics publications.

Assistance to users is monitored and reviewed periodically. According to the Minstat, when requests are made for CPI data, the General Department logs these requests with a number, and tracks when the request was made and implemented. Users, however, said that request for data are not met in a timely manner. 
5.3.2 Catalogs of publications, documents, and other services, including information on any changes, are widely available

The Minstat publishes a comprehensive print catalogue of all of its publications. This catalogue is annually updated. But, the prices of the statistical products and services are not disclosed due to the frequent changes in price. Prices are listed as contractual. 
Table 2. Republic of Belarus: Data Quality Assessment Framework (July 2003): Summary of Results for Price Statistics (Consumer Price Index)

(Compiling Agency:Minstat)

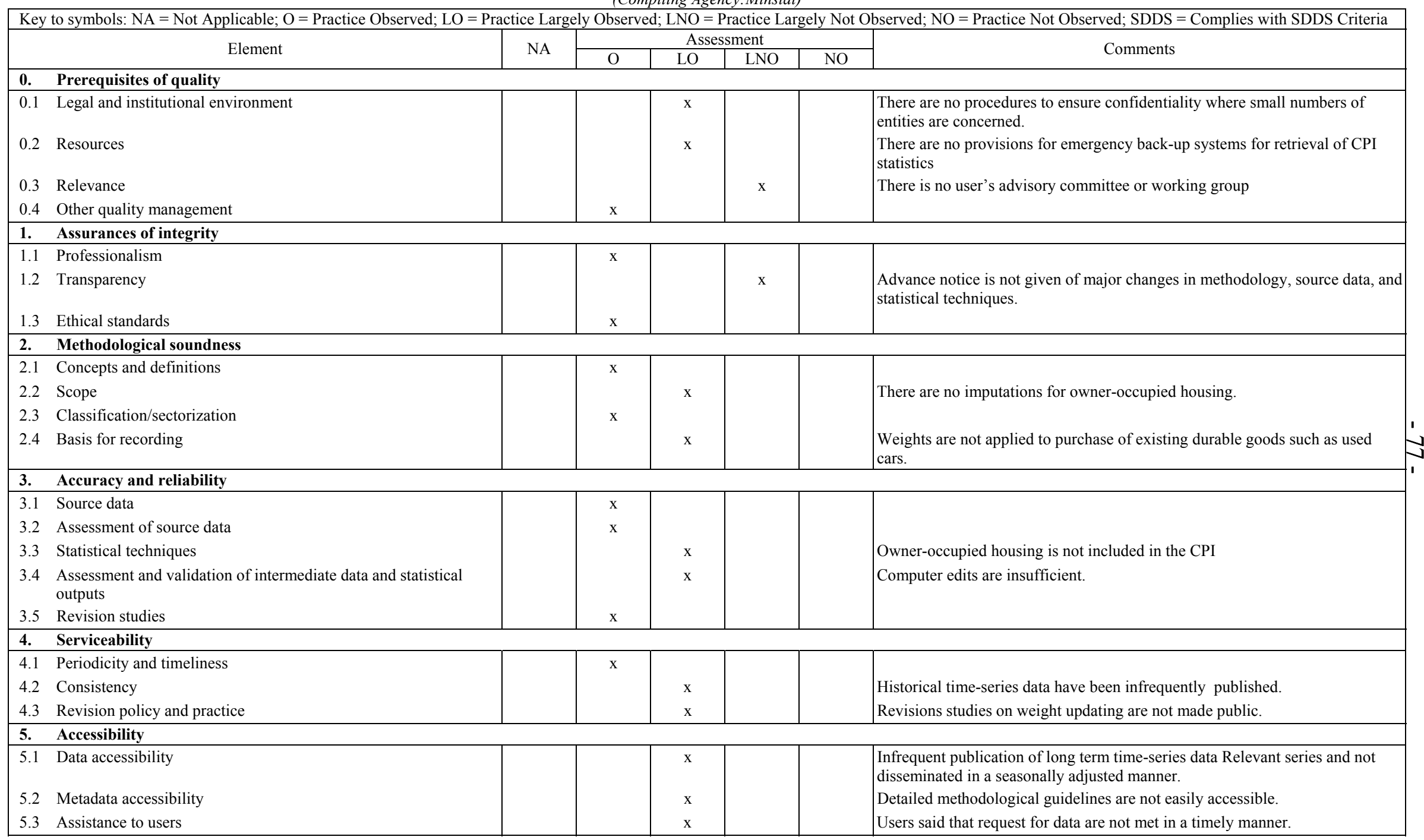

CInternational Monetary Fund. Not for Redistribution 


\section{Price Statistics (Producer Price Index)}

\section{Prerequisites of quality}

\section{$0.1 \quad$ Legal and institutional environment}

\subsubsection{The responsibility for collecting, processing, and disseminating the statistics is clearly specified}

The production of official statistics in the Republic of Belarus is the responsibility of the Ministry of Statistics and Analysis of the Republic of Belarus (Minstat). The Minstat operates under the Law of the Republic of Belarus on State Statistics (the Law on State Statistics), which was adopted by the House of Representatives on January 11, 1997, approved by the Council of the Republic on January 30, 1997, and signed by the President of the Republic of Belarus on February 17, 1997. The Law on State Statistics was developed in line with recommendations of Eurostat.

The Minstat is accountable to the Council of Ministers of the Republic of Belarus and operates under Belarusian legislation. It has its own settlement account and other accounts with banking institutions.

The State statistical system for the Republic of Belarus comprises the Minstat, and oblast (including City of Minsk), district and city agencies of statistics. The Minstat and its agencies in oblasts, cities and regions, and other organizations subordinated ${ }^{14}$ to the Minstat constitute a single system of State statistics for the Republic of Belarus.

The Minstat is headed by a Minister who is appointed under the Constitution by the President. The Minister is a member of the government and is empowered to issue directives and instructions that are binding on subordinate statistical bodies within the Minstat.

The Minstat has a Board of Management that comprises the minister (as chairman), his deputies, and other staff. The Board of Management considers and determines fundamental issues relating to the organization of statistical activities (for example, methodology, questionnaires, release practices, staff appointments and terminations, performance at regional levels, organization structure, statistical program priorities, and budgetary allocations). The Minister of Minstat, as a member of the Cabinet of Ministers, reports to the government concerning major decisions made by the Board.

\footnotetext{
${ }^{14}$ Subordinate organizations include main computing center, Statistical Research Institute Computing Centers of Oblast (City of Minsk) department of statistics.
} 
There is also an Inter-Agency Council for State Statistics, established under a government resolution, which makes proposals on methods and questionnaires, and considers proposals for the inclusion in the statistical work plan (discussed below). The Inter-Agency Council for State Statistics reviews proposals submitted to it, and makes recommendations that are forwarded to the Council of Ministers for decisions about financing.

The Inter-Agency Council for State Statistics comprises the Deputy Prime Minister of the Republic of Belarus (Chairman), the Minister of the Minstat, the Minister of Labor and Social Protection, the Minister of Justice, the Deputy Ministers of Industry, Finance, and Economy, and representatives of the Academy of Science and other bodies. The composition of the Council allows it to take direct account of user requirements to some extent, but it is not very broadly based in terms of membership compared with models in some countries. Due to its membership, it functions as an advisory body rather than an executive decision making body. The reports of the Council are publicly available documents.

Article 3 of the Law on State Statistics specifies the basic tasks of state statistics as:

- $\quad$ collecting, processing, compiling and analyzing economic and social statistics, using scientifically based statistical methodology; and

- disseminating statistical information to governmental authorities and other users.

The Minstat, its offices in the oblasts, cities, and rayons, and the other subordinate organizations constitute the uniform system of state statistical authorities of the Republic of Belarus. The Minstat is subordinate to the Council of Ministers of the Republic of Belarus. The Minstat acts on the basis of the provisions of the Minister of the Minstat, as approved by the Council of Ministers of the Republic of Belarus, and other regulatory acts.

Article 10 provides that State statistical authorities have the right to:

- receive statistical data, in the manner established by the central statistical authority, from legal entities, and entrepreneurs who have not formed a legal entity;

- $\quad$ verify the reliability of statistical data and, where distortions are found, to give mandatory instructions concerning their elimination and appropriate corrections in aggregated statistical data; and

- $\quad$ require entities to comply with the requirements of the Law, including entities that are not legally incorporated. 
Under Article 11, ministries and other central administrative authorities that produce state statistics shall have the right to:

- $\quad$ receive and use statistical data "in the manner specified by Articles 5, 8, and 9 of this Law"; and

- monitor the status of primary accounting and statistical reporting, and check the authenticity of statistical data reported.

Under Article 12, State statistical authorities are required to:

- $\quad$ organize state statistical observations and provide government authorities with reliable and objective statistical information on the socio-economic situation of the country;

- $\quad$ ensure the accessibility of summary statistical information for a wide range of users, and give necessary explanations and comments on the methodology of producing statistical data, including through the mass media; and

- $\quad$ ensure that the primary data collected by state statistical authorities are not subject to disclosure and are used exclusively for statistical purposes.

The Minstat is required to provide State bodies and other users with reliable and objective economic and social statistics, including national accounts statistics. It also provides explanations about methodologies for compiling data.

Section 34 of the Constitution of the Republic of Belarus provides that citizens have the right to receive information on the activities of State bodies, and those bodies shall provide citizens with an opportunity to obtain access to the materials pertaining to their rights and legitimate interests. This Section of the Constitution is endorsed by Article 12 of the Law on State Statistics. The extensive publication program of the Minstat is consistent with this provision in the Constitution.

Within the Minstat, the Department of Price Statistics (DPS) is responsible for the compilation of the Producer Price Index for the Republic of Belarus.

\subsubsection{Data sharing and coordination among data-producing agencies are adequate}

The Law on State Statistics provides for data sharing and coordination of statistical activities.

- $\quad$ Article 5 provides that ministries and other central administrative authorities shall compile state statistics in accordance with the forms and methodological instructions approved by the central statistical authority. 
- $\quad$ Article 7 provides that State statistical observations (including state administrative data, one-time assessments, censuses, and sample surveys) shall be carried out by state statistical authorities, ministries, and other central administrative authorities on the basis of the methodological instructions, programs, and forms of statistical reporting approved by the central statistical authority.

- $\quad$ Article 10 states that decisions of the state statistical authorities, within their competence, shall be mandatory for implementation by ministries, other central administrative authorities, local executive and administrative authorities, legal entities and other individual entrepreneurs.

- Article 13 requires ministries and other central administrative authorities that compile state statistics to:

- ensure the collection, processing, and reliability of statistical data in their areas of responsibility; and

○ supply to state statistical authorities, on their demand, statistical data specified by state statistical reporting.

The Department of Statistical Planning and Statistical Monitoring within the Minstat is responsible for ensuring effective coordination between the Minstat and the ministries with the primary responsibility for compiling the statistics and other data producing agencies.

\subsubsection{Individual reporters' data are to be kept confidential and used for statistical purposes only}

Article 9 provides that information containing state and commercial secrets shall not be subject to disclosure, and stipulates that statistical information shall be used for State and scientific purposes and for informing the public. This provides for the protection of the privacy of individual data submitted by, and in respect of, persons.

Article 15 specifies that employees of State statistical authorities, ministries, and other central administrative authorities who produce state statistics must not violate the requirements of the Law concerning the collection and use of statistical data and for concealing and distorting them. Employees of the Minstat are required to sign a contract at the commencement of employment that they will not divulge State secrets. This requirement is reinforced in a Duty Manual supplied to each staff member. All computers are password protected. The Minstat's officials informed the mission that there has been no instance where an employee has violated this requirement of the Law.

Article 12 further reinforces the requirement for confidentiality of individual data supplied. State statistical authorities are required to preserve state and commercial secrecy, and to ensure that primary data obtained from legal entities or physical persons are used exclusively for statistical purposes. Similarly, Article 13 requires that ministries and other central 
administrative authorities that produce state statistics shall preserve state and commercial secrecy. In addition, article 21 of the Law on Civil Service in the Republic of Belarus (law No. 204-3 of June 14, 2003) states, among the obligations of civil service, that civil servants must not disseminate state secrets entrusted to them, and the disclosure of state secrets could result in their dismissal of the civil service.

The mission discussed with senior officials from the Minstat the question of release of data where only a small number of entities are involved. The mission was informed that, where one or two nongovernment enterprises contribute to a statistical cell, the Minstat ensures that such data remains confidential, but that these rules are not applied where government enterprises are concerned. The mission considers that more comprehensive procedures are required to guide staff in ensuring that statistics released do not disclose information relating to an individual entity, either directly or by deduction. This is important in order to maintain public confidence in the Minstat.

The Minstat's officials indicated that there are situations where an entity may give written consent for the disclosure of information about the entity, but that the Minstat seeks to avoid too many such situations from a workload point of view. The mission observed, however, that it is not clear from the legislation that the Minstat has the authority to release individual data with the consent of the entity concerned. This is a legal right of statistical agencies in some other countries and the mission considers that the legislation in the Republic of Belarus should be clarified concerning this right, even though it is seldom exercised.

The Minstat should consider seeking an amendment to the Law on State Statistics enabling the Minstat to release data that would otherwise be confidential with the consent of the entity (entities) involved. This provision would need to be used very sparingly, but would allow publication of significant data where only one or two entities are involved; e.g., the production of a specific commodity by one or two producers.

All survey questionnaires state clearly, on the top of the front page, that all information collected by the Minstat will be kept confidential and used for statistical purposes only.

Officials of the Minstat assured the mission that there is adequate physical security for all premises, adequate physical protection of computing facilities, and various encoding procedures, all of which serve to assist in protecting the confidentiality of the data stored in the premises of the Minstat and guard against unlawful access to data.

The staff is sensitive to issues regarding data confidentiality and takes appropriate measures to ensure that respondents' information are guarded. All computers are password protected, and a local network is provided only for prices information.

Confidentiality agreements are signed by PPI specialists. PPI data are presented only in aggregated and consolidated manner for researchers and other persons requesting data. 


\subsubsection{Statistical reporting is ensured through legal mandate and/or measures to encourage response}

There is a clear legal mandate for collection of information for statistical purposes. Article 8 requires that all legal entities, and entrepreneurs who have not formed legal entities, shall submit statistical reports free of charge, observing the forms, deadlines, and addresses approved by the central statistical authority. Article 8 also provides that questionnaires and deadlines for statistical reporting by banks, free of charge, shall be approved by the central statistical authority as agreed with the National Bank of the Republic of Belarus (NBRB).

Under Article 14, officials and entrepreneurs carrying out their activity without forming a legal entity who evade the mandatory submission of statistical data to state statistical authorities and also to ministries and other central administrative authorities that produce state statistics, or submit them in a distorted form or in violation of the established schedules, are in breach of the legislation. In addition, damage caused as the result of the submission of distorted statistical data shall be subject to penalty under legislation of the Republic of Belarus.

The Minstat's employees are entitled to visit business entities in order to check the accuracy of the data reported in State statistical questionnaires. Such inspections are selectively undertaken by the Minstat, sometimes involving specialists of branch ministries. These measures result in a high level of cooperation and the collection of reliable data. In 2003, inspections on data accuracy were carried out at 3,700 business entities. Amendments were incorporated where discrepancies were discovered.

In the event that an entity refuses to provide information required under the Law on State Statistics, the Minstat may require the entity to appear before a court and the court may impose a penalty. Court action is, however, used as a last resort and exercised in relatively few instances. Such cases have received publicity that is favorable to the Minstat and this appears likely to have had a deterrent effect on others who may contemplate refusal to comply with the Law on State Statistics.

The Minstat, therefore, has very strong powers to collect information for statistical purposes and this is reflected in very high response rates and, presumably, in accurate responses in the various questionnaires. The Minstat does not appear to have used other approaches to encourage response, such as the provision of brochures explaining the uses and importance of specific fields of statistics and the supply of summary data, free of charge, to respondents.

The Minstat may wish to consider supplementary approaches of these kinds as means of maintaining high levels of response.

In order to avoid nonresponse, all enterprises are given clear instructions on how to provide price information. The methodological guidelines written in the statistical publications also provide instructions on how respondents should provide price information. Standing seminars are held at the regional and district levels to answer any questions posed by 
respondents. Standing seminar agendas or schedules are provided by the Department of Statistical Planning and Organization of Statistical Surveys.

\section{$0.2 \quad$ Resources}

\subsubsection{Staff, facilities, computing resources, and financing are commensurate with statistical programs}

The Minstat has about 2,200 staff of which about 360 are located in headquarters in Minsk. About 90 percent of the staff is female. The overall staffing levels for the Minstat are regarded by senior management as adequate and staff turnover is not regarded as a significant problem; in fact, the overall staff situation appears to be relatively stable. Retirement age is normally 55 years for women, but some retirees are re-appointed as temporary employees, in some cases temporarily replacing a staff member who is absent on maternity leave. The Minstat pays particular attention to ensuring that there are sufficient staff members to effectively carry out its various operations, while allowing for annual leave, maternity leave and other staff entitlements. There are some measures in place to encourage the retention of experienced staff. However, there are constraints on promotion and merit increases within the civil service system.

Number of staff working on prices appears adequate.

The Minstat's Department of Price Statistics

\begin{tabular}{|c|c|c|c|c|c|}
\hline Number of Units & $\begin{array}{l}\text { Geographic } \\
\text { Breakdown }\end{array}$ & Number of Staff & CPI & PPI & $\begin{array}{c}\text { Head of } \\
\text { Prices }\end{array}$ \\
\hline Minsk & Republic level & 17 & 10 & 6 & 1 \\
\hline Regions (6) & Regional level & $8-10$ & \multicolumn{3}{|c|}{$\begin{array}{c}\text { Not separately assigned for CPI } \\
\text { and PPI }\end{array}$} \\
\hline $\begin{array}{l}\text { Capital and four } \\
\text { districts }\end{array}$ & District level & 118 & -- & -- & -- \\
\hline Total & & 235 & & & \\
\hline
\end{tabular}

The Republic of Belarus is geographically divided into six regions and Minsk City. Statistical survey for prices is arranged in 31 cities and towns of the country including Minsk City, all regional centers, and four district centers in each region. At the regional level work is done on both the CPI and PPI. At the republic level, there are six specialists who work on the PPI, all of whom are university graduates.

Plans for prices expansion are gradual, thus there are no need for increases in staff and resources. The Minstat's salary levels are adequate for the nature of work, and are competitive with the private sector for comparable jobs and positions. 
Computing needs and technology appear adequate. In January 2003, software to estimate the PPI was updated.

There are no provisions of emergency back-up systems for retrieval of PPI statistical series and their updates in the event of natural disasters, accidents, and other unusual events.

\subsubsection{Measures to ensure efficient use of resources are implemented}

Resources within the Minstat are allocated in accordance with the statistical work plan that is developed each year. The Minstat arranges for statistical inquiries to be conducted in accordance with the statistical work plan for the Minstat. The statistical work plan is prepared in consultation with ministries and other administrative bodies. This instrument is used by the Minstat for coordinating and approving statistical plans.

The statistical work plan is developed in an iterative way, starting with submissions from the heads of each department. The Department of Planning and Statistical Monitoring in the Minstat then drafts the entire work plan for consideration and approval by the Board of Management. The statistical work plan is approved in August of each year and covers the following five years. It includes details of plans to be achieved in each department of the Minstat, and target dates for various stages of development. Each department presents information on progress and achievements at annual meetings of the Board of Management.

Article 6 provides that the State statistical authorities are financed from state budget funds in accordance with the statistical work plan that is approved by the Council of Ministers of the Republic of Belarus. Additional statistical work may be carried out through supplementary financing from the state budget or funds provided by those requesting this work. The work plan sets out all statistical activities to be undertaken by the Minstat during the course of the plan, including target dates for completion of specific tasks. It is the responsibility of each department's head to ensure that their components of the work plan are completed satisfactorily. The statistical work plan is reviewed annually by the Board of Management of the Minstat. There is a certain amount of flexibility to incorporate any important new statistical activity between annual reviews where a major new statistical requirement has been articulated by the government.

Under Article 12 of the Law on State Statistics, State statistical authorities are required to "use international concepts, classifications, and methods in compiling statistics as the basis for ensuring the harmony and effectiveness of the statistical system of the Republic of Belarus on all official levels".

On an annual basis, a report on the specialists' performance is prepared by the head of the DPS for the Minstat. If a specialist work performance is inadequate, that specialist is terminated. Personal employment contracts for the Minstat staff are renewed every one to three years. 
Efficiencies are sought through periodic reviews of work processes. Consistent concepts, classification and other methodologies across categories are encouraged. The source data are collected and reviewed at the regional level. The PPI data are then transmitted through dedicated lines to the Minstat.

The price statistics departments of the CIS exchange documents and information on methodological approaches in order to share views.

\section{$0.3 \quad$ Relevance}

\subsubsection{The relevance and practical utility of existing statistics in meeting users' needs are monitored}

Apart from the Inter-Agency Council for State Statistics, which focuses on methodological issues, there is no committee to provide advice about new and emerging data needs. The mission considers that the Minstat should examine the desirability of establishing a more broadly based user committee to provide it with advice on statistical policy, methodology, and priority issues.

Feedback from users on the quality standards of the PPI statistics is not solicited. There are no initiatives or projects in place to facilitate feedback from users of price statistics. The Research Institute of Economics solicits user feedback on data quality from business managers. The Institute's idea was conveyed to the Inter-Agency Council for State Statistics, but due to lack of resources, the project was put on hold.

The relevance and practical utility of the PPI data in meeting user needs are not assessed in any systematic way. The Minstat has not conducted any user surveys in the field of prices statistics and does not have any mechanism in place to systematically monitor user feedback on these statistics.

Official statements of the Minstat's PPI are disseminated monthly in the mass media, particularly in newspaper such as the National Economic Gazette

\subsection{Other quality management}

\subsubsection{Processes are in place to focus on quality}

Each year the Minstat performs tasks aimed at improving the current state statistical reports. The Minstat provides instructions on filling out these reports by taking into account the suggestions made by other ministries and departments. The drafts of reports and instructions are worked out jointly by the branch departments and the Department of Statistical Planning and Organization of Statistical Survey. These drafts of reports and instructions are then considered by the Scientific-Methodological Council of the Minstat that is headed by the first deputy minister, and then approved by the Minstat's Board of Management. 
Each year, regional staffs who work on the PPI participate in statistical seminars organized by the Minstat.

Source data are routinely checked and verified. Usually, specialists for the Minstat visit the regional offices to check and to verify (a) if prices are collected correctly; (b) if acceptable goods are selected for the PPI; and (c) if goods specification are detailed enough to allow for substitution.

\subsubsection{Processes are in place to monitor the quality of the statistical program}

The Minstat's Department of Statistical Planning coordinates all work associated with the improvement and maintenance of statistical quality. The information on such issues is considered by the Board of Management. All statistical questionnaires are sent to the Department of Statistical Planning for review. Then, the questionnaires are considered by the Scientific-Methodological Council of the Minstat and approved by the Minstat's Board of Management.

The functions of the Board of Management of the Minstat include providing a clear focus on quality through close attention to methodological issues. This is, in turn, conveyed by management to staff throughout the organization. Each staff member is given a copy of a Duty Manual that, inter alia, reinforces the importance of high standards of work and the need to produce high standard statistics. In addition, staff members, as civil servants, are made aware of their responsibilities under the Law on the Civil Service, which includes references to the requirement for work of a high standard.

According to Article 3 of the Law on State Statistics, "Basic Tasks and Principles of State Statistics that is publicly available" states that the basic principles of state statistics are (a) objectivity and reliability of statistical information; (b) stability and comparability of statistical data; and (c) accessibility and openness of statistical information within the bounds set by the legislation of the Republic of Belarus.

Reviews are undertaken of all unusual movements in the price data received at the Minstat, and are traced back to the reporter, if necessary. The PPI data are disseminated twelve days after the reference period. First, the enterprises send the data to the regional statistical department on the second of the month after the reference period. Second, the regional statistical departments have three days to verify the data, and then on the fifth of the month after the reference period transmit the data to the Minstat's headquarters.

PPI data are preliminary and are subject to revisions when disseminated by the Minstat. 


\subsubsection{Processes are in place to deal with quality considerations in planning the statistical program}

There are no trade offs between timeliness and quality. The annual plan ensures that all deadlines are met, and quality price statistics are compiled and disseminated.

\section{Assurances of integrity}

\subsection{Professionalism}

\subsubsection{Statistics are produced on an impartial basis}

Article 4 of the Law on State Statistics provides that the central statistical authority is subordinate to the Council of Ministers and shall act on the basis of the regulations approved by the Council of the Republic of Belarus. The regulations are prepared by the Minstat.

Article 10 provides that interference by any government authorities, officials, and other persons in the activity of the state statistical authorities shall not be permitted, and the mission was informed that there has never been any question of interference or attempted interference with the professional independence of the Minstat.

The appointment and termination of the minister are determined by the government. Upon election of the president a new government is formed. The present Minister of Statistics was appointed in 1998. The Minstat is contemplating proposing a change from a ministry to a National Statistical Committee, to help reinforce the notion of the independence of the chief statistician, making decisions based purely on statistical considerations and free from political interference.

Recruitment and promotion of specialists in the Minstat are based on the specialists' expertise in statistics. Specialists are usually recruited from the faculty of the department of statistics at the Belarusian State Economic University. The Minstat encourages research and analysis by specialists to maintain the Minstat's reputation for professionalism.

Professionalism is also promoted through the encouragement of staff participation in training courses, workshops and seminars, to ensure awareness and understanding of statistical standards and good statistical practices.

The Minstat provides on-the-job training in prices at the regional and district levels. However, according to the Minstat, they do not have the opportunity to send their specialists in prices methodology and compilation methods to seminars and workshops arranged by the IMF Institute. The Minstat houses a statistical library where specialists can have easy access to professional literature.

The Minstat encourages specialist's research and analysis to maintain the Minstat's reputation for professionalism. 


\subsubsection{Choices of sources and statistical techniques as well as decisions about dissemination are informed solely by statistical considerations}

The sources and methods for compiling prices statistics and component statistics are fully under the control of the Minstat, and concepts and standards follow international standards to a large extent. Appropriate data sources are used throughout the compilation of the PPI. There appears not to have been any outside interference or attempted interference in matters of sources, methods, and dissemination.

Interference by any government authorities, officials, and other persons in the activity of the state statistical authorities is not permitted. There have been no known cases of interference or attempted interference.

Article 10 of the Law of the Republic of Belarus on State Statistics provide guarantees of independence in the selection of the methodology, data sources, content, and format of the data disseminated by the Minstat. According to the Minstat, there is no external interference in the conduct of its work. Article 3 of the Law on Statistics reinforces this by stating that one of the basic principles of state statistics is objectivity and reliability of statistical information.

\subsubsection{The appropriate statistical entity is entitled to comment on erroneous interpretation and misuse of statistics}

Article 10 of the Law "the Rights of State Statistical Authorities" states, among other things that the Minstat has the right to comment on the incorrect utilization and incorrect interpretation of statistical data. In cases where there are erroneous interpretations of the statistics, the Minstat will provide clarifications in the mass media (Publications in the National Economic Gazette can be used as an example). The Minstat monitors all newspapers for erroneous interpretation of the PPI and provides timely responses.

\subsection{Transparency}

\subsubsection{The terms and conditions under which statistics are collected, processed, and disseminated are available to the public}

The Minstat's web site at http://president.gov.by/Minstat/en/about/law.htm provides the Law of the Republic of Belarus on State Statistics. The terms and conditions under which official statistics are collected, compiled and disseminated are provided. These terms and conditions refer to the obligation to compile and disseminate price statistics, the confidentiality of the data reported, and other key features such as the Minstat's rights.

All statistical publications identify where more information about the Minstat and its prices statistics can be found. 


\subsubsection{Internal governmental access to statistics prior to their release is publicly identified}

Metadata for prices posted on the Minstat's web site at http://president.gov.by/The Minstat/en/main.html clearly states that there is no internal governmental access to statistics prior to their release to the public.

\subsubsection{Products of statistical agencies/units are clearly identified as such}

Products of the Minstat are clearly identified through the use of the Ministry's name and logo on the web site and in publications. In the case of joint publications, the part attributable to the Minstat is clearly identified. The Minstat requests acknowledgement when its prices statistics are used for reproduction in other agencies' or ministries' publications.

\subsubsection{Advanced notice is given of major changes in methodology, source data, and statistical techniques}

The Minstat does not give advance notice to the public in statistical publications when major changes are introduced in methodology, sources, and statistical techniques for compilation of prices statistics. This mission was informed that prior to 2003, advance notice of planned changes, in summary form, was given to the public in the National Register of Legal Acts. However, this practice has now been discontinued. Users can obtain information on the changes in methodology, sources, and statistical techniques for compilation of prices statistics from the reference data base of regulative legal information maintained by the National Center of Legal Acts.

\subsection{Ethical standards}

\subsubsection{Guidelines for staff behavior are in place and are well known to the staff}

Articles 13 and 15 of the Law on State Statistics provide guidelines on correct behavior when the Minstat or its staff is confronted with potential conflict of interest situations.

Article 13 "Obligations of Ministries and Other Central Administrative" stipulates that authorities that maintain state statistics are required to preserve state and commercial secrecy.

Article 15, "Liability for Violations Committed while Using Statistical Data," states that employees of state statistical authorities, ministries, and other central administrative authorities who maintain state statistics shall bear liability in accordance with the legislation of the Republic of Belarus for violating the requirements of this Law concerning the collection and use of statistical data and for concealing and distorting them.

Requirements regarding staff behavior are notified in the Duty Manual, which is provided to each staff member. The Law on Civil Service also provides guidelines about staff behavior. This Law was recently amended and training courses were arranged to inform staff about their responsibilities. 
All new staff is required to sign an employment contract that outlines the ethical standards, and are reminded annually of these standards.

The Law on Civil Service requires civil servants to observe culture of communication and other norms of business ethics, not allow actions that negatively affect civil service, maintain confidentiality about work activities, and observe internal regulations of work procedures, especially with those related to confidential information. It provides guidelines about staff behavior, including the need to ensure the preservation of the confidentiality of data for individual entities. This Law was recently amended and training courses were arranged to inform staff about their responsibilities.

\section{Methodological soundness}

\subsection{Concepts and definitions}

\subsubsection{The overall structure in terms of concepts and definitions follows internationally} accepted standards, guidelines, or good practices

In the Minstat's compilation of PPI statistics, key concepts and definitions are in accordance with the guidelines of the 1993 SNA and broadly follow internationally accepted good practices. The methodology for compiling the PPI is described in detail in the publication Methodological Guideline in Statistics (2003).

Output estimates are compiled at the subgroup or five digit levels for industrial detail.

\subsection{Scope}

2.2.1 The scope is broadly consistent with internationally accepted standards, guidelines, or good practices

The PPI covers total industry and is given with breakdown by 14 main branches of industry, which are (a) electric power, (b) fuel, (c) ferrous, (d) chemical and petrochemical,

(e) machine-building and metal cutting, (f) logging, wood-working and pulp and paper,

(g) building materials, (h) glass, porcelain and faience, (i) light industry, (j) food,

(k) microbiological, (l) fodder, flour and grains, (m) medical, (n) other industries. The PPI cover timber processing, fishing, and construction activities, but does not cover agriculture and forestry.

There is no service type industries included in the output price index. The DPS has studied the feasibility of including services in the index, but found the task too difficult. All types of resident market enterprises are in scope for the PPI. Enterprises such as free zones, bonded warehouses, and factories operated by offshore enterprises under customs control are covered in the index. 
Changes in output inventories and own-account production of market goods for own final consumption, output of market goods for own-account fixed capital formation, illegal market goods, market services production for sale, production of selected services for own final consumption, production of services for own account fixed capital formation, and illegal market services sold to willing buyers are not included in the index.

\subsection{Classification/sectorization}

\subsubsection{Classification/sectorization systems used are broadly consistent with internationally accepted standards, guidelines, or good practices}

The 1993 SNA is followed to classify institutional units and transactions. The published industry indices use International Standard Industrial Classification of all Economic Activities (ISIC) Revision 3, while partial Standard Classification of Economic Activities within the European Communities (NACE) is also used to classify the principal economic activity of enterprises at the most detailed level. Proposals have been submitted to classify products according to the classification of products by activity.

\subsection{Basis for recording}

\subsubsection{Market prices are used to value flows and stocks}

The valuation rules used for recording flows are in accordance with $1993 S N A$. The timing used for recording flows is based on the sales of the period. The valuation rule used for valuing the output (for the weights of the PPI) and the product prices collected is based on basic/producer prices. Outputs for own-use are not covered in the PPI (only sold products are covered).

Prices collected are basic prices received by the producer. VAT and consumption taxes are excluded. Subsidies on products are included.

There are no valuations for intermediate consumption. All valuations are based on goods for final production. The production specifications include transaction characteristics, such as transactions between units of the same enterprise valued at transfer price.

\subsubsection{Recording is done on an accrual basis}

Outputs of finished goods are recorded in the period they are produced.

2.4.3 Grossing/netting procedures are broadly consistent with internationally accepted standards, guidelines, or good practices

There are no stage of processing indices produced, and therefore no grossing or netting is conducted. In addition, there are no problems with transactions between establishments of the same enterprise. 


\section{Accuracy and reliability}

\subsection{Source data}

\subsubsection{Source data are obtained from comprehensive data collection programs that take into account country-specific conditions}

A comprehensive and up-to-date business register provides the basis for sample surveys. The business register is updated annually and covers all enterprises. The weights for the PPI are based on product data obtained from these surveys.

The PPI statistical survey is derived from the business registry. The resulting data from the survey are kept under continuous review to ensure that all data are comprehensive. On an annual basis, specialists in the Minstat thoroughly review the business registry to identify new enterprises and products to include into PPI, and to delete dead units and accounting for mergers and changeovers. The majority of the enterprises is large and medium entities that are always kept in the sample. Small enterprises are selected, but there is a panel rotation for these small enterprises that is done in order to minimize any bias caused by sample attrition.

The data sources of the data collection program are broadly sufficient to compile the PPI. Nine hundred and fifty-six enterprises are included in the survey for 3,000 products.

Information from the Department of Statistics of Enterprise and Fuel, Energy Complex is used to supplement the core compilation.

The sample is selected on a judgmental basis (random sampling is not used). For the enterprise selection, first industries are selected, then sub-industries, followed by the decision of what production of activities to select, then after enterprises are selected.

For the product selection, first the commodities (product groups) are selected in the 4-digit classes by judgmental sampling (the most important groups), then the main producers (enterprises) of the selected commodities are selected, and, finally, from these enterprises, the particular price-representing products are selected, also by judgmental selection.

Survey questionnaires are agreed upon according to pilot testing of the enterprises, and during the design of the survey questionnaires.

The survey coverage of activities for the main industrial group is 68 percent. Within the most important industries the coverage is much wider. For example, in electric power the coverage is 91 percent, in chemical 91 percent, building materials 82 percent, glass, porcelain, and faience 77 percent. The coverage is narrower in the industries that have numerous enterprises in the Republic of Belarus, (a) food (63 percent), and (b) logging, wood-working and pulp and paper (59 percent). The mission felt that coverage is inadequate. According to the InterSecretariat Working Group on Price Statistics, the broader the coverage of the PPI in terms of 
economic activities, the more useful it is in inflation analysis and compiling constant price GDP estimates. The PPI does not cover service industries, and the mission felt that the Minstat should develop sampling frames for a wide range of economic activities that include services.

Unfortunately, there are no periodic meetings held with enterprises to identify new developments that are needed to be taken into account in the PPI compilation. This problem highlights the need for a users' group.

\subsubsection{Source data reasonably approximate the definitions, scope, classifications, valuation, and time of recording required}

Source data are consistent with the definition, scope, and classifications of PPI statistics. All source data on prices from enterprises selected from the business registry are specifically collected for the compilation of the PPI.

On the basis of the statistical register, the Minstat selects a list of enterprises for inclusion into the producer price survey. The enterprise surveys cover all enterprises regardless of size. The surveys are conducted according to the national classification of economic activities. This list of enterprises is provided to the regional departments of price statistics. The regional departments then select the goods for the price survey jointly with the specialists of the selected enterprises.

On the surveys, enterprises are asked to provide product prices and production volumes. The survey explicitly asked that enterprises provide production volumes information on recent period's inventory. A carefully designed product specification survey is first developed in the Minstat that includes pertinent price determining characteristics. The enterprises are then asked to report the price of the selected product specifications each month.

This product specification includes information such as size, color, weight, volume, speed, and power. All surveys indicate the deadline (on the second of the month after the reference period) in which the survey should be completed and mailed to regional offices. The basis of recording, which excludes value-added and excise taxes and transport charges, are also included on the survey form.

Specialists in regional offices often provide standing seminars for enterprises on how to correctly fill out surveys, and answer any questions pertaining to data collection in order to facilitate timely response.

\subsubsection{Source data are timely}

Enterprises present data on the transactions made within the month for the selected product. By the second day of the month after the reference period, surveys should be received in the regional offices for tabulation. On the fifth day of the month, the regional offices send their 
reports to the Minstat headquarters for weighting and compilation. According to the Minstat, all surveys from all enterprises are received on time and there is a 100 percent response.

\subsection{Assessment of source data}

3.2.1 Source data-including censuses, sample surveys and administrative records-are routinely assessed, for example, for coverage, sample error, response error, and nonsampling error; the results of the assessments are monitored and made available to guide statistical processes

Information about errors for each survey conducted is monitored on a monthly basis. Information on weights, price relatives, misclassifications, and outliers are routinely checked. Problems of no response are uncommon due to the established relationships between the statistical authorities and the enterprises. Imputations are done to account for any misclassifications. If there were a mistake with last month's price, the specialist would be alerted and corrections to previous data would be done.

All large movements in prices are traced back to the enterprise if warranted and are verified. Post-enumeration checks are made, and the index is revised back to two months. Pilot testing is done to analyze the effects of changes in the survey questionnaires. Comments and recommendations are solicited from the enterprises in order to design a better enterprise survey.

There are no administrative data and other secondary sources.

\subsection{Statistical techniques}

\subsubsection{Data compilation employs sound statistical techniques to deal with data sources}

The PPI is collected and tabulated first at the regional level, then in the Minstat's headquarters. At the regional level, enterprise surveys are verified, checked, and then entered into the computer system. Upon receipt in the Minstat's headquarters, elementary aggregates are first weighted and calculated for product by basis arithmetic mean of price ratios, second by sub-industry, third by industries, and fourth for the Republic of Belarus as a whole using a Laspeyres index approach.

Compilation procedures minimize processing errors such as coding, editing, and tabulation errors. In 2003, the DPS developed new PPI software. This software enables specialists to identify any errors such as sampling, nonsampling, and observation errors.

Adjustments to unit records are made only when clearly warranted and can be identified in the price tabulations. When outliers are identified, the data are first verified from the datasets in the Minstat's headquarters, and then the regional offices are contacted if adjustments are needed. 
Procedures for imputation and adjustment are soundly based. There are no failures to obtain the required information in a timely manner from all enterprises selected in the sample.

Specialists in the regional offices often provide standing seminars for enterprises on how to correctly fill out surveys, and to answer any questions pertaining to data collection in order to facilitate timely response.

No adjustments are necessary to adjust data sources to improve coverage since data sources are derived from the business registry. All enterprises have to be registered and an annually up-to-date business register exists.

Prices for temporarily missing products are imputed based on the change in price of similar products using the match sample technique. However, in certain cases, the last reported price is carried forward. Missing prices for seasonal products are imputed at the sub-industry level. Products that become permanently unavailable are replaced in the sample and back corrections are made to adjust the base price.

The design of the product specification allows for such replacements. Quality adjustments for products are conducted, usually using both implicit and explicit quality adjustment methods.

New products are introduced into the sample as they gain market share. However, the normal practice is to defer introduction of those products into the PPI until the following year when the weights are updated.

\subsubsection{Other statistical procedures (for example, data adjustments and transformations, and statistical analysis) employ sound statistical techniques}

At the elementary level, an arithmetic mean or the ratio of average prices is used to calculate the index. Short-term price change is calculated for prices in the last three months and prices for the previous month. Long-term price change is calculated for a historical chained index with December $1990=100$.

The method used to aggregate the elementary indices to higher levels is a Laspeyres formula. The present PPI weights refer to the year 2002. The weights are fixed at the item level, and are adjusted for price change to align them with the appropriate price reference period. The weights for the PPI are compiled using data from the business surveys on values of goods produced. These weights are revised annually and introduced into the index in January. New weights are introduced by the normal linking process, and nine months are needed to link the old index to the new index.

These weights are shares in gross output, as defined in the $1993 \mathrm{SNA}$. Work in progress (work currently under production), production such as growing crops, standing timber, stocks of fish, and large construction projects are not included in the PPI. The PPI has output weights that it compiles from establishment reports of output. 
Producers who own their buildings and factories do not provide imputed rents for the PPI. All products are priced at actual transaction price.

\subsection{Assessment and validation of intermediate data and statistical outputs}

\subsubsection{Intermediate results are validated against other information where applicable}

The PPI is checked against the relevant components of the CPI.

\subsubsection{Statistical discrepancies in intermediate data are assessed and investigated}

Unusual movements in the index arising from large movements in particular sectors or from particular enterprises are investigated and explained in descriptive documentations. Errors found during verification of the reported data on producer prices are analyzed by the Minstat and sent to the regional statistical department to prevent them in the future. Findings from these statistical discrepancies are shared with the specialists at the regional offices with the hope that future errors can be avoided. However, these documents are not available to the public.

No information is available about sampling errors for the monthly statistical survey collecting product prices for the PPI because random sampling is not used.

There are minimal problems with nonresponse. Monthly statistical surveys for collecting producer prices are followed-up by the regional specialists by a telephone call or a personal visit when surveys are not received on time.

\subsubsection{Statistical discrepancies and other potential indicators of problems in statistical outputs are investigated}

Discrepancies arising from inconsistent imputation for missing data, seasonal goods, and quality adjusted goods are routinely assessed. There are ranges of control edits supported by computer programs that can be used to assess and validate the data.

\subsection{Revision studies}

\subsubsection{Studies and analyses of revisions are carried out routinely and used internally to} inform statistical processes (see also 4.3.3)

PPI data are first released as preliminary, and then two months later, PPI data become final. Revised data are identified by footnotes in the statistical publications.

Once per year, weights are routinely analyzed to determine the effects of structural changes in the index; new and old structures of weights are compared. Source data are analyzed to determine nonsampling errors. 
Adequate documentation on these revision studies is well maintained and includes methods used to incorporate new data sources, and the way data are adjusted. All proposals for weight revisions must be approved by the Scientific-methodological Council of the Minstat.

\section{Serviceability}

\subsection{Periodicity and timeliness}

\subsubsection{Periodicity follows dissemination standards}

The periodicity of the statistics follows the SDDS requirements. PPI data are compiled monthly.

\subsubsection{Timeliness follows dissemination standards}

The monthly estimates are disseminated within one month after the end of the reference month. Summary PPI statistics are disseminated 12 days after the end of the reference period, while more detailed PPI data are disseminated 21 days after the end of the reference period, and, accordingly, exceeds SDDS requirements.

\subsection{Consistency}

\subsubsection{Statistics are consistent within the dataset}

Consistent PPI series are published for industry and product classifications.

\subsubsection{Statistics are consistent or reconcilable over a reasonable period of time}

Time series data are available for the last fourteen years. Historical time-series data are available for December $1990=100$. In July 1993, the IMF Technical Assistance mission recommended that the new PPI and historical time-series should be officially published so that other government agencies, businesses and international organizations can take advantage of the State Statistical Committee's most reliable broad-based measure of the general level of inflation for the Republic of Belarus. During the mission the historical time series for 14 years were published (December $1990=100$ ), therefore meeting the no less than five years requirement of good statistical practices. The infrequent publications of long time series data of five years or greater, with a given reference base, does not meet international good practice for index publication. This historical time-series is only published in the National Economic Gazette, and not in any official statistical publications.

The DPS hyperlinked the PPI historical time-series to the Minstat's web site during the mission. The availability of historical time-series is a requirement of the SDDS. 


\subsubsection{Statistics are consistent or reconcilable with those obtained through other data sources and/or statistical frameworks}

PPI data are largely consistent with the CPI statistics.

\subsection{Revision policy and practice}

\subsubsection{Revisions follow a regular and transparent schedule}

PPI data are revised once published, and the index weights of the PPI are updated annually. The new weights are normally introduced with data published in January.

The public is aware of the annual weight updating of the PPI.

\subsubsection{Preliminary and/or revised data are clearly identified}

Both preliminary and revised PPI data are clearly identified.

\subsubsection{Studies and analyses of revisions are made public (see also 3.5.1)}

The impact of annual weight updating studies is not disseminated in official statistical publications, but would be appropriate for the annual PPI statistical bulletins.

\section{Accessibility}

\subsection{Data accessibility}

5.1.1 Statistics are presented in a way that facilitates proper interpretation and meaningful comparisons (layout and clarity of text, tables, and charts)

PPI data are published in a clear manner. In certain publications, charts and tables are also disseminated with the data to facilitate analysis. Datasets are published in consolidated format as a whole, by industries, subindustries, by means of production, intermediate, and consumer good. In all statistical publications, the PPI data are published for the Republic as a whole against the previous month and also against December of the previous year. Chain-linked historical time series data are disseminated in the National Economic Gazette on an infrequent basis.

Relevant series are not disseminated in a seasonally adjusted form, and there are no plans to seasonally adjust the data.

\subsubsection{Dissemination media and format are adequate}

PPI data are disseminated in ways that facilitate redissemination in the media through official press releases and internet web site. The data are simultaneously disseminated to all 
interested parties through a press release prepared by the Minstat, "Balta," which is a monthly press release. Data are also simultaneously disseminated on the Minstat's internet web site http://president.gov.by/Minstat/main.html.

More comprehensive and/or detailed statistics are also disseminated. Requests for these types of data are usually completed in five days and longer if requests are labor intensive.

PPI data are published for the Republic as a whole against the previous month and also against December of the previous year are published on the Minstat's web site.

\subsubsection{Statistics are released on a preannounced schedule}

An advance release calendar is posted on the Minstat's web site, http://president.gov.by/Minstat/main.html, with release dates for the upcoming three months.

PPI data are usually released punctually on the $12^{\text {th }}$ of the month. If the $12^{\text {th }}$ is not a working day, the PPI is released on the prior Friday before the $12^{\text {th }}$.

\subsubsection{Statistics are made available to all users at the same time}

PPI data are transmitted simultaneously to all users on the $12^{\text {th }}$ of the month, or the prior Friday before the $12^{\text {th }}$ of the month, usually through the press release.

\subsubsection{Statistics not routinely disseminated are made available upon request}

Detailed customized tabulation (detailed breakdowns) of PPI data is available upon request, in addition to the PPI routinely disseminated. For specific purposes, customized tabulation of data that satisfy the Minstat's disclosure requirements is also available for a fee.

Data users are aware of the availability of additional statistics and of the procedures for obtaining them. These procedures are explicitly provided in statistical publications.

\subsection{Metadata accessibility}

5.2.1 Documentation on concepts, scope, classifications, basis of recording, data sources, and statistical techniques is available, and differences from internationally accepted standards, guidelines, or good practices are annotated

Limited PPI methodologies are provided in (a) the Statistical Yearbook of the Republic of Belarus, 2003, (b) the Consumer Price Indices, (c) the Quarterly Statistical Bulletin, and (d) the Price Indices for Consumer Goods and Services, and for Produced Industrial Goods. Very detailed methodological descriptions are provided in statistical publications, such as Methodological Guidelines and Methodological Guidelines on Statistics; however, these publications are not easily accessible to the public. The users can obtain information in the reference database of the regulative-legal information. 
There is no published information in official statistical publications on the survey sources, such as the response rates, survey monitoring, non sampling errors, sample frame, sample design, estimation, and imputation techniques. However, references are made of the administrative data sources used.

The Republic of Belarus is expected to subscribe to the SDDS in the near future. However, there are PPI metadata in SDDS format that are posted on the Minstat's web site, though there are no SDDS summary methodologies on PPI at this time.

\subsubsection{Levels of detail are adapted to the needs of the intended audience}

There are no pamphlets, brochures, background papers, or working documents about the PPI and other prices statistics that are made available to the public on a frequent basis.

\subsection{Assistance to users}

\subsubsection{Contact points for each subject field are publicized}

A contact person with telephone, facsimile, email, and internet address is provided on the inside of most price statistics publications.

Assistance to users is monitored and reviewed periodically. According to the Minstat, when requests are made for PPI data, the General Department logs these requests with a number, and tracks when the request was made and implemented. Users, however, said that request for data are not met in a timely manner.

\subsubsection{Catalogs of publications, documents, and other services, including information on any changes, are widely available}

The Minstat publishes a comprehensive print catalogue of all of its publications. This catalogue is annually updated. The prices of the statistical products and services are not disclosed due to the frequent changes in price. Prices are listed as contractual. 
Table 3. Republic of Belarus: Data Quality Assessment Framework (July 2003): Summary of Results for Price Statistics (Producer Price Index)

(Compiling Agency:Minstat

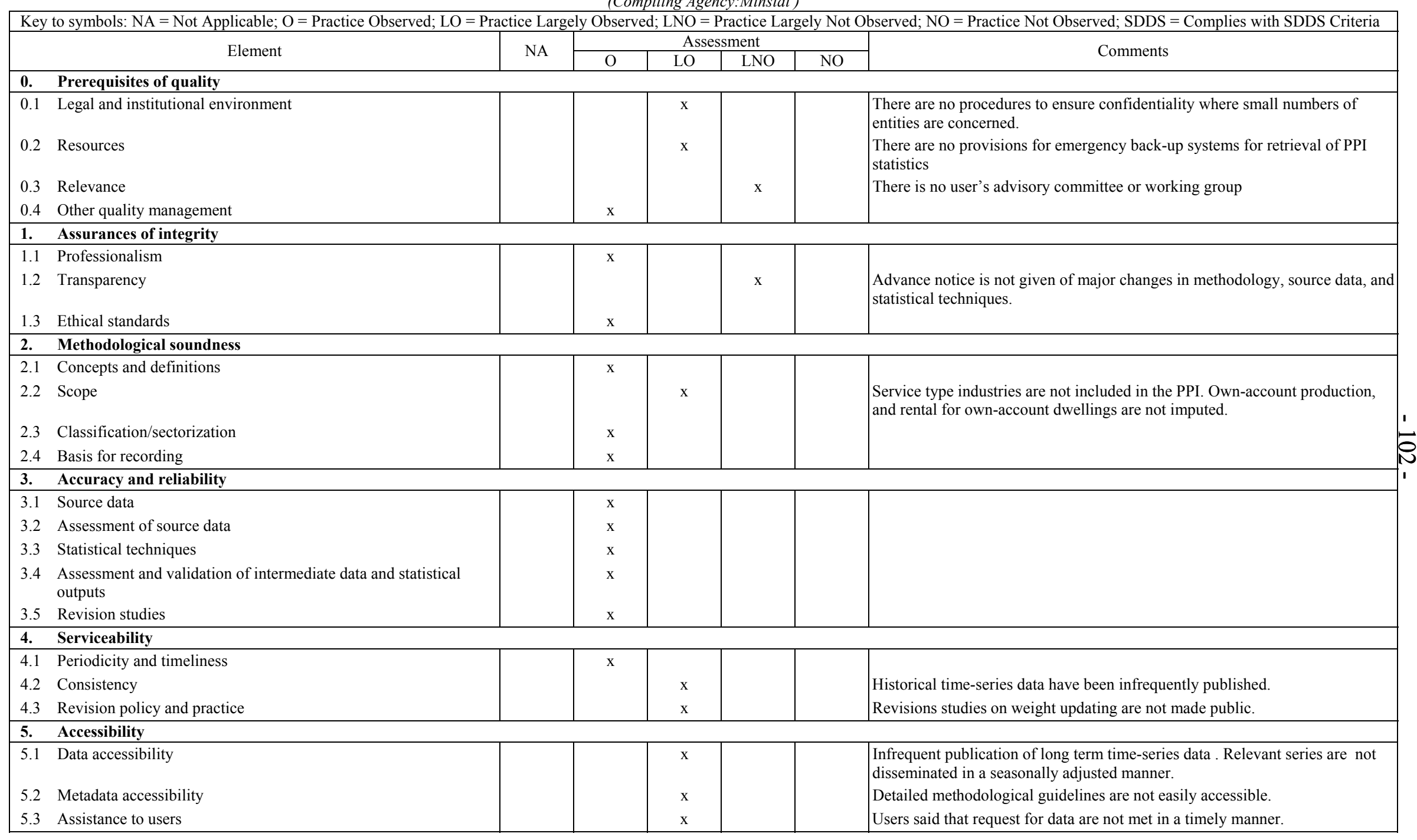

CInternational Monetary Fund. Not for Redistribution 


\section{Government FinanCe Statistics}

\section{Prerequisites of quality}

\section{$0.1 \quad$ Legal and institutional environment}

\subsubsection{The responsibility for collecting, processing, and disseminating the statistics is clearly specified}

Government finance statistics (GFS) ${ }^{15}$ on the general government operations are collected, compiled, and disseminated by the Ministry of Finance (MoF). The responsibility for compiling GFS is clearly specified in the Provision on Structural Units of the MoF (Order No. 322 of March 12, 2002). Article 8.4 states that the Budget Policy, Financial Analysis, and Forecasting Division of the MoF (BPFAFD) shall compile GFS in accordance with international standards. Article 9.14 states that the BPFSFD shall compile and submit GFS to the IMF, the Minstat, the NBRB, and other Belarusian agencies concerned. This provision also states that the GFS are prepared on the basis of reporting on the execution of consolidated budget of the Republic of Belarus (including state earmarked budgetary and extrabudgetary funds). The BPFAFD is also in charge of the compilation of budget data. The BPFAFD regularly provides GFS to the IMF for publication in International Financial Statistics and the Government Finance Statistics Yearbook. The BPFAFD also provides fiscal data to the IMF's European Department. Additionally, the MoF compiles and disseminates some fiscal statistics, including those that may fulfill the SDDS requirements, and prepares analytical fiscal reports that include tables and graphics that are also disseminated on its web site on a monthly basis.

The compilation and dissemination of the budget execution data are conducted in accordance with the terms and conditions established in the following laws: (a) the Constitution of 1994 (and its amendments provided by the Republican Referendum of November 24, 1996); (b) Law on the Budget System of the Republic of Belarus and State Extrabudgetary Funds (law No. 2347-XII of June 4, 1993); (c) Law on the 2004 Budget of the Republic of Belarus (law No. 259-3 of December 29, 2003); (d) Law on Budget Classification (law No. 158-3 of May 5, 1999); (e) Law on the Internal Government Debt of Republic of Belarus (law No. 2328-XII of May 27, 1993); (f) Law on the External Government Debt of the Republic of Belarus (law No. 170-Z of June 22, 1998); (g) Law on Accounting and Reporting and its amendments (law No. 42-3 of June 25, 2001); (h) the Provision on Accounting Reports of Organizations financed by the Budget (provision No. 13 of January 30, 2002); and (i) Law on

\footnotetext{
${ }^{15} \mathrm{GFS}$ refers to fiscal data compiled and disseminated, for analytical purposes, according to international accepted standards, such as A Manual of Government Finance Statistics 1986 (GFSM 1986) and the Government Finance Statistics Manual 2001 (GFSM 2001). Fiscal data refers to GFS and budget data.
} 
Local Government and Self-government in the Republic of Belarus (law No. 617-XII of February 20,1991). These laws provide adequate support for the production of the fiscal data for budget management and GFS.

Article 34 of the Constitution states that the citizens should be guaranteed the rights to receive, store, and disseminate complete, reliable, and timely information of the activities of state bodies and public associations, on political, economic, cultural, international, and environmental grounds. The use of information may be restricted to safeguard the honor, dignity, personal, and family aspects of the citizens and the complete implementation on their rights. Regarding budget issues, article 133 of the Constitution states that the budget system of the Republic of Belarus should include the national budget and local budgets, and article 134 states that the procedures for preparation, approval, and implementation of budgets and extrabudgetary funds should be determined by law.

The Law on the Budget System of the Republic of Belarus and State Extrabudgetary Funds defines the principles that rule the budget system and establishes the general guidelines for the compilation, approval, and execution of budgets. Article 5 states that the budget system of the Republic of Belarus comprises the Republican and local budgets as its independent components, and article 11 states that approved budgets and reports on the execution of the budget should be published in the press. Also, article 20 states that the MoF will compile a report on execution of the consolidated budget of the Republic of Belarus for the previous (fiscal) year, including reports on executions of the Republican budget and budgets of oblasts and the city of Minsk, and they should be submitted to the government of the Republic of Belarus. The report on annual budget execution should be approved by the Parliament of the Republic of Belarus. Article 8 establishes the procedures to provide effective and timely flow of source data and that the consistency of the budget will be ensured by (a) a unique legislative baseline; (b) a single form of budget documentation; (c) a single budget classification; and (d) the reporting of statistical and budgetary information of Republican and local budgets for the compilation of consolidated budget, and coordinated principles of the budget process.

The Law in the 2004 Budget of the Republic of Belarus approves the Republican budget for 2004 on expenditures proceeding from predicted revenues, establishes the maximum deficit, and determines sources for the financing of the deficit.

The Law on Budget Classification provides the definitions of budget classification of the Republic of Belarus. This is a single classification used for compilation, approval, and execution of the Republican and local budgets, state earmarked budgetary funds, and extrabudgetary operations. The budget classification includes (a) a revenue classification; (b) expense classifications that comprise functional, economic, and institutional classification; (c) a classification of domestic financing; (d) a classification of external financing; (e) a classification of domestic debt; and (f) a classification of external debt. 
The Law on Internal Government Debt of the Republic of Belarus presents the definition and characteristics of government's domestic debt, including the government guaranteed debt, and defines the procedures for its management.

The Law on External Government Debt of the Republic of Belarus presents the terms and conditions of government's foreign debt. This law establishes that the government's foreign loans should be set up in accordance with the budget of the Republic of Belarus. Additionally, this law includes the procedures for the execution of the government guarantees on government's foreign debt.

The Law on Changes and Amendments in the Law of the Republic of Belarus, "On Accounting and Reporting," states in article 13 that the MoF determines the composition of accounting records of organizations that are financed from the budget. Also, the Provision on Accounting Reports of Organizations financed by the Budget states that all legal entities will provide accounting financial reports to the MoF. These data will include a balance sheet.

The Law on Local Government and Self-Government in the Republic of Belarus ${ }^{16}$ states in article 9 that the oblasts' and Minsk City's executive committees will submit to the Republican body of the government administration in charge of public finances, consolidated budgets for the next fiscal year and report on execution of budgets for the previous year taking into account procedures and deadlines specified by this body. Article 40 states that the financial resources of the local governments consist of budget and extrabudgetary resources of councils, executive committees, local administrations and self-government bodies.

The Law on State Statistics (law No. 18-3 of February 17, 1997) states the basic tasks and principles of State statistics. The basic tasks include the submission of statistical information to governmental authorities and its dissemination among other users. Article 5 states that the ministries and other central administrative authorities should maintain statistics in accordance with the forms and methodological instructions approved by the central statistical authority (the Minstat). Also, article 8 states that all legal entities should be required to submit statistical reports taking into account the forms, deadlines, and specifications approved by the central statistics authority, and article 11 states that the ministries that maintain State statistics should supervise the recording and reporting, and verify the reliability of the statistics provided. In practice, the Minstat does not send any format or methodological specifications to the MoF. The fiscal data used by the Minstat are prepared with the format and methodology provided by the MoF. Article 13 establishes the obligations of the ministries to (a) ensure collection, processing, and reliability of statistical data; (b) submit data to the State statistical authorities required to perform their statistical activities; and (c) preserve state and commercial secrecy.

\footnotetext{
${ }^{16}$ Local self-government is a form of organization of citizens with the purpose of implementing social, economic, political, and cultural issues.
} 
The MoF has recently drafted the Budget Code of the Republic of Belarus to replace the Law on the Budget System of the Republic of Belarus and State Extrabudgetary Funds. The MoF expects to submit the draft of the Budget Code to the Government by July 2004.

\subsubsection{Data sharing and coordination among data-producing agencies are adequate}

Data sharing and coordination among the MoF, the Ministry of Economy, the NBRB, and the Minstat are adequate. However, the budgetary data provided to the NBRB is not enough for reconciliation of the fiscal and monetary data. Although there are no formal working arrangements to ensure regular reconciliation of monetary, balance of payments, national accounts, and fiscal data, article 21 of the Law on the Budget System of the Republic of Belarus and State Extrabudgetary Funds establishes that the MoF, the Ministry of Economy, and the NBRB should coordinate the preparation of the main economic assumptions and the basic guidelines of the budget and financial policies. Also, this law states that the Minstat and the NBRB will submit statistical information needed to prepare projections of socioeconomic developments and budgets to the MoF and local executive branches.

\subsubsection{Individual reporters' data are to be kept confidential and used for statistical purposes only}

The confidentiality of data received from reporters is protected by the Law on National Statistics, which states that all information containing state and commercial secrets should not be subjected to disclosure and should be protected. Also, the State Secret Law (Decree of the President of the Republic of Belarus No. 129 of March 3, 1999) presents a list of datasets that constitute state secret of the Republic of Belarus. This list includes data on financial transfers and payments from the Republican Budget that data disclosure may entail grave consequences for national security, defense, political, and economic interests of the Republic of Belarus. In addition, article 21 of the Law on Civil Service in the Republic of Belarus (law No. 204-3 of June 14, 2003) states, among the obligations of civil service, that civil servants must not disseminate state secrets entrusted to them, and the disclosure of state secrets could result in their dismissal of the civil service.

\subsubsection{Statistical reporting is ensured through legal mandate and/or measures to encourage response}

The Law on the Budget System of the Republic of Belarus and State Extrabudgetary Funds enforces each administrative authority of the Republican budget and local governments to submit to the MoF consolidated budgets (in the case of local government, the consolidated budget will include budget information of the oblasts and the city of Minsk) and reports on the execution of budgets within the deadlines established by the MoF. Also, at the request of the MoF, banks provide information about the status of the financial accounts of ministries, other Republican government authorities, state extrabudgetary funds, other legal entities, and individuals that use financial resources of the budget and extrabudgetary funds. 
In addition, article 22 of this law on the budget system states that the MoF has the rights to restrict and suspend the financing of expenditures in the event that recipients failed to provide information or not use resources for designated purposes. Article 29 states that the MoF will prepare and submit to the President of the Republic of Belarus, for presentation to the Parliament, a report on execution of Republican budget no later than five months after the last day of the fiscal year.

The laws on domestic and foreign government debts status that the MoF shall maintain records of domestic and foreign government debts, as well as records of debt of local councils of deputies. Also, this legislation requires a uniform system for the registration and management of foreign government loans in the MoF.

The law on accounting and reporting states that the MoF outlines the types of reports, data reporting requirements (including periodicity), a calendar for reporting, and penalties for not reporting the information requested by this unit. These reports and formats are defined by the Provision on Accounting Reports of Organizations Financed by the Budget. Also, this law says that state enterprises will submit accounting reports to the general government units authorized to manage their state property.

Additionally, there are administrative provisions for collecting the information necessary to compile budget execution reports, such as the provision of assistance to reporters in completing and submitting forms and the preparation of a calendar for reporting data to the MoF. There is a recognition in the MoF about the high level of compliance of the budgetary and local government units in reporting data.

\section{$0.2 \quad$ Resources}

\subsubsection{Staff, facilities, computing resources, and financing are commensurate with statistical programs}

GFS are compiled by one economist in the BPFAFD of the MoF. This GFS staff compilation work is supervised by the head of BPFAFD and is done in addition to the staff's other regular tasks. Although the staff's qualifications are adequate to perform the required compilation tasks, the authorities of the MoF should increase the number of personnel involved in GFS compilation, especially if the MoF decides to migrate to the new analytical framework. The MoF does not experience a high staff turnover.

The economist in charge of GFS compilation participated in a GFS course based on GFSM 1986 methodology in 1999, and this staff member is scheduled to attend the GFS Joint Vienna Institute course based on the GFSM 2001 in 2004. There are some measures in place to encourage the retention of experienced staff. However, there are constraints on promotion and merit increases within the civil service system.

Available computer resources are reasonable, but they need to be updated. Although software utilized for compiling GFS is adequate for current needs, this software has problems for the 
conversion to GFS format. This software and the software for data analysis require to be updated. The MoF has a unit in charge of information and computing issues for the entire institution. This unit provides anti-virus software, but does not keep back-up of the GFS produced in the MoF.

Although physical facilities appear adequate for current GFS, financial resources for the collection, compilation, and dissemination is insufficient. The restriction will be more evident with increased future GFS activities such as for SDDS subscription and migration to GFSM 2001.

\subsubsection{Measures to ensure efficient use of resources are implemented}

The costs associated for the GFS compilation are not separately calculated. Nevertheless, the MoF carries out reviews of staff performance. These reviews are performed at least once every three years. The result of this review process is to be used for the promotion policy implemented in the MoF.

In recent years, the MoF has sought expert assistance from the IMF, especially from the Fiscal Affairs Department (FAD), to assess treasury activities, public expenditure management and budget code and budget classification. In 1993, a multitopic statistical mission from the IMF's Statistics Department visited Minsk. Also, some technical assistance have been provided by the World Bank and other international organizations.

\section{$0.3 \quad$ Relevance}

\subsubsection{The relevance and practical utility of existing statistics in meeting users' needs are monitored}

Although the MoF does not undertake research to help identify new and emerging data requirements, official letters from other public institutions, such as the State Custom Committee, requesting changes in the data compiled and disseminated are taken into account for future quality improvements in fiscal data. There are no surveys for obtaining feedback about the relevance and practical utility of fiscal data for analytical purposes, although some feedback is received from other government units, such as the State Custom Committee about the detailed information provided by the MoF.

\subsection{Other quality management}

\subsubsection{Processes are in place to focus on quality}

The MoF is fully aware that quality should be the cornerstone of the budget and statistical processes. To this end, major efforts have been put in place during the last year to compile and disseminate a more complete set of fiscal data with increased coverage of institutions (for example, the budget now includes the Social Protection Fund of the Ministry of Labor and Social Protection of Republic of Belarus), and to improve timeliness and periodicity. 
Currently, the Republic of Belarus is working to fulfill all the requirements for subscription to the SDDS.

\subsubsection{Processes are in place to monitor the quality of the statistical program}

Some monitoring mechanisms are in place to ensure consistency in the production of fiscal data. Thus, over the course of the fiscal year, the execution of the Republican Budget is monitored by the MoF and the State Control Committee. Also, for monitoring purposes, the $\mathrm{MoF}$ and local administrative authorities at the higher territorial level have the rights to request any information related to budget execution.

\subsubsection{Processes are in place to deal with quality considerations in planning the statistical program}

There are no formal processes to assess the quality of the GFS, and no medium term plan to improve data quality. However, efforts are made to ensure the internal consistency of the data and to improve quality. For instance:

- the MoF is being extended to include all extrabudgetary operations, which should result in a more complete institutional coverage;

- the MoF is working on improvements in the GFS classification, especially in the expenditure economic and functional classifications;

- $\quad$ the MoF is disseminating fiscal data on its web site; and

- $\quad$ the MoF is familiarizing itself with the new analytical framework for compiling GFS.

\section{Assurances of integrity}

\subsection{Professionalism}

\subsubsection{Statistics are produced on an impartial basis}

Although the impartial compilation and dissemination of GFS are not supported by specific laws, there is no evidence that such data are not compiled on an impartial basis. Culture of professionalism is clearly recognized as essential to the credibility of statistical results in the internal provisions of MoF that establish functions, responsibilities, and rights of the compiling unit and in the principles of the Law on Civil Service. Also, the choice and tenure of the compiling unit's head are based on independent process. Thus, the possibility for interference is highly limited.

Efforts are made to promote professionalism by sending staff to training courses abroad and by contracting experts to provide on-the-job training. Also, professionalism is fostered by 
analytical work, publication of methodological papers, and organization of lectures and seminars. Research and analysis are encouraged, and the result of these academic activities are published in the Journal of Finance Accounting Audit of the MoF. More importantly, professionalism is a key factor in the recruitment and promotion of staff, as envisaged in the Law on Civil Service. Article 6 of this law states that there is equal access of citizens to any positions of civil service and their promotion is in accordance with their abilities and professional training.

\subsubsection{Choices of sources and statistical techniques as well as decisions about dissemination are informed solely by statistical considerations}

No evidence exists of political interference in the choice of data sources and statistical methods. Data sources are selected according to the usefulness and availability of the information to compile sound GFS. Also, changes to the analytical framework are made solely for statistical reasons. The implementation of the GFSM 2001 would require changes in the current legislation and practical procedures of the GFS compilation.

\subsubsection{The appropriate statistical entity is entitled to comment on erroneous interpretation and misuse of statistics}

The MoF is empowered to respond to misinterpretation and/or misuse of fiscal data. In case of misinterpretation or misuse, the MoF prepares and disseminates explanatory notes to help correct the mistakes/misuses of fiscal data.

\subsection{Transparency}

\subsubsection{The terms and conditions under which statistics are collected, processed, and disseminated are available to the public}

The public has unimpeded access to the Law on the Budget System of the Republic of Belarus and State Extrabudgetary Funds, and the broad legal framework for collection, compilation, and dissemination of the fiscal data. ${ }^{17}$ Comprehensive terms and conditions under which the MoF collects, compiles, and disseminates GFS are not available to the public.

\subsubsection{Internal governmental access to statistics prior to their release is publicly identified}

In principle, no agency outside of MoF has access to data prior to publication, however, this practice is not publicly announced (see page 124). Procedures for authorizing dissemination

\footnotetext{
${ }^{17}$ This law is published in the National Center of Legal Information of the Republic of Belarus's web site (http://www.ncpi/gov.by).
} 
of GFS, deemed to be internal, are made public only in a limited manner. The minister of the MoF authorizes the release of GFS. Selected officials in the MoF obtain the fiscal data before other users as an internal procedure before public dissemination.

\subsubsection{Products of statistical agencies/units are clearly identified as such}

All fiscal data products that are disseminated, whether through hard copy publications or through the MoF's web site, clearly identify the producing agencies and data sources.

\subsubsection{Advanced notice is given of major changes in methodology, source data, and statistical techniques}

No advance notice is given to the public about major changes in the methodology or other relevant changes that materially affect the GFS. Explanatory notes are only provided when the changes are introduced in publications.

\subsection{Ethical standards}

\subsubsection{Guidelines for staff behavior are in place and are well known to the staff}

The ethical standards guiding staff behavior are (a) the Law on Civil Service in the Republic of Belarus, and (b) the internal provisions about the functions and obligations of the MoF staff. The law requires civil servants to observe culture of communication and other norms of business ethics, not allow actions that negatively affect civil service, maintain confidentiality about work activities, and observe internal regulations of work procedures, especially with those related to confidential information. Staff in the MoF is generally aware of ethical provisions that regulate their work. All civil servants sign a contract on joining the civil service. The signed contract includes references to ethical requirements to perform the staff's job and requires to be renewed. In the case of the MoF employees, the contract is renewed every three years. During the process of the contract's renewal, the ethical standards are reviewed and taken into account for decisions on permanence and promotion. Article 22 states that civil servants are prohibited to use, for non official purposes, materials and technical, financial, and information resources, and state property. Article 56 stipulates penalties for nonobservance of ethical standards. Thus, a civil servant may face disciplinary, administrative, criminal, or other penalties for non execution or improper execution of his official responsibilities, for violation of labor discipline, or violation of restrictions associated to the civil service. 


\section{Methodological soundness}

\subsection{Concepts and definitions}

\subsubsection{The overall structure in terms of concepts and definitions follows internationally accepted standards, guidelines, or good practices}

Concepts and definitions of the GFS reported to the IMF are generally consistent with the recommendations of the GFSM 1986. The authorities have not yet prepared a plan to migrate from the GFSM 1986 to GFSM 2001, but they expect to migrate once the decision to do so has been taken by the MoF's management. The MoF has received technical assistance ${ }^{18}$ that has provided, among other recommendations, bridge tables between national source data and those specified in the GFSM 2001 for functional and economic classifications.

\subsection{Scope}

2.2.1 The scope is broadly consistent with internationally accepted standards, guidelines, or good practices

Although the MoF maintains records of and monitors all operations made by the general government units, the scopes of the compiled GFS $^{19}$ and operations of the budget system ${ }^{20}$ are incomplete. Both of them do not include all extrabudgetary operations such as innovations funds and extrabudgetary resources of the budgetary units. Thus, these scopes are not completely in line with the recommendations of GFS methodology. According to both the GFSM 1986 and GFSM 2001, statistics should be compiled for the general government and its subsectors, that is, consolidated central and local governments. Consolidated central government should include all budgetary and extrabudgetary operations. The authorities are considering expanding the coverage of the GFS and the budget system. For 2004, the budget includes the Social Protection Fund of the Ministry of Labor and Social Protection of the Republic of Belarus, and all earmarked funds as stipulated by the Law in the 2004 Budget of the Republic of Belarus.

\footnotetext{
${ }^{18}$ The technical assistance was provided by Fiscal Affairs Department of the IMF.

${ }^{19}$ The incomplete set of GFS is reported to the European and Statistics Departments in the IMF.

${ }^{20}$ The Law on the Budget System of the Republic of Belarus and State Extrabudgetary Funds states that the budget system of the Republic of Belarus comprises the Republican and local budgets.
} 
The institutional structure of the consolidated general government in the Republic of Belarus is as follows:

- $\quad$ Republican Budget

Presidential Administration
Executive Branch
Council of ministers
Ministries
Earmarked budgetary funds
Social protection funds
Legislative Branch
Parliament
Judicial Branch
Supreme Court
Law Courts

- $\quad$ Extrabudgetary Funds

Innovations funds

Extrabudgetary resources of budgetary units

State extrabudgetary funds

- $\quad$ Local Governments (at regional, district, town, and rural levels)

The Law on the Budget System of the Republic of Belarus and State Extrabudgetary Funds states in Article 16 that the budget classification includes revenues, expenditures, and financing for the Republican, local budgets, state extrabudgetary and budgetary earmarked funds, and extrabudgetary resources of institutions and organizations supported by the budget.

The earmarked budgetary funds consist of the accumulation and use of financial resources that are part of the Republican and local budgets and used as earmarked (as defined in the draft of the budget code). There are six earmarked funds, (a) the Republican and Local Environmental Protection Funds; (b) the Republican and Local Highway Funds; (c) the State Employment Fund; (d) the Republican Energy Conservation Fund; (e) the Republican Fund for Support of Producer of Agricultural Goods and Food and Agrarian Science; and (f) the Local Targeted Budget-Financed Housing and Investment Funds.

The Social Protection Fund of the Ministry of Labor and Social Protection of the Republic of Belarus are included in the annual budget for 2004. The Social Protection Funds includes pensions funds and social insurance funds. 
The innovations funds are based on compulsory deductions of the financial resources of the state-owned legal entities. They are ruled by the Provision on the procedure of formation and use of innovations funds resources, approved by the Resolution of Council of Ministers, No. 1346 of September 30, 2002, and the laws on annual budgets.

The extrabudgetary resources of budgetary units are those funds subordinated to government ministries, agencies, and organizations. Article 36 of the Law on the 2004 Budget provides a detailed list of ministries, committees, and organizations whose revenues from various activities, such as sale of assets, including real estate, and provision of paid services, are not included in the Republican budget.

The state extrabudgetary funds are covered by article 37 of the Law on the Budget System of the Republic of Belarus and State Extrabudgetary Funds. Those funds comprise the financial resources for designated purposes. The creation of state extrabudgetary funds, the financial resources for their creation, and the procedures of their use should be established by the President of the Republic of Belarus. Article 38 establishes that the resources of the state extrabudgetary funds are not part of the budgets, and article 39 states that the MoF should monitor these resources. In practice, no institution is classified under this category.

The local governments consist of six regional (oblast) and Minsk city governments, 118 districts (rayons), 110 rayon-level cities and towns, 25 district in cities and towns, 101 semiurban centers, 1,441 rural councils, and 24,049 rural settlements.

The presentation of GFS compiled by MoF closely follows the Summary Table of Major Components in the GFSM 1986. In addition, the MoF disseminates tables for the consolidated central government that follow the format of tables A (government revenues and grants), B (expenditure by function), and C (economic classification of expenditures and lending minus repayments). There are tables for financing by type of debt holder, and by type of debt instrument (tables D and E). The tables on debt cover external and domestic debt. Also, tables on local governments (table L) are included in the annual report.

\subsection{Classification/sectorization}

\subsubsection{Classification/sectorization systems used are broadly consistent with internationally accepted standards, guidelines, or good practices}

The sectorization of the institutional coverage is not consistent with the international standards because there is not a definition of consolidated central government that includes all extrabudgetary accounts as established by the accepted international standards. Such recommendations call for statistics on (a) the consolidated central government including the Republican budget, social security schemes, and all extrabudgetary funds; (b) the consolidated general government, including the consolidated central government and local governments; and (c) the consolidated nonfinancial public sector, including the consolidated general government and the consolidated nonfinancial public corporations. 
The budgetary classification established by the Order of the MoF of Budget Classification (order No. 378 of December 27, 1999) includes classification codes for revenue, expenditures, and domestic and external financing. Although the revenue and expenditure classifications of the compiled GFS are mostly in accordance with the recommendations of the GFSM 1986, the budgetary classification of expenditure, for practical reasons, needs to be identified in terms of units from which data are collected and by function. Thus, there are classifications of expenditures by institution and by function. The accounting records prepared by the Accounting and Reporting Unit in coordination with the Treasury provide an economic classification of expenditures. This economic classification is produced to be sent to the Parliament and for internal purposes, but it is not publicly disseminated.

Classification of revenues comprises the following categories: (a) current revenue; (b) capital revenue; and (c) nonreturnable revenue. ${ }^{21}$ Each of these categories is broken down into groups, each group in types, each type in items, each item in sections, and each section in subsections. The current revenue category includes (a) current tax revenue; (b) social security deductions; and (c) current nontax revenue, and compulsory payments. The capital revenue includes capital nontax revenues and compulsory payments, and the nonreturnable revenue includes current and capital nonreturnable receipts. This classification of revenue is compatible with the GFS classification of revenue. Apart from the inclusion of some fees in the tax category, it is a good basis for classification of data according to GFS concepts.

The expenditure classification by functions includes 22 functional categories. Each of them is broken down in sub-categories. Article 4 of the Law on Budget states that the expenditures are grouped for the distribution of budget appropriations by state agencies and organizations. Thus, the MoF prepares an expenditure classification by institution of approximately 143 public units. The list of public units includes public financial institution, such as the NBRB.

The domestic financing classification consists of the following categories: (a) resources received from the NBRB; (b) resources received from banks and other legal entities and individuals; (c) resources received from other sectors of state administration; (d) other sources of domestic financing; (e) proceeds from sale of property belonging to the state (an item related to the privatization process); (f) foreign exchange transactions; and (g) change in budget balances.

The external financing classification comprises as follows: (a) net credits of international organizations; (b) credits of foreign governments; and (c) other resources of external financing. These categories are broken down into use of credits and repayments.

\footnotetext{
${ }^{21}$ The nonreturnable revenue mainly comprises transfers from international organizations, other levels of state administration, and grants.
} 


\section{$2.4 \quad$ Basis for recording}

\subsubsection{Market prices are used to value flows and stocks}

All cash transactions reflect actual prices. In accordance with the GFSM 1986, debt is recorded at face value (that is, the amount to be repaid at the end of the contract), rather than market value. Also, the amounts denominated in foreign currency are converted to Belarusian rubel at the official exchange rates, as provided by the NBRB.

\subsubsection{Recording is done on an accrual basis}

Revenue and expenditures are recorded on a cash basis for compilation of fiscal data. Additionally, the Accounting and Reporting Unit of the Treasury maintain records of the expenditures in an "actual" basis (proxy for an accrual basis). All financing data, except arrears, are recorded on a cash basis, in line with the GFSM 1986.

\subsubsection{Grossing/netting procedures are broadly consistent with internationally accepted} standards, guidelines, or good practices

Most transactions are shown on a gross basis, in line with the GFSM 1986. Tax refunds are deducted from tax revenue, and financing is presented on a net basis.

\section{Accuracy and reliability}

\subsection{Source data}

\subsubsection{Source data are obtained from comprehensive data collection programs that take into} account country-specific conditions

The main data sources of GFS are the administrative needs for monitoring the budget execution and debt management. These records are maintained in the Treasury, including those recorded by the Accounting and Reporting Unit of the Treasury, for budget execution and domestic financing, and the Debt Management and Financial Analysis System ${ }^{22}$ (controlled by the Department of Finance of External Relations and External Debt) for external financing. The data sources cover detailed financial information on all budgetary units and extrabudgetary funds. These sources also provide information on some stocks and accounting information. The data sources in the MoF concerning the domestic and external debt are shared with the NBRB.

\footnotetext{
${ }^{22}$ This is developed using the software provided by the United Nations.
} 
The Accounting and Reporting Unit has developed a series of reports and formats designed to collect financial information. These reports and formats may be used for the compilation of GFS under the GFSM 2001 analytical framework.

The data sources are kept under continuous review of the reporting process. These reviews are undertaken quarterly and annually by the Treasury. Changes in the presentation of financial information and budget execution are coordinated process as between the reporting and compiling units.

\subsubsection{Source data reasonably approximate the definitions, scope, classifications, valuation, and time of recording required}

The general budget classification for revenue, expenditure, and financing — the data sources - is broadly aligned with the GFSM 1986 definitions, scope, classifications, valuation, and time recording.

\subsubsection{Source data are timely}

Sources of financial information report data in a timely manner. A calendar for reporting is prepared by the Treasury. Data on the execution of Republican budget and extrabudgetary data are available with a 15 days lag after the reference month. Data for local government are available with a 14 days lag after the reference month.

\subsection{Assessment of source data}

\subsubsection{Source data-including censuses, sample surveys and administrative records-are} routinely assessed, for example, for coverage, sample error, response error, and nonsampling error; the results of the assessments are monitored and made available to guide statistical processes

Some verification procedures are in place to assess the accuracy of the budget execution data and some additional resources are planned. There is some of control of the administrative process developed by Treasury staff, such as review and revision of the data reported, and comparison of data reported with indicators prepared for this purpose in the Treasury. The BPFAFD is only a user of this information. The results of these reviews are monitored and made available to guide planning. Generally, there is an appropriate balance between accuracy and timeliness in the production of data. The BPFAFD publishes preliminary data as soon as completed. Preliminary estimates are replaced with final data after audited accounts have been produced. The status of the data used for each period is noted in the GFS publication. 


\subsection{Statistical techniques}

\subsubsection{Data compilation employs sound statistical techniques to deal with data sources}

GFS, including data on local governments, are based on comprehensive information; however, procedures have not been established to allow for estimation of missing data. Budget execution reports are also based on comprehensive information.

3.3.2 Other statistical procedures (for example, data adjustments and transformations, and statistical analysis) employ sound statistical techniques

Generally accepted statistical methods are used to adjust GFS.

\subsection{Assessment and validation of intermediate data and statistical outputs}

\subsubsection{Intermediate results are validated against other information where applicable}

GFS for the central administration are based on the budget data. Intermediate budgetary data are validated against accounting data. Banking statements are daily reconciled against the data prepared in this regard in the MoF. Cross-checking with the NBRB on changes in deposits is performed every year. Also the main statistical output of GFS are validated against other macroeconomic statistics.

\subsubsection{Statistical discrepancies in intermediate data are assessed and investigated}

All discrepancies between GFS and intermediate budgetary data, and those between the intermediate budgetary data and accounting series, are investigated.

3.4.3 Statistical discrepancies and other potential indicators of problems in statistical outputs are investigated

Statistical discrepancies between the deficit/surplus and financing, and between financing and changes in gross debt are investigated and resolved to the extent possible.

\subsection{Revision studies}

3.5.1 Studies and analyses of revisions are carried out routinely and used internally to inform statistical processes (see also 4.3.3)

No revision studies and analyses are prepared. 


\section{Serviceability}

\subsection{Periodicity and timeliness}

\subsubsection{Periodicity follows dissemination standards}

The Republic of Belarus has not adopted the recommendations of the SDDS, which establish that the annually general government aggregates, monthly central government aggregates, and quarterly central government debt should be disseminated. Preliminary statistics for general government operations are disseminated annually and final statistics, monthly. Statistics for consolidated budgetary operations are disseminated annually and monthly. However, periodicity of the data disseminated on the central and general government operations and central government debt exceed SDDS requirements. Work has been initiated for SDDS subscription by the MoF.

\subsubsection{Timeliness follows dissemination standards}

Annual/quarterly statistics for general government operations, monthly statistics for central government budgetary, and quarterly/monthly central government debt are released one month after the end of the reference period. The breakdowns of central government debt are for domestic debt: loans, state bonds, and others; and for external debt: debt of the government, debt guaranteed by the government, and others. Also, external debt by maturity, short-term, medium, and long-term debt are also provided.

\subsection{Consistency}

\subsubsection{Statistics are consistent within the dataset}

For GFS, the various statistical identities, such as deficit/surplus = financing, major aggregates, such as revenue, expenditure, and financing = sum of the components, major aggregates of financing $=$ sum of the domestic and external components, and major aggregates of central budgetary government debt $=$ sum of the components, are observed.

For budget execution data, major aggregates, such as revenue, expenditure, and financing $=$ sum of the components are observed.

\subsubsection{Statistics are consistent or reconcilable over a reasonable period of time}

Fiscal data are consistent with expected trends and reflect discretionary changes, external shocks, and developments of economic activity. Breaks in the time series are identified and documented in the reports attached to the data disseminated through publications of the Minstat and through the fiscal reports posted on the MoF's web site. 


\subsubsection{Statistics are consistent or reconcilable with those obtained through other data sources and/or statistical frameworks}

The overall deficit/surplus and financing present discrepancies owing to a complementary period which are taken into account for the compilation of fiscal data. In this regard, Article 19 of the Law on the Budget System of the Republic of Belarus and State Extrabudgetary Funds states that the accounting period includes the fiscal year and a grace (complementary) period of one month following the end of the reference fiscal year. During this complementary period, the operations on obligations assumed in the execution of the budget of the preceding fiscal year are to be completed. Thus, operations above-the line include payments carried out in January of the following year that belong to the previous fiscal year, meanwhile operations below-the line include payments carried out during the fiscal year from January to December.

Budget execution data of the MoF are the main source for the national accounts estimates for the government sector compiled by the Minstat. There are discrepancies between national accounts and GFS due to differences in data sources and institutional coverage. The national accounts use an accrual basis and include all extrabudgetgary operations.

While efforts are made to reconcile the monetary statistics with the GFS through annual coordination meetings between the NBRB and MoF, improvements in this coordination are needed for a detailed reconciliation of the banking sector transactions in the GFS with the monetary and financial statistics. Currently, changes in the Republican budget and local government budgets are cross-checked with deposits in depositary institutions. Domestic debt is produced by Treasury and is reconciled with the NBRB.

The balance of payments statistics and GFS use the same data source produced by the Department of Finance of External Relations and External Debt in the MoF.

In the consolidation process of the general governments, transfers from the Republican budget to other levels of governments are fully reconciled.

\subsection{Revision policy and practice}

\subsubsection{Revisions follow a regular and transparent schedule}

GFS published for the first time are preliminary, and final data are published following revisions. Generally, revised data are published in the next publication. Revisions are completed when all institutions provide revised data. However, this revision policy is not publicized.

\subsubsection{Preliminary and/or revised data are clearly identified}

Preliminary and final data are adequately noted in publications. Both are disseminated with the same detail and through the same media. 
4.3.3 Studies and analyses of revisions are made public (see also 3.5.1)

No revision studies and analyses are undertaken.

\section{Accessibility}

\subsection{Data accessibility}

5.1.1 Statistics are presented in a way that facilitates proper interpretation and meaningful comparisons (layout and clarity of text, tables, and charts)

Although disseminated aggregates of fiscal data (those that may be used by the MoF for subscription to the SDDS) permit identification and comparison of major aggregates and balancing items, detailed underlying data and time series are not presented. The reports in the MoF's web site do not present the coverage and detail set out in the GFSM 1986, though data are available for extensions in coverage and detail. The presentation of fiscal data is made monthly on the MoF's web site and in nominal terms. This report does not include charts and tables to facilitate analysis and commentaries on current period developments. GFS are not disseminated in the MoF's publications or on its web site.

\subsubsection{Dissemination media and format are adequate}

The Republic of Belarus reports GFS to the IMF for publication in the Government Finance Statistics Yearbook and International Financial Statistics, but these data are not publicly disseminated by the MoF. The main statistical publication of the MoF is a table that will be used for SDDS subscription. The budget data are published by the Minstat in four publications, (a) the Finance of Republic of Belarus, which is published every five years by the Department of Statistics of Finance; (b) the Social Economic Situation in the Republic of Belarus, which is a monthly publication and includes some data analysis, but not publicly disseminated; (c) the Republic of Belarus in Figures, which is a quarterly and annual publication; and (d) the Statistical Yearbook of the Republic of Belarus.

\subsubsection{Statistics are released on a preannounced schedule}

Fiscal data are disseminated according to a preannounced calendar.

\subsubsection{Statistics are made available to all users at the same time}

Fiscal data are available to all users simultaneously. 


\subsubsection{Statistics not routinely disseminated are made available upon request}

Nonpublished, nonconfidential, disaggregated data are made available upon request. The availability of nonpublished data and the terms and conditions under which such data are made available are not publicized.

\subsection{Metadata accessibility}

5.2.1 Documentation on concepts, scope, classifications, basis of recording, data sources, and statistical techniques is available, and differences from internationally accepted standards, guidelines, or good practices are annotated

The concepts, scope, classifications, basis of recording, data sources, and statistical methods for budget data are documented, but only part of this documentation is publicly available. The same documentation is not prepared for GFS. Neither bridge tables showing the links between source data and GFS nor differences from internationally accepted standards are prepared and annotated.

\subsubsection{Levels of detail are adapted to the needs of the intended audience}

GFS metadata are not accessible to the users and detailed budget metadata are not accessible to users.

\subsection{Assistance to users}

\subsubsection{Contact points for each subject field are publicized}

A contact person is identified and the name, email, and telephone number are included on the MoF's web site. The MoF provides support in technical matters to users requesting assistance.

5.3.2 Catalogs of publications, documents, and other services, including information on any changes, are widely available

The MoF's web site presents a list of available publications. 
Table 4. Republic of Belarus: Data Quality Assessment Framework (July 2003): Summary of Results for Government Finance Statistics (Compiling Agency: Minstat)

Key to symbols: $\mathrm{NA}=$ Not Applicable; $\mathrm{O}=$ Practice Observed; $\mathrm{LO}=$ Practice Largely Observed; $\mathrm{LNO}=$ Practice Largely Not Observed; NO = Practice Not Observed; SDDS = Complies with SDDS Criteria

\begin{tabular}{|c|c|c|c|c|c|c|c|}
\hline \multirow{2}{*}{\multicolumn{2}{|c|}{ Element }} & \multirow{2}{*}{ NA } & \multicolumn{4}{|c|}{ Assessment } & \multirow{2}{*}{ Comments } \\
\hline & & & $\mathrm{O}$ & LO & LNO & $\mathrm{NO}$ & \\
\hline $\mathbf{0 .}$ & Prerequisites of quality & & \multirow[b]{5}{*}{$\mathrm{x}$} & & \multirow{5}{*}{$\mathrm{x}$} & & \\
\hline 0.1 & Legal and institutional environment & & & \multirow{4}{*}{$\mathrm{x}$} & & \multirow{4}{*}{ 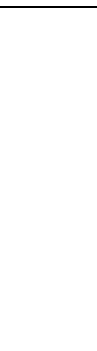 } & $\begin{array}{l}\text { Only an internal provision specifies responsibility for GFS collection and } \\
\text { compilation. Dissemination is limited to the IMF, the Minstat, the NBRB, and } \\
\text { other agencies. Budgetary data provided to the NBRB is not enough for } \\
\text { reconciliation with monetary data. }\end{array}$ \\
\hline 0.2 & Resources & & & & & & $\begin{array}{l}\text { Limited staff resources involved in GFS compilation. Training in the GFSM } \\
2001 \text { is needed. Computer resources require to be updated, and funding needs } \\
\text { to be increased. }\end{array}$ \\
\hline 0.3 & Relevance & & & & & & $\begin{array}{l}\text { User's feedback is not regularly obtained and research to identify new data } \\
\text { requirements is not undertaken. }\end{array}$ \\
\hline 0.4 & Other quality management & & & & & & \\
\hline 1. & \multicolumn{7}{|l|}{ Assurances of integrity } \\
\hline 1.1 & Professionalism & & \multirow[t]{2}{*}{$\mathrm{x}$} & & \multirow{3}{*}{$\mathrm{x}$} & & \multirow{3}{*}{$\begin{array}{l}\text { Terms and conditions under which the MoF collects, compiles, and } \\
\text { disseminates GFS are not available. Access to statistics prior to their release is } \\
\text { not publicly identified. No advance notice is given to the public about major } \\
\text { methodological changes. }\end{array}$} \\
\hline 1.2 & Transparency & & & & & & \\
\hline 1.3 & Ethical standards & & $\mathrm{x}$ & & & & \\
\hline 2. & \multicolumn{7}{|l|}{ Methodological soundness } \\
\hline 2.1 & Concepts and definitions & & \multirow{4}{*}{$\begin{array}{l}\mathrm{x} \\
\mathrm{x}\end{array}$} & $\mathrm{x}$ & \multirow{4}{*}{$\mathrm{x}$} & & \multirow{4}{*}{$\begin{array}{l}\text { A plan to migrate to GFSM } 2001 \text { has not been developed. } \\
\text { Scopes of the compiled GFS and budget system operations are incomplete as . } \\
\text { they do not include all extrabudgetary operations. }\end{array}$} \\
\hline 2.2 & Scope & & & & & & \\
\hline 2.3 & Classification/sectorization & & & & & & \\
\hline 2.4 & Basis for recording & & & & & & \\
\hline 3. & \multicolumn{7}{|l|}{ Accuracy and reliability } \\
\hline 3.1 & Source data & & \multirow{5}{*}{$\begin{array}{l}\mathrm{x} \\
\mathrm{x} \\
\mathrm{x} \\
\mathrm{x}\end{array}$} & & & \multirow[b]{5}{*}{$\mathrm{x}$} & \multirow[b]{5}{*}{ No studies and analysis of revisions are carried out. } \\
\hline 3.2 & Assessment of source data & & & & & & \\
\hline 3.3 & Statistical techniques & & & & & & \\
\hline 3.4 & $\begin{array}{l}\text { Assessment and validation of intermediate data and statistical } \\
\text { outputs }\end{array}$ & & & & & & \\
\hline 3.5 & Revision studies & & & & & & \\
\hline 4. & \multicolumn{7}{|l|}{ Serviceability } \\
\hline 4.1 & Periodicity and timeliness & & \multirow[t]{3}{*}{$\mathrm{x}$} & & & & \multirow{3}{*}{$\begin{array}{l}\text { Comprehensive reconciliation with monetary data is not carried out. } \\
\text { Revision policy and practice are not publicized. }\end{array}$} \\
\hline 4.2 & Consistency & & & $\mathrm{x}$ & & & \\
\hline 4.3 & Revision policy and practice & & & $\mathrm{x}$ & & & \\
\hline 5. & \multicolumn{7}{|l|}{ Accessibility } \\
\hline & Data accessibility & & & $\mathrm{x}$ & & & $\begin{array}{l}\text { Fiscal data are presented in very aggregated formats by the MoF, though by } \\
\text { the Minstat disseminate more disaggregated fiscal data. Some fiscal data are } \\
\text { disseminated on the MoF's web site. No hardcopy publication is produced by } \\
\text { the MoF. }\end{array}$ \\
\hline & Metadata accessibility & & & & $\mathrm{x}$ & & $\begin{array}{l}\text { Metadata for fiscal data are prepared and some is available. Metadata for GFS } \\
\text { are neither prepared nor disseminated. }\end{array}$ \\
\hline 5.3 & Assistance to users & & $\mathrm{x}$ & & & & \\
\hline
\end{tabular}




\section{Monetary Statistics}

\section{Prerequisites of quality}

\section{$0.1 \quad$ Legal and institutional environment}

\subsubsection{The responsibility for collecting, processing, and disseminating the statistics is clearly specified}

The NBRB is the sole official agency in charge of the compilation of monetary statistics in the Republic of Belarus. The NBRB statistical responsibilities are governed by the Banking Code of the Republic of Belarus (Banking Code) of October 2000 and the Statute of the National Bank of the Republic of Belarus of June 2001. In accordance with Article 26 of the Banking Code, the primary functions of the NBRB include the development and implementation, in coordination with the government of the Republic of Belarus, of the monetary policy of the Republic of Belarus. The responsibilities of the NBRB with regard to collecting, processing, and disseminating monetary statistics have not been specifically addressed in the Banking Code or the NBRB Statute. The proposed amendments to the Banking Code, however, which are expected to be enacted during the Spring 2004 session of the National Assembly, ${ }^{23}$ impose on the NBRB the obligation to disseminate to the public aggregated statistical and analytical information on the banking system of the Republic of Belarus.

Within the NBRB, the responsibility for compiling monetary statistics rests with the Money and Credit Statistics Division (MCSD) of the Banking Statistics Department (BSD) of the NBRB. Specific responsibilities of this department and the division with regard to collecting, processing, and disseminating the statistics are regulated by internal instructions of the NBRB.

\subsubsection{Data sharing and coordination among data-producing agencies are adequate}

Statistical inputs for compiling monetary statistics are provided by the Accounting Department of the NBRB and by reporting banks, electronically, to the Computer Systems and Technology Department of the NBRB, where the initial data processing takes place according to established software programs. The processed statistical inputs are subsequently transferred electronically to the BSD for further processing and dissemination. The organization of information flows between departments of the NBRB for purposes of the compilation and dissemination of monetary statistics is regulated by NBRB internal instructions and is adequate.

\footnotetext{
${ }^{23}$ These amendments were approved by the National Assembly in first reading on April 9, 2004.
} 
Data sharing and coordination with other data producing agencies are based on the provisions of the Banking Code. Article 36 states that government agencies and the NBRB shall furnish each other, in a mutually agreed manner, statistical, analytical, and operational information that is required for proper performance of their functions. A written agreement between the NBRB and the Minstat regulates their statistical collaboration. In addition, in preparing and disseminating data with regard to possible subscription to the SDDS, the NBRB also coordinates with the MoF. There is smooth informal cooperation among data producing agencies at the working level, and formal meetings are held between the various agencies when necessary.

\subsubsection{Individual reporters' data are to be kept confidential and used for statistical purposes only}

The confidentiality of individual reporters' data is regulated by Article 122 of the Banking Code on bank secrecy. According to this article, information on accounts and deposits of bank clients is subject to bank secrecy and may not be disclosed. Staff members of the NBRB and other banks are required to observe bank secrecy, and ensure confidentiality of information acquired in performance of their duties.

Monetary statistics are produced mainly from balance sheet data provided by the commercial banks and other banking institutions in their monthly returns. Only the staff of the MCSD have access to data of individual banks before these data are aggregated and consolidated for publication.

\subsubsection{Statistical reporting is ensured through legal mandate and/or measures to encourage response}

The NBRB's legal mandate with regard to statistical reporting is adequate. Article 34 of the Banking Code grants the NBRB the right to request from banks and nonbank credit and financial institutions information on all matters relating to their activity. In accordance with Article 37 of the Banking Code, banks and nonbank credit and financial institutions operating within the Republic of Belarus are obliged to furnish financial and economic information and documentation to the NBRB in the manner prescribed by the NBRB. Furthermore, on the basis of Article 120 of the Banking Code, banks are required to submit reports on their activity to the NBRB in the form, manner, and at the times prescribed by the NBRB.

\section{$0.2 \quad$ Resources}

\subsubsection{Staff, facilities, computing resources, and financing are commensurate with statistical programs}

The BSD has 14 professional staff members, five of which are directly involved in compiling monetary statistics in the MCSD, and three are dealing with editorial and dissemination activities at the departmental level. All MCSD staff have college degrees, either in economics or in economics and mathematics, with a capability in computer programming. 
The professional qualifications of staff involved in producing monetary statistics are further developed through various training opportunities, including courses provided by the IMF at the Joint Vienna Institute and, in cooperation with the Central Bank of Russia, at the training center in Tula. All except one staff member of the MCSD have participated in those courses. The NBRB's salary levels are the same as those of the top group of government agencies and favorably compare with those of the commercial banks (up to the mid-level of management). Therefore, excessive staff turnover is not a particular problem.

A recent law has brought the status of NBRB staff at the same level of other civil servants. This law resulted in a dramatic decrease in the managers' ability to reward employees based on their performance. Whereas the bonus system in place, according to the previous staff regulation, allowed bonuses for up to 100 percent of the basic salary; the current threshold is now about 35 percent. The NBRB is experiencing serious difficulty to retain qualified employees, in particular junior professionals. There are clear indications that the NBRB ranks within the domestic banking sector in terms of salary and benefits provided to its employees. This causes a certain concern among NBRB's managers.

While present staff resources appear to be adequate for compiling monetary statistics, there are some concerns because of the "mission creep," whereby the MCSD's responsibilities are expanded to include, in addition to monetary statistics produced in accordance with international standards, various other statistical data. At present, over 150 other statistical presentations and data sets are regularly produced by the MCSD. Most recently, this division has been charged with the task of developing methodology and compiling data on the gross value added in the banking sector. In light of the present workload, and taking into account the need to implement during 2004 the new Standardized Report Form that is being developed by the IMF, there is a need for a careful review by the management of the NBRB of present statistical activities performed by the MCSD with a view to either reducing the scope of these activities or increasing staff resources assigned to these activities.

Computer resources available for the preparation of monetary and financial statistics are adequate. Hardware is appropriately allocated to ensure effective data processing and database management. Each staff member has his/her own computer, is connected to the network, and units have access to the Internet. Software resources are adequate and periodically modernized. The reporting from banks is based on a specialized program PROCarry, and individual staff apply either Lotus 5 or Excel in their data work.

\subsubsection{Measures to ensure efficient use of resources are implemented}

Effective use of staff resources is promoted, among other measures, through annual individual performance assessment discussions with staff members. Statistical compilers employ modern data processing techniques. The process of collecting and processing statistics is computerized and highly automated, which permits the compilation of analytical accounts of the monetary authorities on a daily basis, and analytical accounts of deposit money banks and the monetary survey on a weekly basis. As mentioned under 0.2.1 above, there appears to be a need for a review of the rationale for producing the additional data sets 
by the MCSD, with a view to streamlining its statistical activities and finding additional efficiencies.

\section{$0.3 \quad$ Relevance}

0.3.1 The relevance and practical utility of existing statistics in meeting users' needs are monitored

The NBRB conducts quarterly meetings on the directions of money and credit policy, in which official users of monetary statistics have an opportunity to provide feedback on the level of detail, periodicity, and timeliness of data. Although formal user surveys are not conducted, feedback from users is actively sought through providing a contact person and phone number in the NBRB's Bulletin of Banking Statistics and on the NBRB's web site (including email address of the contact person). Data presentation formats are occasionally modified in response to users' requests.

\subsection{Other quality management}

\subsubsection{Processes are in place to focus on quality}

The NBRB recognizes that official statistics must have the confidence of their users. The NBRB management and senior staff concentrate on compliance with the key parameters of quality of statistical information such as integrity, methodological soundness, accuracy and reliability, serviceability, and accessibility as integral part of compiling monetary statistics.

Procedures are in place that verify information at each stage of the collection, processing, and dissemination of data. The Computer Systems and Technology Department carries out preliminary consistency checks on statistical inputs, and the BSD works with the Accounting Department, the Balance of Payments Department, and other NBRB departments and units to conduct data reconciliation. Financial statements of the NBRB and commercial banks are audited by external audit companies.

\subsubsection{Processes are in place to monitor the quality of the statistical program}

Quality control in the process of collecting, processing, and verifying data is performed through cross-checks and, in the event of discrepancies, through follow-ups by staff of the MCSD with the Accounting Department, the Balance of Payments Department, and the reporting banks. Validation procedures for assessing the plausibility or reasonableness of reported data are undertaken visually on a bank-by-bank basis. Particular care is taken to ensure consistency of time series, whereby, in the event of data revisions, data for the past periods are revised accordingly.

There is no other body outside the NBRB that provides regular guidance on the quality of monetary statistics, and on strategies for improving data production; however, recommendations from international organizations are actively sought and used to improve 
quality of monetary statistics. Suggestions on improvements of monetary data and their publication are provided ad-hoc by users of monetary statistics.

\subsubsection{Processes are in place to deal with quality considerations in planning the statistical program}

Quality issues are taken into account in the work program planning process. Improvements identified through ongoing monitoring, feedback from users, and recommendations from international organizations are incorporated in the work program for implementation whenever feasible. Because of the very high periodicity of monetary statistics, timeliness of data production is a matter of primary attention, with due regard, however, to accuracy/reliability and other dimensions of data quality. As the production of monetary data is to a great extent automated, improvements in data quality are primarily sought through improvements in the source data used for compiling monetary statistics. As a result, it has been possible to adhere to a strict publication schedule, without compromising the quality of the data. Although the statistics produced are aggregates, the data compilation system permits the direct tracing of all aggregates to individual accounts of the NBRB and to those of the commercial banks.

\section{Assurances of integrity}

\section{$1.1 \quad$ Professionalism}

\subsubsection{Statistics are produced on an impartial basis}

The statutory provisions under which the NBRB compiles monetary statistics are adequate to support its impartiality in conducting these functions. In accordance with paragraph 22 of the NBRB Statute, governmental authorities have no right to interfere in the activities of the NBRB conducted within its authority. Staff involved in compiling monetary statistics enjoy professional independence, within usual limits imposed by the hierarchical administrative structure of the central bank. Professional competency plays a key role in recruitment and promotion policy in the BSD. Staff involved in producing monetary statistics is given opportunities to enhance their professionalism through participation in external courses and on-the-job training.

\subsubsection{Choices of sources and statistical techniques as well as decisions about dissemination are informed solely by statistical considerations}

The choice of sources and statistical methods is determined solely by statistical considerations. The NBRB staff take steps to ensure that data sources, instruments, and methodology used in the preparation of monetary statistics are consistent with those in other areas of macroeconomic statistics (national accounts, balance of payments, GFS, and international investment position). 


\subsubsection{The appropriate statistical entity is entitled to comment on erroneous interpretation and misuse of statistics}

The NBRB's spokesperson is authorized to provide comments on all matters referring to the NBRB's activities, including its statistical functions. The BSD actively monitors the use and interpretation of monetary statistics in the financial press and mass media. Cases of data misinterpretation or misuse are brought to the attention of the NBRB's spokesperson for further handling. The NBRB seeks to prevent misinterpretation or misuse of monetary statistics by providing the metadata and explanatory methodological notes on its web site and in its publications.

\subsection{Transparency}

\subsubsection{The terms and conditions under which statistics are collected, processed, and disseminated are available to the public}

The Banking Code and the NBRB Statute are publicly available and are posted (in Russian and in English) on the NBRB's web site. A data release calendar and the description of methodology underlying monetary statistics compiled by the NBRB are published in the NBRB's Bulletin of Banking Statistics and are also posted on the NBRB's web site.

\subsubsection{Internal governmental access to statistics prior to their release is publicly identified}

No access is provided to statistical data prior to their release. A publicly available statement on this data dissemination policy is available on the NBRB's web site, as a part of monetary statistics metadata.

\subsubsection{Products of statistical agencies/units are clearly identified as such}

A note included in the Bulletin of Banking Statistics clearly identifies the BSD of the NBRB as the producer of data. Similar note is posted in the statistical section of the NBRB's web site. The agreement on information sharing between the NBRB and the Minstat stipulates a mandatory procedure for referencing the data source when using data provided to the NBRB by the Minstat, and vice versa.

\subsubsection{Advanced notice is given of major changes in methodology, source data, and statistical techniques}

Advance notice is given in the Bulletin of Banking Statistics in cases of major changes in the methodology, including the introduction of new charts of accounts. Reasons for adjustments in time series data are explained in comments to corresponding tables in the Bulletin of Banking Statistics. 


\subsection{Ethical standards}

\subsubsection{Guidelines for staff behavior are in place and are well known to the staff}

A Code of Professional Ethics of the Employee of the NBRB was introduced in April 2003. Each employee is required to know and follow this code. Copies of the code are easily available to the NBRB staff.

\section{Methodological soundness}

\subsection{Concepts and definitions}

\subsubsection{The overall structure in terms of concepts and definitions follows internationally accepted standards, guidelines, or good practices}

The analytical framework used for compiling monetary statistics reflects concepts and definitions that are, in general, consistent with the Monetary and Financial Statistics Manual (MFSM). The balance sheets of the NBRB and commercial banks, which underlie the monetary statistics, broadly follow international accounting standards.

The accounts of the central bank are compiled and disseminated on the basis of the monetary authorities concept, in which the central bank's balance sheet data are augmented to include government positions with the IMF. This approach puts the NBRB's data at par with those countries, in which central banks' balance sheets include all positions with the IMF.

Major aggregates of the broad money survey compiled by the NBRB are as follows:

- net foreign assets of depository corporations, disaggregated into gross claims on and liabilities to nonresidents in convertible currencies and gross claims on and liabilities to nonresidents in nonconvertible currencies;

- net domestic credit, disaggregated into net credit to general government (further disaggregated into claims on and liabilities to central government in national and foreign currencies, and claims on and liabilities to local governments in national and foreign currencies), claims on public nonfinancial corporations, claims on private sector, and claims on nonbank financial institutions;

- $\quad$ other domestic assets (net), disaggregated into capital accounts and other assets (net); and

- broad money, disaggregated into currency outside banks, transferable deposits, time deposits, foreign currency deposits, and securities included in broad money in national and foreign currencies. 
Separate data on monetary authorities' accounts and those of other depository corporations are also disseminated, as well as a number of more detailed breakdowns, including loans by sector, currency, and maturity; and nonperforming loans by sector, currency, and maturity.

The following monetary aggregates are derived from the broad money survey: currency outside banks (M0); narrow money (M1), comprising M0 plus transferable deposits in rubel; money supply according to national definition (M2), comprising M1 plus time deposits in rubels; rubel money supply (M2*), comprising M2 plus securities other than shares in rubels issued by banks; and broad money (M3), comprising M2* plus foreign currency transferable and time deposits, securities in foreign currency issued by banks, and deposits in precious metals of residents.

\section{$2.2 \quad$ Scope}

\subsubsection{The scope is broadly consistent with internationally accepted standards, guidelines, or good practices}

The institutional coverage of monetary statistics includes monetary authorities (NBRB accounts augmented by government positions with the IMF), 30 operating commercial banks, and three banks in the process of liquidation. Data for the NBRB consolidate balance sheets of its headquarters and six provincial branches, and the data for the commercial banks consolidate the accounts of their headquarters and 469 branches. At present, there are no nonbank depository corporations in the Republic of Belarus. Thus, the scope of monetary statistics compiled by the NBRB covers all depository corporations (financial corporations whose liabilities are included in the national definition of broad money) resident in the Republic of Belarus and is, therefore, consistent with the guidelines of the MFSM.

No data are collected on the operations of nondepository financial corporations, including insurance companies, investment funds, other financial intermediaries, and financial auxiliaries. A financial corporations' survey, consolidating the accounts of the entire financial corporations sector, is, therefore, not compiled.

\subsection{Classification/sectorization}

\subsubsection{Classification/sectorization systems used are broadly consistent with internationally accepted standards, guidelines, or good practices}

The principles of sectorization applied in the monetary statistics compiled by the NBRB are satisfactorily consistent with the IMF's MFSM, which recommends distinguishing between resident and nonresident units on the basis of the concept of "center of economic interest" and classifying resident institutional units into domestic sectors according to their objectives, functions, and economic behavior. The sectoral classification of resident units recommended in the MFSM for the purpose of compiling monetary statistics refers mainly to the subsectors distinguished in the 1993 SNA and is as follows: (a) central bank; (b) other depository corporations; (c) other financial corporations; (d) central government; (e) state and local 
governments; (f) public nonfinancial corporations; (g) other nonfinancial corporations; and (h) other resident sectors.

In the monetary statistics compiled by the NBRB, the following sectoral groupings of resident institutional units are distinguished: (a) monetary authorities; (b) commercial banks; (c) nonbank financial institutions; (d) central government; (e) local governments; (f) public commercial enterprises $^{24}$; and $(\mathrm{g})$ private sector. Notwithstanding certain differences in naming convention, this sectoral classification can be easily reconciled with the guidelines of the MFSM. The accounting records supporting the production of the monetary statistics contain sufficient detail to cover the complete classification of financial instruments, as categorized in the MFSM. Consistently with the MFSM recommendations, deposits in financial corporations that are closed pending liquidation or reorganization are considered as restricted deposits and are excluded from money aggregates.

In accordance with the MFSM, the distinction of nonresident units is based on the concept of the center of economic interest. There are no branches of foreign banks operating in the Republic of Belarus, and no Belarusian banks have branches abroad.

The principles underlying the classification of financial instruments are based on international standards and are generally consistent with the MFSM guidelines. The classification framework is based on the liquidity of the financial instruments and the legal characteristics that describe the form of the underlying creditor/debtor relationship. Beginning from January 2004, the treatment of the securities repurchase agreements (repos) has been changed in line with the MFSM guidelines; securities repurchase agreements are classified as collateralized loans, rather than as outright sales of securities. However, contrary to the MFSM standard, financial derivatives are considered as off-balance sheet items and are, therefore, excluded from monetary statistics.

\subsection{Basis for recording}

\subsubsection{Market prices are used to value flows and stocks}

The general recommendation of the MFSM is that the valuation of financial assets and liabilities should be based on market prices or, for financial assets and liabilities that are not traded or traded infrequently, on market-price equivalents (fair values). The valuation of loans is an exception to this principle, and loan values should be based on creditors' outstanding claims without adjustment for expected loan losses. This amount comprises the outstanding principal plus any accrued interest and is referred to as the book value of a loan.

\footnotetext{
${ }^{24}$ In classifying enterprises as public or private, banks rely on the statistical registration of enterprises at the Minstat. Therefore, any issues raised in section I, National Accounts, with regard to the classification of enterprises in the registry, apply to monetary statistics.
} 
Valuation principles used by the NBRB in compiling monetary statistics are broadly consistent with these recommendations. Loans are valued at book value and include the outstanding principal and interest accruals. Provisions for loan losses are not netted out from the gross value of loans, but are recorded as other liabilities, which is consistent with the treatment recommended in the MFSM. Securities are valued at the acquisition cost plus accrued interest, which may be considered an acceptable approximation of the fair market value. One important departure from the valuation rules recommended in the MFSM applies to monetary gold, which is recorded in the NBRB's account at the historic acquisition cost (transaction cost) and is revalued at irregular intervals, as authorized by individual directives of the management of the NBRB. The most recent revaluation of monetary gold was as of January 1,1999 . This historic cost valuation of gold is at present also applied in monetary statistics produced by the NBRB, however, a decision has already been taken to revalue gold at market prices in monetary statistics beginning with data for April 2004, and to revise historic time series accordingly.

In accordance with the MFSM, positions denominated in foreign currencies should be converted into national currency equivalents on the basis of end-of period mid-point market exchange rates. The accounting procedures applied in the Republic of Belarus's monetary statistics are consistent with these provisions. Assets and liabilities denominated in foreign currencies are revalued on a daily basis at the official exchange rates established by the NBRB, which is a mid-point rate of the closing of the inter-bank market of the previous day. Positions with the IMF are converted into rubel equivalents using the end-of-period SDR/US dollar exchange rate provided by the IMF and the NBRB's rubel/US dollar exchange rate.

\subsubsection{Recording is done on an accrual basis}

In accordance with the MFSM, transactions should be recorded on an accrual basis, that is, at the time economic value is created, transformed, exchanged, or extinguished. Interest should be recorded as a financial transaction that occurs continuously during the accounting period and represents an increase in the amount of the underlying asset or liability. The accounting rules applied in Belarusian monetary statistics are consistent with these guidelines. Transactions are recorded simultaneously between parties, and accrued interest on deposits, loans, and securities is incorporated into the outstanding amount of the financial asset or liability, rather than being treated as part of other accounts receivable/payable.

The analytical framework for monetary statistics recommended in the MFSM comprises a complete set of accounts, in which opening and closing stocks of assets and liabilities are linked to each other through recording of economic flows (transactions, revaluations, and other changes in the volume of assets). As is the case in most other countries, the NBRB does not yet compile data on flows, although flow data on loans extended by banks and repayments received, classified by sector are disseminated. 


\subsubsection{Grossing/netting procedures are broadly consistent with internationally accepted standards, guidelines, or good practices}

The general guideline of the MFSM is that data should be collected and compiled on a gross basis, without netting claims on particular transactors against liabilities to those transactors. Netting is to be applied only to some data categories in analytical surveys, whereby the underlying data on a gross basis should also be shown. The monetary statistics compiled by the NBRB conform to these guidelines. Data are derived automatically by the existing computer program from detailed accounting balance sheets of the NBRB and commercial banks. All accounts of the NBRB and commercial banks are first reorganized in appropriate analytical groupings (Stage 1), followed by an aggregation into detailed surveys for the NBRB and the commercial banks (Stage 2), and consolidated into aggregated surveys of the monetary authorities and commercial banks (Stage 3). Similarly, a detailed and aggregated broad money survey is automatically derived from the data compiled in Stage 2.

The data in the detailed analytical balance sheets derived in Stage 1 are not subject to any consolidation or netting adjustments. To permit easy checking of the consistency between the accounting and the analytical balance sheets, the compilation procedure requires that the total assets/liabilities in the corresponding balance sheets are the same. The derivation of the detailed surveys in Stage 2 involves compiling several aggregates on a net basis (net foreign assets, net claims on central government, net claims on banks, net claims on the NBRB, and other items net); however, gross claims and liabilities that underlie these net aggregates are also provided. Only the aggregated surveys compiled in Stage 3 do not provide the gross components of the items subject to netting and consolidation.

\section{Accuracy and reliability}

\subsection{Source data}

\subsubsection{Source data are obtained from comprehensive data collection programs that take into account country-specific conditions}

The NBRB maintains a comprehensive and complete register of depository corporations. The institutional and geographic coverage of this register is complete. Other (nondepository) financial corporations are not included. Data included in the broad money survey for the NBRB are based on the detailed daily accounting balance sheet compiled by the NBRB's Accounting Department. This balance sheet covers all accounts of the NBRB. Data for the commercial banks are compiled from a detailed consolidated balance sheet of the commercial banks that is provided by the NBRB's Computer Systems and Technology Department. In cases when the balance sheet used for compiling monetary statistics do not provide all details necessary to classify data by financial instrument and sector, supplementary information is collected. For example, such supplementary information is routinely collected from commercial banks to permit more accurate sectoral classification of deposits and to permit the breakdown between public and private enterprises. Thus, all data are derived from administrative sources and the statistical data estimation techniques are not used. Data on 
positions with the IMF are initially included in the broad money survey on the basis of NBRB's rubel/SDR exchange rate, but are subject to subsequent revision on the basis of monthly information from the Statistics Department of the IMF.

\subsubsection{Source data reasonably approximate the definitions, scope, classifications, valuation, and time of recording required}

Source data used for compiling monetary statistics provide a reasonably good approximation of the concepts, definitions, scope, classifications, and recording principles for compiling sound monetary statistics that are recommended in the MFSM. There are only few deficiencies of the source data, and these are carried forward to statistical outputs. These deficiencies refer to the valuation of gold at historic acquisition cost rather than at end-ofperiod market prices, and to the exclusion of financial derivatives as off-balance sheet items.

\subsubsection{Source data are timely}

Daily data on the NBRB's balance sheet items are provided on the next day, and the commercial banks' balance sheet data are provided to the NBRB on a weekly basis within three working days (supplementary information from commercial banks is available within four working days). This timeliness of the source data permits the dissemination of monetary statistics well within the SDDS requirements. As the IMF data on the positions with the IMF and the SDR/rubel exchange rate are available with a lag of about three weeks, the NBRB adopted a practice of publishing preliminary data for the most recent month within two weeks after the end of period, and revising these data using the inputs from the IMF in the next month.

\subsection{Assessment of source data}

3.2.1 Source data-including censuses, sample surveys and administrative records-are routinely assessed, for example, for coverage, sample error, response error, and nonsampling error; the results of the assessments are monitored and made available to guide statistical processes

Given that the compilation of monetary statistics is based on a direct and mostly automatic transformation of administrative (accounting) source data, compilers of monetary statistics routinely assess source data and initiate their modifications if needed for improvements in statistical outputs. This refers mostly to changes in charts of accounts for the NBRB and commercial banks, and to valuation principles applied in accounting.

The accuracy of source data is tested through a system of formal consistency checks and, when needed, out-of-trend values are verified in direct contacts with reporting banks. 


\subsection{Statistical techniques}

\subsubsection{Data compilation employs sound statistical techniques to deal with data sources}

The statistical techniques used to compile monetary statistics are to a great extent automated and minimize processing time and errors (for example, coding, editing, and tabulating errors). The adjustments for nonresponse are not an issue, because all reporting banks routinely comply with the reporting requirement.

3.3.2 Other statistical procedures (for example, data adjustments and transformations, and statistical analysis) employ sound statistical techniques

The compilation of monetary statistics is fully based on administrative sources and statistical adjustments are not carried out. A possibility of carrying out statistical adjustments to revalue monetary gold at market prices is at present under consideration. No seasonal adjustments to monetary aggregates are at present carried out.

\subsection{Assessment and validation of intermediate data and statistical outputs}

\subsubsection{Intermediate results are validated against other information where applicable}

Intermediate results are routinely validated against any other reports available to the MCSD, the Balance of Payments Department, and other departments of the NBRB.

\subsubsection{Statistical discrepancies in intermediate data are assessed and investigated}

Intermediate data are analyzed for internal and intertemporal consistency

\subsubsection{Statistical discrepancies and other potential indicators of problems in statistical outputs are investigated}

Any inconsistencies and unexplained large data variations are investigated in direct contacts with the reporting banks.

\subsection{Revision studies}

3.5.1 Studies and analyses of revisions are carried out routinely and used internally to inform statistical processes (see also 4.3.3)

Revisions to the monetary statistics are periodically assessed and preliminary data are compared with final results to assess the direction and magnitude of revisions. Monthly revisions that result from a difference between the NBRB's and the IMF's exchange rates of rubel to SDRs are insignificant. Similarly, the revision of the end-of-year data following the audit of the NBRB's annual balance sheet, did not result in statistically significant data changes. 


\section{Serviceability}

\subsection{Periodicity and timeliness}

\subsubsection{Periodicity follows dissemination standards}

Monetary statistics compiled by the NBRB comply fully with the periodicity requirements of the SDDS, which prescribes dissemination of monthly data on the analytical accounts of the central bank and the analytical accounts of the banking sector.

\subsubsection{Timeliness follows dissemination standards}

Both the monetary authorities accounts and the banking sector accounts are disseminated by the NBRB with a lag of two weeks after the end of the accounting period, which meets orfor the analytical accounts of the banking sector-exceeds the timeliness prescribed in the SDDS (two weeks and one month, respectively).

\subsection{Consistency}

\subsubsection{Statistics are consistent within the dataset}

Monetary statistics are reasonably consistent within the datasets. The discrepancies between net reciprocal claims and liabilities of the NBRB and commercial banks do not exceed for the last 15 months 1.3 percent of the broad money, which is an acceptable degree of inconsistency in view of the usual timing differences in settling accounts.

\subsubsection{Statistics are consistent or reconcilable over a reasonable period of time}

The NBRB's compilers take due care to ensure intertemporal data consistency. In the case of classification changes, data for the past periods are revised accordingly as far back as possible. For example, after a recent discovery of a misclassification of credits granted by commercial banks to local governments, relevant data were revised beginning from November 2002, when such credits were extended for the first time. As a result, monetary statistics time series are reasonably consistent and are available on the NBRB's web site since 2000. Work is being carried out to post time series since 1996 on the NBRB's web site.

\subsubsection{Statistics are consistent or reconcilable with those obtained through other data sources and/or statistical frameworks}

Monetary data are consistent with the balance of payments and international investment position data, in particular because the same source data on the banking sector's foreign assets and liabilities are used. Owing to methodological differences, however, there are some differences in final statistical outputs. For example, monetary gold in balance of payments statistics is valued at end-of-period market prices, while in monetary statistics, as noted in section 2.4.1 and contrary to MFSM guidelines, historic acquisition cost valuation is used. 
The consistency of monetary data with government finance data is routinely monitored by the NBRB and the MoF data on financing from monetary authorities are cross-checked against the NBRB's data on balances in central government accounts. However, no comprehensive reconciliation of the differences between monetary and fiscal data is carried out, even though monetary data on the changes in commercial banks' net claims on central government differ very significantly from fiscal data on the central government financing from the commercial banks.

\subsection{Revision policy and practice}

\subsubsection{Revisions follow a regular and transparent schedule}

Monthly data are considered preliminary and subject to revisions during one quarter after publication and end-of-year data during six month after publication. This data revision policy is publicized on the NBRB's web site.

\subsubsection{Preliminary and/or revised data are clearly identified}

Neither the end-of-year data that are subject to revision following the audit of the NBRB's annual balance sheet, nor the data for the most recent month that are subject to revision after the receipt of the IMF inputs, are clearly marked as provisional. Analogically, the revised data are not marked as such in the NBRB's publications.

\subsubsection{Studies and analyses of revisions are made public (see also 3.5.1)}

Given that both monthly and annual data revisions do not result in statistically significant data changes, no formal revision studies are disseminated to the public. Explanatory notes on the reasons for revisions are provided in footnotes to disseminated tables.

\section{Accessibility}

\subsection{Data accessibility}

\subsubsection{Statistics are presented in a way that facilitates proper interpretation and meaningful comparisons (layout and clarity of text, tables, and charts)}

The presentation of monetary statistics by the NBRB facilitates the interpretation of the data by the users. The central bank's and the commercial bank's accounts are presented in a balance sheet format. The NBRB's web site provides users with considerable opportunities for viewing the data, metadata, explanatory notes on the data, calendar for the dissemination of preliminary data, and other information. The web site features user-friendly tables with the key indicators of monetary statistics. Similarly, the publication of monetary data in the Bulletin of Banking Statistics contains both aggregated and detailed tables and provides time series for the most recent two years. 


\subsubsection{Dissemination media and format are adequate}

Monetary data are disseminated in hard copy in the monthly Bulletin of Banking Statistics and in the bi-weekly Banking Magazine (Bankauski Vesnik) in Russian, while the English language edition of the Bulletin of Banking Statistics is available on a quarterly basis, owing to limited translation resources. Also, downloadable monetary data in Excel are posted on the NBRB's web site in Russian and in English.

\subsubsection{Statistics are released on a preannounced schedule}

An advance release calendar is published in the Bulletin of Banking Statistics and is posted on the NBRB's web site. Data are released in accordance with the schedule announced in that calendar.

\subsubsection{Statistics are made available to all users at the same time}

Access to monetary statistics is provided simultaneously to all users, ministries, and agencies through postings on the NBRB's web site and in hard copy publications, that is, Bulletin of Banking Statistics, which are released simultaneously. This policy is publicized on the NBRB's web site.

\subsubsection{Statistics not routinely disseminated are made available upon request}

Unpublished and nonconfidential data are made available free of charge upon request. This policy is publicized on the NBRB's web site.

\subsection{Metadata accessibility}

5.2.1 Documentation on concepts, scope, classifications, basis of recording, data sources, and statistical techniques is available, and differences from internationally accepted standards, guidelines, or good practices are annotated

The NBRB disseminates methodological commentary in each issue of the Bulletin of Banking Statistics and on its web site. The commentary provides information on concepts, definitions, classifications, and data sources. In addition, metadata for monetary statistics, in the format adopted in SDDS, are posted on the NBRB's web site in Russian. Metadata include information about the scope, periodicity, timeliness, accessibility, and reliability. Information provided in these sources on accounting rules and the basis for recording needs to be expanded. 


\subsubsection{Levels of detail are adapted to the needs of the intended audience}

The methodological commentary provided in the Bulletin of Banking Statistics contains a much more detailed description of concepts and definitions than that in the SDDS metadata that are posted on the NBRB's web site.

\subsection{Assistance to users}

\subsubsection{Contact points for each subject field are publicized}

The name and phone number for contact person is provided in the Bulletin of Banking Statistics. In addition, metadata posted on the NBRB's web site provides the name, phone and fax numbers, and email address of the contact person for each data set.

\subsubsection{Catalogs of publications, documents, and other services, including information on} any charges, are widely available

A list of NBRB's publications is disseminated in the December issue of the Banking Magazine and is also available on the web site. The NBRB's web site provides users with considerable amount of information about electronic and paper-based publications and documents. The terms of subscription for the printed versions of the Bulletin of Banking Statistics and Banking Magazine are not publicized, but they can be obtained at the contact telephone numbers and addresses indicated in each issue of these publications. 
Table 5. Republic of Belarus: Data Quality Assessment Framework (July 2003): Summary of Results for Monetary Statistics (Compiling Agency: National Bank of the Republic of Belarus)

\begin{tabular}{|c|c|c|c|c|c|c|c|}
\hline \multirow{2}{*}{\multicolumn{2}{|c|}{ Element }} & \multirow{2}{*}{ NA } & \multicolumn{4}{|c|}{ Assessment } & \multirow{2}{*}{ Comments } \\
\hline & & & $\mathrm{O}$ & LO & LNO & $\mathrm{NO}$ & \\
\hline 0. & \multicolumn{7}{|l|}{ Prerequisites of quality } \\
\hline 0.1 & Legal and institutional environment & & $\mathrm{x}$ & & & & \\
\hline 0.2 & Resources & & $\mathrm{x}$ & & & & \\
\hline 0.3 & Relevance & & $\mathrm{x}$ & & & & \\
\hline 0.4 & Other quality management & & $\mathrm{x}$ & & & & \\
\hline 1. & \multicolumn{7}{|l|}{ Assurances of integrity } \\
\hline 1.1 & Professionalism & & $\mathrm{x}$ & & & & \\
\hline 1.2 & Transparency & & $\mathrm{x}$ & & & & \\
\hline 1.3 & Ethical standards & & $\mathrm{x}$ & & & & \\
\hline 2. & \multicolumn{7}{|l|}{ Methodological soundness } \\
\hline 2.1 & Concepts and definitions & & $\mathrm{x}$ & \multirow{4}{*}{$\begin{array}{l}\mathrm{x} \\
\mathrm{x}\end{array}$} & & & \multirow{4}{*}{$\begin{array}{l}\text { Financial derivatives are not included in monetary statistics (off-balance sheet) } \\
\text { Monetary gold is not valued at market prices. }\end{array}$} \\
\hline 2.2 & Scope & & $\mathrm{x}$ & & & & \\
\hline 2.3 & Classification/sectorization & & & & & & \\
\hline & Basis for recording & & & & & & \\
\hline 3. & \multicolumn{7}{|l|}{ Accuracy and reliability } \\
\hline 3.1 & Source data & & $\mathrm{x}$ & & & & \\
\hline 3.2 & Assessment of source data & & $\mathrm{x}$ & & & & \\
\hline 3.3 & Statistical techniques & & $\mathrm{x}$ & & & & \\
\hline & $\begin{array}{l}\text { Assessment and validation of intermediate data and statistical } \\
\text { outputs }\end{array}$ & & $\mathrm{x}$ & & & & \\
\hline 3.5 & Revision studies & & $\mathrm{x}$ & & & & \\
\hline 4. & \multicolumn{7}{|l|}{ Serviceability } \\
\hline & Periodicity and timeliness & & $\mathrm{x}$ & \multirow{3}{*}{$\mathrm{x}$} & \multirow[b]{3}{*}{$\mathrm{x}$} & & \multirow{3}{*}{$\begin{array}{l}\text { Full reconciliation with GFS data not carried out. } \\
\text { Preliminary and revised data are not clearly identified; revision studies are not } \\
\text { publicized. }\end{array}$} \\
\hline & Consistency & & & & & & \\
\hline & Revision policy and practice & & & & & & \\
\hline 5. & \multicolumn{7}{|l|}{ Accessibility } \\
\hline & Data accessibility & & $\mathrm{x}$ & & & & \\
\hline & Metadata accessibility & & $\mathrm{x}$ & & & & \\
\hline 5.3 & Assistance to users & & $\mathrm{x}$ & & & & \\
\hline
\end{tabular}




\section{Balance of Payment Statistics}

\section{Prerequisites of quality}

\section{$0.1 \quad$ Legal and institutional environment}

\subsubsection{The responsibility for collecting, processing, and disseminating the statistics is clearly specified}

The responsibility for collecting and compiling balance of payments statistics is clearly specified in Article 12 of the Statute of the NBRB, approved on June 13, 2001 by edict number 320 of the President of the Republic of Belarus. According to article 12, the NBRB "...participate in forecasting the balance of payments and arrange for the compilation of the balance of payments for the Republic of Belarus."

The NBRB's role in collecting and compiling balance of payments statistics is also confirmed in the Banking Code of the Republic of Belarus passed by the House of Representatives on October 3, 2000, and approved by the Council of the Republic on October 13, 2000. Article 26 specifies the functions of the NBRB, including participating in forecasting the balance of payments and arranging for the compilation of the balance of payments for the Republic of Belarus.

A legal framework establishing the NBRB's (or other national agencies') responsibility to disseminate balance of payments statistics is not clearly defined. However, there is clear provision establishing the NBRB's obligation to provide information on request. Article 34 of the Constitution of the Republic of Belarus, which includes NBRB's obligation to provide data, (adopted on March 15, 1994) specifies that "...citizens of the Republic of Belarus shall be guaranteed the right to receive, store, and disseminate complete, reliable, and timely information on the activities of state bodies and public associations, on political, economic, and international life, and on the state of the environment." Similarly, the law resolution of the Council of Minister no. 784 (May 29, 2001) executing the Law on Information defines the list of public entities that are requested to provide information on their activities on request of both public and nonpublic agents. This list includes the NBRB.

\subsubsection{Data sharing and coordination among data-producing agencies are adequate}

The NBRB meets regularly with the State Customs Committee (SCC) and the Minstat to discuss conceptual and methodological issues concerning data it obtains as part of the balance of payments compilation process.

Following a specific protocol, the SCC provides the Minstat with aggregates on export and import of goods, which the Minstat validates and compiles according to the trade statistics framework. The Minstat on a monthly basis provides the NBRB with data on foreign trade. Based on these data and on information provided by the SCC, the Balance of Payments 
Department (BOPD) compiles data on exports and imports of goods according to the BPM5. The reconciliation is possible because the SCC's customs and statistical declarations forms have been designed, and are constantly discussed for improvements with the NBRB. Similarly the forms sent on a quarterly basis by the Minstat to resident enterprises covering their external financial transactions are designed in coordination with the NBRB to comply with the balance of payments methodological framework.

The effective and timely flow of input data from the SCC, the Minstat, the MoF, and the Ministry of Communication to the NBRB regulated by bilateral protocols signed by the Governor and the relevant ministries.

Regular meetings are held with other data producing agencies to promote a proper understanding of data requirements, to avoid duplication of effort, and to take into account reporting burden. In 2000, an Inter-Agency Council on Balance of Payments Statistics was established to promote the understanding and development of balance of payments statistics in the Republic of Belarus. It was headed by the NBRB's first Deputy Chairman.

A new Interagency Council of Statistics, headed by the Deputy Prime Minister, was set up in 2003. This Council has overall responsibility on conceptual and methodological issues related to all macroeconomic statistics. It ensures that the data coordination between agencies involved in the production of balance of payments statistics is effective. Any problem indicating potential trade-offs or conflicts between objectives set at the level of each data producing agency is discussed and solutions are agreed upon. The head of the NBRB's Balance of Payments and Banking Statistics Main Department is a member of this Council. Among participating agencies are the NBRB, the Minstat, the Ministry of Economy, the MoF, the Ministry of Agriculture and Food, the Ministry of Justice, the Ministry of Industry and the National Academy of Science of Belarus.

\subsubsection{Individual reporters' data are to be kept confidential and used for statistical purposes only}

The form for the provision of data following the International Transactions Reporting System (ITRS) clearly informs respondents that data are confidential at the level of the single reporting agent, and that the information is collected for statistical purposes only. It also clarifies that the forms are only used for the compilation and dissemination of balance of payments aggregates.

The NBRB receives some input data directly from certain companies. For instance, it receives data from three energy enterprises involved in foreign trade. Data are sent by these companies following bilateral protocols signed by the Governor of the NBRB, which clearly stated that the "data are confidential and used for statistical purposes."

The nondisclosure of single data is also mentioned in the NBRB's Staff Code of Professional Ethic of Employees, as well as in the document on the Balance of Payments Department's Internal Procedures. 
Data on enterprises' financial account transactions are sent to the NBRB by the Minstat on an aggregated basis. The form used by the Minstat to collect these data clarifies the confidential nature of the survey. It also indicates that data are gathered for statistical purposes only.

\subsubsection{Statistical reporting is ensured through legal mandate and/or measures to encourage response}

Reporting under the Republic of Belarus's balance of payments data collection system is obligatory according to the law. Article 34 of the Banking Code grants the NBRB the right to request from banks and nonbanks credit and financial institutions on all matters related to their activity. Similarly, the Law of the Republic of Belarus on State Statistics provides the legal framework for the collection of statistics from public and private nonfinancial enterprises. This law is used by the Minstat and the NBRB to collect data directly from enterprises. Other data are collected on a voluntary basis. These include the survey on tourism and the survey on retail import of goods through domestic open markets, which is used to estimate shuttle trade.

\section{$0.2 \quad$ Resources}

\subsubsection{Staff, facilities, computing resources, and financing are commensurate with statistical programs}

The Balance of Payments Department consists of three divisions covering (a) the current account, (b) the financial account, and (c) methodological issues, for a total number of 16 staff members (including the department head). The number of staff is considered to be sufficient in normal times to perform the tasks of compiling and disseminating balance of payments statistics. However, recent developments in terms of SDDS requirements (for example, reserves template, external debt statistics, and the planned inclusion of financial derivatives in the balance of payments statistics) indicate the need for both ongoing training at international level and some additional resources.

The mission supports the NBRB strive for ongoing training. It also recommends that consideration be given to assess resource availability against current and near-future new tasks.

An upgrade to the computing resource took place in 2003, resulting in the provision of more up to date computers. The Information Technology Department (ITD) assists the Balance of Payments Department in terms of database design, testing, implementation, and management.

A recent law has brought the status of NBRB staff at the same level of other civil servants. This law resulted in a dramatic decrease in the managers' ability to reward employees based on their performance. Whereas the bonus system in place, according to the previous staff regulation, allowed bonuses for up to 100 percent of the basic salary; the current threshold is 
now about 35 percent. The NBRB is experiencing serious difficulty to retain qualified employees, in particular junior professionals. There are clear indications that the NBRB ranks within the domestic banking sector in terms of salary and benefits provided to its employees. This causes a certain concern among NBRB's managers.

\subsubsection{Measures to ensure efficient use of resources are implemented}

The Balance of Payments Department discusses each year the working program for the coming year. Each employee is encouraged to provide her/his opinion on ways to improve the human resource allocation and set priorities. This feedback is provided based on both informal meeting as well as during regular Division's meetings and annual performance review discussions.

\section{$0.3 \quad$ Relevance}

\subsubsection{The relevance and practical utility of existing statistics in meeting users' needs are monitored}

The NBRB is actively involved in seeking on an ongoing basis the views of the official users regarding the perceived relevance of balance of payments statistics. Regular formal and informal meetings are held with the MoF, the Minstat, the SCC, and the Ministry of Foreign Affairs, to discuss their needs in terms of external sector's statistics. Besides conducting these discussions on a bilateral basis, the Inter-Agency Council of Statistics provides a framework for involving all official users in joint meetings dealing with balance of payments statistics.

In view of the planned monetary union with Russia, Balance of Payments Department's staff meets on a quarterly basis with colleagues of the Central Bank of Russia to discuss issues on uses and users of the respective balance of payments and of the bilateral balance of payments, which has been compiled starting from 2000. These meetings take place in the frame of a dedicated Interbank Working Group on Balance of Payments Methodological Issues (WGBP). Similar discussions on evolving needs in terms of balance of payments, international investment position, and reserves asset issues are conducted during regular meetings of the Belarus-Russia Interbank Currency Board.

Because of its leading role in organizing various seminars and lectures in the Belarus State Economic University on balance of payments issues, the Balance of Payments Department maintains an open channel of communication with students and chairs of economics on their needs in terms of external sector statistics. These views are reported to the managers of the Balance of Payments Department as input for assessing overall relevance of the balance of payments data. 


\subsection{Other quality management}

\subsubsection{Processes are in place to focus on quality}

The Inter-Agency Council of Statistics provides a framework for discussing issues related to the quality of the balance of payments statistics.

As specified in the document defining internal procedures and organizational aspect, the Balance of Payments Department is responsible for monitoring, on an ongoing basis and at each phase of the statistical production, the quality of the data both at the level of the processes as well as at the level of the output aggregates. The Computer System and Technology Department carries out all preliminary consistency checks on statistical inputs.

The quality of the bilateral balance of payments between the Republic of Belarus and the Russian Federation is discussed regularly within the WGBP, including detailed analysis of the bilateral asymmetries and the creation of ad hoc task forces to implement shared methodologies based on international standards.

Under the current NBRB's organization, managers are directly responsible for the quality of the statistics compiled in the respective areas.

\subsubsection{Processes are in place to monitor the quality of the statistical program}

Data obtained from the ITRS by each reporting bank are checked for internal and logical consistency based on automated validation rules. They are also assessed for plausibility following time series analysis and comparison across datasets. If inconsistent data are entered in the ITRS form, the NBRB's database will identify the wrong entries and the ITRS form will be sent back to the commercial bank for correction and clarification. In the cases in which the commercial bank fails to provide correct data, the Governor of the NBRB may write a letter drawing attention on the quality of the data and requesting immediate followup.

Data obtained from parallel sources are checked for consistency. For instance, data collected on enterprises financial transactions both from the ITRS and from direct reporting through the Minstat are comprised and discussions are held to assess the quality of both data sources.

The level of errors and omission is regularly reviewed.

\subsubsection{Processes are in place to deal with quality considerations in planning the statistical program}

The Balance of Payments Department work program is discussed on a yearly basis by the departments and the three division chiefs. It describes the plans for the coming year in terms of statistical production, methodological issues, priorities, trade-offs, and available resources. The document takes into consideration the regular discussions within the Balance of 
Payments Department, the Inter-Agency Council of Statistics, and the WGBP on quality improvements identified during ongoing monitoring and in periodic reviews.

The Balance of Payments Department, directly or through the Director of the Main Department of Balance of Payments and BSD, explains and assesses the trade-offs in terms of overall quality of statistics deriving from new data requests (and data collection and compilation programs) from other agencies. These considerations are normally discussed at the level of the Interagency Council on Statistics and brought to the Governor's attention.

\section{Assurances of integrity}

\subsection{Professionalism}

\subsubsection{Statistics are produced on an impartial basis}

Article 3 of the Law of the Republic of Belarus on State Statistics (1997) states that the main objectives and principles guiding the collection and compilation of statistics by state agencies are (a) objectivity and relevance of statistics; (b) intertemporal stability and consistency across datasets; and (c) accessibility and transparency.

Staff are recruited based on academic background. Promotions are regulated on the basis of their performance.

NBRB's staff are provided with a variety of training opportunities. The NBRB has a dedicated training center supporting staff's professional development through several seminars, lectures, and workshops. Moreover, the NBRB encourages staff to participate in seminars organized by the IMF and other international organizations. However, Balance of Payments Department's managers believe that their staff should be given more opportunities to follow international seminars and workshops and would welcome more frequent attendance at IMF courses, even for some senior managers.

The NBRB's staff is encouraged to participate in the country's academic discussions on balance of payments development by writing papers, publishing articles, and lecturing at university classes. The staff's regulations actually indicate that staff is allowed to actively involve themselves in external academic activity. As a matter of fact, the Balance of Payments Department is recognized to be at the frontier in terms of technical and academic expertise in the field of economic development of the external sector and balance of payments conceptual issues.

\subsubsection{Choices of sources and statistical techniques as well as decisions about dissemination are informed solely by statistical considerations}

The decision to design the country's data collection system centered on the ITRS. This is due to the fact that the NBRB has a close relation with the system of domestic banks (which it 
supervises), and that the current exchange control system allows for domestic financial institutions to cover the vast majority of external transactions.

Balance of payments statistics are disseminated solely on the base of statistical considerations.

\subsubsection{The appropriate statistical entity is entitled to comment on erroneous interpretation and misuse of statistics}

The Balance of Payments Department plays a proactive role in ensuring the correct interpretation of balance of payments statistics. This is achieved in various ways. In the NBRB's regular bulletin, changes in the methodological framework or in data collection approaches are described to users. Moreover, the Balance of Payments Department organizes several seminars with official and nonofficial users to clarify the balance of payments conceptual framework. In the meeting dedicated to questions to the NBRB's staff, possible misinterpretation of the balance of payments statements are clarified. For instance, a change was introduced in 2003 on the approach to collect and compile data on travel. To ensure correct interpretation of the new results, the Balance of Payments Department organized several meetings with the Minstat, the Ministry of Foreign Affairs, the Ministry of Sport and Tourism, and the Agency for Tourism. Similarly, the Balance of Payments Department's managers wrote several articles in the specialized press commenting on balance of payments developments during last two to three years.

\subsection{Transparency}

\subsubsection{The terms and conditions under which statistics are collected, processed, and disseminated are available to the public}

All relevant regulations supporting the collection of balance of payments statistics are mentioned in the appropriate forms. For instance, the ITRS forms make references to the Banking Code, authorizing the NBRB to collect information from public and private agents on their cross border payments through domestic commercial banks.

\subsubsection{Internal governmental access to statistics prior to their release is publicly identified}

In line with the document on internal procedures, balance of payments statistics are checked and approved by NBRB's managers the day before they are placed on the NBRB's external web site, which occurs 90 days after the end of the reference quarter. In any case, there is no prior disclosure of data outside the NBRB.

\subsubsection{Products of statistical agencies/units are clearly identified as such}

All balance of payments statistics are disseminated with a clear indication about the NBRB's responsibility in collecting and compiling the data. Balance of payments statistics are disseminated on the NBRB's web site and in the following NBRB's publications: the 
Quarterly Bulletin on Balance of Payments and International Investment Position Statistics, the Bank Bulletin Magazine (monthly), the National Economic Gazette (issued twice a week), the Bulletin of Banking Statistics (monthly). All these publications are clearly identifiable as NBRB's products.

\subsubsection{Advanced notice is given of major changes in methodology, source data, and statistical techniques}

The Balance of Payments Department traditionally provides users with prior information on forthcoming changes in methodology, source data, and statistical techniques. This is normally done in the Balance of Payments and International Investment Position Statistics. When the changes impact the design of the survey forms, the Balance of Payments Department organizes seminars with users and respondents, describing the scope for the changes and educating on ways to fill the questionnaires.

\subsection{Ethical standards}

\subsubsection{Guidelines for staff behavior are in place and are well known to the staff}

The NBRB's Code of Professional Ethic of Employee (introduced in April 2003), which is included in the informative package provided to new staff and sent to all NBRB's staff whenever some updates occur, clearly identifies norms of conduct and the general ethical framework that should be followed in specific situations.

\section{Methodological soundness}

\subsection{Concepts and definitions}

\subsubsection{The overall structure in terms of concepts and definitions follows internationally accepted standards, guidelines, or good practices}

Belarusian balance of payments mostly follows the concepts and definition set out in BPM5. A recent development in the conceptual framework towards the full compliance with BPM5 include the definition of the foreign direct investment component in line with the 10 percent ownership rule.

Currently, the balance of payments compiled by the NBRB does not include the functional category of financial derivatives within the financial accounts. The NBRB is engaged in discussing the possibility to collecting and compiling data on financial derivatives in 2004. The Balance of Payments Department of the NBRB believes that financial derivatives do not yet play an important role in the domestic financial market. This view is based on regular assessments of the domestic financial market by the Main Department of International Transaction, which includes an analysis of the use of financial derivatives by domestic financial institutions. 


\section{$2.2 \quad$ Scope}

\subsubsection{The scope is broadly consistent with internationally accepted standards, guidelines,} or good practices

All resident-nonresident transactions are included in the balance of payments. A very comprehensive data collection system, centered around a closed ITRS complemented by direct reporting and a set of estimations based on sound methodology, is used. Unincorporated branches are included among resident enterprises operating in the Republic of Belarus. All registered enterprises are requested to report, on a quarterly basis, comprehensive statements covering foreign direct investment, portfolio investment, and other investment stock and flow data.

The NBRB, in cooperation with the Minstat, has designed a new methodology to improve the coverage of shuttle trade. This methodology relies on two surveys. The first survey addresses the coverage of shuttle trade using the commodity flow model. This survey has been conducted by the Minstat since 1996. The second survey provides additional information on shuttle trade on the basis of the structure of household expenditures related to purchases of imported goods on domestic open markets, complemented by direct observation on these open markets. The survey enables the estimation of a sizeable proportion of otherwise unrecorded shuttle trade.

In 2001 the approach to estimate import and export with the Russian Federation (accounting for some 50 to 60 percent of total merchandise trade) has changed. Prior to this change, data on trade with the Russian Federation were based on a monthly survey of all enterprises engaged in foreign trade. This approach failed to cover physical persons engaged in entrepreneurial activities. Since April 2001, the new survey collects data on trade with the Russian Federation based on statistical declaration forms that must be completed by all entities including individual entrepreneurs.

\subsection{Classification/sectorization}

\subsubsection{Classification/sectorization systems used are broadly consistent with internationally accepted standards, guidelines, or good practices}

The classification and sectorization followed by the NBRB to compile balance of payments statistics are broadly consistent with BPM5's conceptual framework. The sector classification is ensured by the mandatory inclusion of the transactor code in the ITRS form.

In the balance of payments framework, government guaranteed external debt transactions are attributed to the institutional sector of the borrower and public enterprise claims and liabilities are attributed to other sectors. Borrowing and lending_-including debt securities and supplier's credits - between direct investors and direct investment enterprises are classified under the foreign direct investment, except when those transactions are between affiliated financial intermediaries. Loan transactions of the banking sector are classified 
separately from currency and deposits transactions of this sector. Under other investments, the breakdown into long- and short-term maturity component is made according to the original maturity of the financial instrument.

\section{$2.4 \quad$ Basis for recording}

\subsubsection{Market prices are used to value flows and stocks}

The Belarusian balance of payments statistics are compiled in U.S. dollars. In line with the BPM5 recommendations, data on transactions in foreign currency collected through the ITRS are converted using the midpoint exchange between buying and selling rates prevailing in the market on the transaction date.

In 2003, the NBRB agreed to adopt the BMP5's recommendation to value monetary gold at market prices.

Appropriate substitute measures and reporting instructions are used when no actual market prices are available. This applies to barter trade data, which are collected through customs or statistical declarations with a clear indication in the reporting form that exporters/importers should make an attempt to value barter trade at a notional market value. The same applies for transactions between affiliated enterprises.

Portfolio investment flows of the banking sector are derived from stock data, that is, the changes in stocks between two reference periods. Since stock data are reported in the original currency, efforts are made to exclude valuation and other changes in the flow data. However, stock at the end of the period are converted at the exchange rates of the previous period. The valuation changes are independently calculated and the flow changes are derived as a residual. The mission recommends that flow changes be calculated independently and the valuation and other changes derived as residual. Because stocks are in the original currencies, changes in stocks are equal to the flow changes. These flow changes in the original currencies need to be converted at the average monthly exchange rates or the average exchange rate over the shortest period possible.

\subsubsection{Recording is done on an accrual basis}

The change in ownership criteria is recognized as the basis for compiling the Belarusian balance of payments. The customs and statistical declarations allow for a full implementation of the change of ownership criteria in the field of trade in goods. Borrowing under external public debt is valued on an accrual basis, based on the very detailed information maintained by the MoF on characteristics of each loan either contracted or guaranteed by the public sector. Income accrued on the banking sector's financial stocks (other than securities) and on the public and publicly guaranteed external loans is calculated by applying income yield based on average market yield for different classes of securities, and it takes into account the specific structure of domestic entities' portfolio investment assets. Foreign direct investment dividends are recorded when they are paid. 
Because of the growing importance of the nonguaranteed external debt and loans, the mission recommends that consideration be given to establish a methodology for compiling estimates of the related interest payments on an accrual basis. The mission also recommends that income on banking sector holdings in securities be calculated on an accrual basis.

\subsubsection{Grossing/netting procedures are broadly consistent with internationally accepted standards, guidelines, or good practices}

In line with the recommendations of BPM5, current and capital account transactions are recorded on a gross basis, while financial account transactions are recorded separately for the individual asset and liability components.

\section{Accuracy and reliability}

\subsection{Source data}

\subsubsection{Source data are obtained from comprehensive data collection programs that take into account country-specific conditions}

Balance of payments statistics are compiled based on a comprehensive data collection system. This is centered around the ITRS, a set of surveys based on sound methodologies, customs and statistical declarations obtained from the SCC, reporting from the MoF on external transaction of the general government, reports from the NBRB, and report from all domestic enterprises engaged in cross-border financial transactions. Given the legal and institutional framework in place in the Republic of Belarus, the balance of payments data collection system provides for sound coverage of domestic entities' external transactions.

The following are a review of the primary data sources according to balance of payments components:

- Goods: there are two primary data sources used to collect monthly information to compile merchandise trade. The first source cover trade data with all partner countries apart from the Russian Federation. It is based on customs declaration of goods crossing the borders collected by the SCC. The second source covers trade data with the Russian Federation. Because progress in establishing a monetary and economic union between the Republic of Belarus and the Russian Federation has resulted in the elimination of controls at the common border, data on trade with the Russian Federation are collected from a statistical declaration. The statistical declaration forms must be filled by all enterprises involved in trade with the Russian Federation, including individual entrepreneurs. As trade conducted by individuals play a significant role, these forms represent a substantial improvement in coverage, compared to the previous system to collect data based on regular reports from registered enterprises only. 
Because of some concern about the quality of customs and statistical declarations in categories of goods related to single domestic companies, the Minstat obtains certain data directly from these companies. For instance, the extraction and exports of potassium are conducted by a single enterprise, which provides relevant information directly to the Minstat. Similarly, data on exports and imports (including barter trade) are provided directly to the NBRB by the three energy enterprises that are involved in foreign trade.

The Minstat's survey on the commodity structure of households' expenditure in import goods sold in domestic open markets is used by the NBRB, together with direct observations on the commodity structure of the retail trade actually occurring in open markets, to integrate the Minstat's estimation on shuttle trade based on the commodity flow model.

- $\quad$ Services: as a general rule, data on import and export in services are collected through the ITRS, with the following exceptions.

Data on import and export in transport, communication, construction, and oil refinery services are compiled by enterprises operating in these sectors based on the Report on Export and Import of Service (Form 3) sent by the Minstat. The Minstat is in charge of maintaining and updating the business register for statistical purposes, which allows the identification of relevant enterprises in different sectors.

Passenger and freight transport data are compiled monthly based on Form 3 completed by Belarusian railways and the airlines. The data are based on estimates on the share of nonresident passengers, and the share of nonresident customers of freight services related to cargos in transit across the Republic of Belarus. These data are provided to the NBRB on a quarterly basis.

Credit and debit data on travel are estimated based on yearly surveys on the breakdown by country of origin (credit) and destination (debit) of total travelers, calculated for each category of travel. This information is used in the following year by multiplying it by a coefficient of increase/decrease of tourism flows. Yearly data on travel inflows and outflows are allocated to quarters of the subsequent year based on current quarterly seasonal coefficients estimated by the Minstat. The data are compared with information on net sales of foreign exchanges collected on a monthly basis by the NBRB, and with data collected from the ITRS for the same item.

Monthly communication services data for credits and debits based on Form 3 are sent to the NBRB by the Ministry of Communication, the state monopoly in the communication field.

Data on export of construction services are supplied on a monthly basis by one company using Form 3, which is used to check the ITRS information, and is also used as the main source since barter trade does not play the same role of the previous 
years. This company provides construction services in the Russian Federation as barter payment for gas supply.

Form 3 data on services related to processing of crude oil imported from the Russian Federation and exported to third countries as finished product are provided on a monthly basis.

Receipts of government services for the operation of foreign embassies and other missions located in the Republic of Belarus are estimated on the basis of the Ministry of Foreign Affairs' data on total number of staff multiplied by NBRB's estimates on per capita expenditure. Annual data on the expenditure of Belarusian embassies and other missions in foreign countries are provided to the NBRS.

The service data described above are compiled using other sources than the ITRS as primary sources. However, ITRS data are always used as a checking tool.

Insurance services are calculated based on the ITRS data on credits and debits separately for premiums and claims. The export of services is calculated by multiplying the premium received by a coefficient based on an average difference between insurance's claims to nonresidents less premium paid from nonresident.

\section{Income}

Compensation of employees: inflows and outflows are calculated based on data on individuals crossing the border for temporary jobs. These data are calculated by the SCC (outflow) and by the Russian Federation and Ukraine (inflows). The NBRB calculates the average remittance based on estimations on the average stay and salary, and a coefficient of transfer.

Direct investment income: the estimation procedure for direct investment income inflows and outflows is based on information derived on surveys of foreign direct investment conducted through a new survey form (the Minstat's Form 2), introduced in 2000 following an IMF's recommendation. The NBRB took an active role in developing Form 2. Enterprises are required to report data on reinvestment of earning on the basis of the recommendation of the $B P M 5$, that is, including depreciation, but excluding the sale of assets, write-offs, and realized capital gains and losses less dividends and distributed profits. Form 2, however, does not specify that the distributed income needs to be prorated in accordance with the share of direct investor.

The mission recommends that the Form 2 should clearly specify that the distributed income have to be provided in accordance with the direct investor's share in the direct investment company.

Portfolio investment income: data are derived from the ITRS. Separate codes are provided to distinguish between income on equity and income on debt securities. The ITRS does not 
provide a distinction between income on bonds and notes and income on money market instruments. The mission recommends that separate codes be introduced in the ITRS to identify income on bonds and notes, and income on money market instruments.

Other investment income: The data source varies depending on the sector. (ITRS data are used as a checking tool only). For monetary authorities, the data are provided by the NBRB. Data on the general government are calculated on the basis of the MoF's comprehensive database on external debt. For the banking sector, the Balance of Payments Department uses a model based on the structure of foreign assets and liabilities of commercial banks, based on monthly balance sheets. For other sectors, the MoF provides debit data on interest payments for loans guaranteed by the government. These data are supplemented by the NBRB's data on interest payments on unguaranteed debt and loans on accounts held abroad, reported on a monthly basis on a cash basis.

\section{Current transfer}

General government: data on current transfer in kinds related to humanitarian aid and technical assistance in kind are calculated based on the customs and statistical declarations. Current transfers using the banking system are obtained from the ITRS.

Workers' remittances: data are derived from the ITRS. As most of the workers' remittances are known to come from nonCIS countries, the Balance of Payments Department makes the assumption that Belarusian residents in those countries are likely to use remittances rather than cash.

Other current transfers: debit and credit data on current transfers using the banking system are obtained from the ITRS, which provides separate codes for other current transfers, which including items such as financial gifts, fees and contributions to scientific, charitable and religious organizations, and payments of taxes, and penalties.

General government: separate codes are provided in the ITRS for capital transfers of the general government sector.

Other sector: capital transfer and migrants' transfers: separate codes are provided in the ITRS for capital transfers to or from the banking sector and other sectors.

The data on migrants' transfers are derived from a model used by the Balance of Payments Department that uses data on the number of migrants who have entered or left the Republic of Belarus, multiplied by the average value of the migrants' effects. Data provided by the SCC on available effects to be taken into and out of the country were used to establish a benchmark for the value of migrant's effects and the benchmark is adjusted to take into account foreign exchange rates and prices.

Acquisition/disposal of nonproduced nonfinancial assets: data are derived from the ITRS. 


\section{Financial account}

Direct investment: quarterly data on direct investment flows and stocks are collected by the Minstat through Form 2. It covers stocks and flows of direct investment, portfolio investments, and other investments. The Minstat set up a very comprehensive business register containing most up-to-date information on active enterprises. This register is updated by including every new company that is registered based on the registration act maintained by the Ministry of Justice. The Minstat's business register covers some 12,000 active companies. It is used for statistical purpose only.

Towards the end of each year, the Minstat sends Form 2 to all active companies for the subsequent four quarters. Companies that are not involved in foreign direct investment (as well as other kinds of external financial transactions) inform the Minstat about this situation. As a result they do not have to fill Form 2.

The Central Bank of the Russian Federation provides the NBRB with information on direct investment stocks and flows from one company active in the field of gas extraction and distribution.

Portfolio investments: the main sources for portfolio investment are the reports from banks, Form 2, and the records of the NBRB for the portfolio investment transactions of the NBRB. The ITRS is used as an alternative source used for checking purposes.

Other investment: data on trade credits and arrear assets and liabilities (on exports/imports of goods and services) are provided by the Minstat based on Report on Claims and Liabilities of Enterprises (Form 6-f). The three energy enterprises report directly to the NBRB on their other investment transactions. Assets and liabilities data on foreign loans of general government, as well as for loans guaranteed by the government (together covering approximately 20 percent of total outstanding foreign debt liabilities of the nonbanking sector) are provided by the MoF. Commercial banks report to the NBRB, on a monthly basis, their balance sheet. Data on unguaranteed loans are compiled based on the NBRB's survey form Foreign Exchange Accounts Held Abroad by Residents for "Unguaranteed" Debts Transactions.

Currency and deposits: the assets and liabilities data are obtained from the monthly balance sheet reported by commercial banks to the NBRB.

Other assets and other liabilities: data recorded under other assets (liabilities) represent transactions regarding the arrears owed to (by) the Republic of Belarus. Data are collected by the Minstat in Form 6-f for all companies except the three energy enterprises.

Reserves assets: transactions in reserves assets are calculated on the basis of records of the NBRB. In line with the Belarusian institutional setting, the functional category of monetary authorities includes the central bank and certain operations of the general government. For instance, the proceeds of the sale of a share of government's participation in a joint venture 
(Sibnet), which were settled in foreign exchange and are owned by the government in forms of foreign exchange deposits placed with the NBRB, are included as part of the reserve assets.

\subsubsection{Source data reasonably approximate the definitions, scope, classifications, valuation,} and time of recording required

Source data drawn from surveys and ITRS are consistent with the definitions, scope and classifications, and the time of recording of the balance of payments statistics employed by the NBRB.

Information on external debt obtained from the MoF is broadly in line with the recommendations of the $B P M 5$.

\subsubsection{Source data are timely}

Data collection and processing timetables are adequate to meet timeliness and periodicity for disseminating the balance of payments statistics.

In all reporting forms (ITRS, Forms 2 and 3), respondents are made aware of the deadlines set for reporting.

The NBRB employs rigorous follow-up procedures to ensure the timely receipt of respondents' data. Delays in providing ITRS returns are monitored closely. When they occur, the Balance of Payments Department contacts immediately the commercial banks to investigate the reason for the delay. In general, the institutional framework in the Republic of Belarus promotes strict adherence to the reporting timetable.

\subsection{Assessment of source data}

3.2.1 Source data - including censuses, sample surveys and administrative records-are routinely assessed, for example, for coverage, sample error, response error, and nonsampling error; the results of the assessments are monitored and made available to guide statistical processes

Each ITRS report is checked to ensure correct reporting. In case single sub-items and totals are not consistent, the NBRB data reception system identifies the problem and do not allow for the data to be entered in the ITRS database system. Each report is also checked, at the level of each reporting commercial banks, for time series plausibility. The recurrent use of residual categories is monitored, and commercial banks are contacted to provide further explanations.

Form 2 data are checked for consistency and plausibility at each of the three administrative levels of local administration according to which the Minstat is organized. 


\subsection{Statistical techniques}

\subsubsection{Data compilation employs sound statistical techniques to deal with data sources}

Appropriate measures are undertaken when the value of uncoded ITRS transactions below the threshold becomes too large.

3.3.2 Other statistical procedures (for example, data adjustments and transformations, and statistical analysis) employ sound statistical techniques

Specific procedures are developed to adjust data from various sources to improve coverage, classification, and valuation, and conform to guidelines set out in BPM5.

- The c.i.f./f.o.b. factor for valuing imports is estimated each five years on the basis of ITRS data and information obtained from the customs and statistical declaration on the terms of delivery (c.i.f. or f.o.b) of the goods. The c.i.f./f.o.b. factor estimates are done for similar category of goods and country of origin and destination.

- $\quad$ Travel data are estimated as follows. Data are collected by NBRB from each border on the structure of travelers crossing the border. The information includes country of origin or destination, purpose of the travel, and average length of stay. This matrix of information is compiled by a joint effort of the Ministry of Sport and Tourism and the Ministry of Foreign Affairs. The NBRB is in charge of the methodological aspects and the survey design. It also coordinates the collection of data among other ministries. The NBRB collects information on the average expenditure of travelers for each category.

- $\quad$ Estimates of shuttle trade are made based on information from periodic surveys conducted at major border points on goods carried by organized and nonorganized traders, and data are extrapolated from the monthly volume of shuttle traders identified by customs and immigration authorities.

- $\quad$ Because shuttle trade is a relevant feature of the Belarusian economy, the NBRB and the Minstat have designed a sound methodology to estimate this item. This methodology is based on two components (a) the commodity flow model, and (b) the result of the survey on household expenditure originating on purchases of import goods sold in open markets. The commodity flow model used by the Minstat compares, for selected categories of import goods, data on imports, local production, changes in stocks, and consumption within the Republic of Belarus. If data show that the sum of imports and production exceed the sum of consumption, exports, and changes in stocks, the difference is recorded under recorded export. If the sum is lower, it is adjusted and recorded under recorded import by the Minstat.

- $\quad$ On the import side, the estimations are based on the monthly survey on household expenditure, which provides information on total expenditure related to purchases on 
domestic and foreign open markets. These data are multiplied by the estimates on the share of purchase that occurs in domestic open markets and refers to imported goods only. Further, the share of legally declared imports (already covered in customs data) is excluded. Finally, a coefficient of profitability is applied. (This assesses the average discount applied on open market compared to the formal retail sales.) On the export side, surveys at the customs on the amount of shuttle trade in goods not included in the commodity flow model are done by the NBRB together with the SCC and the Minstat.

\subsection{Assessment and validation of intermediate data and statistical outputs}

\subsubsection{Intermediate results are validated against other information where applicable}

Intermediate results are checked across a wide range of data sources. Form 2 data on domestic enterprises foreign direct investment transactions are checked when reliable information on single transactions is reported in the financial press, in particular in case of high-value direct investment transactions.

\subsubsection{Statistical discrepancies in intermediate data are assessed and investigated}

The reported financial flow data are reconciled with changes in the corresponding stock data collected for external debt and for other elements of the international investment position.

\subsubsection{Statistical discrepancies and other potential indicators of problems in statistical outputs are investigated}

The Balance of Payments Department monitors on ongoing basis the level, sign, and developments of the errors and omissions. This constant focus on assessing the reasons behind the level of errors and omissions has been one of the reasons for introducing the survey on shuttle trade.

The NBRB is involved in regular exercises for assessing and reconciling the bilateral balance of payments data with the Russian Federation. This work is done each quarterly during bilateral meetings.

\subsection{Revision studies}

\subsubsection{Studies and analyses of revisions are carried out routinely and used internally to} inform statistical processes (see also 4.3.3)

Revisions, in particular in the trade statistics, are constantly monitored and discussed in bilateral meetings between the NBRB and the Minstat. 


\section{Serviceability}

\subsection{Periodicity and timeliness}

\subsubsection{Periodicity follows dissemination standards}

Balance of payments statistics are disseminated quarterly and, accordingly, meet the periodicity requirements of the SDDS.

\subsubsection{Timeliness follows dissemination standards}

Balance of payments statistics are disseminated one quarter after the reference period and, accordingly, meet the timeliness requirements of the SDDS.

\subsection{Consistency}

\subsubsection{Statistics are consistent within the dataset}

Annual balance of payments statistics are compiled from quarterly data, ensuring that consistency is achieved within datasets of different periodicity. The concepts, definitions, and classifications are, therefore, identical across datasets of different periodicity.

\subsubsection{Statistics are consistent or reconcilable over a reasonable period of time}

Consistent time series are available since 1996. When changes in source data, methodology, or techniques are introduced, historical series are reconstructed as far back as reasonably possible.

\subsubsection{Statistics are consistent or reconcilable with those obtained through other data sources and/or statistical frameworks}

The Republic of Belarus's balance of payments data are broadly consistent or reconcilable with merchandise trade data, national accounts, monetary, external debt and international investment position statistics, as follows:

- the NBRB's data on goods are derived from the SCC's merchandise trade data, with coverage, classification, and valuation adjustments, as well as those on repair of goods and volume of imports/exports of goods purchased in ports. These are made on the basis of information derived from other sources including direct reporting from energy companies. Estimates for shuttle trade are produced;

- balance of payments data are a direct input to the external sector of the national accounts; 
- balance of payments data on cross border transactions of banks are reconcilable with monetary statistics;

\subsection{Revision policy and practice}

\subsubsection{Revisions follow a regular and transparent schedule}

The revision policy for balance of payments statistics is described in the NBRB's Quarterly Balance of Payments Bulletin as follows:

- $\quad$ regular revisions are included in the balance of payments each quarter and can affect data up to four quarters. These are caused mainly by routine revisions to source data, as reported by respondents; and

revisions due to methodological changes, and following the yearly revisions on trade data by the Minstat, are published in the first quarter of each year.

\subsubsection{Preliminary and/or revised data are clearly identified}

Although the revision calendar is clearly disseminated, and includes information on the time frame for revisions according to different reasons, the data presented in the tables do not allow for visual distinction between preliminary, revised, and final data.

\subsubsection{Studies and analyses of revisions are made public (see also 3.5.1)}

Revisions are measured, assessed, and explained in the regular balance of payments publications. Ad hoc tables showing the difference between preliminary and revised data are disseminated for the trade in goods item.

\section{Accessibility}

\subsection{Data accessibility}

5.1.1 Statistics are presented in a way that facilitates proper interpretation and meaningful comparisons (layout and clarity of text, tables, and charts)

Yearly and quarterly balance of payments series since 1996 are disseminated in accordance to BPM5's standard components in the NBRB's Quarterly Balance of Payments Bulletin. This publication provides a wide range of statistics on the external sector, intended to meet the needs of various users. It analyzes and comments on trends in balance of payments, identifies the driving items explaining the observed patterns, and presents statistics in forms of very user-friendly tables, charts, and graphs.

Besides showing balance of payments data according to the standard component and the analytical presentation, the publication also provides a number of additional breakdowns of 
balance of payments items. This allows for focusing on specific balance of payments features of the Belarusian economy, such as import and export of energy items.

Balance of payments statistics are also available on the NBRB's web site, with a presentation based on spreadsheets supporting more time-series analysis. Online yearly and quarterly data are available from 1993 and 2001Q1 onwards, respectively.

Balance of payments' broad indicators and more detailed merchandise trade in goods are published in the monthly Bulletin of Banking Statistics.

Seasonally adjusted balance of payments data are not compiled.

\subsubsection{Dissemination media and format are adequate}

Statistics are disseminated in formats that broadly suit users' needs. Detailed analytical information (ad hoc charter, tables, and graphs) is available on the NBRB's Quarterly Balance of Payments Bulletin as paper publication only. Although the ad hoc charter, tables, graphs are not available on the NBRB's web site as electronic file, balance of payments statistics are disseminated as spreadsheet database. As a result, users can access the online database and select data for specific years and quarters.

There are no specific media release related to the dissemination of balance of payments updates and revisions.

\subsubsection{Statistics are released on a preannounced schedule}

An advance release calendar is provided in both the NBRB's Quarterly Balance of Payments Bulletin and Bulletin of Banking Statistics and on the external NBRB web site, which provides advance information on the balance of payments statistics release dates for the next four quarters.

Balance of payments statistics are released according to the pre-determined and announced schedule.

\subsubsection{Statistics are made available to all users at the same time}

Balance of payments statistics are made available to all users simultaneously on the 91st day after the reference quarters on the NBRB's web site. There is no advance briefing to the press.

\subsubsection{Statistics not routinely disseminated are made available upon request}

Ad hoc balance of payments statistics and reports are routinely provided to member of other ministries in preparation of balance of payments seminars and workshops, or as background 
materials during international negotiations (for instance, in the frame of negotiation with the World Trade Organization).

Ad hoc data requests to the Balance of Payments Department are also satisfied on an ongoing basis to accommodate specific needs of members of Belarus State Economic University (as well as other ministries and agencies) and to assist graduate students in the preparation of specific studies.

\subsection{Metadata accessibility}

5.2.1 Documentation on concepts, scope, classifications, basis of recording, data sources, and statistical techniques is available, and differences from internationally accepted standards, guidelines, or good practices are annotated

A summary on concepts, scope, classifications, and basis of recording underlying the balance of payments statistics is provided in the explanatory notes section attached to the Quarterly Balance of Payments Bulletin, and on the metadata posted on the NBRB's web site. Articles are also occasionally published in the same publication on the methodology followed in compiling and estimating specific balance of payments items. However, as these articles target nonspecialized users, the level of detail is not sufficient to assess how exactly the methodology may impact the data, what are the assumptions upon which the estimations are calculated, and what is the process in place to assess and review those assumptions on an ongoing basis. Moreover, as users would need to consult different issues of the Quarterly Balance of Payments Bulletin in order to have a complete picture about the balance of payments methodology, the Balance of Payments Department should consolidate the existing wealth of information in one single document and regularly update it. The mission recommends that this forthcoming methodological compendium be posted on the web site. In all cases, there is no mention about the departure from the international standards as far as the new balance of payments functional category of financial derivatives is concerned.

\subsubsection{Levels of detail are adapted to the needs of the intended audience}

Balance of payments statistics are disseminated in the NBRB's Quarterly Balance of Payments Bulletin and Bulletin of Banking Statistics publications, and on the NBRB's web site according to different level of details, to meet the needs of both specialized and nonspecialized users.

\subsection{Assistance to users}

\subsubsection{Contact points for each subject field are publicized}

The NBRB's Quarterly Balance of Payments Bulletin and Bulletin of Banking Statistics publications, as well as the NBRB's external web site, provide a clear reference of the department in charge of compiling and disseminating balance of payments statistics. They 
also specify the name, telephone number, and the e-mail address of the person to be contacted in the case users need assistance.

5.3.2 Catalogs of publications, documents, and other services, including information on any changes, are widely available.

The NBRB publishes, on a yearly basis, a comprehensive and up-to-date catalog of all NBRB's statistical publication in the December issue of the Bank Bulletin Magazine. In addition, the Magazine is posted on a regular basis on the NBRB's web site. 
Table 6. Republic of Belarus: Data Quality Assessment Framework (July 2003): Summary of Results for Balance of Payments Statistics

(Compiling Agency: Minstat)

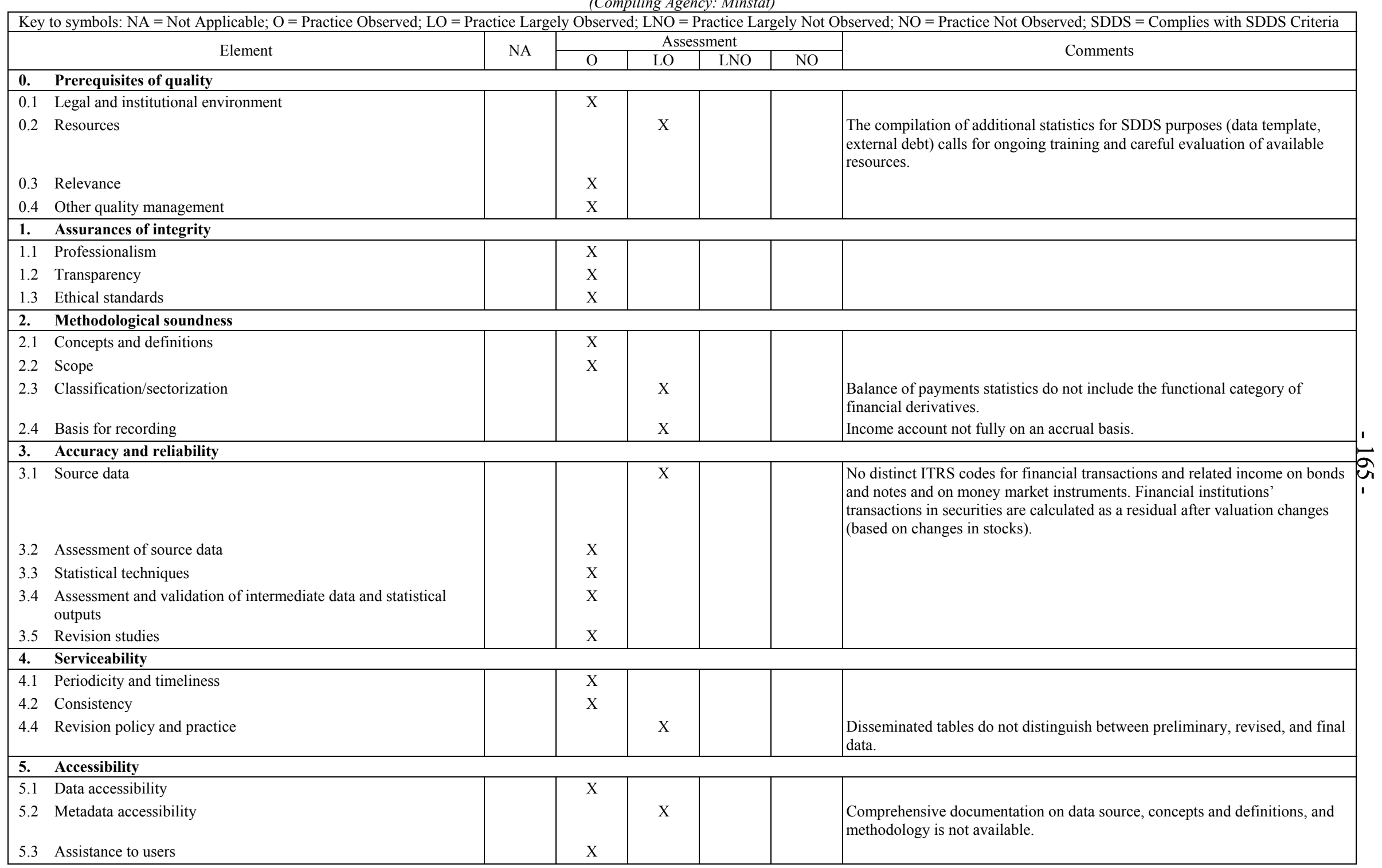

CInternational Monetary Fund. Not for Redistribution 


\section{Summary of the Special Data Dissemination Standard (SDDS)}

The SDDS prescribes the following practices under each of the identified dimensions:

Data dimension (coverage, periodicity, and timeliness)

- The dissemination of 18 data categories, including component detail, covering the four main sectors (real, fiscal, financial, and external) of the economy, with prescribed periodicity and timeliness.

\section{Access dimension}

- The dissemination of advance release calendars providing at least one-quarter advance notice of approximate release dates, and at least a one-week advance notice of the precise release dates; and

- $\quad$ The simultaneous release of data to all users.

\section{Integrity dimension}

- The dissemination of the terms and conditions under which official statistics are produced and disseminated;

- The identification of internal government access to data before release;

- The identification of ministerial commentary on the occasion of statistical release; and

- The provision of information about revision policy and advance notice of major changes in methodology.

\section{Quality dimension}

- The dissemination of documentation on statistical methodology and sources used in preparing statistics; and

- Dissemination of component detail and/or additional data series that make possible cross-checks and checks of reasonableness.

SDDS subscribers are required to:

- $\quad$ Post descriptions of their data dissemination practices (metadata) on the IMF's Dissemination Standards Bulletin Board (DSBB). Summary methodologies, which describe data compilation practices in some detail are also disseminated on the DSBB. 
- $\quad$ Maintain an Internet web site, referred to as the National Summary Data Page (NSDP), which contains the actual data described in the metadata and to which the DSBB is electronically linked.

The IMF staff is monitoring observance of the Standard through NSDPs maintained on the Internet. Monitoring is limited to the coverage, periodicity, and timeliness of the data and to the dissemination of advance release calendars.

Source: $\underline{\text { http: }: / d s b b . i m f . o r g}$ 


\section{Data Quality Assessment Framework-Generic Framework (July 2003 Framework)}

\begin{tabular}{|c|c|c|}
\hline Quality Dimensions & Elements & Indicators \\
\hline \multirow[t]{4}{*}{$\begin{array}{l}\text { 0. Prerequisites of } \\
\text { quality }\end{array}$} & $\begin{array}{l}\text { 0.1 Legal and institutional } \\
\text { environment-The environment } \\
\text { is supportive of statistics }\end{array}$ & $\begin{array}{l}\text { 0.1.1 The responsibility for collecting, processing, } \\
\text { and disseminating the statistics is clearly specified. } \\
0.1 .2 \text { Data sharing and coordination among data- } \\
\text { producing agencies are adequate. } \\
0.1 .3 \text { Individual reporters' data are to be kept } \\
\text { confidential and used for statistical purposes only. } \\
0.1 .4 \text { Statistical reporting is ensured through legal } \\
\text { mandate and/or measures to encourage response. }\end{array}$ \\
\hline & $\begin{array}{l}\mathbf{0 . 2} \text { Resources-Resources are } \\
\text { commensurate with needs of } \\
\text { statistical programs. }\end{array}$ & $\begin{array}{l}0.2 .1 \text { Staff, facilities, computing resources, and } \\
\text { financing are commensurate with statistical } \\
\text { programs. } \\
0.2 .2 \text { Measures to ensure efficient use of resources } \\
\text { are implemented. }\end{array}$ \\
\hline & $\begin{array}{l}\mathbf{0 . 3} \text { Relevance-Statistics cover } \\
\text { relevant information on the } \\
\text { subject field. }\end{array}$ & $\begin{array}{l}0.3 .1 \text { The relevance and practical utility of existing } \\
\text { statistics in meeting users' needs are monitored. }\end{array}$ \\
\hline & $\begin{array}{l}\mathbf{0 . 4} \text { Other quality } \\
\text { management-Quality is a } \\
\text { cornerstone of statistical work. }\end{array}$ & $\begin{array}{l}\text { 0.4.1 Processes are in place to focus on quality. } \\
\text { 0.4.2 Processes are in place to monitor the quality of } \\
\text { the statistical program. } \\
\text { 0.4.3 Processes are in place to deal with quality } \\
\text { considerations in planning the statistical program. }\end{array}$ \\
\hline \multirow{3}{*}{$\begin{array}{l}\text { 1. Assurances of } \\
\text { integrity } \\
\text { The principle of } \\
\text { objectivity in the } \\
\text { collection, } \\
\text { processing, and } \\
\text { dissemination of } \\
\text { statistics is firmly } \\
\text { adhered to. }\end{array}$} & $\begin{array}{l}\text { 1.1 Professionalism-Statistical } \\
\text { policies and practices are } \\
\text { guided by professional } \\
\text { principles. }\end{array}$ & $\begin{array}{l}\text { 1.1.1 Statistics are produced on an impartial basis. } \\
\text { 1.1.2 Choices of sources and statistical techniques } \\
\text { as well as decisions about dissemination are } \\
\text { informed solely by statistical considerations. } \\
\text { 1.1.3 The appropriate statistical entity is entitled to } \\
\text { comment on erroneous interpretation and misuse of } \\
\text { statistics. }\end{array}$ \\
\hline & $\begin{array}{l}\text { 1.2 Transparency-Statistical } \\
\text { policies and practices are } \\
\text { transparent. }\end{array}$ & $\begin{array}{l}\text { 1.2.1 The terms and conditions under which } \\
\text { statistics are collected, processed, and disseminated } \\
\text { are available to the public. } \\
\text { 1.2.2 Internal governmental access to statistics prior } \\
\text { to their release is publicly identified. } \\
\text { 1.2.3 Products of statistical agencies/units are } \\
\text { clearly identified as such. } \\
\text { 1.2.4 Advanced notice is given of major changes in } \\
\text { methodology, source data, and statistical techniques. }\end{array}$ \\
\hline & $\begin{array}{l}1.3 \text { Ethical standards-Policies } \\
\text { and practices are guided by } \\
\text { ethical standards. }\end{array}$ & $\begin{array}{l}\text { 1.3.1 Guidelines for staff behavior are in place and } \\
\text { are well known to the staff. }\end{array}$ \\
\hline
\end{tabular}




\begin{tabular}{|c|c|c|}
\hline Quality Dimensions & Elements & Indicators \\
\hline $\begin{array}{l}\text { 2. Methodological } \\
\text { soundness } \\
\text { The methodological } \\
\text { basis for the } \\
\text { statistics follows } \\
\text { internationally } \\
\text { accepted standards, } \\
\text { guidelines, or good } \\
\text { practices. }\end{array}$ & $\begin{array}{l}\text { 2.1 Concepts and definitions-- } \\
\text { Concepts and definitions used } \\
\text { are in accord with } \\
\text { internationally accepted } \\
\text { statistical frameworks. } \\
\mathbf{2 . 2} \text { Scope-The scope is in } \\
\text { accord with internationally } \\
\text { accepted standards, guidelines, } \\
\text { or good practices. } \\
\mathbf{2 . 3} \text { Classification/ } \\
\text { sectorization-Classification } \\
\text { and sectorization systems are in } \\
\text { accord with internationally } \\
\text { accepted standards, guidelines, } \\
\text { or good practices. } \\
\mathbf{2 . 4} \text { Basis for recording-Flows } \\
\text { and stocks are valued and } \\
\text { recorded according to } \\
\text { internationally accepted } \\
\text { standards, guidelines, or good } \\
\text { practices }\end{array}$ & $\begin{array}{l}\text { 2.2.1 The scope is broadly consistent with } \\
\text { internationally accepted standards, guidelines, or } \\
\text { good practices. } \\
\text { 2.3.1 Classification/sectorization systems used are } \\
\text { broadly consistent with internationally accepted } \\
\text { standards, guidelines, or good practices. }\end{array}$ \\
\hline $\begin{array}{l}\text { 3. Accuracy and } \\
\text { reliability } \\
\text { Source data and } \\
\text { statistical techniques } \\
\text { are sound and } \\
\text { statistical outputs } \\
\text { sufficiently portray } \\
\text { reality }\end{array}$ & $\begin{array}{l}\text { 3.3 Statistical techniques-- } \\
\text { Statistical techniques employed } \\
\text { conform to sound statistical } \\
\text { procedures } \\
\text { 3.4 Assessment and validation } \\
\text { of intermediate data and } \\
\text { statistical outputs- } \\
\text { Intermediate results and } \\
\text { statistical outputs are regularly } \\
\text { assessed and validated. } \\
\text { 3.5 Revision studies- } \\
\text { Revisions, as a gauge of } \\
\text { reliability, are tracked and } \\
\text { mined for the information they } \\
\text { may provide. }\end{array}$ & $\begin{array}{l}\text { 3.1.1 Source data are obtained from comprehensive } \\
\text { data collection programs that take into account } \\
\text { country-specific conditions. } \\
\text { 3.1.2 Source data reasonably approximate the } \\
\text { definitions, scope, classifications, valuation, and } \\
\text { time of recording required. } \\
\text { 3.1.3 Source data are timely. } \\
\text { 3.2.1 Source data-including censuses, sample } \\
\text { surveys, and administrative records-are routinely } \\
\text { assessed, e.g., for coverage, sample error, response } \\
\text { error, and nonsampling error; the results of the } \\
\text { assessments are monitored and made available to } \\
\text { guide statistical processes. } \\
\text { 3.3.1 Data compilation employs sound statistical } \\
\text { techniques to deal with data sources. } \\
\text { 3.3.2 Other statistical procedures (e.g., data } \\
\text { adjustments and transformations, and statistical } \\
\text { analysis) employ sound statistical techniques. } \\
\text { 3.4.1 Intermediate results are validated against other } \\
\text { information where applicable. } \\
\text { 3.4.2 Statistical discrepancies in intermediate data } \\
\text { are assessed and investigated. } \\
\text { 3.4.3 Statistical discrepancies and other potential } \\
\text { indicators or problems in statistical outputs are } \\
\text { investigated. } \\
\text { 3.5.1 Studies and analyses of revisions are carried } \\
\text { out routinely and used internally to inform statistical } \\
\text { processes (see also 4.3.3). }\end{array}$ \\
\hline
\end{tabular}




\begin{tabular}{|c|c|c|}
\hline Quality Dimensions & Elements & Indicators \\
\hline $\begin{array}{l}\text { 4. Serviceability } \\
\text { Statistics, with } \\
\text { adequate periodicity } \\
\text { and timeliness, are } \\
\text { consistent and } \\
\text { follow a predictable } \\
\text { revisions policy. }\end{array}$ & $\begin{array}{l}\text { 4.1 Periodicity and } \\
\text { timeliness-Periodicity and } \\
\text { timeliness follow internationally } \\
\text { accepted dissemination } \\
\text { standards. } \\
\text { 4.2 Consistency-Statistics are } \\
\text { consistent within the dataset, } \\
\text { over time, and with major } \\
\text { datasets. } \\
\text { 4.3 Revision policy and } \\
\text { practice-Data revisions follow } \\
\text { a regular and publicized } \\
\text { procedure. }\end{array}$ & $\begin{array}{l}\text { 4.2.1 Statistics are consistent within the dataset. } \\
\text { 4.2.2 Statistics are consistent or reconcilable over a } \\
\text { reasonable period of time. } \\
\text { 4.2.3 Statistics are consistent or reconcilable with } \\
\text { those obtained through other data sources and/or } \\
\text { statistical frameworks. } \\
\text { 4.3.1 Revisions follow a regular and transparent } \\
\text { schedule. } \\
\text { 4.3.2 Preliminary and/or revised data are clearly } \\
\text { identified. } \\
\text { 4.3.3 Studies and analyses of revisions are made } \\
\text { public (see also 3.5.1). }\end{array}$ \\
\hline $\begin{array}{l}\text { 5. Accessibility } \\
\text { Data and metadata } \\
\text { are easily available } \\
\text { and assistance to } \\
\text { users is adequate. }\end{array}$ & $\begin{array}{l}5.1 \text { Data accessibility- } \\
\text { Statistics are presented in a } \\
\text { clear and understandable } \\
\text { manner, forms of dissemination } \\
\text { are adequate, and statistics are } \\
\text { made available on an impartial } \\
\text { basis. }\end{array}$ & $\begin{array}{l}\text { 5.1.1 Statistics are presented in a way that facilitates } \\
\text { proper interpretation and meaningful comparisons } \\
\text { (layout and clarity of text, tables, and charts). } \\
\text { 5.1.2 Dissemination media and format are adequate. } \\
\text { 5.1.3 Statistics are released on a preannounced } \\
\text { schedule. } \\
\text { 5.1.4 Statistics are made available to all users at the } \\
\text { same time. } \\
\text { 5.1.5 Statistics not routinely disseminated are made } \\
\text { available upon request. } \\
\text { 5.2.1 Documentation on concepts, scope, } \\
\text { classifications, basis of recording, data sources, and } \\
\text { statistical techniques is available, and differences } \\
\text { from internationally accepted standards, guidelines, } \\
\text { or good practices are annotated. } \\
5.2 .2 \text { Levels of detail are adapted to the needs of the } \\
\text { intended audience. } \\
\text { 5.3.1 Contact points for each subject field are } \\
\text { publicized. } \\
\text { 5.3.2 Catalogs of publications, documents, and other } \\
\text { services, including information on any changes, are } \\
\text { widely available. }\end{array}$ \\
\hline
\end{tabular}




\section{Republic of Belarus-Users' Survey}

With the assistance of the Belarusian authorities and the IMF's Resident Representative in Minsk, a survey was conducted among users of macroeconomic and financial statistics. The survey asked users to evaluate a range of aspects of national accounts, prices (consumer price and producer price indices), fiscal, monetary, and balance of payments statistics. The survey complemented the mission's assessment of the quality of collection, compilation, and dissemination practices of official statistics. Users were asked to evaluate the coverage, periodicity, and timeliness of the datasets covered in the data ROSC assessment, as well as the dissemination practices of the compiling agencies.

Questionnaires were sent to 59 users and 37 responses (63 percent) were received from a broad range of users representing academia, government agencies, banks, and representative offices. Given the limited number of users that a ROSC mission can normally survey, the results of the questionnaire are used only as an "indication" of users' perception. In addition, since the size of sample is limited, some specific views or suggestions might have expressed by only a handful of respondents and might therefore not necessarily be representative. Nevertheless, the Users' Survey is a useful tool to alert authorities and the data ROSC mission of some underlying problems that might deserve more attention.

Table 7. Questionnaire Results Analyzed by Type of Users April 6, 2004

\begin{tabular}{lccc}
\hline \multicolumn{1}{c}{ Type of Respondent } & Total Sent & $\begin{array}{c}\text { Total } \\
\text { Received }\end{array}$ & $\begin{array}{c}\text { In Percent } \\
\text { Received }\end{array}$ \\
\hline Ministries and state agencies & 9 & 7 & 78 \\
Banks & 12 & 7 & 58 \\
Information and other agencies & 8 & 6 & 75 \\
Universities and institutes & 6 & 5 & 83 \\
Representatives offices & 5 & 3 & 60 \\
Embassies & 9 & 3 & 33 \\
Enterprises and non specify & 10 & 6 & 60 \\
Total & 59 & 37 & 63 \\
\hline
\end{tabular}


Questions No.

\section{Official statistics used}

\section{Sources of national official statistics}

\section{Descriptions of the} sources and methodologies used

4. Purposes for using official statistics

\subsection{Coverage}

\subsection{Level of detail}

\subsection{Periodicity}

6.2 Timeliness

7.1 Existence of calendar of release dates

7.2 Reliability of calendar of release dates
Analysis of Results

Official statistics are regularly used by two thirds of the respondents. Price statistics ( 81 percent) and monetary statistics (73 percent) are used the most, while the balance of payments (54 percent) is used the least.

Almost all users (95 percent) obtain statistics from official releases and publications; about 40 percent use private sector summaries and analysis.

Most users (89 percent) refer to official descriptions of the sources that compiled the statistics.

Official statistics are mostly used to describe general economic background (86 percent); a little over half of the respondents (57 percent) use official statistics for forecasting and econometric studies.

Over three quarters of the users are satisfied with the coverage of official statistics. Users are most satisfied with the coverage of balance of payment statistics (86 percent) and national accounts (82 percent); less than two thirds of the users (64 percent) are satisfied with the coverage of government finance statistics.

About 70 percent of users are satisfied with the general level of detail of official statistics. Users are most satisfied with the level of detail of the balance of payment statistics ( 82 percent) and the least with government finance statistics (55 percent).

Almost all users (94 percent) are satisfied with the frequency of compilation of official statistics. Respondents are most satisfied with the periodicity of national accounts (100 percent), and the least with price statistics ( 89 percent).

Close to 80 percent of respondents are satisfied with the timeliness of official statistics. Over 90 percent of users are satisfied with the timeliness of monetary statistics, while less than two thirds are satisfied with the timeliness of national accounts.

Over 55 percent of the respondents are aware of the existence of an advance release calendar (ARC). Two thirds of the users are aware of an ARC for national accounts, while less than half are aware of a calendar of government finance statistics.

About two thirds of users consider that data are usually released according to the release dates indicated in the ARC. Release dates for price statistics are considered the most reliable (74 percent of the respondents), while 53 percent of the users consider the release dates for the government finance statistics reliable. 
Questions No.

\subsection{Revision practices}

\subsection{Data access}

\subsection{Access to methodologies}

\subsection{Clarity of methodological information}

\subsection{Sources of official} statistics

\subsection{Methodological problems}

\subsection{Are official statistics unbiased and accurate? \\ 9.3 Quality of statistics compared to other countries}

9.4 Overall assessment
Analysis of Results

Less than half the users ( 45 percent) are satisfied with the information provided regarding the revisions to official statistics. Over half (53 percent) of users are satisfied with the information about revisions of national accounts, while only 35 percent of the users are satisfied with the information about revisions of government finance statistics.

Over three quarters of the users find official statistics easily accessible. Over 80 percent of respondents consider monetary and balance of payment statistics the most accessible, while about 60 percent of users find government finance statistics easily accessible.

60 percent of the users consider that access to metadata is easy.

70 percent of users consider access to metadata for monetary statistics to be easy, while 53 percent of users find it easy to get access to government finance statistics.

Less than half (45 percent) of the users consider that descriptions of methodological practices are not sufficiently clear and detailed.

About two thirds of users access official statistics in hard copy publications, one third in electronic form.

Close to three quarters of users consider the underlying methodology of official statistics sound and appropriate. Over 80 percent of users are satisfied with the methodology used for producing balance of payments statistics, while only 55 percent of users consider the methodology used for national accounts to be appropriate.

About 60 percent of the users consider official statistics to be unbiased and accurate. Over two thirds of respondents consider monetary and balance of payment statistics to be accurate, while only 42 percent of users consider national accounts statistics to be unbiased.

About 70 percent of users consider the quality of the Republic of Belarus's official statistics to be about the same as those of other countries in the region.

Users consider the overall quality of statistics to be slightly above average. Monetary statistics received the highest rating, while national accounts and government finance statistics received the lowest. 


\section{Survey of Data Users in the Republic of Belarus_-Summary}

Overall assessment. The respondents' views on the Republic of Belarus's statistics are mixed. Although three quarters of users consider the underlying methodology of official statistics sound and accurate, only 60 percent consider official statistics to be unbiased and accurate. Users are less satisfied with the quality of national accounts and government finance statistics, which received the lowest marks for almost all issues raised in the survey, while monetary and balance of payment statistics received the highest marks. Data users are mostly concerned with bringing national accounts methodology fully in line with international standards, improving the accuracy and reliability of government finance statistics, and establishing the revision policy of all national statistical institutions.

Prerequisites of quality. Users commented that major distortions in national accounts and production indices are caused by the need to meet targets for outputs, which probably lead to overstatements at the enterprise level.

Assurances of integrity. There is potential to improve the statistical staff's qualification in line with international professional principles and ethical standards. Users also complained that they do not receive advanced notice of major changes in methodology, source data, and statistical techniques.

Methodological soundness. Users expressed concern that official statistics are not fully in line with international standards and seem to be manipulated for political purposes. Some users were even more critical: they were of the opinion that it was very difficult to trust government statistics as institutions often tried to hide information by distributing meaningless data. According to users, frequent revisions of data indirectly indicate that some indicators are not reliable.

Accuracy and reliability. About half the users consider official statistics to be biased and inaccurate. While two thirds of respondents consider monetary and balance of payment statistics to be accurate, only 40 percent of users consider national accounts to be unbiased.

Serviceability. Users were generally positive about the periodicity and timeliness of data dissemination. However, they desired shorter timeliness for national accounts and balance of payments. Concerns were also expressed about the consistency of some data sets (national accounts, government finance statistics, and monetary statistics). Revision policy was criticized for its lack of transparency; access to revised data is also considered difficult.

Accessibility. Users commented about difficulties in accessing data for national accounts and prices, and metadata for national accounts and government finance statistics. They also expressed dissatisfaction with the fact that the NBRB is currently disseminating balance of payment statistics only in hard copy instead of posting it on its web site (as in 2002). In general, users consider it difficult to get access to metadata. 
The following tables summarize users' responses to the survey:

Table 8a. Republic of Belarus: Results of Users' Survey

\begin{tabular}{|c|c|c|c|c|c|c|c|c|c|}
\hline & 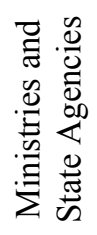 & $\begin{array}{l}\frac{n}{\tilde{E}} \\
\stackrel{\tilde{D}}{E}\end{array}$ & 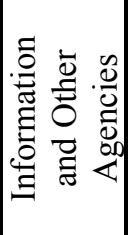 & 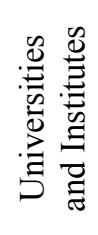 & 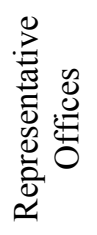 & 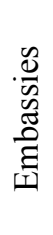 & 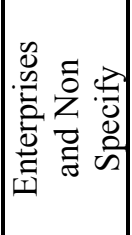 & $\stackrel{\pi}{0}$ & 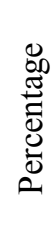 \\
\hline Questionnaires sent out & 9 & 12 & 8 & 6 & 5 & 9 & 10 & 59 & \\
\hline Responses (excl. not applicable) & 7 & 7 & 6 & 5 & 3 & 3 & 6 & 37 & 63 \\
\hline \multicolumn{10}{|c|}{ Uses of Official Macroeconomic Statistics } \\
\hline \multicolumn{10}{|l|}{$\begin{array}{l}\text { 1. Which macroeconomic statistics } \\
\text { are you using regularly? }\end{array}$} \\
\hline -National Accounts & 3 & 4 & 5 & 5 & 3 & 2 & 2 & 24 & 65 \\
\hline -Prices & 4 & 5 & 6 & 5 & 3 & 3 & 4 & 30 & 81 \\
\hline -Government Finance Statistics & 4 & 4 & 6 & 3 & 2 & 3 & 2 & 24 & 65 \\
\hline -Monetary and Financial Statistics & 4 & 7 & 6 & 2 & 3 & 3 & 2 & 27 & 73 \\
\hline $\begin{array}{l}\text {-Balance of Payments } \\
\text {-Other }\end{array}$ & 2 & 6 & 5 & 2 & 2 & 1 & 2 & 20 & 54 \\
\hline production indices & 4 & 3 & 6 & 5 & 3 & 1 & 4 & 26 & 70 \\
\hline labor market & 4 & 4 & 2 & 3 & 3 & 3 & 2 & 21 & 57 \\
\hline merchandise trade & 6 & 4 & 6 & 4 & 2 & 2 & 4 & 28 & 76 \\
\hline $\begin{array}{l}\text { international reserves and } \\
\text { foreign liquidity }\end{array}$ & 2 & 5 & 5 & 0 & 1 & 2 & 1 & 16 & 43 \\
\hline external debt & 2 & 5 & 5 & 1 & 2 & 3 & 1 & 19 & 51 \\
\hline $\begin{array}{l}\text { international investment } \\
\text { position }\end{array}$ & 3 & 5 & 6 & 2 & 1 & 2 & 1 & 20 & 54 \\
\hline other & 3 & 1 & 1 & 0 & 1 & 1 & 0 & 7 & 19 \\
\hline \multicolumn{10}{|l|}{$\begin{array}{l}\text { 2. Where do you obtain the official } \\
\text { statistics? }\end{array}$} \\
\hline $\begin{array}{l}\text {-Official press releases and } \\
\text { publications }\end{array}$ & 7 & 7 & 6 & 4 & 3 & 3 & 5 & 35 & 95 \\
\hline $\begin{array}{l}\text {-Private sector summaries and } \\
\text { analyses }\end{array}$ & 2 & 4 & 2 & 1 & 3 & 2 & 1 & 15 & 41 \\
\hline -Official policy papers & 6 & 7 & 6 & 5 & 2 & 1 & 6 & 33 & 89 \\
\hline $\begin{array}{l}\text {-Publications from international } \\
\text { organizations }\end{array}$ & 3 & 5 & 4 & 4 & 3 & 2 & 3 & 24 & 65 \\
\hline -Other Sources & 4 & 4 & 1 & 0 & 2 & 0 & 0 & 11 & 30 \\
\hline \multicolumn{10}{|l|}{$\begin{array}{l}\text { 3. Do you refer to official } \\
\text { descriptions of the sources and } \\
\text { methods that were used to compile } \\
\text { the official statistics? }\end{array}$} \\
\hline -Yes & 5 & 5 & 6 & 5 & 3 & 2 & 5 & 31 & 89 \\
\hline -No & 1 & 2 & 0 & 0 & 0 & 1 & 0 & 4 & 11 \\
\hline
\end{tabular}


Table 8a. Republic of Belarus: Results of Users' Survey

\begin{tabular}{|c|c|c|c|c|c|c|c|c|c|}
\hline & 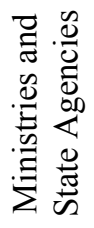 & $\begin{array}{l}\frac{n}{\tilde{E}} \\
\text { Ф્ }\end{array}$ & 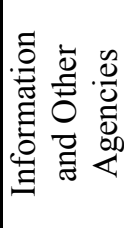 & 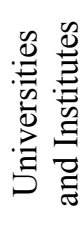 & 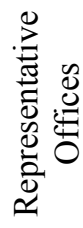 & 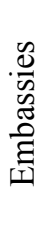 & 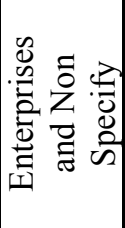 & 㫼 & 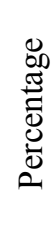 \\
\hline \multicolumn{10}{|l|}{$\begin{array}{l}\text { 4. For what purposes do you use the } \\
\text { official statistics? }\end{array}$} \\
\hline $\begin{array}{l}\text {-Analysis of current developments } \\
\text { for short-term decision making }\end{array}$ & 6 & 6 & 5 & 1 & 1 & 2 & 4 & 25 & 68 \\
\hline $\begin{array}{l}\text {-Analysis of trends for longer- } \\
\text { term policy formulation }\end{array}$ & 5 & 5 & 5 & 3 & 1 & 1 & 5 & 25 & 68 \\
\hline $\begin{array}{l}\text {-Econometric model building and } \\
\text { forecasting }\end{array}$ & 5 & 4 & 5 & 3 & 1 & 0 & 3 & 21 & 57 \\
\hline -Economic research & 1 & 4 & 6 & 5 & 2 & 1 & 5 & 24 & 65 \\
\hline $\begin{array}{l}\text {-Comparison with economic } \\
\text { developments in other countries }\end{array}$ & 4 & 3 & 5 & 5 & 2 & 1 & 4 & 24 & 65 \\
\hline -General economic background & 7 & 6 & 6 & 3 & 2 & 3 & 5 & 32 & 86 \\
\hline - Other sources & 2 & 4 & 0 & 1 & 2 & 0 & 0 & 9 & 24 \\
\hline
\end{tabular}

Table 8b. Republic of Belarus: Results of Users' Survey

\begin{tabular}{|l|c|c|c|c|}
\hline & \multicolumn{3}{|c|}{ Total } & \multicolumn{2}{c|}{ Percentage } \\
\cline { 2 - 5 } & Yes & No & Yes & No \\
\hline 5.1 Is the coverage of these statistics satisfactory? & 89 & 27 & 77 & 23 \\
- National Accounts & 18 & 4 & 82 & 18 \\
-Prices & 18 & 7 & 72 & 28 \\
- Government Finance & 14 & 8 & 64 & 36 \\
- Monetary Statistics & 20 & 5 & 80 & 20 \\
- Balance of Payments & 19 & 3 & 86 & 14 \\
\hline 5.2 Is the level of detail provided by these statistics & 82 & 37 & 69 & 31 \\
satisfactory? & & & & \\
- National Accounts & 14 & 10 & 58 & 42 \\
-Prices & 19 & 7 & 73 & 27 \\
- Government Finance & 12 & 10 & 55 & 45 \\
- Monetary Statistics & 19 & 6 & 76 & 24 \\
- Balance of Payments & 18 & 4 & 82 & 18 \\
\hline 6.1 Is the frequency (e.g. weekly, monthly, quarterly annual & 109 & 7 & 94 & 6 \\
compilation) of these statistics satisfactory? & & & & \\
- National Accounts & 26 & 0 & 100 & 0 \\
-Prices & 24 & 3 & 89 & 11 \\
-Monetary Statistics & 18 & 2 & 90 & 10 \\
-Monetary Statistics & 21 & 1 & 95 & 5 \\
- Balance of Payments & 20 & 1 & 95 & 5 \\
\hline
\end{tabular}


Table 8b. Republic of Belarus: Results of Users' Survey

\begin{tabular}{|c|c|c|c|c|}
\hline & \multicolumn{2}{|c|}{ Total } & \multicolumn{2}{|c|}{ Percentage } \\
\hline & Yes & No & Yes & No \\
\hline $\begin{array}{l}\text { 6.2 Is the timeliness (the delay of publication) of these } \\
\text { statistics satisfactory? } \\
\text { - National Accounts } \\
\text {-Prices } \\
\text {-Government Finance } \\
\text {-Monetary Statistics } \\
\text { - Balance of Payments }\end{array}$ & $\begin{array}{l}86 \\
14 \\
20 \\
16 \\
21 \\
15\end{array}$ & $\begin{array}{l}24 \\
8 \\
5 \\
5 \\
2 \\
4\end{array}$ & $\begin{array}{l}78 \\
64 \\
80 \\
76 \\
91 \\
79\end{array}$ & $\begin{array}{c}36 \\
20 \\
24 \\
9 \\
21\end{array}$ \\
\hline $\begin{array}{l}\text { 7.1 Do you know if there is a publicly disseminated calendar } \\
\text { that announces the dissemination of the various official } \\
\text { statistics? } \\
\text { - National Accounts } \\
\text {-Prices } \\
\text { - Government Finance } \\
\text { - Monetary Statistics } \\
\text { - Balance of Payments }\end{array}$ & $\begin{array}{c}14 \\
13 \\
10 \\
15 \\
0\end{array}$ & $\begin{array}{c} \\
7 \\
11 \\
11 \\
10 \\
12\end{array}$ & $\begin{array}{c}67 \\
54 \\
48 \\
60 \\
0\end{array}$ & $\begin{array}{c}33 \\
46 \\
52 \\
40 \\
100\end{array}$ \\
\hline $\begin{array}{l}\text { 7.2 If there is a calendar of release dates, are the official } \\
\text { statistics released on the dates announced? } \\
\text {-National Accounts } \\
\text {-Prices } \\
\text { - Government Finance } \\
\text {-Monetary Statistics } \\
\text {-Balance of Payments }\end{array}$ & $\begin{array}{c}55 \\
12 \\
14 \\
8 \\
12 \\
9\end{array}$ & $\begin{array}{l}29 \\
5 \\
5 \\
7 \\
5 \\
7\end{array}$ & $\begin{array}{l}65 \\
71 \\
74 \\
53 \\
71 \\
56\end{array}$ & $\begin{array}{l}29 \\
26 \\
47 \\
29 \\
44\end{array}$ \\
\hline $\begin{array}{l}\text { 7.3 Is there enough information about revisions to official } \\
\text { statistics to satisfy your needs? } \\
\text { - National Accounts } \\
\text {-Prices } \\
\text {-Government Finance } \\
\text {-Monetary Statistics } \\
\text { - Balance of Payments }\end{array}$ & $\begin{array}{l}41 \\
9 \\
9 \\
6 \\
9 \\
8\end{array}$ & $\begin{array}{c}50 \\
8 \\
11 \\
11 \\
10 \\
10\end{array}$ & $\begin{array}{l}45 \\
53 \\
45 \\
35 \\
47 \\
44\end{array}$ & $\begin{array}{l}55 \\
47 \\
55 \\
65 \\
53 \\
56\end{array}$ \\
\hline $\begin{array}{l}\text { 8.1 Are the official statistics referred in item } 1 \text { easily } \\
\text { accessible to you? } \\
\text { - National Accounts } \\
\text { - Prices } \\
\text {-Government Finance } \\
\text { - Monetary Statistics } \\
\text { - Balance of Payments } \\
\end{array}$ & $\begin{array}{l}93 \\
19 \\
22 \\
14 \\
21 \\
17\end{array}$ & $\begin{array}{l}29 \\
5 \\
5 \\
9 \\
4 \\
6 \\
\end{array}$ & $\begin{array}{l}79 \\
81 \\
61 \\
84 \\
74 \\
\end{array}$ & $\begin{array}{l}21 \\
19 \\
39 \\
16 \\
26 \\
\end{array}$ \\
\hline $\begin{array}{l}\text { 8.2 Can you get easy access to information pertaining to } \\
\text { official statistics you use (explanatory notes, methodological } \\
\text { descriptions)? } \\
\text {-National Accounts } \\
\text {-Prices } \\
\text { - Government Finance } \\
\text {-Monetary Statistics } \\
\text {-Balance of Payments }\end{array}$ & $\begin{array}{l}14 \\
14 \\
10 \\
16 \\
11\end{array}$ & $\begin{array}{c}43 \\
\\
8 \\
10 \\
9 \\
7 \\
9\end{array}$ & $\begin{array}{l}64 \\
58 \\
53 \\
70 \\
55\end{array}$ & $\begin{array}{l}36 \\
42 \\
47 \\
30 \\
45\end{array}$ \\
\hline
\end{tabular}


Table 8b. Republic of Belarus: Results of Users' Survey

\begin{tabular}{|l|c|c|c|c|}
\hline & \multicolumn{2}{|c|}{ Total } & \multicolumn{2}{c|}{ Percentage } \\
\cline { 2 - 4 } & Yes & No & Yes & No \\
\hline 9.1 Is the underlying methodology of official statistics sound & 51 & 37 & 58 & 42 \\
and appropriate? & & & & \\
- National Accounts & 11 & 9 & 55 & 45 \\
-Prices & 13 & 6 & 68 & 32 \\
-Government Finance & 11 & 3 & 79 & 21 \\
- Monetary Statistics & 16 & 4 & 80 & 20 \\
- Balance of Payments & 0 & 15 & 0 & 100 \\
\hline 9.2 Do you consider the official statistics to be unbiased and & 58 & 41 & 59 & 41 \\
accurate? & & & & \\
- National Accounts & 8 & 11 & 42 & 58 \\
-Prices & 10 & 10 & 50 & 50 \\
-Government Finance & 10 & 7 & 59 & 41 \\
-Monetary Statistics & 16 & 6 & 73 & 27 \\
- Balance of Payments & 14 & 7 & 67 & 33 \\
\hline
\end{tabular}

Table 8c. Republic of Belarus: Results of Users' Survey

\begin{tabular}{|c|c|c|}
\hline & Total & Percentage \\
\hline $\begin{array}{l}8.3 \text { Is the above information on methodology clear and } \\
\text { adequate? } \\
\text {-Yes } \\
\text {-No } \\
\text {-No opinion }\end{array}$ & $\begin{array}{c}11 \\
13 \\
5\end{array}$ & $\begin{array}{l}38 \\
45 \\
17\end{array}$ \\
\hline $\begin{array}{l}\text { 8.4 How do you get access to official statistics? } \\
\text { - Hard copy (official releases, hard copy publications, and } \\
\text { data specifically requested) } \\
\text { - Electronic form (official web site, email requests, and } \\
\text { others) }\end{array}$ & $\begin{array}{l}87 \\
47\end{array}$ & $\begin{array}{l}65 \\
35\end{array}$ \\
\hline
\end{tabular}


Table 8d. Republic of Belarus: Results of Users' Survey

\begin{tabular}{|l|c|c|c|c|c|c|}
\hline & \multicolumn{3}{|c|}{ Total } & \multicolumn{4}{c|}{ Percentage } \\
\cline { 2 - 7 } & Better & -Same & -Worse & Better & Same & Worse \\
\hline 9.3 How do you compare the quality of the country with & 15 & 67 & 13 & 16 & 71 & 14 \\
those of other countries in the region? & & & & & & \\
- National Accounts & 2 & 13 & 3 & 11 & 72 & 17 \\
-Prices & 3 & 14 & 4 & 14 & 67 & 19 \\
-Government Finance & 2 & 12 & 3 & 12 & 71 & 18 \\
- Monetary Statistics & 4 & 14 & 2 & 20 & 70 & 10 \\
-Balance of Payments & 4 & 14 & 1 & 21 & 74 & 5 \\
\hline
\end{tabular}

Table 8e. Republic of Belarus: Results of Users' Survey

\begin{tabular}{|c|c|c|c|c|c|}
\hline & \multicolumn{5}{|c|}{ Rating } \\
\hline & 1 & 2 & 3 & 4 & 5 \\
\hline $\begin{array}{l}\text { 9.4 How do you assess the overall quality of the official } \\
\text { statistics? (1 rated as poor and } 5 \text { as excellent) } \\
\text { - National Accounts } \\
\text {-Prices } \\
\text { - Government Finance } \\
\text {-Monetary Statistics } \\
\text {-Balance of Payments }\end{array}$ & $\begin{array}{l}1 \\
0 \\
1 \\
0 \\
0 \\
0\end{array}$ & $\begin{array}{l}17 \\
7 \\
3 \\
5 \\
1 \\
1\end{array}$ & $\begin{array}{l}27 \\
5 \\
8 \\
5 \\
4 \\
4\end{array}$ & $\begin{array}{c}54 \\
8 \\
12 \\
9 \\
13 \\
13\end{array}$ & $\begin{array}{l}3 \\
2 \\
2 \\
5 \\
5\end{array}$ \\
\hline & \multicolumn{5}{|c|}{ Percentage } \\
\hline & 1 & 2 & 3 & 4 & 5 \\
\hline $\begin{array}{l}\text { 9.4 How do you assess the overall quality of the official } \\
\text { statistics? (1 rated as poor and } 5 \text { as excellent) } \\
\text { - National Accounts } \\
\text {-Prices } \\
\text { - Government Finance } \\
\text { - Monetary Statistics } \\
\text {-Balance of Payments }\end{array}$ & $\begin{array}{l}0.0 \\
3.8 \\
0.0 \\
0.0 \\
0.0\end{array}$ & $\begin{array}{c}14.9 \\
30.4 \\
11.5 \\
23.8 \\
4.3 \\
4.8\end{array}$ & $\begin{array}{l}21.7 \\
30.8 \\
23.8 \\
17.4 \\
23.8\end{array}$ & $\begin{array}{l}47.4 \\
34.8 \\
46.2 \\
42.9 \\
56.5 \\
57.1\end{array}$ & $\begin{array}{c}13.0 \\
7.7 \\
9.5 \\
21.7 \\
14.3\end{array}$ \\
\hline
\end{tabular}




\section{Questionnaire for Users of Official Macroeconomic Statistics}

\section{Section A: General information about users of official macroeconomic statistics of (insert name} of country)

1. Which official statistics do you use regularly?

(please check off all relevant datasets)

1.1 National accounts (NA)

1.2 Prices

1.3 Government finance statistics (GFS)

1.4 Monetary and financial statistics (Monetary)

1.5 Balance of payments

1.6 Other:

Production indices

Labor market

Merchandise trade

International reserves and foreign liquidity

External debt

International investment position

Other sources (please specify)

2. Where do you obtain the national official statistics?

(please check off all relevant sources)

2.1 Official press releases and publications on macroeconomic statistics

2.2 Private sector summaries and analyses

2.3 Official policy papers

Publications from international organizations about the country

Other sources (please specify)

3. Do you refer to official descriptions of the sources and methods that were used to compile the official statistics?

$$
\text { Yes } \square
$$

No

(please comment) 
4. For what purposes do you use the official statistics?

\section{(please check off all relevant uses)}

4.1 Analysis of current developments for short-term decision making

4.2 Analysis of trends for longer-term policy formulation

4.3 Econometric model building and forecasting

4.4 Economic research

4.5 Comparison with economic developments in other countries

4.6 General economic background

4.7 Other (please specify)

Section B: Information concerning quality aspects of the national official macroeconomic statistics

5. Coverage and detail

5.1 In general, are you satisfied with the coverage of official statistics?

\begin{tabular}{|c|c|c|c|c|c|c|}
\cline { 2 - 6 } \multicolumn{1}{c|}{} & NA & Prices & GFS & Monetary & $\begin{array}{c}\text { Balance } \\
\text { of } \\
\text { Payments }\end{array}$ & $\begin{array}{c}\text { Other } \\
\text { (specify) }\end{array}$ \\
\hline Yes & & & & & & \\
\hline No & & & & & & \\
\hline
\end{tabular}

(Please comment)

5.2 In general, are you satisfied with the official statistics in terms of their level of detail?

\begin{tabular}{|l|l|l|l|l|l|l|}
\cline { 2 - 6 } \multicolumn{1}{c|}{} & NA & Prices & GFS & Monetary & $\begin{array}{c}\text { Balance } \\
\text { of } \\
\text { Payments }\end{array}$ & $\begin{array}{c}\text { Other } \\
\text { (specify) }\end{array}$ \\
\hline Yes & & & & & & \\
\hline No & & & & & & \\
\hline
\end{tabular}

(Please comment) 
6. Periodicity and timeliness

6.1 Are you satisfied with the frequency of compilation of the official statistics (e.g., weekly, monthly, quarterly, annual)?

\begin{tabular}{|c|c|c|c|c|c|c|}
\cline { 2 - 7 } \multicolumn{1}{c|}{} & NA & Prices & GFS & Monetary & $\begin{array}{c}\text { Balance } \\
\text { of } \\
\text { Payments }\end{array}$ & $\begin{array}{c}\text { Other } \\
\text { (specify) }\end{array}$ \\
\hline Yes & & & & & & \\
\hline No & & & & & & \\
\hline
\end{tabular}

(Please comment)

6.2 In general, do you consider that the official statistics are disseminated with the appropriate timeliness (the time lag after the period to which they pertain, e.g., 60 days after the reference period)?

\begin{tabular}{|c|c|c|c|c|c|c|}
\cline { 2 - 6 } \multicolumn{1}{c|}{} & NA & Prices & GFS & Monetary & $\begin{array}{c}\text { Balance } \\
\text { of } \\
\text { Payments }\end{array}$ & $\begin{array}{c}\text { Other } \\
\text { (specify) }\end{array}$ \\
\hline Yes & & & & & & \\
\hline No & & & & & & \\
\hline
\end{tabular}

(Please comment)

7. Other dissemination practices

7.1 Do you know if there is a publicly disseminated calendar that announces in advance the dates on which the various official statistics will be disseminated?

\begin{tabular}{|c|c|c|c|c|c|c|}
\cline { 2 - 6 } \multicolumn{1}{c|}{} & NA & Prices & GFS & Monetary & $\begin{array}{c}\text { Balance } \\
\text { of } \\
\text { Payments }\end{array}$ & $\begin{array}{c}\text { Other } \\
\text { (specify) }\end{array}$ \\
\hline Yes & & & & & & \\
\hline No & & & & & & \\
\hline
\end{tabular}


7.2 If there is a calendar of release dates, in your experience, are the official statistics released on the dates announced?

\begin{tabular}{|l|l|l|l|l|l|c|}
\cline { 2 - 6 } \multicolumn{1}{c|}{} & NA & Prices & GFS & Monetary & $\begin{array}{c}\text { Balance of } \\
\text { Payments }\end{array}$ & $\begin{array}{c}\text { Other } \\
\text { (specify) }\end{array}$ \\
\hline Yes & & & & & & \\
\hline No & & & & & & \\
\hline
\end{tabular}

7.3 Is there enough information about revisions to official statistics to satisfy your needs?

\begin{tabular}{|l|l|l|l|l|l|c|}
\cline { 2 - 6 } \multicolumn{1}{c|}{} & NA & Prices & GFS & Monetary & $\begin{array}{c}\text { Balance of } \\
\text { Payments }\end{array}$ & $\begin{array}{c}\text { Other } \\
\text { (specify) }\end{array}$ \\
\hline Yes & & & & & & \\
\hline No & & & & & & \\
\hline
\end{tabular}

(Please comment)

8. Accessibility

8.1 Can you easily access the following official statistics?

\begin{tabular}{|l|l|l|l|l|l|l|}
\cline { 2 - 7 } \multicolumn{1}{c|}{} & NA & Prices & GFS & Monetary & $\begin{array}{c}\text { Balance } \\
\text { of } \\
\text { Payments }\end{array}$ & $\begin{array}{c}\text { Other } \\
\text { (specify) }\end{array}$ \\
\hline Yes & & & & & & \\
\hline No & & & & & & \\
\hline
\end{tabular}

(Please comment)

8.2 Can you easily access information pertaining to official statistics you use (explanatory notes, methodological descriptions, references concerning concepts, classifications, statistical practice)?

\begin{tabular}{|l|l|l|l|l|l|l|}
\cline { 2 - 7 } \multicolumn{1}{c|}{} & NA & Prices & GFS & Monetary & $\begin{array}{c}\text { Balance } \\
\text { of } \\
\text { Payments }\end{array}$ & $\begin{array}{c}\text { Other } \\
\text { (specify) }\end{array}$ \\
\hline Yes & & & & & & \\
\hline No & & & & & & \\
\hline
\end{tabular}

(Please comment) 
8.3 Is the above information on methodology sufficiently clear and at an adequate level of detail to be useful to you?

$$
\text { Yes } \square \text { No }
$$

No opinion

8.4 How do you get access to official statistics?

(Please check off all relevant formats)

Hard copy

Official releases

Hard copy publications

Data specifically requested

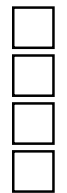

Electronic form

Official web site

Other

E-mail requests

(If obtained in other formats, please comment)

9. Overall assessment

9.1 In your opinion, is the underlying methodology of official statistics sound and appropriate?

\begin{tabular}{|l|l|l|l|l|l|l|}
\cline { 2 - 7 } \multicolumn{1}{c|}{} & NA & Prices & GFS & Monetary & $\begin{array}{c}\text { Balance } \\
\text { of } \\
\text { Payments }\end{array}$ & $\begin{array}{c}\text { Other } \\
\text { (specify) }\end{array}$ \\
\hline Yes & & & & & & \\
\hline No & & & & & & \\
\hline
\end{tabular}

(if no,

Please comment)

9.2 In general, do you consider the official statistics to be unbiased and accurate?

\begin{tabular}{|l|l|l|l|l|l|l|}
\cline { 2 - 7 } \multicolumn{1}{c|}{} & NA & Prices & GFS & Monetary & $\begin{array}{c}\text { Balance } \\
\text { of } \\
\text { Payments }\end{array}$ & $\begin{array}{c}\text { Other } \\
\text { (specify) }\end{array}$ \\
\hline Yes & & & & & & \\
\hline No & & & & & & \\
\hline
\end{tabular}

(Please comment) 
9.3 How would you compare the quality of official statistics of the country with those of other countries in the region?

\begin{tabular}{|l|l|l|l|l|l|l|}
\cline { 2 - 7 } \multicolumn{1}{c|}{} & NA & Prices & GFS & Monetary & $\begin{array}{c}\text { Balance } \\
\text { of } \\
\text { Payments }\end{array}$ & $\begin{array}{c}\text { Other } \\
\text { (specify) }\end{array}$ \\
\hline Better & & & & & & \\
\hline Same & & & & & & \\
\hline Worse & & & & & & \\
\hline
\end{tabular}

(please comment):

9.4 How do you assess the overall quality of the official statistics? (Please rate on a scale from 1-5 the overall quality of statistics for your country, with 1 rated as poor and 5 as excellent)

\begin{tabular}{|c|c|c|c|c|c|}
\hline NA & Prices & GFS & Monetary & $\begin{array}{c}\text { Balance of } \\
\text { Payments }\end{array}$ & $\begin{array}{c}\text { Other } \\
\text { (specify) }\end{array}$ \\
\hline & & & & & \\
\hline
\end{tabular}

10. Additional comments, including areas where you see room for improvement (please specify the dataset(s) to which your comments refer)

Name (optional)

Position or title

Name of organization

Tel. Fax Email address

Thank you for your assistance in completing this questionnaire. 